
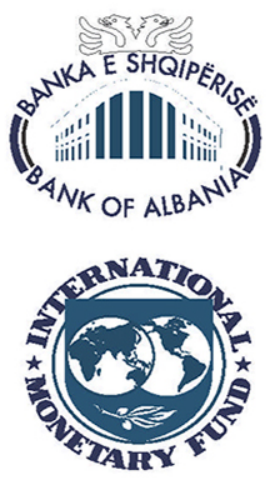

\title{
NEGATIVE EURO AREA INTEREST RATES AND SPILLOVERS ON WESTERN BALKAN CENTRAL BANK POLICIES AND INSTRUMENTS
}

Proceedings of the conference co-hosted by the Bank of Albania and International Monetary Fund (IMF). Tirana on May 4-5, 2017 Edited by: Guido Della Valle, Erald Themeli, Romain Veyrune 


\author{
Bank of Albania \\ International Monetary Fund
}

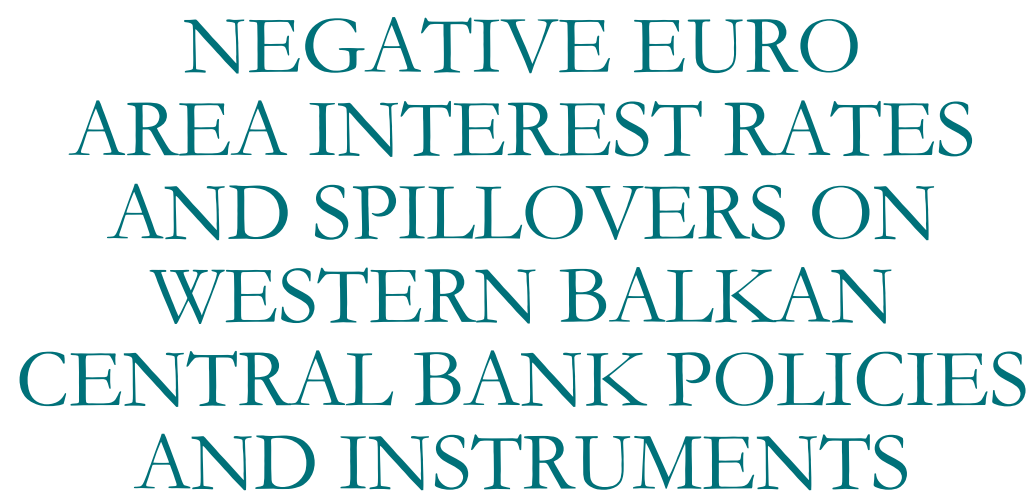

The book represents the proceedings of the conference co-bosted by the Bank of Albania and the International Monetary Fund (IMF), in Tirana on May 4-5, 2017. The conference was organized with the financial support of Switzerland.

Edited by: Guido Della Valle, Erald Themeli, Romain Veyrune 
Published by:

(C) Bank of Albania

Address: Sheshi "Skënderbej", Nr.1, Tirana, Albania

Tel.: $\quad+35542419301 / 2 / 3 ;+35542419401 / 2 / 3$

Fax: $\quad+35542419408$

E-mail: publi@bankofalbania.org

Reproduction is permitted provided that the source is acknowledged.

Printed in: 300 copies

Printed by:

ISBN 978-9928-4453-9-1

The views expressed herein are of the authors and do not necessarily reflect those of the International Monetary Fund or Bank of Albania

The organizers of the conference would like to express gratitude to Switzerland for the financial support provided and Enri Herri of Bank of Albania and Anna Vlassova of the International Monetary Fund for the invaluable logistical support provided for the organization of the conference. 


\section{CONTENTS}

INTRODUCTION

Guido Della V alle, Erald Themeli, Romain Veyrune

CONFERENCE AGENDA

WELCOME ADDRESSES

$\underline{23}$

Gent Sejko, Bank of Albania, Governor $\underline{25}$

Christoph Graf, Ambassador of Switzerland in Albania

Miguel Savastano, International Monetary Fund,

Monetary and Capital Markets Department, Deputy Director

$\underline{35}$

FIRST SESSION:

NEGATIVE EURO AREA INTEREST RATES AND

$\underline{39}$

FINANCIAL STABILITY: A FIRST LOOK BEYOND THE WESTERN BALKANS AND GENERAL TRENDS

Moderator: Klodion Shehu, Bank of Albania, Financial Stability Department,

Director

HOW DO INTEREST RATE DIFFERENTIALS IMPACT ON EUROIZATION? EVIDENCE FROM THE

OENB EURO SURVEY

Thomas Scheiber and Julia Woers, Oesterreichische Nationalbank,

Foreign Research Division

NEGATIVE EURO AREA INTEREST RATES AND

EFFECTIVE DE-EUROIZATION STRATEGY

Romain Veyrune, International Monetary Fund, Senior Economist 
SECOND SESSION:

NEGATIVE EURO AREA INTEREST RATES AND

FINANCIAL STABILITY IN WESTERN

BALKAN ECONOMIES

Moderator: Natasha Abmetaj, Bank of Albania, Second Deputy Governor

INTRODUCTORY REMARKS: PANEL ON "NEGATIVE EURO AREA INTEREST RATES AND FINANCIAL STABILITY IN WESTERN BALKAN ECONOMIES"

Natasha Abmetaj, Bank of Albania, Second Deputy Governor

IMPLICATIONS OF LOW INTEREST RATES FOR FINANCIAL STABILITY IN ALBANIA

Klodion Shebu, Bank of Albania, Financial Stability Department, Director

WHAT IS OBSCURED BY AGGREGATE DATA IN THE CASE OF BOSNIA AND HERZEGOVINA?

Belma Colaković, Central Bank of Bosnia and Herzegovina, Chief Economist

FINANCIAL STABILITY UNDER UNILATERAL

EUROIZATION: THE CASE OF KOSOVO

Arben Mustafa, Central Bank of the Republic of Kosovo, Advisor to the Governor

ECB NON-STANDARD MONETARY POLICY MEASURES

AND FINANCIAL STABILITY IN WESTERN BALKAN

ECONOMIES WITH EMPHASIS ON THE MONTENEGRO CASE 107

Milena V ucinic, Central Bank of Montenegro, Department for Financial Stability,

Research and Statistics

THIRD SESSION:

NEGATIVE EURO AREA INTEREST RATES AND

RESERVE MANAGEMENT

Moderator: Elisabeta Gjoni, Bank of Albania, First Deputy Governor

INTRODUCTORY REMARKS: PANEL ON "NEGATIVE EURO

AREA INTEREST RATES AND RESERVE MANAGEMENT"

Elisabeta Gjoni, Bank of Albania, First Deputy Governor

ARE YOU PREPARED TO ASSUME THE RISK OF INCREASING EURO YIELDS?

Roberto de Beaufort Camargo, World Bank, Lead Financial Officer

NEGATIVE EURO AREA INTEREST RATES AND RESERVE

MANAGEMENT AT THE CENTRAL BANK OF ROMANIA
Victor Andrei, National Bank of Romania, Market Operations Department, Director 
IMPLEMENTATION OF THE NEW FX RESERVES INVESTMENT STRATEGY AT THE CENTRAL BANK OF HUNGARY

Sandor Ladányi, Magyar Nemzeti Bank, Foreign Exchange Reserves Management, Strategy Department

FOURTH SESSION:

NEGATIVE EURO AREA INTEREST RATES AND

RESERVE MANAGEMENT (CONTINUED)

Moderator: Roberto de Beaufort Camargo, World Bank, Lead Financial Officer

NEGATIVE EURO AREA INTEREST RATES AND SPILLOVERS ON WESTERN BALKAN CENTRAL BANK POLICIES AND INSTRUMENTS

Marian Gjermeni, Bank of Albania, Monetary Operations Department, Director

FX RESERVE MANAGEMENT IN A NEGATIVE INTEREST RATES ENVIRONMENT: THE MACEDONIAN EXPERIENCE

Vesna Hristovska, National Bank of the Republic of Macedonia,

Financial Market Operations Department

FIFTH SESSION:

NEGATIVE EURO AREA INTEREST RATES AND MONETARY POLICY IN THE PROXIMITY OF THE EURO AREA

Moderator: Guido Della V alle, International Monetary Fund, Monetary Policy

Advisor

INTRODUCTORY REMARKS: PANEL ON "NEGATIVE EURO AREA INTEREST RATES AND MONETARY POLICY IN THE PROXIMITY OF THE EURO AREA"

Guido Della V alle, International Monetary Fund, Monetary Policy Advisor

MONETARY POLICY IN THE PROXIMITY OF THE EURO AREA: WHAT CHANGES WITH NEGATIVE EURO AREA RATES? 203 Ryan Banerjee, Bank for International Settlement, Senior Economist

MONETARY POLICY BELOW THE ZERO LOWER BOUND Ulrich Bindseil, European Central Bank, Market Operations, Director General

MONETARY POLICY BELOW THE ZERO LOWER BOUND Thomas Moser, Swiss National Bank, Alternate Member of the Governing Board

MONETARY POLICY AND EXCHANGE RATE COMMITMENT

IN THE CZECH REPUBLIC

Dana Hajkova, Czech National Bank, Advisor to the Bank Board 
NON-STANDARD MONETARY POLICY IN A LOW INTEREST

RATE ENVIRONMENT

$\underline{255}$

Daniel Felcser, Magyar Nemzeti Bank, Monetary Strategy Department,

Senior Economic Analyst

SIXTH SESSION:

NEGATIVE EURO AREA INTEREST RATES AND

265

MONETARY POLICY IN THE WESTERN BALKANS

Moderator: Erald Themeli, Bank of Albania, Monetary Policy Department, Director

SPILLOVERS OF THE ECB'S NON-STANDARD MONETARY

POLICY MEASURES ON SOUTHEASTERN EUROPE

$\underline{267}$

Keynote address: Isabella Moder, European Central Bank, Economist

ESTIMATING THE LOWER POLICY RATE BOUND IN A

EUROIZED ECONOMY

Guido Della Valle, International Monetary Fund, Monetary Policy Advisor

IMPLICATIONS FROM THE LOOSE ECB MONETARY POLICY

FOR THE REGION (FOCUS ON MACEDONIA)

$\underline{289}$

Anita Angelouska Bezhoska, National Bank of the Republic of Macedonia, Vice Governor

CONDUCT OF MONETARY POLICY WITH FINANCIAL STABILITY ISSUES AND A CHALLENGING ENVIRONMENT: THE CASE OF SERBIA

Branislav Zoroja, National Bank of Serbia, Monetary Operations Department,

General Manager

CONCLUDING REMARKS

Miguel Savastano, International Monetary Fund, Monetary and Capital Markets

Department, Deputy Director

SPEAKERS' BIOS 
This page intentionally left blank 
This page intentionally left blank 
INTRODUCTION

Guido Della Valle, Erald Themeli, Romain Veyrune

\begin{abstract}
WESTERN BALKANS' CENTRAL BANKS CONFERENCE ON "NEGATIVE EURO AREA INTEREST RATES AND SPILLOVERS ON WESTERN BALKAN CENTRAL BANK POLICIES AND INSTRUMENTS"
\end{abstract}

Western Balkans are an economic area of over 20 million people with six states - Albania, Bosnia and Herzegovina, FYR of Macedonia, Kosovo, Montenegro, and Serbia - which all aspire to membership in the European Union (EU) and enjoy "candidate" or "potential candidate" status in the EU accession process.

The countries in the region have a history of conflicts evidenced by the term "Balkanization," which, based on the Balkan peninsula experience in the 19th and the beginning of the 20th century, is used to describe the process of fragmentation of a region or state into smaller regions or states that are often uncooperative with one another. Notwithstanding this past, the countries in the region share common economic objectives, challenges, and opportunities at the present.

They all aim to promote peace and prosperity in the region. They have all faced the challenge of a transition to a market economy. They all have strong economic and financial ties to the EU as a whole and to the euro area in particular via different economic, trade, financial, and monetary channels. They all have a common objective of joining the EU first and the euro area later.

They are faced with similar economic, financial stability, and monetary policy challenges. To name a few of these common challenges: despite recent growth acceleration, for the past eight years growth 
rates have been in low single digits at best. Supplies of foreign credit and capital from private sources - plentiful in the pre-crisis years have largely dried up, and EU-headquartered banks, which have a large presence in the Western Balkans, are coping with a new global regulatory context in which they are encouraged to deleverage and reduce cross-country exposure. At the same time, governments face severe limits in what they can do to tackle these problems. The fiscal space for Keynesian-style public spending projects is limited, while monetary policy is naturally constrained in these small open economies, which all have a high degree of euroization.

There are several initiatives aimed at revitalizing multilateral ties throughout the Western Balkans and improving regional cooperation on the issue of economic development. Still there is scope for further initiatives to exchange views and experiences on the responses given to common challenges, enhance cooperation, and shape joint initiatives across the countries in the region. This applies to monetary policy, financial stability, and central bank policies in general.

Against this background of common objectives and similar challenges, the IMF and the Bank of Albania, with the gratefully acknowledged financial support of the Swiss Government, have organized this conference among senior central bank policymakers of Western Balkan central banks and beyond. The topic of the conference is negative euro area policy rates and, more precisely, the economic and financial consequences for the Western Balkan countries of negative euro area interest rates and the recent standard and non-standard monetary policy measures implemented by the European Central Bank (ECB). It has an ambitious agenda since it aims at discussing and analyzing the consequences of recent ECB monetary policy from three important perspectives: financial stability, reserve management, and monetary policy. The conference provides policymakers in the region and beyond with a forum for discussing recent policy challenges, the policy responses, and their effects as seen from several key dimensions. From this perspective, the ultimate aim of the conference is to identify the policy responses that can be considered relatively more effective in given circumstances.

The conference also benefits from the participation of central bankers from countries in the proximity of the euro area that have 
also grappled with the euro area monetary policy spillover effects and have devised a different monetary and financial stability policy response reflecting the individual characteristics of each country. It is indeed our belief that the Western Balkans can not only benefit from learning from each other, but also benefit from the experience of other countries in the EU and in its proximity. This regular exchange of experience may gradually pave the way to greater economic cooperation.

In terms of content, the conference provided several interesting and useful insights. They can be summarized as follows. While the $\mathrm{ECB}$ is expected to reduce in the coming months the extent of the monetary policy accommodation provided and gradually exit from its nonconventional measures, lower average interest rates throughout the economic cycle are expected to prevail in the foreseeable future. In this case, the effective lower policy rate bound may become more frequently binding.

Negative interest rates have been effective in the countries in which they have been deployed. Negative consequences did not materialize, at least to the extent initially thought. Furthermore, potential negative impacts were either outweighed by the positive contribution negative interest rates provided to inflation and inflation expectations, or they could be prevented with a few carefully designed instruments, such as the tiered reserve remuneration scheme and the dynamic exemption scheme as a function of banknote demand, as was implemented by the Swiss National Bank (SNB).

Low policy rates in the euro area and the recent package of nonstandard monetary policy instruments deployed have had in general positive spillover effects in the Western Balkans, both directly and indirectly. These effects have been largely independent from the monetary policy and exchange rate regimes adopted. This is confirmed by both the econometric analysis conducted and presented by the ECB and by the anecdotal feedback from the policy-makers in the region. They benefited the countries in the area via the trade channel with a positive export shock and higher imported prices. They also benefited the countries in the region via cross border flows, lower risk premia, lower pressure on the exchange rate, and greater scope for domestic accommodative monetary policy. Furthermore, if the 
extent of the monetary policy accommodation had positive spillover effects, policymakers from the Western Balkans need to remain vigilant on the consequences that may derive from the forthcoming reduction in the ECB monetary policy stimulus.

The effective lower policy rate bound varies from country to country and in each country over time, as economic agents adapt to lower interest rates, as instruments are deployed to mitigate the possible negative consequences of low interest rates on financial stability risks, and depending on the availability of alternative non-standard monetary policy instruments. While the ECB and the SNB could effectively lower rates below zero, elsewhere the effective lower bound can be higher. Albania has deployed an interesting conceptual framework to analyze the effective lower bound and the scope for additional standard monetary policy accommodation. When the effective lower bound is reached, if additional accommodation is needed in the pursuit of the price stability mandate, nonstandard measures need to be deployed. The most effective non standard measures vary depending on the economic and financial system characteristics of each country. Therefore, if countries like Switzerland and the Czech Republic were effective with the implementation of an exchange rate floor to prevent destabilizing exchange rate appreciation, in others, like Hungary, a different set of instruments has been considered more effective.

As regards financial stability, low ECB policy rates and the package of nonstandard measures do not seem to be fueling any large-scale asset bubble in the countries in the region. Banks are still coping with a high level of non-performing loans (NPLs), are still in general applying tighter lending standards, and are in a deleveraging mode also as a consequence of the new global and EU regulatory frameworks. Credit growth remains in general subdued, banks are trying to transition toward a self-funded business model relying to a much smaller extent on funding from the EU parent, and EU banks have undertaken a general reassessment of their engagement in the region. If these factors may have helped containing financial stability risks, they also represent a challenge going forward to undertake financial system reforms to diversify the funding sources available and reduce the reliance on the banking system. Such a general picture hides, however, some heterogeneity across countries, with some countries requiring closer vigilance than others. 
Excessive euroization is the single most important structural financial stability risk with which countries in the region that are not de facto fully euroized, like Kosovo and Montenegro, are confronted. Low euro area interest rates and lower domestic policy rates in the Western Balkans provide both opportunities and challenges to address high euroization levels. They compress interest rate differentials, making, on the one hand, loans in foreign currency less financially advantageous than domestic loans, but they also lower the premium paid on domestic deposits, thereby reducing the opportunity costs of foreign currency deposits. Countries in the region need a mediumto long-term strategy to cope with this phenomenon. Such a strategy would need to define the policy instruments to be deployed over an appropriate time horizon, to lower euroization levels, contain the financial stability risks it induces, and enhance the effectiveness of monetary policy.

As regards reserve management, negative euro area interest rates have made it increasingly difficult to achieve positive returns in a negative interest rate environment for countries that need to hold a sizeable part of their foreign exchane (FX) reserves in euro due to the trade and financial links to the euro area. Negative euro area interest rates have challenged the traditional optimization model with which FX reserve portfolio composition was defined, that is, maximize expected portfolio returns under the constraint that the portfolio should not have a negative return based on a predefined, high confidence level. Negative interest rates mean that if negative returns should be avoided, reserve managers need to take up greater FX, interest rate, and credit risk, thereby increasing the risk of negative returns, in a tail scenario while if risks are minimized, portfolio returns are more likely to be negative. These problems are accentuated by two factors. First, the sizeable reserves held by the countries in the region also as a safeguard against financial stability risk. Second, the importance of FX reserve revenues from a central bank profitability perspective, which is perceived in several countries as a guarantee of independence.

Countries in the region and beyond have in general responded to these reserve management challenges via two radically different strategies. Some countries like Romania and Albania have prioritized safety and liquidity in the management of their reserves to serve the insurance 
purpose for which reserves are held. However, they have seen FX reserve income decline and may be confronted with marginally negative returns in 2017. Other countries have more aggressively pursued yield-enhancing strategies in pursuit of higher returns and to avoid negative returns on FX reserve holdings. These strategies have encompassed currency diversification, the addition of new asset classes, longer duration, and extra credit risk. These strategies seem to have paid off under the prevailing benign financial market conditions. However, when it comes to core reserves, as defined by their reserve adequacy target, it is of fundamental importance that they are managed with a risk tolerance that is consistent with the contingent macro risks that they are designed to cover. These strategies should therefore also prove to be resilient during more turbulent market times and the expected ECB exit from the current high level of monetary accommodation.

These considerations are elaborated in the transcript of the conference speeches included in this publication. They are underpinned and corroborated by facts and figures. Country-specific considerations are discussed in greater details in the policymakers' speeches included, whereas keynote addresses, with which each session is introduced, provide a more general, cross-country analytical, and conceptual framework to interpret individual countries' experiences.

The highly distinguished speakers, whose interesting presentations held during the conference are included in this publication, and the feedback received during and after the event, confirm the great interest elicited by the conference.

There seems to be, therefore, a case for considering such a conference not as a one-off event but, in line with the auspices of several participants, to turn it into a recurrent event. This would provide a forum for senior central bankers and policy officers in the region to regularly exchange experiences of the common challenges faced and their responses. The events would support cooperation among the countries in the region that is expected to become closer and more fruitful in the years ahead. 
This page intentionally left blank 
This page intentionally left blank 
Schweizerische Eidgenossenschaft

Confédération suisse

Confederazione Svizzera

Confederaziun svizra

State Secretariat for Economic Affairs SECO
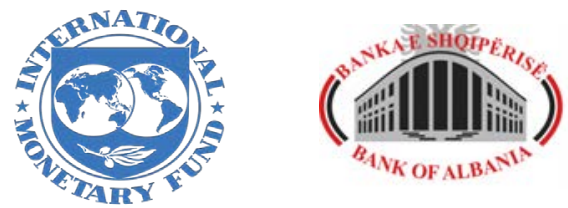

\section{NEGATIVE EURO AREA INTEREST RATES AND \\ SPILLOVERS ON WESTERN BALKAN CENTRAL BANK POLICIES AND INSTRUMENTS \\ MAY $4-5,2017$}

\section{CONFERENCE AGENDA}

Day 1: May 4, 2017

\section{Welcome Addresses}

- Gent Sejko, Bank of Albania, Governor

- Christoph Graf, Ambassador of Switzerland in Albania

- Miguel Savastano, International Monetary Fund, Monetary and Capital Markets Department, Deputy Director

Session 1: Negative euro area interest rates and financial stability: a first look beyond the Western Balkans and general trends

Moderator: Klodion Shehu, Bank of Albania, Financial Stability Department, Director

- Keynote address: Julia Woer:, Oesterreische Nationalbank, Foreign Research Division, Head: "How do interest rate differentials impact on euroization? Evidence from the OeNB's Euro Survey"

- Romain Veyrune, International Monetary Fund, Monetary and Capital Markets Department, Senior Economist: "Negative euro area interest rates and an effective de-euroization strategy" 


\section{Session 2: Negative euro area interest rates and financial stability in Western Balkan economies}

Moderator: Natasha Abmetaj, Bank of Albania, Second Deputy Governor

- Klodion Shebu, Bank of Albania, Financial Stability Department, Director: "Implications of low interest rates for financial stability in Albania"

- Belma Colaković, Central Bank of Bosnia and Herzegovina, Chief Economist: "What is obscured by aggregate data in the case of Bosnia and Herzegovina?"

- Arben Mustafa, Central Bank of the Republic of Kosovo, Advisor to the Governor: "Financial stability under unilateral Euroization: the case of Kosovo"

- Milena Vucinic, Central Bank of Montenegro, Financial Stability Department: "ECB nonstandard monetary policy measures and financial stability in Western Balkan economies with emphasis on the case of Montenegro"

General Discussion

\section{Session 3: Negative euro area interest rates and reserve management}

Moderator: Elisabeta Gjoni, Bank of Albania, First Deputy Governor

- Keynote address: Roberto de Beaufort Camargo, World Bank, Lead Financial Officer: "Are you prepared to assume the risk of increasing EUR yields?”

- Victor Andrei, National Bank of Romania, Market Operations Department, Director: "Negative euro area interest rates and reserve management at Central Bank of Romania"

- Sandor Ladányi, Magyar Nemzeti Bank, Foreign Exchange Reserves Management Strategy Department "Implementation of the new FX reserves investment strategy at the central bank. of Hungary"

General Discussion 


\section{Session 4: Negative euro area interest rates and reserve management (continued) \\ Moderator: Roberto de Beaufort Camargo, World Bank, Lead Financial Officer}

- Marian Gjermeni, Bank of Albania, Market Operations Department, Director: "Reserve management challenge: Stability vs. Return"

- Vesna Hristouska, National Bank of the Republic of Macedonia, Financial Market Operations Department: "Reserve management at the National Bank of the Republic of Macedonia in a context of negative euro area interest rates"

General Discussion

Day 2: May 5, 2017

Session 5: Negative euro area interest rates and monetary policy in the proximity of the euro area

Moderator: Guido Della Valle, International Monetary Fund, Monetary Policy Advisor

- Keynote address: Ryan Banerjee, Bank for International Settlement, Senior Economist: "Monetary policy in the proximity of the euro area, what changes with negative euro area rates?"

- Ulrich Bindseil, European Central Bank, Market Operations, Director General: "Rationale of accommodating ECB monetary policy, experience and outlook"

- Thomas Moser, Swiss National Bank, Alternate Member of the Governing Board: "Monetary Policy below the Zero Lower Bound"

- Dana Hajkova' Czech National Bank, Advisor to the Bank Board: "Monetary policy and exchange rate commitment in the Czech Republic"

- Daniel Felcser, Magyar Nemzeti Bank, Monetary Policy Analysis Department, Senior Economic Analyst: "Non-standard monetary policy in a low interest rate environment"

General Discussion 
Session 6: Negative euro area interest rates and monetary policy in the Western Balkans

Moderator: Erald Themeli, Bank of Albania, Monetary Policy Department, Director

- Keynote address: Isabella Moder, European Central Bank, Economist: "Spillovers of the ECB's non-standard monetary policy measures on Southeastern Europe"

- Guido della Valle, International Monetary Fund, Monetary Policy Advisor: "Estimating the lower policy rate bound in an euroized economy"

- Anita Angelovska Bezhoska, National Bank of the Republic of Macedonia, Vice Governor: "Conduct of monetary policy at National Bank of the Republic of Macedonia: recent challenges and policy response"

- Branislav Zoroja, National Bank of Serbia, Monetary Operations Department, General Manager: "Conduct of monetary policy with financial stability issues and challenging environment: Case of Serbia"

General Discussion

\section{Concluding Remarks}

- Miguel Savastano, International Monetary Fund, Monetary and Capital Markets Department, Deputy Director 
This page intentionally left blank 
This page intentionally left blank 


\section{WELCOME ADDRESSES}


This page intentionally left blank 
I am privileged to open this conference organized by the Bank of Albania and the IMF, with the gratefully acknowledged financial support of the Swiss Government.

This conference focuses on the economic and financial consequences for the Western Balkan countries of negative euro area interest rates and, more broadly speaking, of the recent standard and nonstandard monetary policy measures implemented by the ECB. It has an ambitious agenda since it aims at discussing and analyzing the consequences of recent ECB monetary policy from three important perspectives: financial stability, reserve management, and monetary policy. The conference aims at providing policymakers in the region and beyond with a forum for discussing the recent policy challenges, the policy responses, and their effects.

Western Balkans refers to the six EU candidate and potential candidate countries in the region: Albania, Bosnia and Herzegovina, Kosovo, the Former Yugoslav Republic of Macedonia, Montenegro, and Serbia. Taking a regional perspective is useful given the similarities in economic structures of the countries concerned. To a large extent, these similarities reflect the common background of transition to a market economy and the common goal of joining the European Union first and the euro area later. Such common goals represent a fundamental policy anchor for the countries in the region.

* Gent Sejko, Governor of the Bank of Albania 
Economies in the region are strictly interwoven with the euro area via different, important channels.

- First, the trade channel: euro area countries represent our main trading partners, accounting, in the case of Albania, for approximately 75 percent of our exports.

- Second, via capital flows in terms of foreign direct investments (FDIs), portfolio flows, and banks' funding. FDIs from the euro area represent 64 percent of total FDIs in Albania. Subsidiaries of banks headquartered in the euro area have a significant market share in several countries in the region. In Albania, this share has been declining, but it is still above 55 percent.

- Finally, remittances from the EU are an important source of income and foreign currency inflows in the region. In the case of Albania, they represent roughly 6 percent of GDP, and the majority of them are from euro area countries.

Countries in the region have, therefore, been strongly exposed to recent economic and financial developments in the euro area. Let me name just a few of these relevant developments.

Low inflation rates in the euro area were transmitted to our economies, hindering the achievement of our price stability objective. Since September 2012, core inflation in the euro area and non-euro area EU countries has decoupled from the average in the rest of the world. The synchronized disinflation across Europe points to a spillover of low inflation from the euro area to the Western Balkan' region.

Countries' susceptibility to inflation spillovers from the euro area should vary with the degree of trade openness and the rigidity of the exchange rate regime. The share of foreign value-added content in aggregate demand is over 50 percent in Albania. This ratio is higher in smaller Central and Eastern European (CEE) countries, which are more exposed to disinflationary spillovers from the euro area through the trade channel. Spillover also took place in countries, like Albania, though our state-of-the-art Inflation Targeting framework, and the flexible exchange rate regime insulated us somewhat from the strong disinflationary forces from abroad. 
Negative euro area policy rates as a reaction to low inflation rates have several repercussions. Their first impact is, of course, positive in countries that witness a degree of cyclical convergence with the euro area and that faced a similar shock to prices and economic activity. Inasmuch as negative rates have been successful in preventing disinflation across the euro area, they have helped central banks across the region to deliver on their mandate of price stability. Furthermore, countries in the region may have also benefited from portfolio and capital flows from euro area countries, encouraged by negative euro area interest rates and the largescale asset purchase programs of the ECB.

However, negative euro area interest rates also pose challenges to our monetary policy frameworks:

- First, they complicate the estimation of the lower policy rate bound in our economies.

- Second, they alter the relative incentives toward domestic and foreign currency denominated assets and liabilities, presenting both opportunities and challenges in the attempt to limit the euroization of our financial systems.

- Third, they lower the return on our FX reserve assets, which turned, at times, negative, in a context in which, unlike other countries, the scope for currency diversification is more limited. This presented peculiar challenges to our required reserves' system and the modalities with which banks' required reserves are remunerated.

In addition, our domestic financial systems have been affected through the presence of subsidiaries of euro area banks, in turn exposed to the regulatory tightening of the European banking sector as a reaction to the vulnerabilities exposed from the financial market crisis. We should eventually all benefit from a stronger, better capitalized, and more resilient banking system.

However, in the short-term, the adaptation to this new regulatory environment presents challenges as a result of a few factors.

- First, the deleveraging mode of several European banks in pursuit of higher capital ratios.

- Second, the adoption of new lending standards at group levels 
that do not always reflect the peculiarity of each market.

- Third, the criteria to be met to establish the equivalence in the regulatory and supervisory frameworks to benefit from lower risk weights are not clear.

All these factors result in different business behaviors between subsidiaries of euro area banks and other domestic and foreign owned banks, which is quite evident in Albania.

These spillover effects are not unique to Western Balkan countries, but have also affected other countries in the proximity of the euro area. The conference, therefore, benefits from the participation of some of these countries, like Czech Republic, Romania, and Switzerland, and their willingness to share their experience.

We have very distinguished speakers to discuss these topics in depth in the coming two days so that we can all benefit from the experience of each other. I am sure that you will be able to provide invaluable insights into these challenges and your policy response. It is my honor to welcome you all to Tirana.

I do hope you will find the conference useful.

To conclude my introductory remarks, let me take this opportunity to issue a few thanks to our long-term partners and conference coorganizers.

The Swiss Government via its State Secretariat for Economic Affairs - SECO - has supported the Bank of Albania throughout the years via various initiatives and the sponsorship of important technical cooperation projects. In the context of this well-established and successful cooperation, they are sponsoring the organization of this important conference.

I would also like to highlight the valuable technical assistance provided by the IMF, which has contributed to capacity building at the Bank of Albania throughout the years. This fruitful cooperation continues, as evidenced by the joint organization of this conference and some of our presentations. 
Therefore, let me express our sincere gratitude to Ambassador Graf and Miguel Savastano, Deputy Director of the Monetary and Capital Markets Department at the IMF and author of seminal papers you are well acquainted with. 
This page intentionally left blank 
I am pleased to welcome you to this regional conference to discuss macroeconomic and monetary policies related to the effects of the eurozone's low inflation rate and the negative interest rates. I very much welcome this opportunity to debate on links and implications of such tendencies on the Western Balkan countries.

The Western Balkan countries need more technical, evidencebased, and un-politicized debate. This conference is about technical expertise feeding good policies. And it might contribute to foster the integration of the Western Balkans region. Since I am not a technical expert, let me just point to some general political considerations.

First of all, I am very pleased that this conference is taking place in Tirana, Albania. I take this as a clear sign that Albania is about to get rid of its image as an isolated location, and that it seeks open exchange and strong international links.

How does the current political landscape in Europe as well as in the Western Balkans look in general? The situation does not seem as smooth and stable as we were used to a couple of years ago, but rather volatile and less predictable. If we look at Europe, there is BREXIT, nationalist tendencies, the upcoming French elections. If we look at the Western Balkan countries, there are the known tensions within the region, there is an ongoing crisis mode in some countries, there are general ups and downs that we are almost getting used to as political everyday life.

* Christoph Graf, Ambassador of Switzerland in Albania 
Against this relatively volatile political background, it is important that the macroeconomic framework does not add unnecessary volatility and insecurity to societies in Europe and the Western Balkans. In fact, I am pleased to note that in the Western Balkans, the macroeconomic situation presents overall a rather comforting picture over the past years, a picture of a relatively stable economic environment and growth. That is good news!

Europe and the Western Balkans are not only two neighboring regions; they are closely linked to each other. Geographically, looking at the map of Europe, the countries of the European Union are practically embracing the six Western Balkan countries. Economically, Europe is the most important commercial partner for the Western Balkans region; Montenegro and Kosovo even have the euro as a national currency. And politically, all Western Balkan countries are looking toward Europe or the EU, are somehow on the path toward EU accession (cf. Albania). On the other hand, also Brussels emphasizes the importance and its strong link to the Western Balkan countries, for instance with the so-called Berlin process.

Therefore, the topic of today's conference is relevant for a sound, healthy, transparent, and predictable relationship between the Western Balkans and Europe that extends in the area of macroeconomic stability.

What is in it for Switzerland? Why is the Swiss Government supporting this regional conference? Let me emphasize three considerations:

1. Switzerland is interested in building a strong and stable Western Balkan region with strong ties to Europe - both in the spirit of a European partner in the heart of Europe, and in the spirit of development and cooperation.

2. Based on the Swiss experience, I am convinced that macroeconomic and financial sector stability is crucial for economic growth. After all, financial and macroeconomic stability and prosperity are common goals for all the countries gathered here. A sound monetary policy supports macroeconomic stability and growth. It fosters a conducive environment for private sector initiatives. That is why my 
government assists various countries in the region and around the globe in strengthening monetary policies. This conference is part of that effort.

3. There is so much we can learn from others who have faced problems related to macroeconomic or monetary policy developments linked to the eurozone. Can you think of a country neighboring the eurozone that had to adapt monetary policies in response to developments of the euro? Well, Switzerland, exactly. Two years ago, the decision of the Swiss National Bank to drop the guarantee of a floor to the Swiss franc exchange rate vis-à-vis the euro was a shock, almost a traumatic experience for the Swiss economy and society. A representative from the Swiss National Bank will address this conference later, so you will be able to hear more about this story. But also experts from similar non-euro area countries will share their experiences. We all, and particularly the Western Balkan countries, do not have to reinvent the wheel. Peer exchange and sharing concrete experience are enriching and powerful.

I am pleased to note the experts and researchers from many different countries are present here. I hope you all will contribute and benefit from the exchange, the discussions, and conclusions of this conference.

Let me express my gratitude to the Bank of Albania and the International Monetary Fund for the initiative to gather representatives and experts here in Tirana and for organizing this conference.

I wish us all a very fruitful and inspiring event. 
This page intentionally left blank 
I would like to thank Governor Sejko for his kind words, and more importantly, for hosting what promises to be a very interesting conference in Tirana.

I also would like to thank Ambassador Graf and the Swiss Government, especially its State Secretariat for Economic Affairs (SECO), for the financial assistance they provide in support of many IMF capacity-building projects, like in Albania.

It is an honor for me to represent the MCM Department of the IMF in this gathering. As most of you know, one of the main activities of the MCM Department is assisting with capacity building in IMF member countries in the areas of monetary policy and financial stability.

Capacity building in these areas is a very rewarding activity. It is rewarding because it challenges us, IMF staff, to find innovative ways to transfer general principles or recent advances in the areas of monetary policy and financial stability to the specific realities of our member countries.

This transfer is never a one-way process, from Fund staff to the country officials. It is always a two-way process. And both parties benefit from it. I can tell you from my own experience that we, Fund staff, learn a lot from capacity building. And we also are able to see that countries benefit from it as well.

* Miguel Savastano, International Monetary Fund, Deputy Director of the Monetary and Capital Markets (MCM) Department 
Albania's successful adoption of an inflation-targeting framework is an excellent example of this two-way cross fertilization process. The country has clearly benefitted from having a more transparent and effective monetary policy framework, and a low and stable rate of inflation. And Fund staff have learned from this successful implementation, too.

Conferences like this are another important dimension of capacity building. Learning about experiences of similar and not so similar countries is a very useful and important knowledge-sharing activity. And learning about how a group of countries responds to a common external shock, which is the main theme of this conference, is particularly important.

In fact, one of the most important lessons I have learned in my 25 years at the Fund is that global financial conditions matter a lot. Global shocks elicit policy responses from the large world economies. And those policy responses create spillovers in other economies. All the presentations and discussions that we will have in this conference have to do with spillovers. Because we are in the Western Balkans, the spillovers of most relevance are those related to the monetary policy and financial conditions in the euro area. If we were somewhere else in the world, we would probably be discussing spillovers from the US monetary policy, or from China's.

That is just the way it is. In small open economies, policy making is affected by and has to be responsive to changes in global financial conditions. This has to happen probably to a larger extent than what simple textbook models would suggest. And it is precisely because reality is more complex than textbook models that these conferences are so important. There is a lot to learn from discussions and exchanges of views among central bankers, policymakers who share the same objectives and face the same external shocks.

The policy toolkits may be a bit different, the domestic circumstances would probably be even more different, but the external shock they are confronting is the same, and the challenges that arise from the spillovers from that shock are also very similar. 
For the Western Balkans, the external shock that created the spillovers that will be discussed in this conference is the extremely accommodative monetary policy of the ECB.

The ECB adopted that extremely accommodative monetary policy almost five years ago, mostly in response to the global financial crisis and subsequent sovereign debt crisis that afflicted the euro area economies in 2011-12. By all standards, the ECB did what it had to do to ease monetary conditions to mitigate the contractionary effect of a financial crisis and provide liquidity to the financial system and the sovereigns. The ECB has also been mostly right in keeping monetary policy loose for as long as it had (some people disagree with this, but we, at the Fund, still are of the view that they were right).

But this policy of the ECB has created important spillovers for countries outside the euro area, like the Western Balkans and some countries in Central Europe. Those spillovers have taken several forms: deflationary pressures, downward pressures on interest rates, lower FX intermediation spreads, lower return on FX reserves, and upward pressure on the exchange rate.

The challenges brought about by these spillovers could not have been anticipated a few years ago, including because some of the policies adopted by the ECB were not considered "conventional." But they have happened. And the central banks and other economic authorities of the neighboring countries have had to respond to this. The next two days will give us an opportunity to learn exactly what many of these countries have done, are doing, and are planning to do, to navigate these challenging times and mitigate the adverse effects of those spillovers on monetary policy, financial stability, as well as on FX reserve management.

I am very excited and looking forward to learning from all of you. 
This page intentionally left blank 


\title{
FIRST SESSION: \\ NEGATIVE EURO AREA INTEREST \\ RATES AND FINANCIAL \\ STABILITY: A FIRST LOOK \\ BEYOND THE WESTERN BALKANS \\ AND GENERAL TRENDS
}

\author{
Moderator: Klodion Shehu
}

Bank of Albania, Financial Stability Department, Director 
This page intentionally left blank 


\section{HOW DO INTEREST RATE DIFFERENTIALS IMPACT ON EUROIZATION - EVIDENCE FROM THE OENB EURO SURVEY}

Thomas Scheiber and Julia Woerz, ${ }^{1}$, Oesterreichische Nationalbank, Foreign Research Division

Euroization is a common phenomenon in the Central, Eastern, and Southeastern European (CESEE) region. Hence, the global environment of low interest rates and the ensuing lower interest rate differentials between local and foreign currencies also have a notable impact on euroization. In this chapter, we will focus on this important aspect within the broader topic that the conference sketches. We present here empirical evidence from the Oesterreichische Nationalbank (OeNB) Euro Survey ${ }^{2}$ building on a number of research papers published by OeNB researchers on the topic of euroization in CESEE.

First, we will illustrate some facts sketching the extent of euroization in the CESEE region. Second, we will briefly reflect on how very low interest rates would, in general, impact households' saving and borrowing decisions before we discuss more specifically the choice of currency for savings and borrowings. Third, we will look at the empirical evidence based on OeNB Euro Survey data, and finally we will draw some policy conclusions.

\footnotetext{
Based on an article from Scheiber, T., J. Wör. "How are reduced interest rate differentials affecting euroization in Southeastern Europe? Evidence from the OeNB Euro Survey," forthcoming in: Focus on European Economic Integration 1Q/18, Oesterreichische Nationalbank.

The opinion expressed by the authors does not necessarily reflect the official viewpoint of the Oesterreichische Nationalbank or of the Eurosystem. The authors are grateful to Elisabeth Beckmann (OeNB) for her helpful comments and valuable suggestions.

2 The OeNB regularly conducts a survey of households in CESEE: the OeNB Euro Survey collects unique information about (euro) cash holdings, saving behavior and debt, and looks into respondents' economic opinions, expectations, and experiences. See https://wmw.oenb.at/en/ Monetary-Policy/Surveys/OeNB-Euro-Survey.html
} 


\section{EUROIZATION AND INTEREST RATE DEVELOPMENTS}

IN CENTRAL, EASTERN, AND SOUTHEASTERN EUROPE

(CESEE)

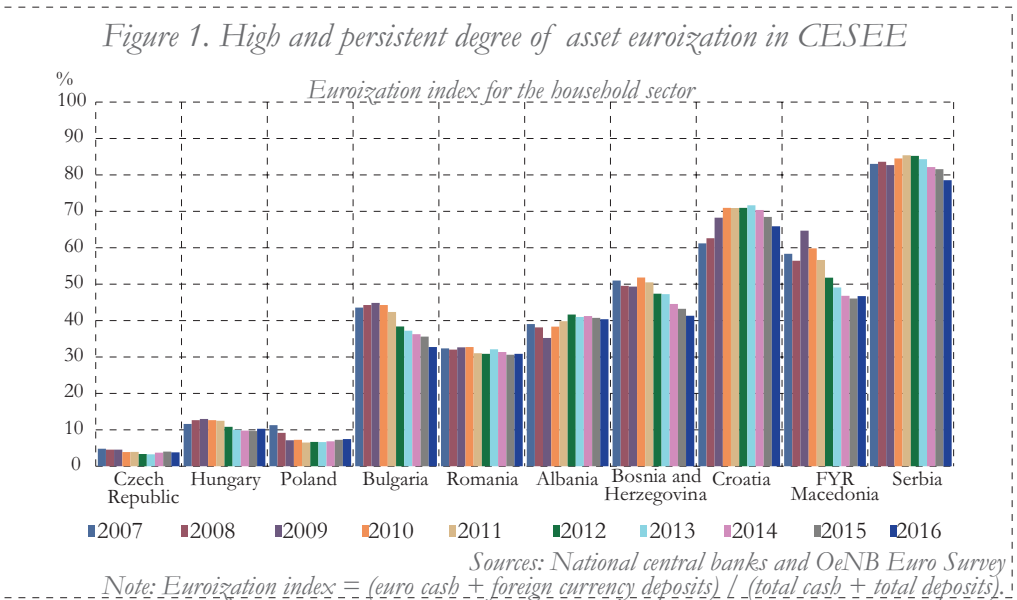

Figure 1 depicts the asset euroization index for CESEE households. ${ }^{3}$ Asset euroization is defined as euro cash holdings (taken from the OeNB Euro Survey) and foreign currency deposits (from monetary statistics of central banks) in relation to total cash holdings, and total deposits in each economy. Asset euroization is not an issue in countries like the Czech Republic, Hungary, or Poland, where its level is low. In countries like Albania, Bosnia, Bulgaria, and Romania, and more recently in the Former Yugoslav Republic of Macedonia (FYR Macedonia), asset euroization is at a medium level. Yet, Croatia and, in particular, Serbia continuously show very high levels of euroization. ${ }^{4}$

It is a well-established fact that asset euroization in Southeastern Europe is a persistent phenomenon, even though we have been observing some decrease in countries like Bulgaria, Bosnia, and the

Note that throughout this chapter we adopt the households perspective. So, when talking about asset euroization we refer to households, which is the counterpart to liability euroization of banks. Of course, given banks' net open foreign currency positions and the need to reduce exchange risks, a bigh degree of asset euroization of households will also act as an incentive for banks to increase their extent of asset euroization as well.

4 Note that the household sector includes non-profit institutions serving housebolds. If those were excluded, the ratio for Serbia would be even higher at around 90 percent. 
FYR Macedonia. The question arises why households in Southeastern Europe still prefer to save in foreign currency, despite sustainable macroeconomic stabilization over the past decade.

Looking at the empirical evidence, deposit substitution is to a large extent demand driven (Brown and Stix, 2015; Zettelmeyer et al, 2010). We know from the OeNB Euro Survey that households have broad access to a wide range of saving products in domestic and foreign currencies, yet they choose to save primarily in foreign currency (Beckmann et al, 2013). Brown and Stix (2015) provide evidence that deposit euroization is strongly related to monetary expectations whereby foreign currencies are considered to act as insurance against high exchange rate volatility and network effects. However, network effects can partly explain the observed degree of persistence. Furthermore, the authors show that monetary expectations are related to both individual experiences of past financial crises in the early 1990s as well as to respondents' assessments of current policies and institutions. Surprisingly, there are no differences between age cohorts. Even young people who lack personal experience of the past crises in the 1990s seem to be convinced in their thinking that foreign exchange deposits are safer than domestic currency deposits.

Looking at the liability side of households, recent research concludes that both demand and supply factors play a role. Again, most borrowers have a choice between a local currency loan and a foreign currency loan. Main determinants of households' demand for foreign currency loans are low interest rates, a lack of trust in the local currency, and high inflation or exchange rate volatility. (Crespo Cuaresma et al, 2011; Fidrmuc et al, 2013). Furthermore, expectations of euro introduction play a role in some countries as well as weak knowledge of the risk inherent in foreign exchange loans (Beckmann and Stix, 2015).

Turning to supply side explanations for high liability euroization, as mentioned before, the preference by households for foreigncurrency deposits implies that banks are highly euroized on the liability side. Therefore, in order to avoid currency mismatch in their balance sheets, banks have an incentive to lend in foreign currency. Obviously, while a major source of foreign-currency funding for 
the banks are foreign-currency deposits of their custumers, foreignowned banks will also have access to foreign-currency funding from their parent banks. On the other hand, Beckmann et al (2015) show that this factor was not the main driver of loan euroization, since lending practices between foreign-owned and domestically owned banks did not differ much, except in countries like Croatia andHungary.

Let us now turn to developments in interest rates before discussing the impact of low interest rates on euroization. We have observed a notable decline in interest rates over the past years.

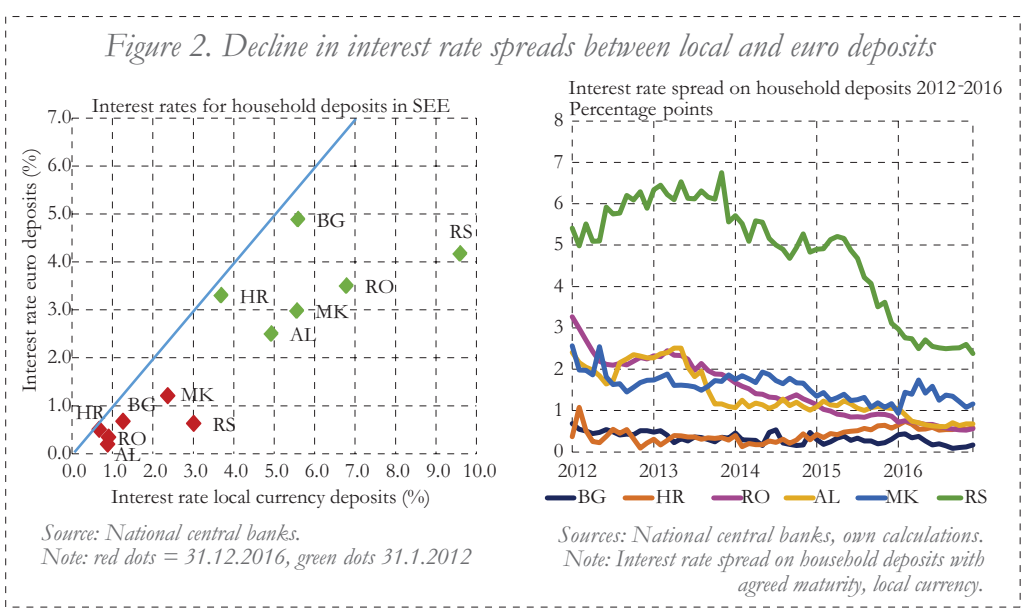

The left panel in Figure 2 shows that interest rates declined strongly between 2012 and 2016. This holds true not only for euro deposits (to be read from the y-axis), but also for domestic currency deposits (x-axis). The green diamonds represent the situation at the beginning of 2012 and the red diamonds show interest rates at the end of 2016 for individual CESEE countries. Clearly, interest rates on euro deposits always remained below those for domestic currency deposits (that is, below the diagonal).

While the international interest rate environment certainly induced some spillovers leading to a decline in interest rates, the right panel in Figure 2 clearly shows that also the spread between foreign-currency and local-currency interest rates has decreased substantially. Hence, 
also domestic developments must have played a role. Particularly in Serbia (green line), this trend is likely related to the successful macroeconomic stabilization in recent years. So, we observe for the CESEE region the impact of both policy spillovers from a low interest rate environment and a reduction in the spread leading to very low interest rates. Interest rates even turned negative in Bosnia and Bulgaria and became very low in Croatia, the FYR Macedonia, and Romania. They were slightly higher, but still low given the stage of economic development in countries like Albania and Serbia.

\section{IMPACT OF (VERY) LOW INTEREST RATES ON SAVING AND BORROWING DECISIONS AND CHOICE OF CURRENCY}

Let us briefly recap from economic theory what outcome we would expect for saving decisions if interest rates were falling to (very) low levels. In general, as opportunity costs are reduced, cash hoarding will become more attractive. Yet, in this particular region, the preference for saving in cash is strongly related to mistrust in banks and weak institutions (Stix, 2013). Yet, against the backdrop of an observed increase of trust in banks in some Southeastern Europe countries, this may countervail the expected effect.

With respect to borrowing and lending decisions, the borrowing costs for households is certainly reduced. This should lead to an increase in lending or higher demand for new loans. Moreover, banks experience a compression in their interest margin, which would induce them to issue more loans in an attempt to substitute price for quantity. This change in business model was observed in Denmark, Sweden, and Switzerland during the recent years of ultralow interest rates, when banks compensated for compressed interest rates via new lending and an increase in fees (Scheiber et al., 2016). Yet, in the Southeastern Europe region, some banks still deleveraged as a legacy from the crisis, which might give room to alternative forms of non-bank lending. ${ }^{5}$

There is not much evidence on this subject to date. Stern (2017) provides a first stocktaking of Fintech activities in the region. 
For small open economies, especially in countries where the use of foreign currency is high - as in Southeastern Europe, on which we focus here - not only the level of domestic interest rate matters for savings and borrowing decisions, but also the spread between local and foreign currency. Hence, we will briefly review the impact of a compressed interest rate spread between local and foreign currency. The majority of households save in foreign currency in order to protect their purchasing power. A lower spread actually compresses the insurance premium; as a result it should become even more attractive to save in euro or in other foreign currencies. In contrast to this, some households may search for yield and may prefer the relatively higher remunerated local currency deposits. This would make saving in the local currency more attractive. Again, the net effect remains an empirical question, and we will present some empirical evidence in the next section.

Turning to the borrowing decision of households, it is clear that borrowing in foreign currency becomes relatively less attractive in an environment of low domestic interest rates, provided consumers are able to judge foreign currency risk correctly. Again banks could compensate for the decline in spread through an increase in the volume of lending. If for the reasons outlined before, foreign currency deposits of banks increase in the low interest rate environment, the increase in the volume of lending could be tilted toward foreign currency driven by their attempt to reduce the currency mismatch. To sum up, in the presence of low interest rates and a low spread between interest rates on local versus foreign currencies, demand for foreign currency deposits may well go up while at the same time foreign currency loans may become less attractive to households.

\section{EMPIRICAL EVIDENCE FROM THE OENB EURO SURVEY}

The OeNB Euro Survey provides a good source of data to test most of the hypotheses outlined before. This survey is conducted among households in 10 CESEE countries, six EU member states (Bulgaria, the Czech Republic, Croatia, Hungary, Poland, Romania), and four non-EU countries (Albania, Bosnia and Herzegovina, 
the FYR Macedonia, Serbia). From 2007 to 2014, surveys were conducted twice a year; since 2015, the survey frequency was reduced to once a year (autumn). Using a standardized and hence comparable questionnaire across countries, the Euro Survey collects unique information about (euro) cash holdings, saving behavior, and debt, and looks into respondents' economic opinions, expectations, and experiences. Samples consist of 1,000 randomly selected respondents per country and represent the population over 14 years. Samples are representative with respect to age, gender, and regional distribution. In the following, we will combine information from the OeNB Euro Survey with data from national central banks to obtain a comprehensive picture of the impact of low interest rates and a reduced interest rate spread on euroization.

Let us look at three major channels through which the impact of reduced interest rate spread would spill over in the region: via cash holdings, via deposits, and via loan demand.

Figure 3. Cash holdings increased between 2012 and 2016
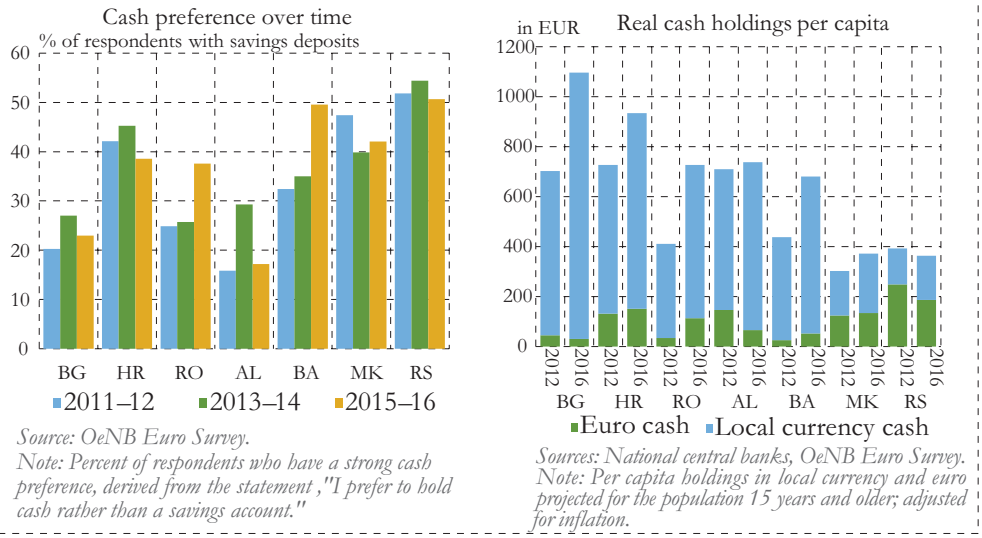

Source: OeNB Euro Survey.

Note: Percent of respondents who have a strong cash preference, derived from the statement, "I prefer to bold cash rather than a savings account."

Figure 3 shows both preferences and actual developments in real cash holdings per capita. Preferences for cash holdings and their evolution over time can be read from the left panel of the chart, while the right panel shows the actual behavior of households.

As a first result, we observe a high preference for savings in cash in Southeastern Europe. Even households with a savings account 
tend to agree with the statement that they would prefer to save in cash. Households' cash preference is highly persistent and related to a number of factors such as weak institutions, tax evasion, lack of trust in banks, and network effects in the use of foreign currency cash (Stix, 2013). Against the backdrop of the low interest rate environment and the decrease in the interest rate spread, we can identify two countries, Bosnia and Romania, where preferences have increased notably, whereas cash preferences in the other five countries here seem to be unaffected by these developments. ${ }^{6}$

Turning to developments in actual cash holdings (right hand panel of Figure 3), we observe some increase in cash holdings in Bosnia, Bulgaria, Croatia, and Romania, and more or less unaffected levels in Albania, the FYR Macedonia, and Serbia.

Apart from the low interest rate environment, there might be other reasons for the observed increase in real cash holdings in some countries. Lacking hard facts, we can only point to some events that might possibly be related to this behavior. In Romania, cash holdings have increased since autumn 2016, which could be also related to the political protests during that time. In Bulgaria, the banking turmoil in 2015 could have undermined trust in banks. Both of these factors would point to a high sensitivity of households in the region with respect to any crisis, which in turn induces an increase in cash holdings.

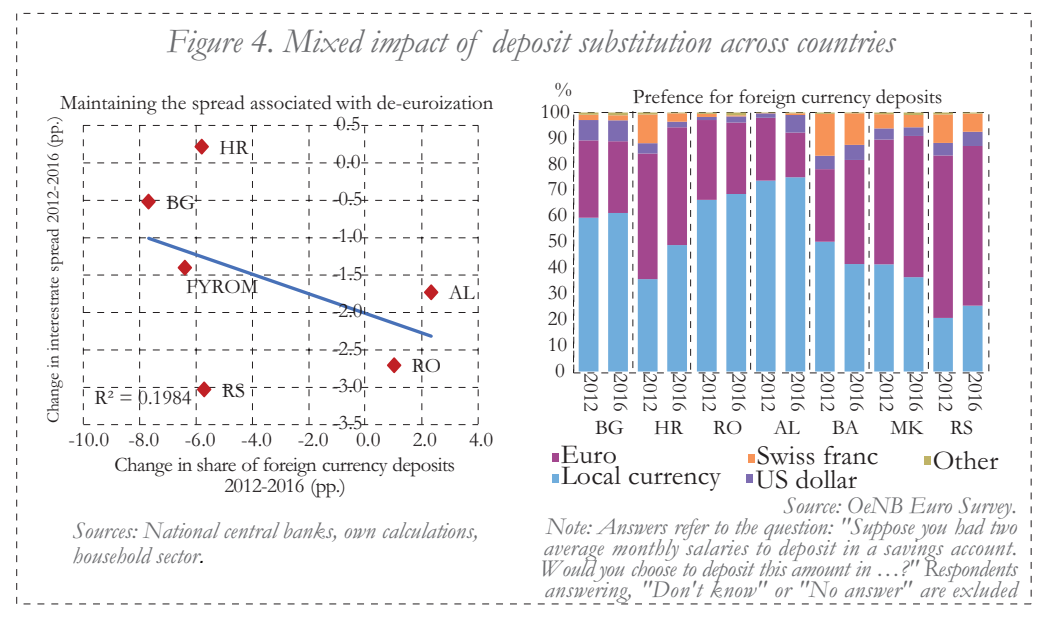

Note that we ignore changes that are below 5 percentage points here as variation in the datalike in any survey data - is rather high. 
Let us turn to the second channel. The evidence on the impact of low interest rate spreads on deposit substitution is rather mixed. As mentioned before, foreign currency deposits should increase in response to a decrease in the spread. However, the evidence presented in the left panel of Figure 4 shows that in almost all countries, the share of foreign currency deposits has declined at the same time as the interest rate spread declined. Only Albania, Croatia, and Romania exhibit the expected pattern.

A simple country-wise time series regression allows identifying some factors that correlate with the changing share of euro deposits in total deposits. ${ }^{7}$ Results indicate that the change in the spread had a significant effect on the decline in euro deposits in Croatia, the FYR Macedonia, and Serbia, but turned out insignificant for Albania and Romania. Hence, even when we control for some important variables, such as inflation, exchange rate developments, and exchange rate volatility, we find no evidence for the expected behavior in most of the countries except for Croatia. This is in line with the literature on euroization we presented before that deposit euroization in the region is driven by other factors and not strongly related to the interest rate differential or interest rate movements. For Serbia, these findings point in the direction that recent efforts of macroeconomic stabilization (which is the main driver of the observed compression of the spread) contribute to dinarization of household deposits.

The right-hand panel of Figure 4 shows that the preference for foreign currency deposits has actually decreased in Croatia and Serbia. In all other countries, it has remained relatively unchanged, except for Bosnia and Herzegovina, where the preference for euro deposits increased.

Bosnia is excluded because of a lack of data. 
Figure 5. Recent rebound in borrowing tilted toward foreign currency
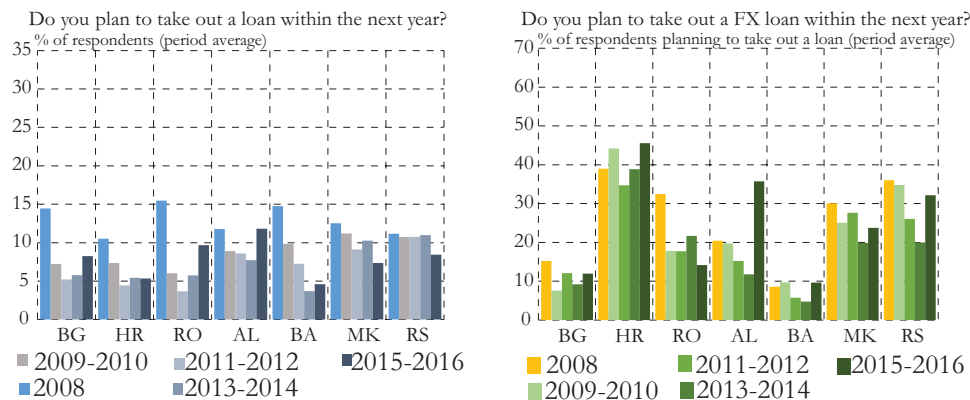

Source: OeNB Euro Survey.

Note: Respondents answering, "Don't know" or who refused to answer are excluded.

Finally, let us now discuss the last channel, the response of loan demand to low interest rate spreads. Based on the theoretically guided considerations above, we would expect an increase in loan demand to reduced interest rates. The left panel of Figure 5 reports the share of respondents who plan to take out a loan within the subsequent year for the years 2008 to 2016. After the global financial crisis, loan demand was depressed considerably for several years. More recently, loan demand re-emerged in Albania, Bosnia and Herzegovina, Bulgaria, Croatia, and Romania. We would expect this loan demand to be tilted, in theory, toward local currency loans given the reduction in interest rate spread and a correct perception of exchange rate risk. Surprisingly though, the right panel of Figure 5 reveals that among those respondents who plan to take out a loan, the share of households planning to take out a foreign currency loan is on the rise as well. Again, region-specific factors are driving this result.

From a policy perspective, it is worthwhile to investigate in more detail this surprising, and not necessarily desired, behavior. Beckmann (2017) presents evidence that recent debt relief measures for borrowers in CESEE countries have increased expectations of future government interventions (Figure 6). Interestingly, expectations of government bailout do not influence loan demand as such, but they increase the demand for foreign currency loans. These results are robust to controlling for knowledge of exchange rate risk 
and expectations about exchange rate developments and they hold throughout the region. While debt relief measures were of particular importance in countries like Croatia, Hungary, and Poland and less so in Southeastern European countries, the econometric evidence from this study shows more generally that debt relief for borrowers influences expectations so that people expect future bailouts. This leads them to underrate exchange rate risk even though they are aware of such risk. As a result, demand for foreign-currency loans may soar again. Hence, any such measure should be accompanied on the macro-prudential level with measures that would simultaneously rein in the demand for foreign currency loans, such as regulation prohibiting issuance of new foreign currency loans to households. Otherwise, well-intended policies targeted at relieving the debt burden of foreign currency borrowers may in the medium- to longterm lead to a re-emergence of foreign currency borrowing rather than the desired decline.

At the same time, however, banks will also react and most likely lower their supply of foreign currency loans, as they have to shoulder the cost of the bailout. Similarly, the interest rate on foreign currency loans may increase.

Figure 6. Impact of foreign currency debt relief measures on loan demand Expectations of government bailout
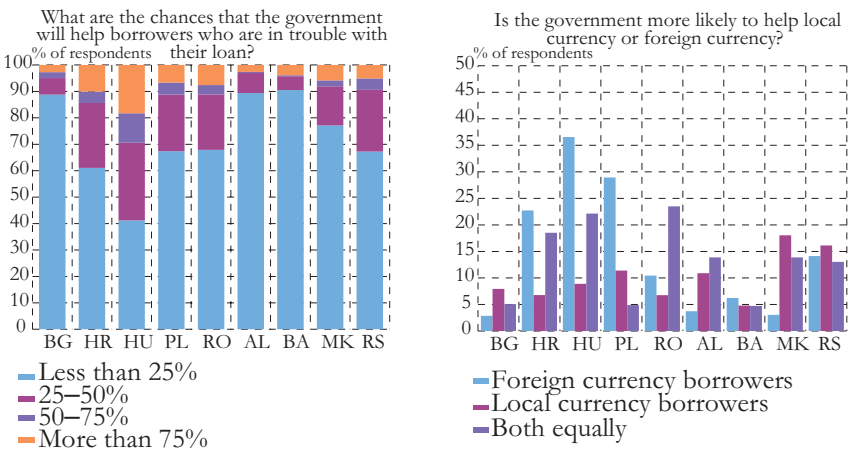

Source: Beckemann (2017) using OeNB Euro Survey, fall 2015. Note: Abbreviations represent the two-digit ISO country code. 1 


\section{POLICY IMPLICATIONS}

In this section, we reviewed descriptive and econometric evidence on the relationship between low interest rates, compressed interest rate spreads, and saving and borrowing decisions of households in CESEE countries in the recent era of very low interest rates. We have drawn on data from the OeNB Euro Survey as well as on a wide range of recently published articles based on this data and complemented the picture by statistics from national central banks, with a focus on Southeastern Europe.

We have found that a compressed interest rate spread fosters deposit euroization. In order to address this, measures such as reserve requirements, taxes, and the like should be taken to raise the "insurance premium" for foreign currency savings. Yet, policymakers in the region have to be aware that the alternative for households in their countries may not be to move to local currency deposits but to increase their euro cash holdings. Hence, a comprehensive policy mix has to accommodate all these potential reactions.

The evidence also shows that compressed interest rate spreads increases both supply and demand for foreign currency loans. Addressing the associated re-emergence of risks to financial stability requires both macro-prudential measures and micro-prudential supervision of lending practices. Furthermore, policymakers need to raise borrowers' awareness of foreign currency risks. In addition to stepped-up communication efforts, there is clearly a need to regulate foreign currency lending so that only hedged borrowers or unhedged borrowers with sufficient risk-bearing capacity can borrow in foreign currency. Complementary tools, such as higher provisions for foreign currency loans, can be considered, too.

Finally, a particularly characterizing feature of the Southeastern European region is the high level of cash holdings. Evidence from the OeNB Euro Survey suggests that knowledge about the existence of deposit insurance schemes is still rather limited in the region. Sometimes more than 50 percent of respondents were not aware of a deposit insurance scheme in their country, even though it existed. This suggests that there is still ample scope to build trust in the local 
banking sector. Of course, building trust is a long-term project. Yet, a lack of trust seems to be the crucial point driving euroization in the region. Hence, fostering trust in the institutions and a comprehensive policy mix of macro- and micro-prudential measures help to maintaining financial stability and to reduce euroization. 


\section{REFERENCES}

Beckmann, E., M. Hake, and J. Urvova. 2013. 'Determinants of Households' Savings in CESEE." Focus on European Economic Integration Q3/13, Oesterreichische Nationalbank, 8-26.

Beckmann, E., A. Roitner, and H. Stix. 2015. "A Local or a Foreign Currency Loan? Evidence on the Role of Loan Characteristics, Preferences of Households and the Effect of Foreign Banks." Focus on European Economic Integration Q1/15, Oesterreichische Nationalbank, 24-48.

Beckmann, E, and H. Stix. 2015. "Foreign Currency Borrowing and Knowledge About Exchange Rate Risk.” Journal of Economic Behavior \& Organization 112, 1-16.

Beckemann, E. 2017. 'How does foreign currency debt relief affect households' loan demand? Evidence from the OeNB Euro Survey in CESEE." Focus on European Economic Integration Q1/17, Oesterreichische Nationalbank, 8-29.

Brown, M., and H. Stix. 2015. "The Euroization of Bank Deposits in Eastern Europe." Economic Policy 30(81), 95-139.

Crespo Cuaresma, J., J. Fidrmuc, and M. Hake. 2011. "Determinants of foreign currency loans in CESEE: A Meta-Analysis." Focus on European Economic Integration Q4/14, Oesterreichische Nationalbank, 69-87.

Fidrmuc, J., M. Hake, and H. Stix. 2013. 'Households' Foreign Currency Borrowing in Central and Eastern Europe." Journal of Banking and Finance 37(6), 1880-1897.

Scheiber, T., M. Silgoner, and C. Stern. 2016. "The development of bank profitability in Denmark, Sweden and Switzerland during a period of ultra-low and negative interest rates." Focus on European Economic Integration Q3/16, Oesterreichische Nationalbank, 8-28.

Stern, C. 2017. "Fintechs and their emergence in CESEE." Focus on European Economic Integration Q3/17, Oesterreichische Nationalbank, 42-58.

Stix, H. 2013. "Why do people save in cash? Distrust, Memories of Banking Crises, Weak Institutions and Dollarization." Journal of Banking and Finance 37(11), 4087-4106.

Zettelmeyer, J., P. Nagy, and S. Jeffrey. 2010. "Addressing private sector currency mismatches in emerging Europe." EBRD Working Paper 115. 


\section{NEGATIVE EURO AREA INTEREST RATES AND AN EFFECTIVE DE-EUROIZATION STRATEGY}

Romain Veyrune, International Monetary Fund, Senior Economist

I will present today the results of the work that the IMF has conducted with the Bank of Albania on the issue of de-euroization as part of its technical assistance provision.

Figure 1 represents the cycle of euroization as we have witnessed it, with small differences in several countries. It starts with phase zero, which is the natural level of euroization. Here, the benefits of euroization balance its costs, and the level of euroization is mainly driven by structural factors.

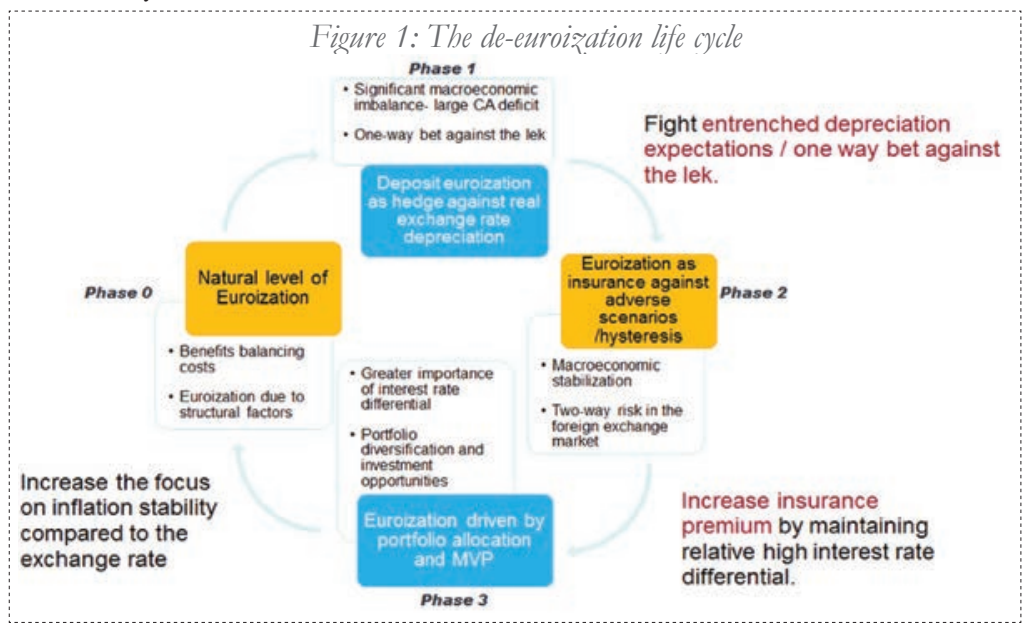

Then, because of external shocks or policy issues, significant macroeconomic imbalances emerge, which usually lead to a large current account deficit and exchange rate depreciation. Expectations of exchange rate depreciation become entrenched. As a result, wages are indexed to the exchange rate and saving is done in foreign currency as a hedge against exchange rate risk. 
Then the authorities step in and stabilize the macroeconomic context, which narrows the current deficit. As result, two-way exchange rate risk is reintroduced in the foreign exchange market; the risk of depreciation abates; the exchange may appreciate as well. It is more difficult to bet against the domestic currency.

However, the euroization usually does not disappear at that point, because the public is still attached to the insurance value of saving in foreign currency. While economic agents witness and are aware that in the short- to medium-term the exchange rate may move both ways, saving in foreign currency is still perceived as a cheap insurance against the risk of a recurrence of major macroeconomic shocks experienced in a non-distant past, which may engender an abrupt and significant exchange rate depreciation. So, what the policy makers can do in the short-term is to increase the "insurance" premium implicit in the foreign currency saving by keeping a minimum spread between the local currency and the foreign currency interest rate, widening it to the greatest possible extent via regulation while maintaining two-way risk in the foreign exchange market. At the same, by maintaining a stable macro-economic context, by strengthening institution and policy credibility, they should reduce the perceived risk of tail scenarios.

Then, you reach the third phase, where euroization is not due to hedging, is not due to insurance, but is the result of portfolio optimization, which means that the public saves in the currency that minimizes the variance of its saving portfolio. So, in that case, if you want to strengthen de-euroization of deposits, you must minimize the inflation compared to the exchange rate volatility to make saving in local currency the portfolio with the least variance. And it is there that the inflation targeting takes a more important role.

\section{PHASE 0: OPTIMAL LEVEL OF EUROIZATION}

Let's start from phase zero. What are the benefits of euroization? Financial euroization could contribute to financial deepening, by encouraging banks' deposits rather than hoarding foreign currency cash, the integration in the international capital markets, and the access to financially attractive foreign funding sources. 


\section{WHAT ARE THE COSTS?}

The financial cost of euroization includes the loss of seigniorage. When the public uses foreign currency banknotes, it reduces the circulation of local currency banknotes, leading to a smaller liquidity deficit in the banking sector, which reduces the profit of the central bank. Because of the financial stability risk due to euro deposits, the central bank must also keep more foreign reserves than without euroization, which have an opportunity cost. This cost is usually non-negligible and could be considered a fiscal loss. For Albania, it is between 0.4 percent to 0.6 percent of GDP per year.

Another issue is the effectiveness of monetary policy. First, euroization directly reduces the scope of financial intermediation that the central bank can influence. Second, financial euroization impairs the monetary policy transmission, as the exchange rate transmission channel negatively interacts with the interest rate channel. In a non-euroized economy, a decrease in the policy rate leads to a depreciation of the exchange rate and a decrease in banks' lending rates, which both support inflation. Factor in euroization, and the depreciation of the exchange rate due to a cut in the policy rate could lead to an increase in non-performing loans because of unhedged borrowers' exposure to the exchange rate risk, which in turn deteriorates lending conditions as banks try to recoup the losses due to higher non-performing assets.

The last issue with euroization is related to financial stability. As mentioned earlier, unhedged borrowers are exposed to exchange rate depreciation. The depreciation of the exchange rate could also affect local currency borrowers, as a typical defense against exchange rate depreciation is to raise domestic interest rates, leading to an increase in local currency non-performing loans.

It is not possible to accurately measure the cost and benefits of euroization, except for the loss of seigniorage. Therefore, we decided to estimate an empirical euroization benchmark, which is defined as the level of euroization that could be predicted based on a country's structural features. For the latter, we included the optimal currency area criterion, which determines the choice of an 
exchange rate arrangement and encompasses economic size, trade, and capital count openness, as well as remittances, which are also strongly correlated with euroization. We assume that the optimal level of euroization does not deviate much from its natural level.

Our estimate of structural euroization also includes policy variables. The objective is to neutralize them: we predict the level of euroization as if macroeconomic policies have not influenced euroization.

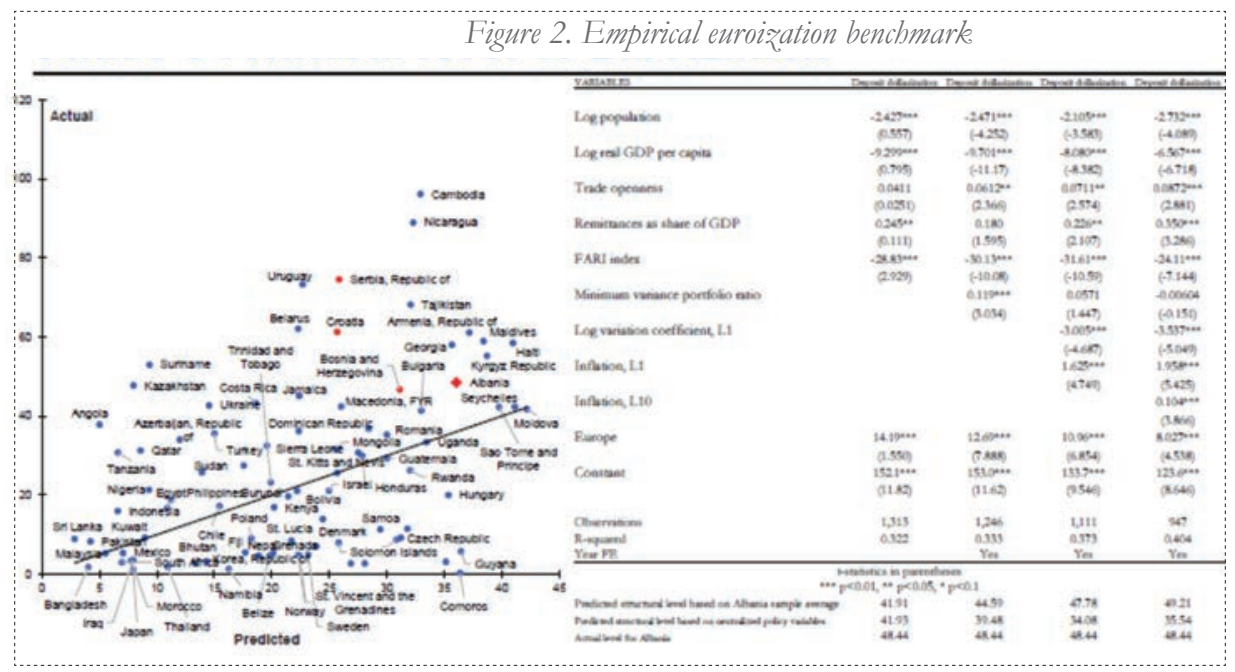

For Albania, we have estimated a natural level of euroization between 40 percent and 35 percent. It, therefore, deviates from the current level of 48 percent. It is not a very large deviation, and, relative to the other countries, Albania is not very far from its natural level. But the issue is that the deposits euroization increased recently, so it is deviating from this natural level, which justifies the recently announced de-euroization policies.

\section{PHASE 1: MAINTAINING TWO-WAY RISK IN FX MARKET}

The first step toward de-euroization is to introduce two-way risk in the market to fight one-way bets against the local currency. Figure 3 shows the odds of an exchange rate appreciation on an 80-day rolling basis. When the indicator is above one, the odds of an appreciation 
have been higher than the odds of a depreciation during the past 80 days. On the other hand, if the indicator is below one, the odds of a depreciation have been higher than the odds of a depreciation.

\section{Figure 3. Exchange rate appreciation odds}

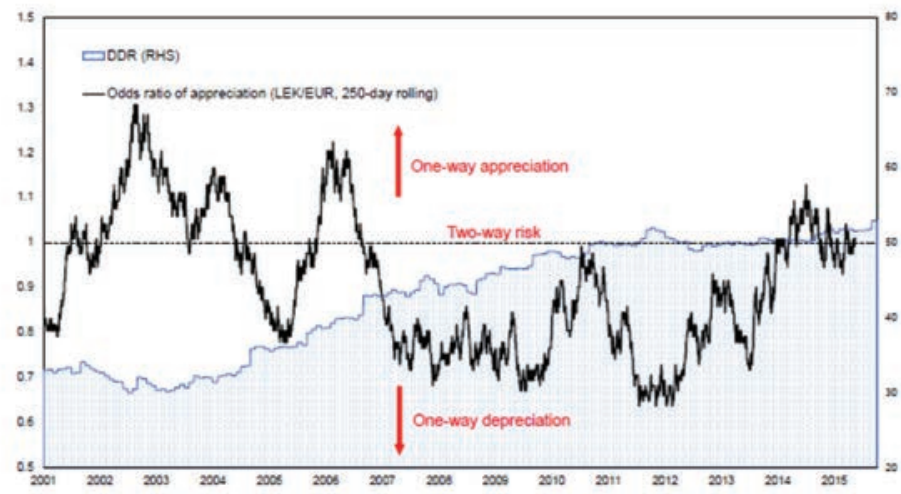

It should be noted that in Albania the odds have been close to one during the past five years, meaning that the public should have equal expectation of exchange rate appreciation or depreciation. This means that the public should perceive two-way risk in the foreign exchange market and, therefore, the hedging value of FX assets should have declined. As a result, the share of euro deposit increased when the odds of a depreciation were high, but stabilized when twoway risk was introduced in the market.

\section{PHASE 2: WHY WOULD EURO NEGATIVE INTEREST RATES MATTER FOR DE-EUROIZATION?}

So let's move from phase 1 to phase 2 .

Here it is a question of foreign currency deposit as an insurance and what premium is paid. To encourage domestic currency intermediation, the intermediation spread in domestic currency should narrow vis-à-vis the intermediation spread in foreign currency so as to make domestic currency deposits and loans relatively more attractive financially vis-àvis foreign currency deposits and loans. It is here that the negative euro 
Figure 4. Euro negative interest rates and de-euroization

Phase 2. Why would euro negative interest rates matter for de-euroization?

Narrow FX intermediation spread

. FX loan index to EURIBOR

Deposit floored at zero and high

reliance on deposit funding

FX deposits often involuntarily

subsidized at low rates via

regulation and reserve requirement

Reduced euro deposit insurance cost

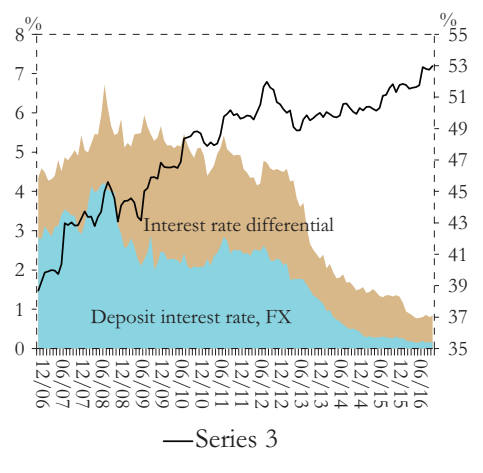

interest rates are creating a problem from the perspective of leaning against and fighting excessive euroization. Why? First of all, euro loans are cheap because FX loans are mostly indexed to Euribor, and now Euribor is in a negative territory or very low. But, on the other hand, the negative rate is usually not passed onto euro deposits, especially on retail deposits.

What we noticed in the euro area is that negative rate transmitted very well to the money market, but not to retail funding. For Albania's banking sector, which is mainly financed by retail deposits, zero is the floor and deposit rates did not follow the euro area money market rates. As a result, the foreign currency intermediation spread is compressed compared to the local currency intermediation spread, encouraging financial euroization.

Regulations preventing negative remuneration of customer deposits, - as well as the practice of many central banks in the Western Balkans to not pass the negative remuneration of their euro reserves on banks' accounts with the central bank - contributed to the relative compression of the intermediation spread. 
So, what can we do? It is important to try to correct the relative mispricing of the foreign exchange deposits. The first priority is to leave it to the banks to decide whether and how to pass the negative rates to customers. What we have seen in the euro area is that banks themselves would not pass a negative rate if they felt they would be losing funding. Therefore, it is better to let them decide to which type of clients they can pass the negative rates.

The second important aspect is to pass the negative rate to bank accounts at the central bank, including the reserve requirements, to avoid subsidizing euro deposits in the banking sector. This is what the Bank of Albania did recently.

It is also important to recall what is the role of reserve requirement on foreign currency deposits. It is mainly prudential: the idea is to make sure that the banks keep a certain amount of high-quality liquid assets at the central bank always available to back up their euro deposits. This is important because the deposit guarantees will never have as many resources as the reserve requirements to back up euro deposits. It also forces banks to contribute to the reserve buildup at the central bank to provide emergency liquidity assistance in foreign currency, and it transfers the cost of the reserve build up to the banks, which in turn forces them to internalize the risk of foreign exchange intermediation. In that case, the central bank just acts as an intermediary collecting euros from the banking sector and investing them in the euro area money market in high-quality liquid assets.

That also justifies why the euro area money market interest rate should be transmitted to the reserve requirement remuneration. One other measure that is often applied is to discriminate in terms of the reserve requirement ratio between foreign currency and local currency to have an impact on banks' cost of funding in favor of the local currency. It is important to have the right remuneration structure if you decide to differentiate between your reserve requirement ratio to avoid encouraging the collection of foreign currency deposit by remunerating the reserve requirement on foreign currency deposits above the market rate. 
The last point to consider is adjusting the reserve requirement ratio depending on each bank contribution to euroization. This is also envisaged to be implemented by the Bank of Albania. For instance, a higher reserve requirement ratio could be applied to banks that have a percentage of foreign currency deposits higher than the rest of the industry, as they contribute more than others to financial euroization or, as planned in Albania, to apply a higher and more penalizing ratio on the amount of foreign currency deposits exceeding a certain critical threshold (for example, a higher ratio on FX deposits exceeding 50 percent or 40 percent of total deposits).

\section{PHASE 3: PORTFOLIO OPTIMIZATION}

The last phase to address in the euroization life cycle is probably the most challenging for a small open economy. This phase is when euroization is driven by portfolio optimization considerations. The left-hand side of Figure 5, derived from the paper by Alan Ize \& Levy Yeyati, shows the relation between the minimum variance portfolio and deposit euroization.

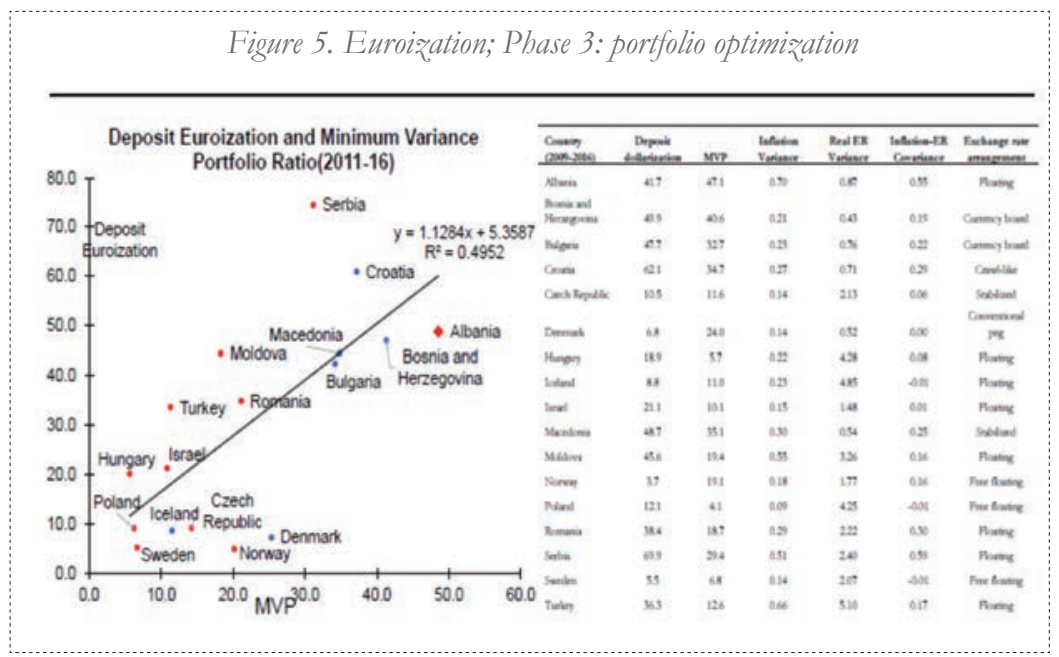

We note from the figure that there is a clearly positive relation between the two. The red dots represent inflation targeters with a flexible exchange arrangement in the Western Balkans. The blue dots are the countries with a fixed exchange rate arrangement. Normally, inflation 
targeters, like Poland, have a low minimum variance portfolio (MVP), and they also have a very low level of euroization. What is surprising is that, for instance, Albania has a relatively high minimum variance portfolio, which is largely because there is a high covariance between inflation and the exchange rate. So here we go back to the natural level of euroization: when you are a small open economy, you have a large pass-through, and then you create a link between the exchange rate and inflation. It is therefore more difficult to reduce the minimum variance portfolio. Another difficulty is that the pass-through is usually higher in countries that are highly euroized.

\section{PHASE 4: PRE-CONDITION FOR MORE EXCHANGE RATE}

\section{VOLATILITY}

In this phase, the priority is to tackle the risk due to unhedged foreign exchange lending, which should reduce the fear of floating and, thus, facilitate the move toward inflation targeting and a flexible exchange rate.

The first order of business is to identify those borrowers who have a natural hedge against exchange rate swings, such as exporters, and those who are to a large extent unhedged. For this, a standardized and compulsory definition of unhedged borrowers for the banks is needed. Then, the first line of defense is to ask un-hedged borrowers to have enough income relative to debt to be able to absorb potential increases in regular debt servicing installments as a consequence of exchange rate depreciation. This means imposing a limit to the maximum debt service-to-income ratio. The second line of defense is to ask the banks to have larger capital buffers to absorb the risk of non-performing loans in case of exchange rate depreciation due to unhedged borrowing. This may take place, for instance, by parametrizing the counter cyclical capital buffers on the basis of the share of unhedged borrowers in foreign currency to boost the loss-absorption capacity of banks with large indirect exposure to exchange rate risk. Alternatively the central bank could impose higher risk weight on unhedged FX lending to increase capital buffers, but also to discourage the provision of loans to unhedged borrowers. 
This page intentionally left blank 


\title{
SECOND SESSION: \\ NEGATIVE EURO AREA INTEREST \\ RATES AND FINANCIAL \\ STABILITY IN WESTERN BALKAN \\ ECONOMIES
}

\author{
Moderator: Natasha Ahmetaj \\ Bank of Albania, Second Deputy Governor
}


This page intentionally left blank 


\title{
INTRODUCTORY REMARKS: PANEL ON "NEGATIVE EURO AREA INTEREST RATES AND FINANCIAL STABILITY IN WESTERN BALKAN ECONOMIES"
}

\author{
Natasha Abmetaj \\ Bank of Albania, Second Deputy Governor
}

Thank you again for coming back to the second session. In this session, we will continue to discuss the negative euro area interest rates and financial stability in our respective countries.

The composition of this panel is very interesting, because now we have the representatives of Western Balkan countries. This panel composition will give us the opportunity to see from an insider's perspective the correlation between the negative interest rates environment and financial stability in the Western Balkans.

Eased monetary conditions are very classical ingredients for financial crises. This relation acquires a new and interesting dimension since we are now talking not just low interest rates, but negative interest rates. The subject is more often present in the debates regarding the correlation between low interest rates and the risk-taking channel, which is the so-called monetary policy risk-taking channel. It is increasingly becoming an accepted postulate of the economic doctrine that, yes, there is a very strong correlation between very low and for too long interest rates and this risk-taking channel.

Because interest rates are not just low, but negative, this sensitivity is supposed to be stronger. In addition, there are other conditions, which might be of a national or global development nature, based on which this correlation may take a new and bespoke pattern. For more details on this correlation, Mr. Klodion Shehu, the Head of the Financial Stability at the Bank of Albania, will share with us his perspective on the implication of low interest rates for financial stability in Albania. 
This page intentionally left blank 


\section{IMPLICATIONS OF LOW INTEREST RATES FOR FINANCIAL STABILITY IN ALBANIA}

\section{Klodion Shehu \\ Bank of Albania, Financial Stability Department, Director}

I would like to start by saying that lower interest rates reflect a longterm pattern that has been taking place for longer than one might think. We relate lower interest rates to global financial crises, but, the left-hand chart of Figure 1 shows that global interest rates have been declining for many years and decades. This trend is, perhaps, related to fundamental factors. There are two prevailing views. According to the first view, structural factors have pushed interest rates to record low levels. These structural factors include demographics and longer life expectancy. This affects their propensity to save and invest. In addition, there are, for example, developments related to China, becoming much more important in the world economy and much more financially integrated.

On the other hand, there are others who think that lower interest rates are a cyclical phenomenon, in which lower interest rates are a reaction to the high leverage levels, which contributed to the global financial crisis. According to this view, lower interest rates are necessary to facilitate the deleveraging process, thereby they are expected to return to normal, in the future, when the deleveraging process will have been completed.

Since there is no conclusive answer, yet, it is better to prepare for both scenarios. Obviously, for the financial system and financial stability, it matters whether low interest rates are here for long, or they are going to return to more normal levels.

The right hand chart of Figure 1 shows that there is an investors' preference for longer portfolio in parallel to the decline of the government debt yields in the Japan, UK, and US. 
1: 10-yr sovereign bond yields, selected EU countries (\%)

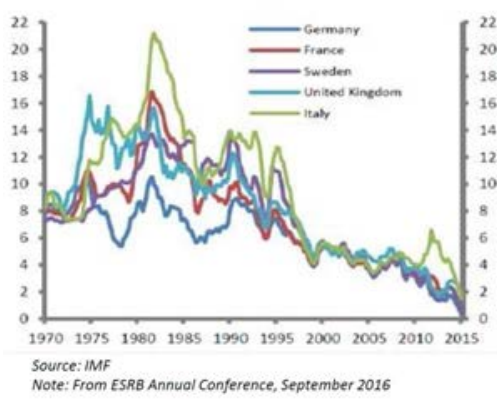

2: Global Bond Portfolio Duration

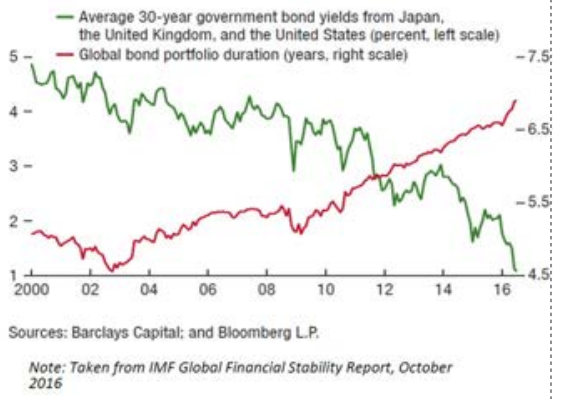

This shows that there is a high propensity to save and invest in safer assets. Table 1 summarizes the implications of the low interest rates environment for financial stability. The first impact is obviously on banks' profitability. As long as the interest rates go down, especially if intermediation spreads narrow, the net interest income declines. But, on the other hand, lower interest rates could also help borrowers' debt servicing capabilities and lower default probability. The net effect is difficult to predict, as it depends whether the net interest income effect or the NPLs effect prevails.

Table 1. How low interest rates affect financial stability

\begin{tabular}{|c|c|c|c|c|}
\hline $\begin{array}{l}\text { Impact from Low } \\
\text { Intarest Rnte } \\
\text { Envitonment in: }\end{array}$ & Banke & $\begin{array}{l}\text { Other Financial } \\
\text { Institutions }\end{array}$ & Private non-financial entities & Markats \\
\hline Profitability & $\begin{array}{l}\text { Net interest Income: } \\
\text { Lower Net Interest Margins (more } \\
\text { sensitive for those with higher } \\
\text { weights of deposits in liabilities; } \\
\text { inflexible cost structure) }\end{array}$ & $\begin{array}{l}\text { Net interest Income: } \\
\text { Insurance/Pension Funds: } \\
\text { Guaranteed return / defined } \\
\text { benefits } \\
\text { (more sensitive for Uife } \\
\text { insurance companies) }\end{array}$ & $\begin{array}{l}\text { Reducing debt servicing costs, } \\
\text { hence improving } \\
\text { profitability/viability for existing } \\
\text { borrowers; } \\
\text { possible lower incomes for savers. }\end{array}$ & $\begin{array}{l}\text { Increasing duration, possibly } \\
\text { higher asset (financial and } \\
\text { real asset) prices; }\end{array}$ \\
\hline Possible mitigation & $\begin{array}{l}\text { Search for yields; } \\
\text { Increasing fee-generating } \\
\text { products/services; further cost } \\
\text { cutting }\end{array}$ & $\begin{array}{l}\text { Moving toward interest rate- } \\
\text { linked products }\end{array}$ & & \\
\hline Risk Taking & $\begin{array}{l}\text { Possibly higher investment/assets } \\
\text { risk; } \\
\text { funding structure risk; } \\
\text { risks to viability. }\end{array}$ & Similar to banks & $\begin{array}{l}\text { More exposed to market risk: } \\
\text { Increasing leverage for new } \\
\text { borrowers (debt-to-income, debt- } \\
\text { to-capital could deteriorate quickly) }\end{array}$ & $\begin{array}{l}\text { Higher concentration on } \\
\text { investment assets; } \\
\text { more interconnected system' } \\
\text { possibly higher systemic risk }\end{array}$ \\
\hline $\begin{array}{l}\text { Structural } \\
\text { changes }\end{array}$ & $\begin{array}{l}\text { Lower profitability (expectation) } \\
\text { could induce efforts to } \\
\text { divest/consolidate }\end{array}$ & $\begin{array}{l}\text { Newcomers, with more } \\
\text { competitive cost structure } \\
\text { could join in. }\end{array}$ & $\begin{array}{l}\text { More interest to raise finance } \\
\text { directly in the market }\end{array}$ & $\begin{array}{l}\text { Move toward a more market- } \\
\text { based system }\end{array}$ \\
\hline $\begin{array}{l}\text { Challenges for } \\
\text { regulators }\end{array}$ & $\begin{array}{l}\text { How to balance/prioritize between } \\
\text { higher copital needs, with lower } \\
\text { profitability and (possibly) lower } \\
\text { financial intermediation? } \\
\text { How to ensure orderly exits and } \\
\text { valid new-entronts in the market? }\end{array}$ & $\begin{array}{l}\text { Is there a need and how to } \\
\text { adjust the supervisory } \\
\text { perimeter? } \\
\text { What about possible } \\
\text { (unreguloted and) unfair } \\
\text { competition? }\end{array}$ & $\begin{array}{l}\text { How to effectively reach } \\
\text { households/firms and alert about } \\
\text { risks? How to ensure sufficient } \\
\text { transporency on prices of financial } \\
\text { services? How to meet the need to } \\
\text { collect better dato from the real } \\
\text { sector? }\end{array}$ & $\begin{array}{l}\text { How to improve rules, } \\
\text { procedures, inter-institutional } \\
\text { coordination to accommadote } \\
\text { for possibly increasing } \\
\text { systemic risk? }\end{array}$ \\
\hline
\end{tabular}


Obviously, the effect also depends on the composition of banks' liabilities. Given the zero lower bound on deposits' remuneration, the net interest income effect may prevail for banks relying to a greater extent on customers' deposits as opposed to wholesale funding.

Other financial institutions may also find it difficult to cope with lower interest rates. Some of these institutions provide guaranteed return or defined benefits, for example, insurances or pension funds, and, if returns on assets decline, they have difficulties honoring their liabilities. This is especially true for life insurance companies.

Regarding private non-financial entities, the lower interest rates are to some extent positive, because they reduce the debt servicing costs, and hence improve the profitability and viability of existing borrowers. On the other hand, they also provide lower income for savers.

Regarding the risk-taking behavior, in markets with lower interest rates, lower returns could encourage taking longer duration positions and, possibly, underpin higher financial and real asset prices. Banks may compensate the lower yields on their financial assets with longer duration and may expand their fee-generating services. Obviously, they could also cut costs, up to a certain point. This low-interest environment, therefore, encourages banks to compensate lower yields and lower margins with greater volumes and riskier investments.

Banks are also exposed to a funding structure risk, which relates to the structure of their liabilities, short-term, longer term, and how stable it is and, again, if the profitability is a problem, this could also translate into risk shifting.

Non-bank financial institutions are exposed to the same risks of banks. Private non-financial entities could be more exposed to market risk, and also, for new borrowers, there could be a risk of higher leverage as measured by the debt-to-income or debt-to-capital levels.

In financial markets, there could be higher concentration on investment assets, meaning, for example, government debt, and a more interconnected system because there is a larger concentration so that systemic risk may increase. There might also be structural changes because of low interest rates. This could relate with low 
profitability or expectations of lower future profitability. This could induce efforts to divest or consolidate, and also there might be competition from newcomers to the market, which could have structural advantages and challenge the existing players. There could be more interest from private non-financial firms to raise finance directly in the market, especially if there are greater bank lending constraints. Therefore, there could be a move toward a more marketbased financial system.

All this could provide challenges for regulators. These are some of the challenges that I included in Table 1. For example, for banks, the challenge is how to balance or how to prioritize the higher capital needs with lower profitability in a context in which it is desirable for them to continue financial intermediation. The challenge is also how to manage a market restructuring process to ensure an orderly exit of banks willing to divest and the smooth entry of newcomers. There is also the question of supervisory perimeter. These newcomers could be unregulated, so that they need to be regulated. The balance has to be found there as well, and competition is also an issue that could come up.

About private non-financial entities, companies could find the situation very accommodative, they could increase leverage, and there should be an effort to make them aware of the risks incurred. Banks may compensate lower interest income with higher commissions income from fee-generating services. The terms of these services are not always transparent to the customers. This may require better bank data-collection capabilities from regulators to monitor these policies.

In terms of a possible increase in systemic risks, this is a question that calls for better coordination among regulators in any particular country.

If we now turn our attention to Albania, we see that interest rates in Albania have been declining. Figure 2 shows interbank interest rates, the policy rate of the central bank, which has declined since 2012, and its transmission to the government bond yields in the primary market, which have also declined for all maturities. 


\section{Interest rates in Albania}

- they have been declining to reflect overall economic conditions and subdued inflationary pressures;

- but there is still space, if needed.

1 .

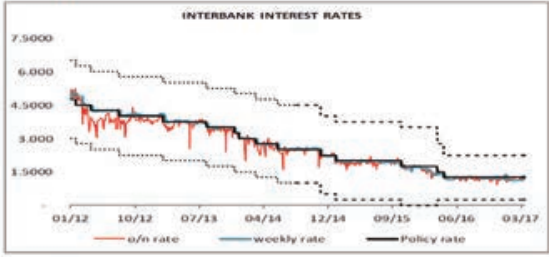

3.

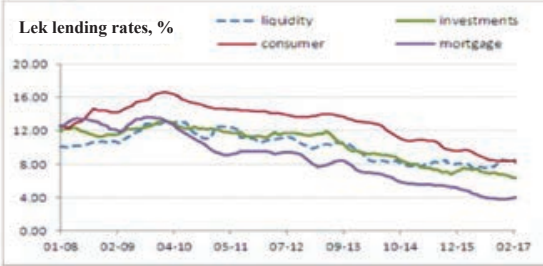

2.

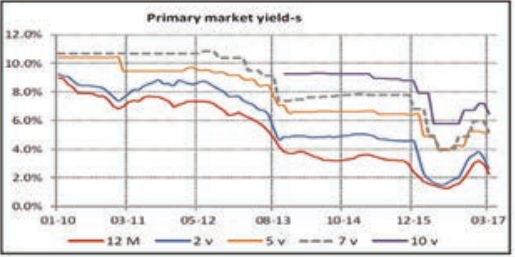

4 -

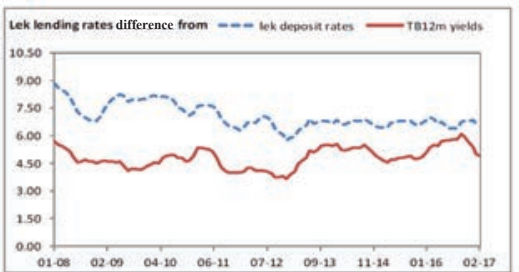

Chart 3 of Figure 2 shows the lek lending rates for different types of loans. They have reflected the monetary policy accommodation of the central bank. Chart 4 shows the difference between lek lending rates and lek deposits rates. The blue line shows a narrowing intermediation spread, while there is a more stable difference between lek lending rate and T-bill rate.

Regarding the profitability of the Albanian banking sector, so far, the sector has been profitable during all these years and the operating income has remained broadly stable. Banks have been able to compensate, to some extent, their lower net interest income with lower operating expenses. Chart 3 in figure 3 shows that the blue column is decreasing in terms of weight to risk weighted assets, so does the green column, which narrows as well. This means that, so far, banks have been able to reduce operating expenses to keep their cost-to-income ratio steady. This doesn't include provisions. Provisions are the purple column, which also has an impact on the net financial results. In conclusion, banks, so far, have been able to accommodate the lower net interest income with lower operating costs and lower provisions. 
Figure 3. Profitability of the Albanian banking sector

- the banking sector has been profitable and, so far, able to reduce activity costs to compensate for lower revenues;

- the NNII has not changed noticeably;
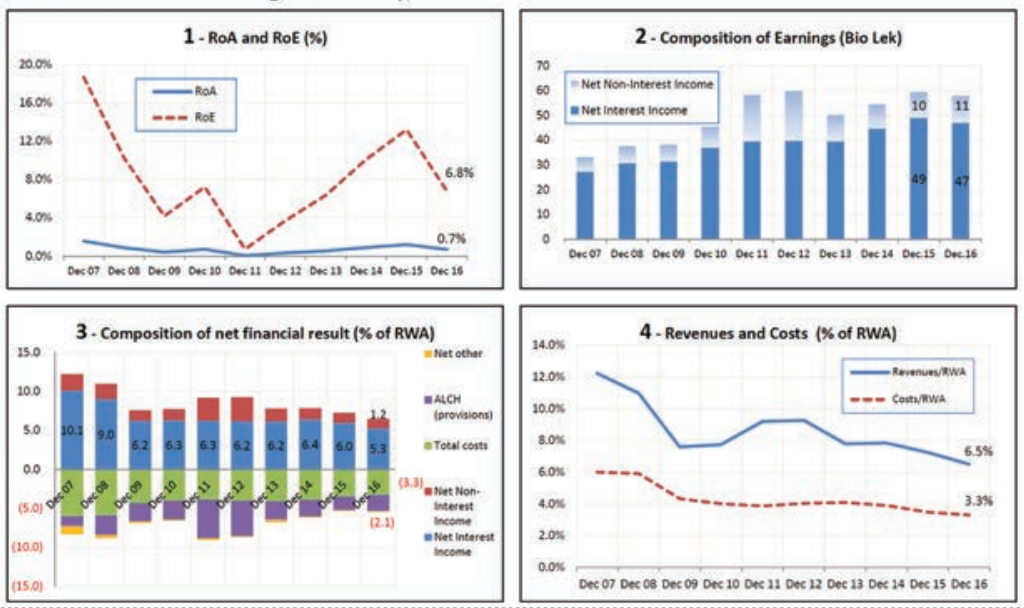

In the meantime, the sector has remained well capitalized, with a capital adequacy ratio of 15.7 percent. The minimum is 12 percent. Figure 4 is an effort to distinguish between the nine subsidiaries of EU-headquartered banks operating in Albania, four subsidiaries of non-EU banks, and the three Albanian banks.

Figure 4. Profitability for the Albanian banking sector (cont.)

Non-EU banks: lower NII have been followed with lower Costs and Provisions;

EU and Alb banks: have seen stable or rising NII, with similar trends in Costs and Provisions.
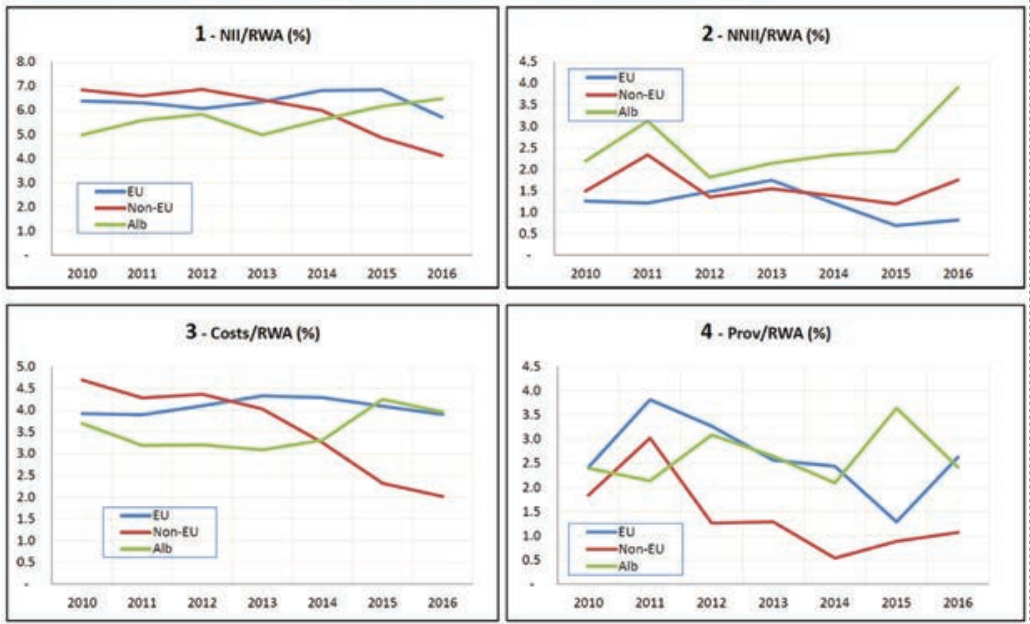
Figure 4 shows that the subsidiaries of non-EU banks experience the sharpest decline in the net interest income in terms of risk-weighted assets, but graph 3 of Figure 4 also shows that in addition, these banks have also been more successful in containing their operating costs as a share of risk-weighted assets.

In terms of risk-taking, one of the purposes of the low-interest rate environment is to encourage extra risk-taking in a context of heightened risk aversion. The problem could be if the low interest rate enviroment persists for too long as it could induce excessive risk-taking. This could take place in several ways: the build-up of leverage; the search of yield, both for banks and for investors; unsustainable higher asset prices, both financial and real estate assets; and also a misallocation of capital and the ability of banks to continue maturity transformation.

The sensitivity for banks could be higher given the possible changes in the funding structure and also changes in currency composition of the balance sheet and the rising exposure to market risks. For example, figure 5 shows what we see in terms of leverage of the banking sector in Albania. Leverage is relatively stable.

\section{Figure 5. Banks: build up of leverage/ search for yield}

\section{- leverage has been stable, weight of investment in Sec and Treasury \&Interbank Transactions (TIT) have increased; duration of (risk free) Gov't securities portfolio has also increased.}

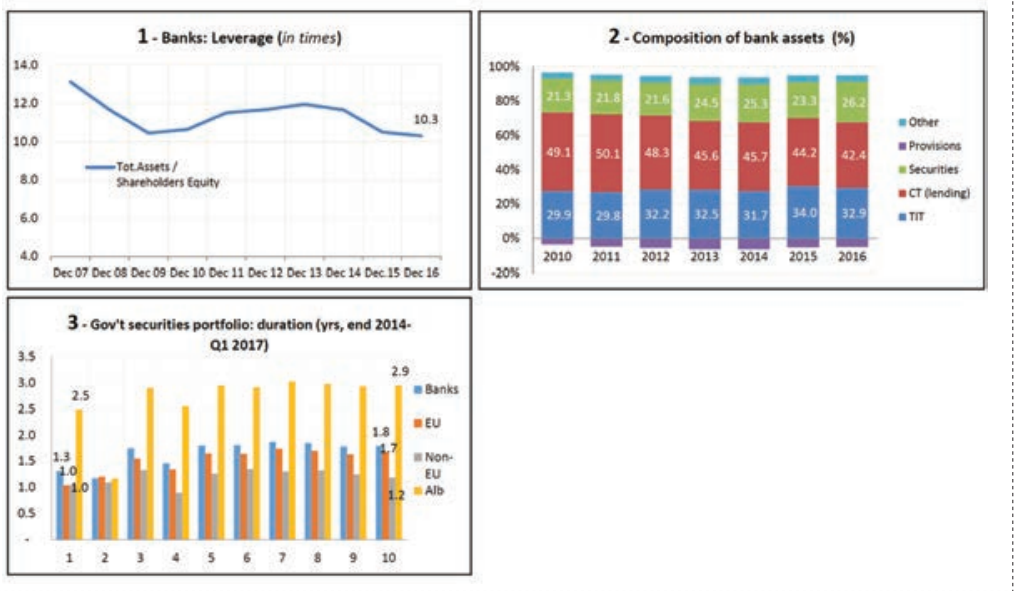


Chart 1 of Figure 5 shows the ratio of total assets to shareholders' equity. If we look at the composition of assets, we can notice, for example, that there is an increase in the weight of transactions in securities and also in treasury and interbank transactions. Chart 3 shows that the duration of the so-called risk-free government securities portfolio has also increased for the entire system. It has gone from 1.3 years to around 1.8 years. The largest increase is noticeable for EU banks and for Albanian banks.

Figure 6 focuses on households and non-financial firms. We get this data from the survey that we conduct every six months with households and non-financial firms to understand their debt burden. Chart 1 of Figure 6 shows that the weight of indebted households has not changed since 2010 .

If we also notice the distribution of monthly debt payments to income ratio, it shows that the debt servicing costs have increased as a proportion of monthly income. The proportion of households with debt servicing costs to income between 31 percent and 50 percent has increased from 9.2 percent to around 27.3 percent.

In terms of non-financial firms' indebtedness, the ratio of indebted firms has steadily declined since the first semester of 2014. This may reflect, for example, the banking sector lending constrains on non-financial firms, but it could also reflect the improvement of the non-financial firms' liquidity position, so that they can fulfill their financing needs with their own resources. Chart 4 shows the distribution of debt payment to revenues for non-financial firms. There is also an increase here, but it is minimal.

Figure 7 looks at the duration of the portfolio of financial assets of households and non-financial firms. There is a slight increase from 1.46 to 1.53 for households, while the duration for non-financial firms has remained stable over time. 
Figure 6. Households (HH) and non-financial (NF) firms: build up of leverage / search for yield

- the weight of Families that has a debt to pay is stable, debt affordability remains at good levels, although debt payment to income is somewhat increasing;

- the weight of NF-Firms indebted is not showing an increase, and the affordability of the debt remains stable.
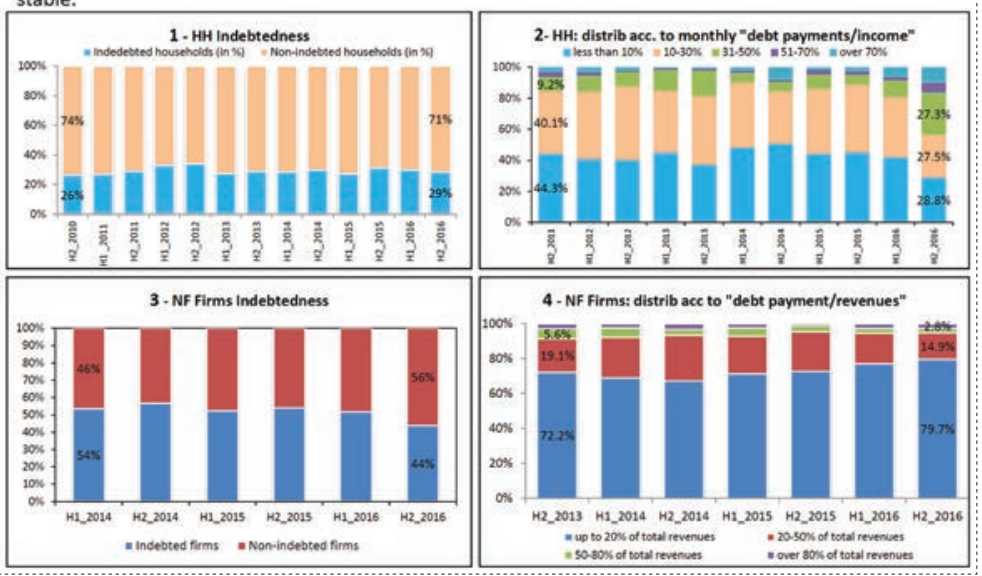

But if we look at households' deposits with the banking sector, we notice an increase in their deposits with a maturity over two years to compensate for lower deposit rates with the higher yield pickup provided by longer-dated deposits.

Figure 7. Housebolds and non-financial firms: build up of leverage / search for yield (cont.) - there is an increase in bank lending to $\mathrm{HH}$, which at the end of 2016 was 3.7\%; for resident NF-firms this figure was slightly negative;

- but there hasn't been any concerning shift in duration of investment from both HH and NF-Firms;

- $\mathrm{HH}$ have been active in increasing the duration of bank deposits and in shifting toward Gov't sec and investment funds
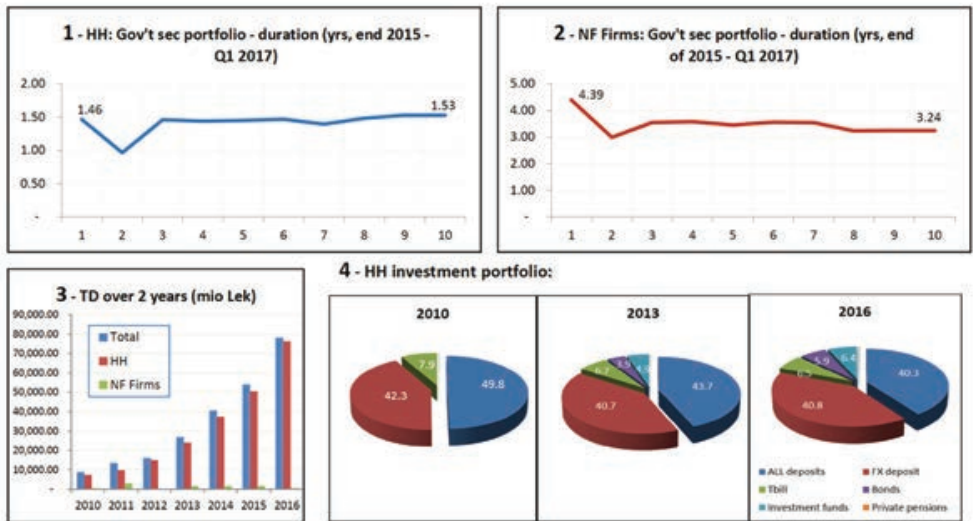
Chart 4 of Figure 7 shows the overall investment portfolio composition of households. We notice an increase of their investments in government securities.

In terms of asset prices, lower interest rates have been reflected in lower government bond yields and corresponding higher prices, as evidenced in chart 1 of Figure 8. However, chart 2 shows that the declining yields have coincided with lower government borrowing in the past two years so that rising prices also reflect the lower government financing needs.

In terms of real assets, the results of two Bank of Albania's surveys show that the real estate prices have remained at the end of 2016 broadly at the same level recorded at the beginning of 2013 .

\section{Figure 8. Asset prices: trends}

- there is a decline in yields/rise in prices of Gov't debt;

- but in addition to lower interest rates, it also reflects the lower borrowing demand from the Gov't.

- the real estate prices do not show a clear trend.

\section{Financial assets}
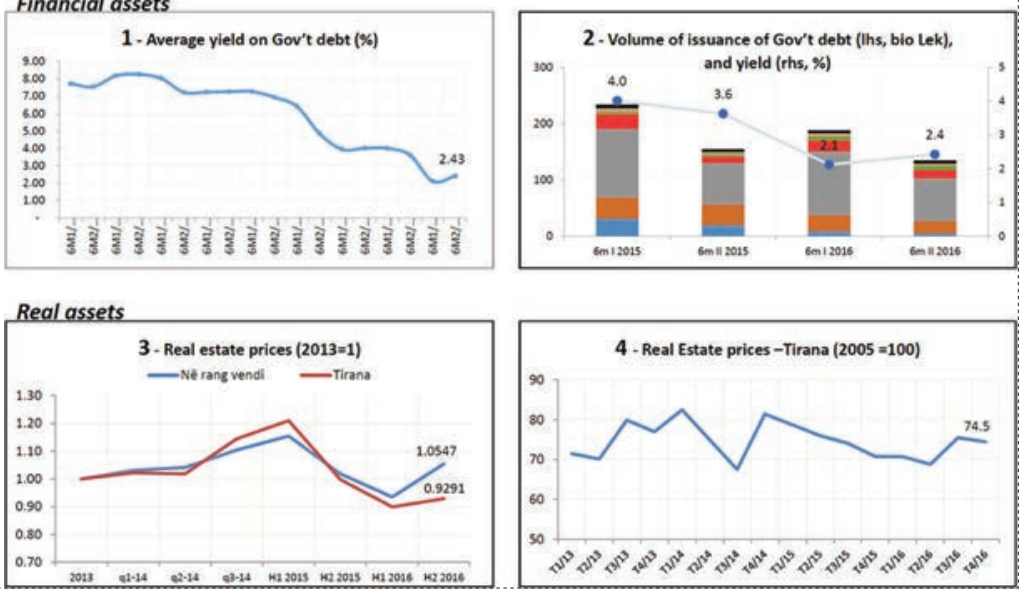

In terms of maturity transformation, as shown in Figure 9, growth in banks' deposits has funded mostly investments in securities and treasury operations, especially with non-residents. The deposit structure shows, as evidenced in chart 3 of Figure 9, a decline in the weight of time deposits and the rising weights of current accounts and saving accounts. 
Figure 9. Banks: maturity transformation

- growth in deposits, has gone mostly to investments in securities and treasury operations, especially with nonresidents;

- changes in deposit structure are showing a decline in the weight of TD, and a rise in weights of CA and SA;

- within the TD, there is a trend to go longer than 2 years in maturity;

- financial intermediation to PS should become more difficult as the funding becomes shorter in maturity
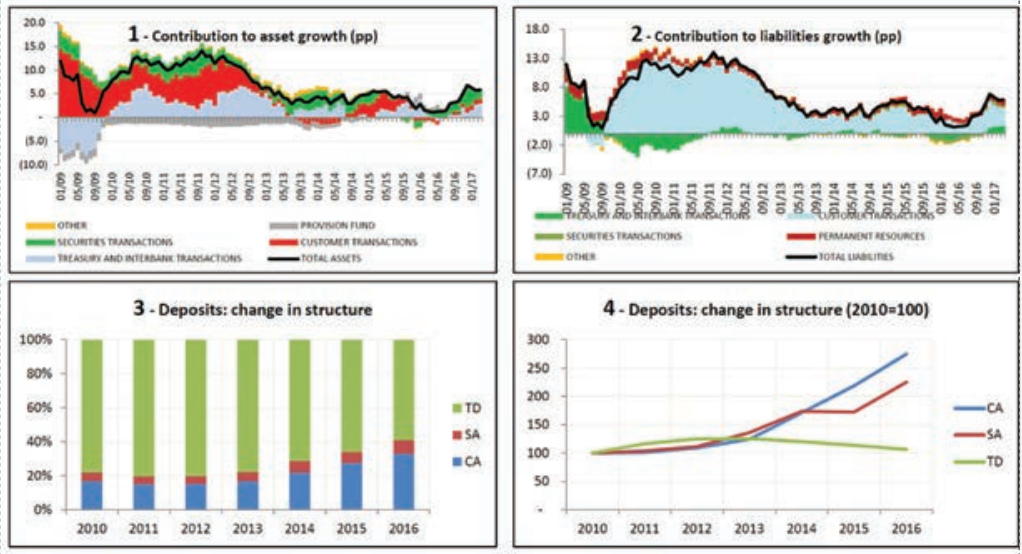

Despite these changes, the weighted average maturity of banks' assets and liabilities has not significantly changed, as evidenced in Figure 10. The loan-to-deposit ratio has marginally increased, but remains at very low levels compared to other countries in the region and EU banks.

\section{Figure 10. Banks: maturity transformation}

- banks have been able to keep stable average maturity for assets and liabilities;

- overall credit remains subdued, and credit to deposit ratio remains low;

- the rise in RWA is gradual and also reflects regulatory measures;

- although the investments in RFA remain contained, their duration (gov't) should be rising;
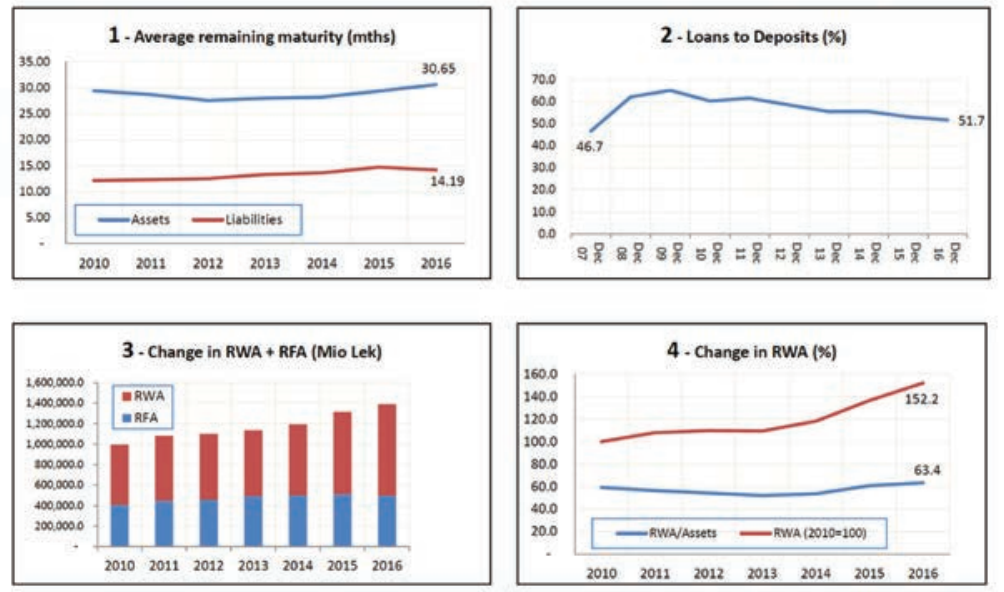
Chart 3 of Figure 10 shows the change in risk-weighted assets and in the risk-free government debt assets. It displays an increase in riskweighted assets, which might be interpreted as a pursuit of higher returns via extra risk-taking. This is also confirmed by chart 4 .

Figure 11 breaks down the changes in risk-weighted assets between EU banks, non-EU banks, and Albanian banks. Chart 1 shows that risk-weighted assets of subsidiaries of EU banks have been mostly stable. Therefore, the increase in the banking sectors risk-weighted assets can be almost exclusively attributed to Albanian banks and to subsidiaries of non-EU banks.

\section{Figure 11. Banks: Risk-weighted assets}

-EU banks more passive, both in terms of investment in RWA and RFA; - Non-EU banks, show a rise in RWA but stable investments in RFA; - Alb banks, show a rise in RWA and in RFA

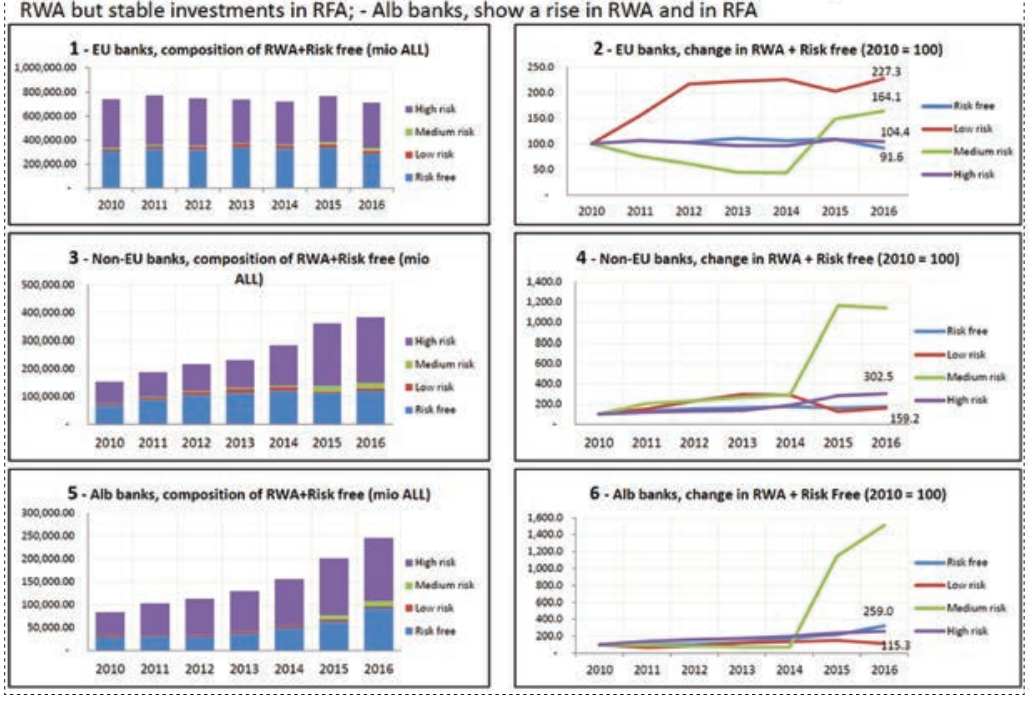

In terms of asset quality, one might expect that banks would use the benign interest rate environment to improve asset quality and restructure existing, impaired loans. Figure 12 shows that there has been an improvement in the NPL ratio for both foreign currency and domestic currency loans. However, such improvement largely reflects approximately 40 billion lek of non-performing loans written off in the past two years, while it is still unclear whether the lower NPL ratio also reflects an effective improvement in the quality of the lending portfolio. 


\section{Banks: quality of assets: Have banks used the low interest rate environment to improve on their loan quality?}

- Low interest rates, in combination with appropriate restructuring of NPLs, should help to effectively improve the quality of loan portfolio and resolve NPLs;

- The NPLR, has declined from a peak of $25 \%$ in Sept.2014, to around $17.4 \%$ in March 2017;

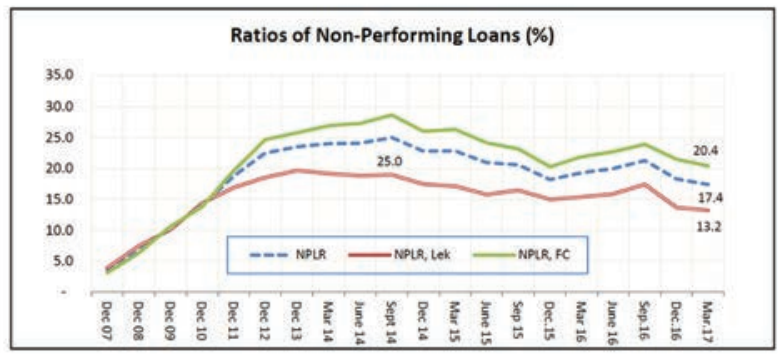

- But the write-off of approximately 40 billion All in "lost" loans over the last 2 years, has given the main impact in improvement;

As it was mentioned in the previous session, low interest rates have also had effects on the currency composition of the banks' balance sheet. Chart 1 of Figure 13 evidences that deposit growth is almost exclusively driven by foreign currency deposits, whereas chart 2 shows that lending mostly happens in domestic currency, while it is contracting in foreign currency.

Figure 13. Banks: changes in currency composition of the balance sheet - Lower interest rates for Lek lending, and lower spreads between Lek and FX interest rates for deposits, have contributed to higher growth in Lek Loans and Fx deposits;

- higher FX deposits, while FX lending has declined, has gone mostly for investments abroad;

- nevertheless, higher $\mathrm{Fx}$ deposits represents higher liquidity risk and possible source of Fx lending revival when conditions are more favourable;
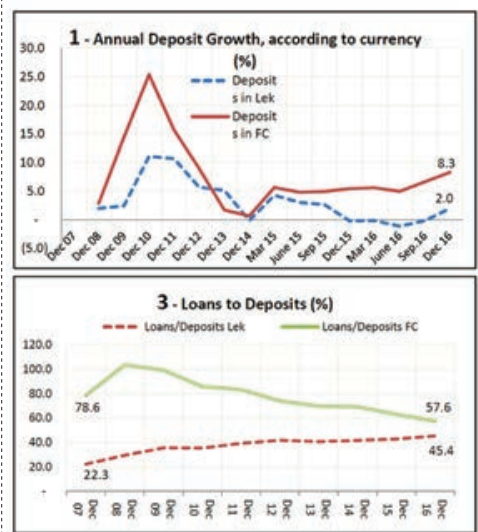
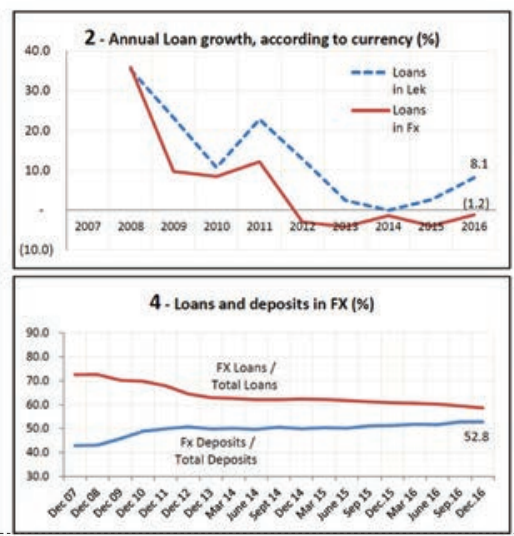
This has changed the loan-to-deposit ratio in lek and in foreign currency. The loan-to-deposit ratio in lek has risen from 22.3 percent 10 years ago to around 45 percent. In terms of loans and deposits in foreign currency, foreign currency loans now stand at 58.6 percent of total loans, foreign currency deposits have increased to around 53 percent of total deposits.

This brings us to the issue of unhedged foreign currency credit. Figure 14 shows that since the end of 2014, unhedged loans have been declining with a stabilization observed in 2016. However, the recent growth of foreign currency deposits could fuel foreign currency lending, which would be worrisome. Figure 14 shows the composition of foreign currency unhedged loans between different segments. Around three-quarters of unhedged loans are placed with non-financial firms, which may be better equipped than households to withstand exchange rate fluctuations.

\section{Figure 14. Banks unhedged foreign currency credit}

- this portfolio has been declining until 2015, and then stabilizing in 2016;

$-3 / 4$ of this portfolio is held by Firms.
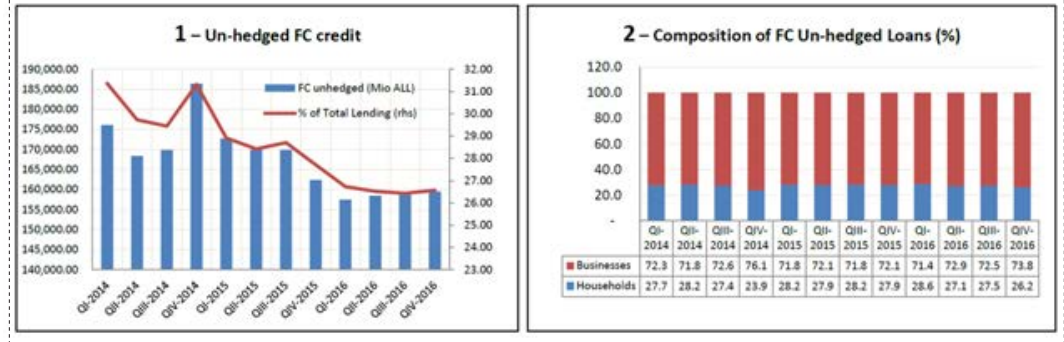

Increasing foreign currency deposits with stable foreign currency lending has challenged the banks to find suitable foreign currency investment opportunities. One of them has been increasing placements with non-residents. Figure 15 shows that claims on non-residents have increased to around 27 percent of total assets, while liabilities toward non-residents have remained very limited. If we look at the geographical distribution of placements, claims on non-residents are mainly deposits placed with non-resident financial institutions. Placements with the euro area have declined, while 
placements with non-EU countries have increased. This may reflect the pursuit of higher returns in a low-interest rate environment, but it remains a concentrated phenomenon. The higher placements with non-EU residents reflect the policies of just a couple of banks.

\section{Figure 15. Banks: transactions with non-residents}

- in Placements, there has been an increase toward investment with FI from non-EU countries; - in Securities, the weight of investments in Euro has increased while that in USD has decreased - Credit to nonresidents has increased to $11.3 \%$ of Total Loans;
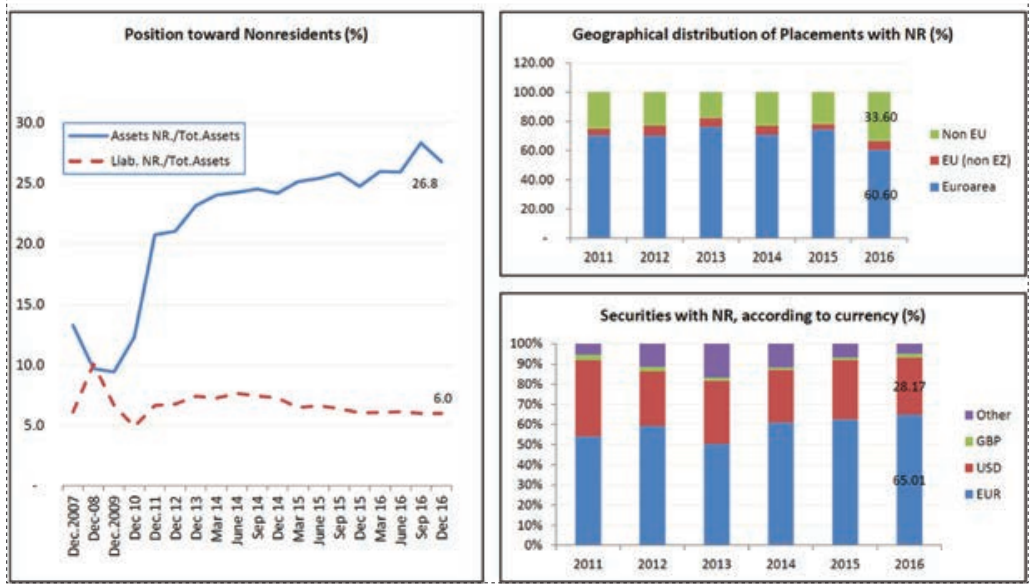

In terms of portfolio investment in foreign currency, we see that the weight of euro investments has marginally increased at the expense of the US dollar, whereas other currencies have remained relatively stable.

A low interest rate environment could also bring other structural changes. In the banking sector, we have not yet noticed any increase in the non-interest income generated by fees and commissions. They are relatively stable, which means that banks, in general, are not very active in this regard. Pressure on profitability has been felt in our banks, but, so far, they have withstood it well and have attempted to streamline their operations and increase efficiency levels.

However, profitability concerns could be accentuated in the near future, which, together with the new regulatory landscape in the EU, may exert pressures on EU banks with local subsidiaries to divest or to consolidate. Therefore, we need to remain vigilant, and banks 
should be prepared for different scenarios, both a scenario in which interest rates will continue for longer to remain low, but, especially, for a scenario in which interest rates will rise because this will expose their balance sheets to market risks.

In non-bank financial institutions and in financial markets, we see increasing evidence of market-based financing needs to diversify financing sources away from pure bank-based financing. In the past 18 months, non-financial firms have issued some short-term debt. A private stock exchange is also being established.

These developments provide challenges for regulators and for the financial industry. Therefore, in conclusion, we have a very low interest rate environment, but we don't really know whether this is going to continue for longer or is going to reverse soon. So far, in this environment, the Albanian banking sector has managed to offset lower net interest income with lower costs, so the profitability has been relatively stable. The liabilities of banks are changing both in terms of maturity structure and in terms of currency composition. This is having some impact on their ability to intermediate and on euroization levels. Banks are increasing their portfolio investment toward longer-dated securities, while at the same time, the loans' quality and the NPLs ratio remain problems.

Households and non-financial firms are not increasing their leverage to any concerning level, but they are looking for higher returns on their asset side. Asset prices are relatively stable. Banks are still focused on their core activity. In terms of the rest of the market, there is an increasing preference for more market-based financing, though the trend is just at the beginning. This raises several challenges for the regulators that could be handled with better communication with the industry, especially better information collection and sharing capabilities. Finally, we have to maintain a risk-focused approach for all these developments. 


\section{WHAT IS OBSCURED BY AGGREGATE DATA IN THE CASE OF BOSNIA AND HERZEGOVINA?}

Belma Colaković Central Bank of Bosnia and Herzegovina, Chief Economist

In my presentation, I would like to emphasize some risks to financial stability that are hidden if one observes only the aggregate data. In a sense, I am going to play the devil's advocate. One of the things that I noticed in the reports of the IMF Spring Meetings, and that goes with the general wisdom in the world, is that regarding Central European and Southeastern European countries, their credit cycle position is in an expansionary phase. Several facts are mentioned to underpin this conclusion: credit growth is increasing, bad debt recovery is increasing, NPL ratios are decreasing, asset prices are increasing, and bank profitability is increasing. All correct, with a lot of "BUTs."

I am going to treat some of those "buts" in my presentation, with the general disclaimer: "If I say something that you strongly disagree with, it is not the Central Bank of Bosnia and Herzegovina. It is my fault."

In the first chart, I present financial assets and liabilities, without capital, of the banking sector of Bosnia and Herzegovina and the determinants of net interest income (Figure 1). 
Figure 1. The determinants of net interest income in $\mathrm{BH}$

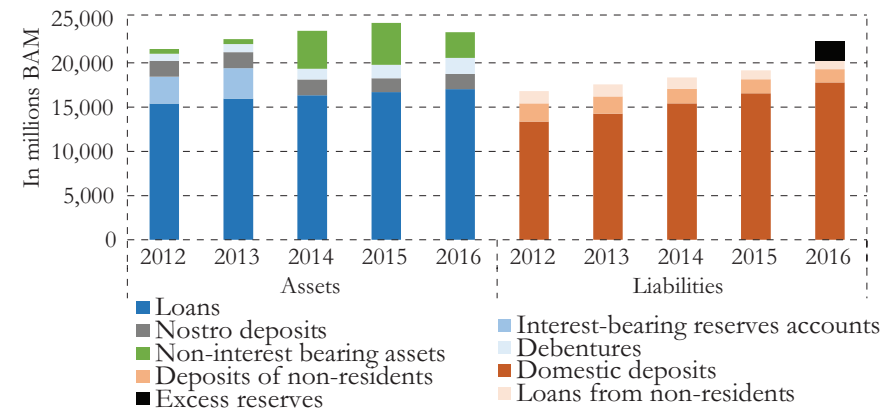

Notes: Depicted are financial assets and liabilities, net of capital. Non-interest bearing assets up to $2013 i$ include cash in vaults; as of 2014, reserves accounts with the CBBH are included. As of 2016, non-interesti bearing assets exclude excess reserves, as the negative remuneration rate on excess reserves has been introduced. 1 For this reason, these are on the liabilities side, although, technically, these are bankss assets. . . . . . . . I

In Figure 1, I showed 2008, which is the peak year, and then I showed all years from 2012 onward. The slide shows what was happening in terms of the banking sector and the changes in balance sheet positions. As one sees, there is a very mild credit growth from 2013 onward. "Nostro accounts" have been fairly stable. Noninterest bearing assets until 2013 are represented exclusively by banknotes and coins. After 2013, they also include required reserve accounts with the central bank for the reason that we lowered the remuneration rate at 0 , while we lowered it below zero for the excess reserves as of 2014 .

On the liability side, there is a strong deleveraging process as evidenced in the chart. Foreign liabilities dropped from 5.5 billion convertible marks in 2008 to approximately 2.2 billion currently. Regarding liabilities, domestic deposits represent the main source of interest expenses for commercial banks, together with excess reserves since 2016. In fact, although excess reserves are commercial banks' assets, they engender an interest rate cost for commercial banks, as banks get charged a negative rate on excess reserves. The chart shows that as of 2014, the interest generating assets are fairly constant while the interest-bearing liabilities of commercial banks are increasing. Required reserves are roughly at the level of 4 billion and there are a few reasons for that. But the main reason, historically, was the regulatory requirements regarding the liquidity risk management. Regarding the network composition of commercial banks, in Bosnia 
and Herzegovina, banking supervision is not the responsibility of the central bank, but of two separate, sub-state level banking agencies that operate under very harmonized rules. Despite the harmonized rules, this structure poses a challenge from the perspective of consolidated reporting to the same foreign banking group. I am going to touch upon domestic deposits later on during my presentation, but they currently represent quite a significant fraction of liabilities of $\mathrm{BH}$ commercial banks. Such funding structure might possibly limit the credit growth in the future, especially if the EU regulation on crossborder exposure of banking groups is taken into account. Currently, commercial banks from the EU have a 100 percent risk weight on their exposure to Bosnia and Herzegovina even for a central bank's reserves. Such a requirement weighs on banks' profitability and, partially, explains the deleveraging trend.

Net interest margin (Figure 2) over the past five years has been fairly constant. I emphasize the fact that interest bearing assets were fairly constant, while liabilities were increasing. Net interest income minus interest expenses is, again, fairly constant. Relating to profitability of commercial banks in Bosnia, one must notice that business and direct expenses are those that drive the profitability of the banking sector in Bosnia and Herzegovina, especially the provision for the losses in the previous period.

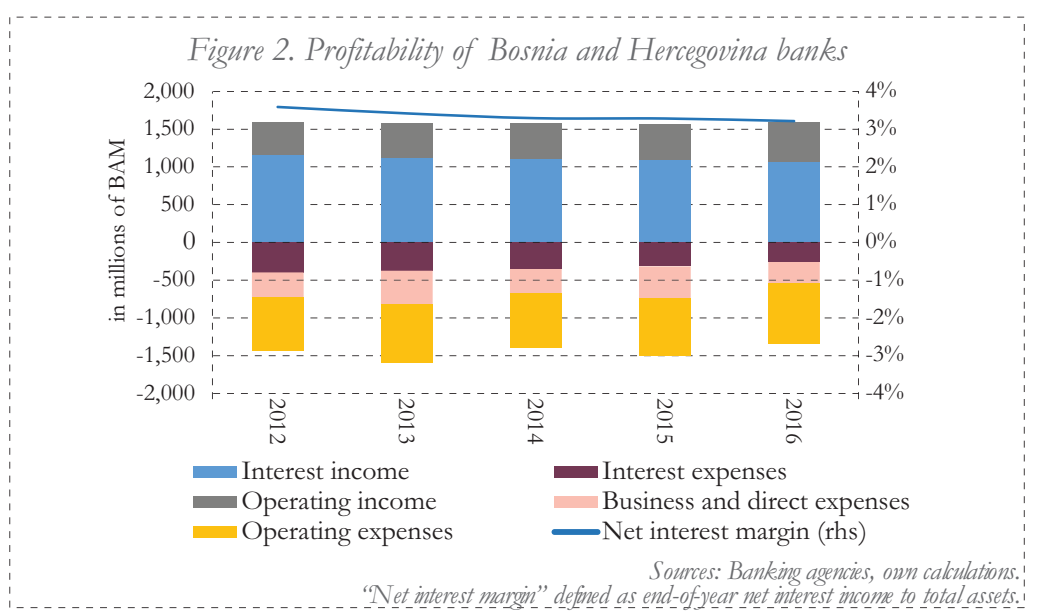


In 2015, the provisions were 524 million convertible marks, while in 2016 they amounted to 270 million. Very often we have claims by the media that the banking sector is profitable, despite relatively low interest rates and low credit growth. But one must have in mind what drives the profitability of commercial banks in Bosnia and Herzegovina, in 2016, the higher profits were driven by lower provisions.

About the NPLs issue, the ratio at the end of 2016 was 11.8 percent. This figure is very good compared to the rest of the region. However, I must emphasize that such a comfortable ratio has been reached after a long restructuring period, as much as the legal framework allowed, since we do not have a law regulating the transfer of NPLs and impaired assets to special purpose vehicles. There are persisting uncertainties concerning the tax treatment of such transfers and the disposal of impaired loans that the tax authorities have not clarified yet. That is one of the most important reasons the NPL ratio in Bosnia and Herzegovina is still relatively high, despite that the banking license of some entities has been revoked, so that their impaired assets do not count any longer as NPLs, and the non-performing assets of some of the remaining banks have been written off.

In terms of what is happening with interest rates (see Figure 3), let us compare the interest rates in Bosnia with those in the EU, as published on the ECB website.

Figure 3. Interest rates on loans to non-financial companies

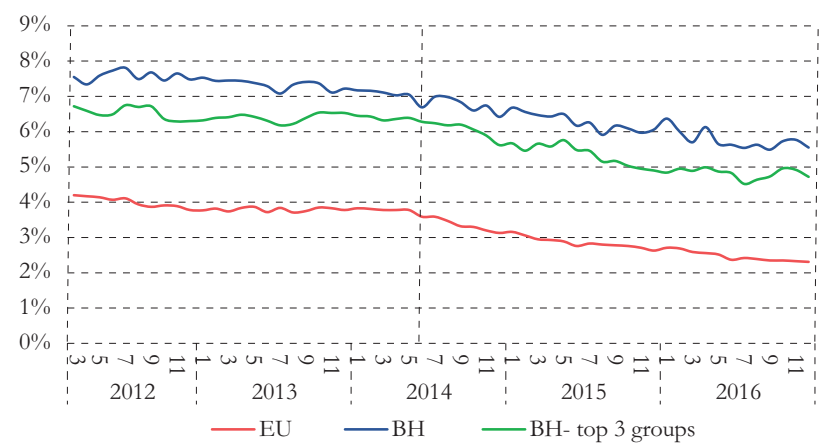

Sources: $C B B H, E C B$, own calculations. Series: Firms, loans up to and including 1 million EUR, up to 1 year, 3 months moving average. 
The chart shows moving averages of interest rates in EU and Bosnia for loans to firms for an amount up to EUR 1 milion and with a maturity non exceeding one year. One can see that they are pretty much moving in the same direction as interest rates in the EU and that there is a direct pass-through of changes in the EU interest rates to interest rates in Bosnia and Herzegovina for both large banking groups - the top three in terms of assets represented in the chart by a dashed line - and the banking system as a whole.

However, if one looks at the interest rates on loans to households (see Figure 4), the weighted average interest rates charged by the top three groups, which are coming from the EU, in Bosnia are rather different from both the EU and overall Bosnian average.

Figure 4. Interest rates on loans to households

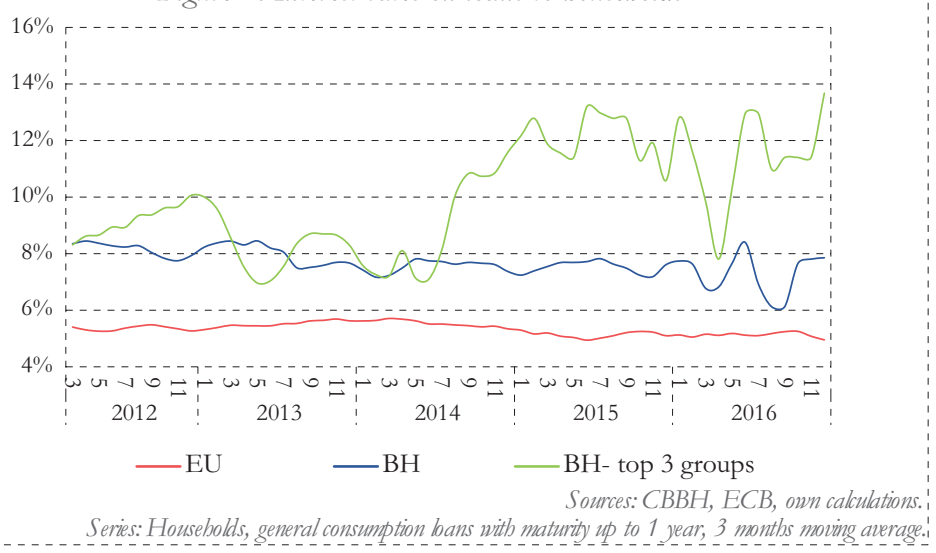

As of 2014, the interest rates have been increasing. In my view, this increase is quite interesting. If the average interest rates for the banking system as a whole are fairly unchanged, and the top three groups' rates are increasing, it must be the smaller banks charging much less, thus affecting the average interest rates in Bosnia and Herzegovina.

Therefore, another financial stability issue might be: which banks are driving the current credit growth? 


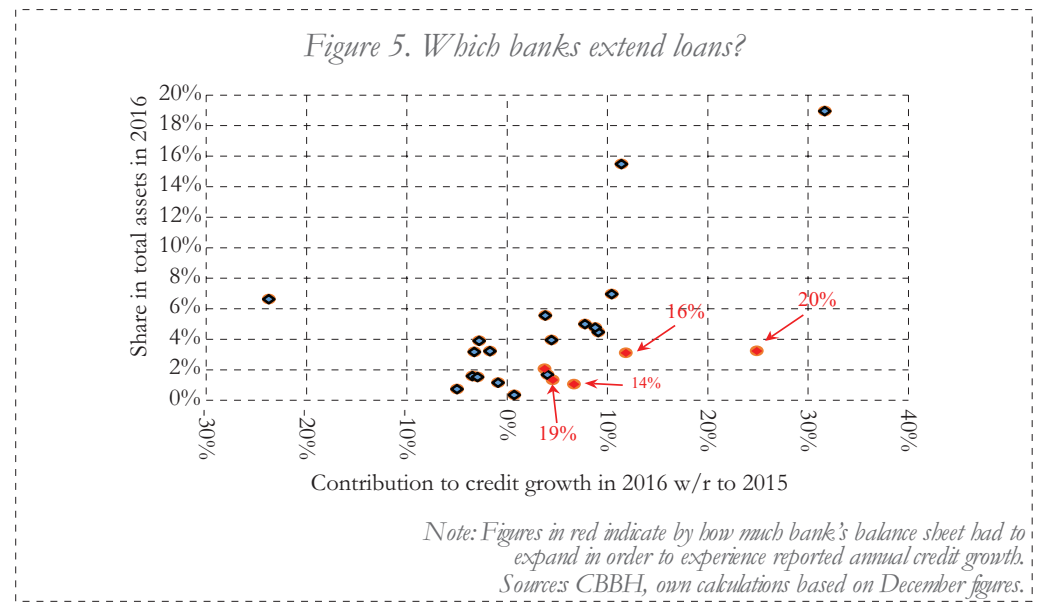

The horizontal axis represents the contribution to total credit growth in 2016, with respect to 2015, of each commercial bank in Bosnia and Herzegovina. The vertical axis shows the share of individual bank in total assets in 2016. Clearly, there might be vulnerability forming. A single bank, the one in the far top right-hand corner, has accounted for one third of credit growth of the banking sector in one year. Another serious issue is the contribution of small banks, represented by red dots. Very small banks, those with a share in total assets of the banking sector below 3 percent, accounted for a quarter of credit growth in 2016 compared to 2015. A very small one, with the share of banking sector assets under 1 percent, accounted for about 10 percent of increase in stock of loans in 2016, compared to 2015.

The red figures show how much their balance sheets had to expand in order to experience this large credit growth. In short, there is a group of very small banks expanding rapidly. This is something, especially in the case of households, that we witnessed in 2008 when large players started getting rid of bad clients. Some small banks were picking them up, thereby enjoying rapid credit growth. These same banks experienced serious problems with the NPLs a few years later; some of them are still struggling. 
Figure 6. Interest rates on deposits of households

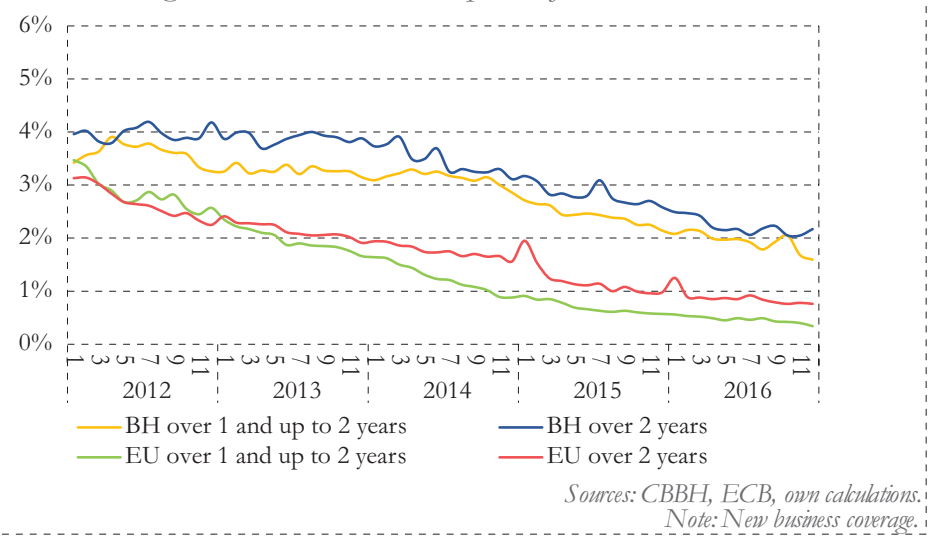

Regarding the interest rates on deposits to households (see Figure 6), one notices a peculiar thing.

The average interest rates on deposits of households over one and up to two years and over two years in Bosnia and Herzegovina are higher than those in EU. There are two things that we have to remember from earlier slides. I mentioned deleveraging of commercial banks in Bosnia and Herzegovina, which is the reason banks increasingly rely on deposits of domestic sectors. These are clearly savings deposits.

The vast majority of households' deposits are transaction accounts and sight deposits. Transaction accounts are high around payday, generally at the end of the month, which is also the reporting period.

Figure 7. Which households' deposits are growing?

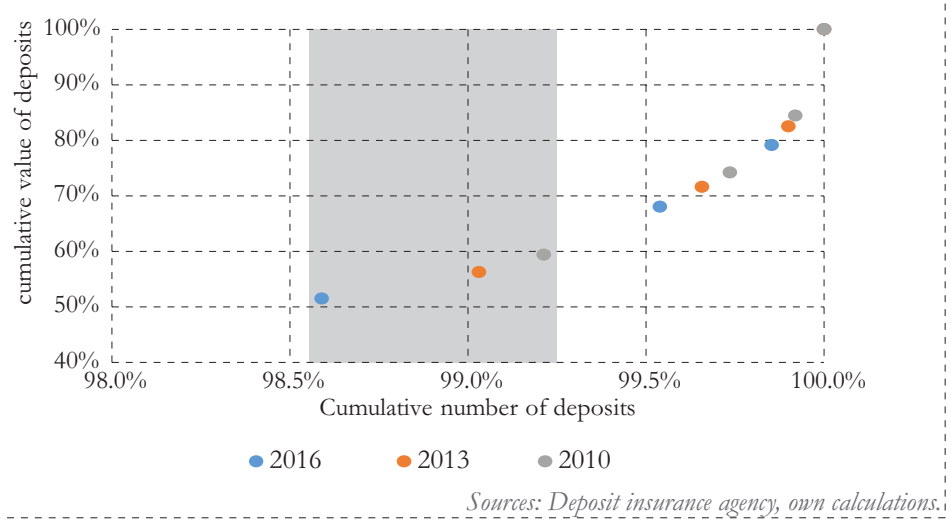


So, even if households deposits look fairly stable and high, it does not mean that there is a great lending potential. Finally, which households' deposits are growing?

In Figure 7, we have the cumulative number of deposits on the $\mathrm{x}$ axis and cumulative value of deposits on the y axis. The deposits up to a maximum of 50,000 convertible marks ( $\mathrm{KM}$ ) are all insured by the Deposit Insurance Agency (DIA). In Bosnia, everybody is quite aware of the significance of the DIA, as some banks have recently had their licences revoked and the prompt reaction of the DIA was very important in maintaining the perception of security of banks' deposits, thereby preventing deposit outflows elsewhere. The chart shows that over 98.5 percent of the total number of deposits are those up to 50,000 KM. The vast majority are, actually, up to 30,000 $\mathrm{KM}$. The cumulative value of deposits in this group was about 50 percent, which represents a 10 percentage point decrease with respect to 2010. Now, look at large individual deposits. Less than 0.15 percent of total number of deposits is over 20 percent of total value of deposits. From the chart it is evident that the number of large deposits is increasing over time.

Therefore, this perception of the overall households' deposits growth does not mean that the average person saves more. There is a possibility that "cherry-picked clients" of commercial banks, who have accounts with the same banking group abroad as well, got more favorable interest rates for saving in Bosnia and Herzegovina. By transferring their personal, or their company, deposits from the headquarters, for example, in Austria, to personal bank accounts in Bosnia and Herzegovina, household deposits in Bosnia grow, while banking groups themselves would reduce intragroup exposure to Bosnia and Herzegovina - assuming that the extra domestic deposits replace intra-group lending.

To conclude, if the credit growth is as sluggish as it is right now, relying on the activity of a handful of very small banks, and if domestic deposits, as they are, become the main sources of financing, there is a concern that we are possibly moving toward an environment in which long-term investments get increasingly financed via shortterm loans. This is similar to the environment already experienced in Bosnia in the early 2000s. This leads to similar maturity mismatch and liquidity risk problems as we have experienced in the past. 


\section{FINANCIAL STABILITY UNDER UNILATERAL EUROIZATION: THE CASE OF KOSOVO}

Central Bank of the Republic of Kosovo, Advisor to the Governor

I will speak on the financial stability experience of Kosovo. Like Montenegro, we have also adopted the euro unilaterally. This makes a difference compared to other countries with unofficial, partial euroization. So, I will try to make a distinction between a central bank that has monetary policy and a central bank that does not have monetary policy, and focus on the extent to which this is relevant for financial stability purposes.

Coming from a central bank without monetary policy, it is not very easy to speak on monetary policy issues in front of people, who conduct the monetary policy in their central banks. Nonetheless, I will try to make some points summarized in Figure 1.

Figure 1. Monetary policy and financial stability

- Central banks may pursue their financial stability objective through two policy tools:

- Monetary policy, mainly via short-term interest rates on loans to banks

- Macroprudential policy

- The use of monetary policy for financial stability purposes has increased after the crisis.

-Some Central Banks have incorporated financial stability in their main objectives.

The views expressed in this article are those of the author and do not necessarily represent the views of the Central Bank of the Republic of Kosovo. 
Financial stability has become an important objective for almost every central bank. Central banks can pursue financial stability objectives mainly through two policy tools, including the monetary policy, which acts primarily via short-term interest rates on loans to banks, and more recently the macro-prudential policies. Recently, especially after the crisis, monetary policy has been increasingly used for financial stability purposes in many countries, and several central banks have already incorporated financial stability into their key objectives. However, key questions remain on whether a central bank can pursue financial stability objectives through monetary policy instruments and on the modalities to do so. What about central banks (for example, in the case of Kosovo) that do not have monetary policy? Can they still be effective in maintaining stable financial sectors? In the following part of my presentation, I will try to address these questions and contextualize them in the case of Kosovo.

The most common way for the monetary policy to pursue financial stability objectives is to engage in countercyclical policies or to "lean against the wind" by setting policy interest rates that are higher than what would be required for stabilizing inflation or output. This is also in line with the previous discussions, in which many argued that low interest rates can induce higher risk taking. In this regard, setting high interest rates would, on the one hand, discourage households and firms from borrowing and, on the other hand, may encourage banks to reduce their leverage ratios. Therefore, higher interest rates are expected to reduce the level of risk.

Also, the central banks that have monetary policy can use monetary policy instruments to increase the money supply and exercise the lender of last resort (LOLR) function by injecting liquidity into distressed banks.

Therefore, monetary policy instruments can be used to enhance or restore the financial stability. However, are they always effective in the pursuit of financial stability? Let us elaborate on some issues that suggest that monetary policy may not necessarily be effective as a tool to safeguard the financial stability. By setting higher interest rates, the central bank can discourage borrowing and 
reduce leverage, but at the same time it can reduce the aggregate demand and weaken the general economic activity, hence possibly decreasing the capacity of borrowers to repay their loans. Also, when liabilities have variable rates and short-term maturities, the increase of interest rates may increase debt servicing costs. In this way, the policies that increase the interest rate may further weaken the capacity of borrowers to repay their loans. This shows that monetary policy, though an important policy tool, has its own limitations and may not serve as a readily available tool to pursue the financial stability objectives.

In addition, despite the enhanced role of financial stability in central banks' mandates, the primary objective of most of the central banks remains price and output stability. In this regard, central banks may face trade-offs between pursuing financial stability objectives and their traditional objectives, which are price stability and output or employment stability. Therefore, engaging in countercyclical behavior, that is, leaning against the wind by increasing the interest rate, involves paying a short-term cost by having a negative impact on output or employment in exchange for a medium-term benefit in the form of lower expected costs from the financial crisis (IMF Staff Report, 2015). This trade-off between financial stability and price stability objectives may undermine central bank credibility, because the short-term costs in terms of lower output or employment are very easily observable by the public, whereas the medium-term benefits in terms of lower expected costs from the financial crisis may never occur and are not easily observable by the public. In other words, leaning against the wind entails bearing a certain cost, which is widely felt by economic agents, in exchange for a potential benefit that is not certain to appear and, even if it does, it is not easy for it to be noticed by the wider public. Thus, leaning against the wind may damage the credibility of the central bank, and this loss of credibility may undermine the effectiveness of monetary policy and may even de-anchor the inflation expectations.

Another issue regarding the effectiveness of monetary policy in pursuing financial stability objectives is related to the effectiveness of the monetary policy transmission mechanism, especially in countries that have a high scale of euroization. 
Under such circumstances, even if you have discretion over the monetary policy, you will not necessarily be able to affect the stability of the financial sector. Furthermore, even though the central bank's interest rate is important in driving the interest rates charged by banks, we know that there are also other interest rates that may be important and relevant in the market, meaning that the transmission of the central bank interest rate to the commercial bank interest rate may not be very strong (Billi and Vredin, 2014).

Another channel through which central banks can have an impact on the financial stability is the LOLR function. The countries that have their own currency can be more effective in exercising the LOLR function because they can extend unlimited amounts of funds in their own currency, in case of need. However, in countries that have a large share of foreign deposits, the central bank may not be very effective in using the LOLR function, because its ability to use this function will depend on the amount of the international reserves available or the ability to increase them by borrowing. Even if the central bank can use this function, the active use of it may induce moral hazard by reducing the incentives of banks to manage their liquidity in a prudent manner, to act responsibly in accordance with their risk-bearing capabilities and, in case of crisis, to recapitalize and restructure.

So, having looked at the ways in which monetary policy can be used to pursue financial stability objectives and its limitations to do so, let's now turn to the case of Kosovo and see how it dealt with financial stability under the conditions of unilateral euroization, which means no or very limited monetary policy tools are available. Kosovo's experience is summarized in Figure 2. 
Figure 2. Unilateral euroization and financial stability in Kosovo (1)

- The use of euro has strengthened macroeconomic stability, leading to low and stable inflation.

- Exchange rate risk has been minimized.

- Over 95 percent of the balance sheet of the banking sector denominated in euro

- The confidence of banks in the economy and the confidence of depositors in the banks has strengthened.

The use of euro in Kosovo has strengthened the macroeconomic stability leading to low and stable inflation, which has been in line with the inflation rates in the euro area - the region with which we have the strongest trading ties. The exchange rate risk has been minimized after the euroization. Over 95 percent of the balance sheet of the banking sector is denominated in euro. This has led to a stronger confidence of banks in the economy and also to a stronger confidence of depositors toward the banks. This is one of the reasons why the deposits on the banking system of Kosovo have been very stable. Even during the crisis time, the confidence of the depositors has never been dented.

Having the financial stability as the main objective of the Central Bank of the Republic of Kosovo (CBK) and not having any "headaches" with the exchange rate and price stability issues, the CBK has been able to focus on the development of functions that are more relevant to the financial stability. Even though the CBK is a relatively new central bank, it has been quite successful in developing these functions, including the bank supervision, regulation, licensing, and financial stability units.

I mentioned earlier the LOLR function. This is one of the limitations to the CBK brought by the unilateral euroization, but we have managed to offset it to some extent by introducing an emergency liquidity assistance scheme, which is jointly funded by the central bank capital and the Government of Kosovo. We have a fund intended to be 
used for injecting liquidity into solvent banks, which are experiencing short-term liquidity problems. In addition, 90 percent of the banking sector of Kosovo is foreign owned. Out of 10 banks, eight are foreign owned banks, which compose 90 percent of assets, which implies that, in case there are additional needs for liquidity, we can expect a flow from the parent banks. Another argument for this is that the foreign banks that operate in Kosovo are very important in terms of size for Kosovo, but are very small relative to their own groups. So, we expect that any liquidity need of foreign banks in Kosovo would be easily fulfilled by their parent banks, because it would be a very small amount compared to the size of the parent bank.

The limited space of the CBK to act through the LOLR function has led to more conservative behavior by the central bank in terms of banks' supervision, and also to a more disciplined behavior by the banks themselves. Banks in Kosovo are very much aware that they cannot easily knock on the door of the central bank to get help. This has encouraged a very disciplined behavior from a banking system that has remained sound, as it could not rely on the central bank liquidity back stop.

In terms of recapitalization needs, should a bank need such intervention, it is rather an issue for the government than for the central bank. The lack of monetary policy instruments may not be highly relevant in this context. This issue is mainly related to the solvency of the government, rather than to the capacity of the central bank to support the commercial banks.

The CBK has developed recently a macro-prudential framework, which, to some extent, is expected to fill some of the potential gaps created due to the lack of monetary policy. We have developed this framework based on the guidelines of the European Systemic Risk Board (ESRB) and we have also established a macro-prudential Advisory Committee within the central bank, composed of the heads of the relevant departments within the central bank. So far, the role of this committee has been mainly to analyze financial stability developments and the identification of the build up of any potential risk, while no macro-prudential measures have been deemed necessary to be taken so far. The macro-prudential policy 
has the advantage of being capable to target the risks closer to their source, in contrast with the monetary policy, which may be less able to deal with specific risks occurring in the banking sector.

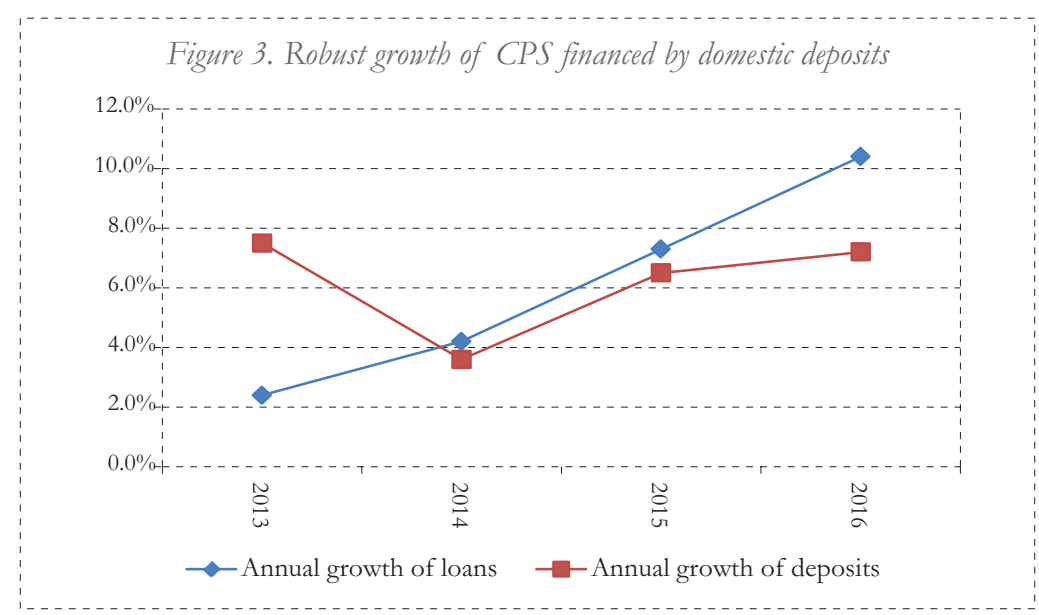

Given all this, now let's see briefly how Kosovo is performing in terms of financial stability. We have had a robust growth of credit to the private sector as evidenced by Figure 3, which has been mostly financed by domestically-collected deposits. In fact, it is also a characteristic of the banking sector in Kosovo that we have a small degree of exposure toward the external sector, both in terms of loans and deposits. Domestically-collected deposits amount to around 80 percent of total liabilities, which means that our banks have not relied very much on the developments in the external financial markets.

Figure 4. Loans-to-GDP ratio increases, still space to converge to region's average

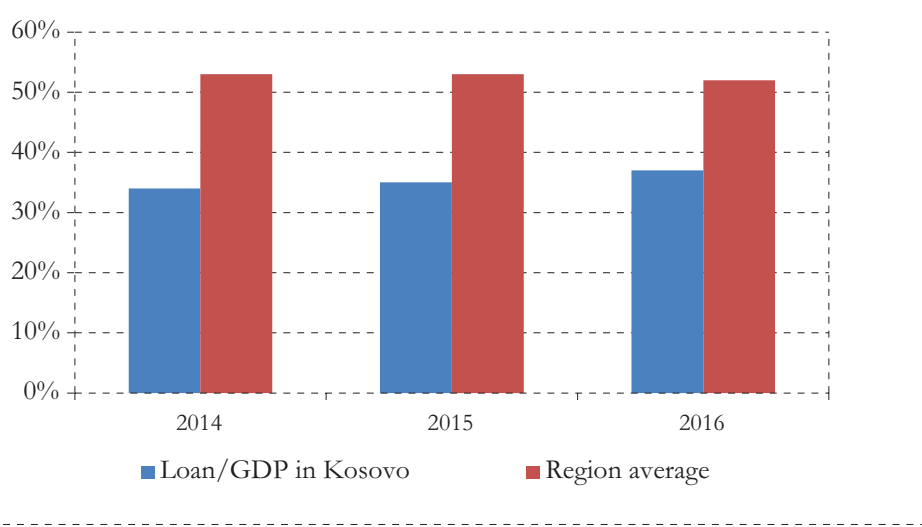


Despite the quite sustainable increase of lending, still the loan-toGDP ratio remains below the average of the region, as exhibited in Figure 4. This means that there is still space to deepen financial intermediation, but here we must acknowledge the fact that the Kosovo banking sector started to operate later than the rest of the region. The sustainable lending activity growth has enabled a gradual convergence toward the average financial intermediation ratio of the rest of the region.

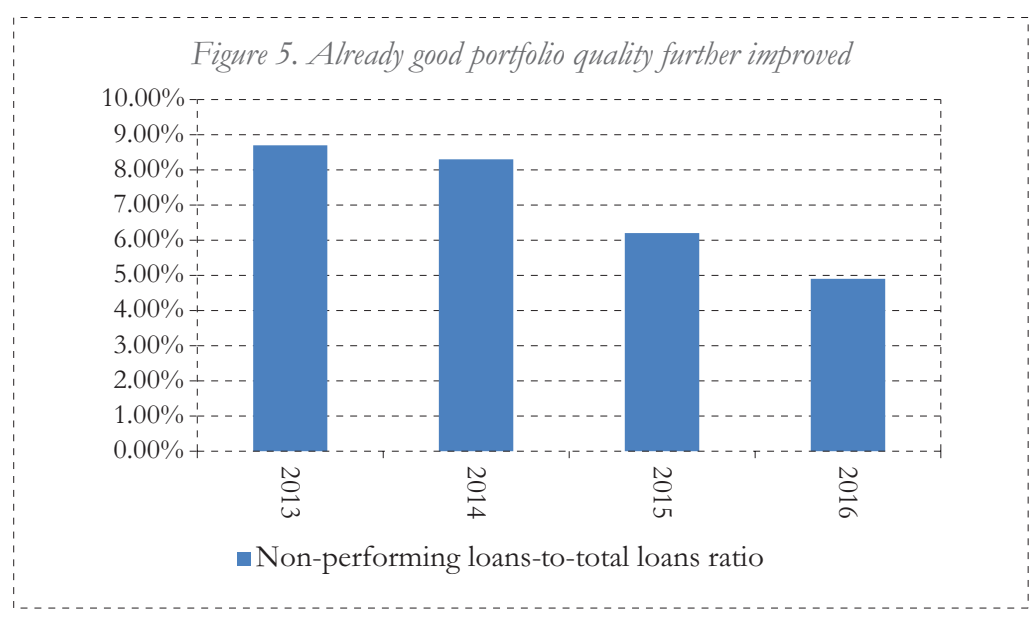

The already good portfolio quality has further improved during recent years, as exhibited by Figure 5. At the end of 2016, the nonperforming loans (NPL) ratio was 4.9 percent and it has further declined in March 2017 to 4.5 percent. As we can see, the NPL ratio has remained very low all the time and it has not experienced any recent sharp spike, as observed in some of our neighboring countries. It peaked in 2013, when it reached 8.7 percent, but it has never reached two-digit figures. The reasons for this are related quite a lot to that conservative behavior of the banking sector that I mentioned earlier, and also to the fact that we started a new banking system and we did not inherit problems that the other countries did with state-owned banks and other similar problems. The first bank to operate in Kosovo was a foreign-owned bank and then the following banks were also foreign. Although two domestically-owned banks eventually started operating, they mostly hired the personnel from the foreign-owned banks, which means that we started the banking 
sector by applying modern banking practices, and this is one of the reasons that the quality of loan portfolio did not experience any deterioration.

Figure 6. Judicial reform and base effect underlying loan quality improvement

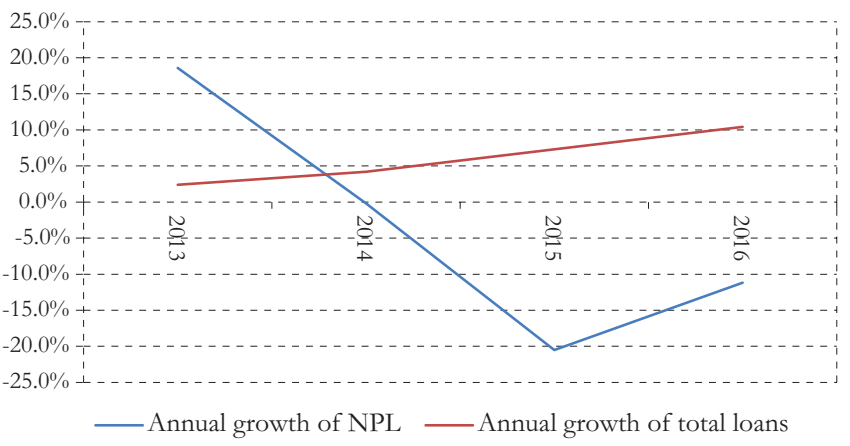

The dynamics of the amount of total loans and the amount of NPL as evidenced in Figure 6 show that while total loans have maintained an upward trend, the amount of nonperforming loans has declined during recent years. The recent decline in the amount of nonperforming loans is related also to the legal reforms that have been undertaken in Kosovo. One of the most important problems in Kosovo was related to the efficiency of courts in enforcing contracts, but now we have amended the enforcement procedure law, which makes it very easy for banks to enforce contracts. Now the enforcement authorities can very easily freeze the banking accounts of bad debtors and transfer the amounts to the relevant parties. We have also reduced the number of auctions required to execute the collateral. Another important development is the functionalization of the private enforcement agents, which are helping a lot the courts in enforcing the contracts. These developments enable banks to offload some bad debts held on their balance sheet for some time and also impact the future attitude of borrowers in terms of abiding by the terms of their loan contracts. These developments have contributed to containing and reducing credit risk. The lower credit risk has contributed to a substantial decline of loan interest rates, which, until recently, were considered still excessively high. 
Nonperforming loans remain very well provisioned with loan-loss provisions. As we can see from Figure 7, this ratio never dropped below 100 percent, which means that banks are being very careful in maintaining the loan-loss provisions.

Figure 7. NPLs well covered with provisions

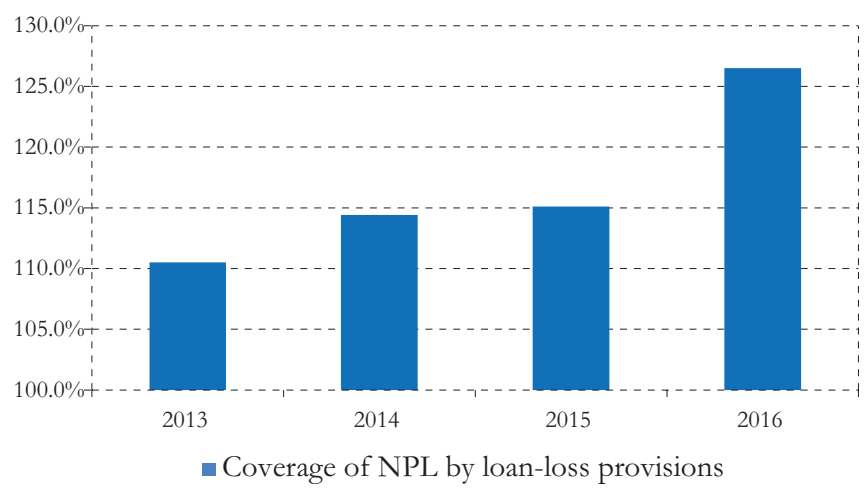

Figure 8. Banking sector well capitalized, CAR well above regulatory requirement Capital Adequacy Ratio

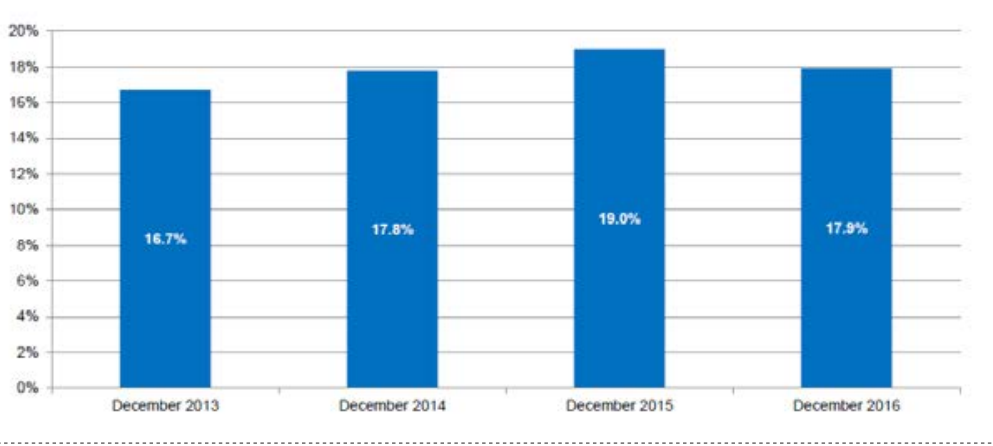

As evidenced by Figure 8, the capitalization ratio of the banking system remains satisfactory, well above the regulatory requirement of 12 percent. 
Figure 9. Loan-to-deposit ratio low, space for lending expansion

\section{Loan-to-deposit ratio}

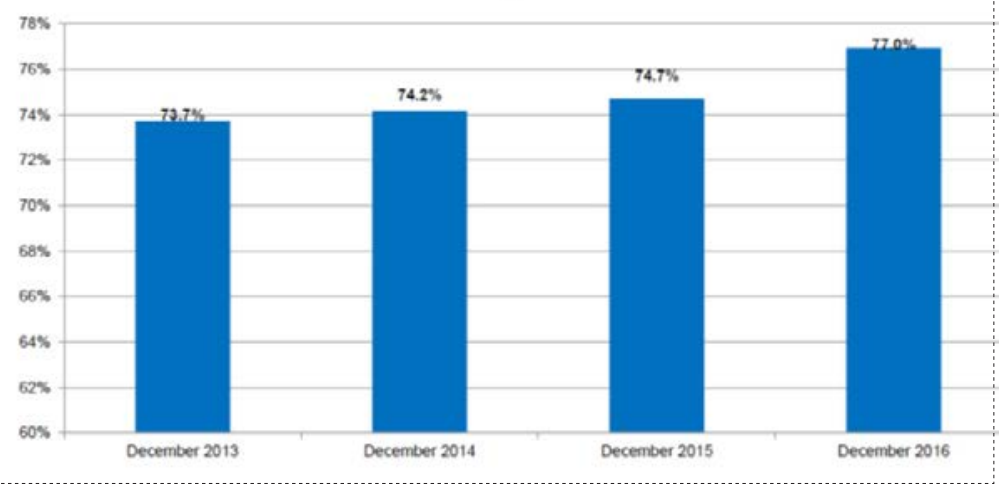

The loan-to-deposit ratio, as evidenced by Figure 9, remains below 80 percent, suggesting that still there is space for lending expansion without causing liquidity concerns.

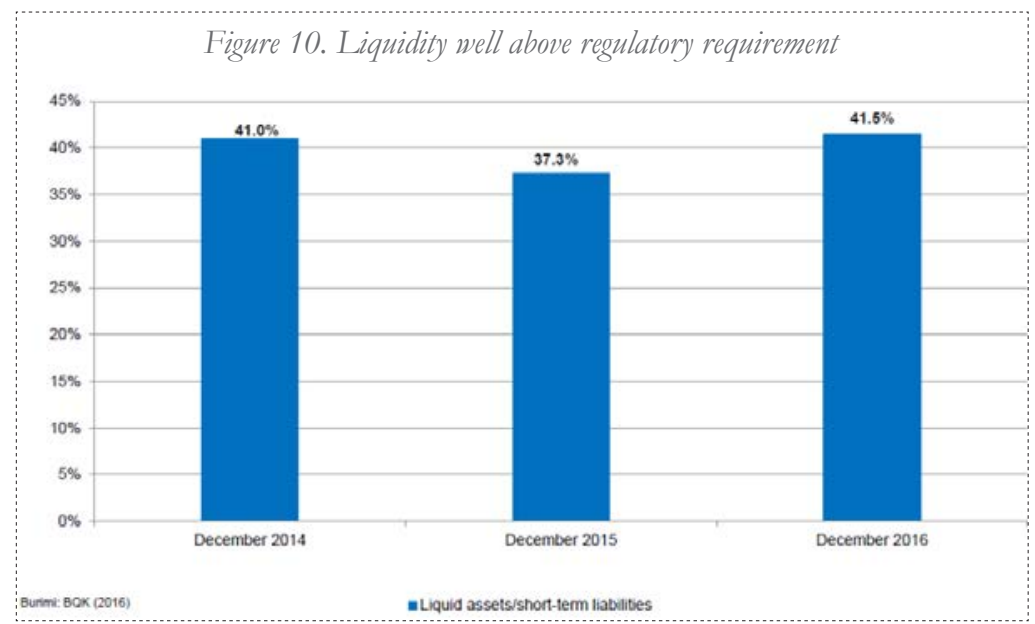

Also, the liquidity position, shown in Figure 10, remains strong, with liquid assets to short-term liability standing above 40 percent. 


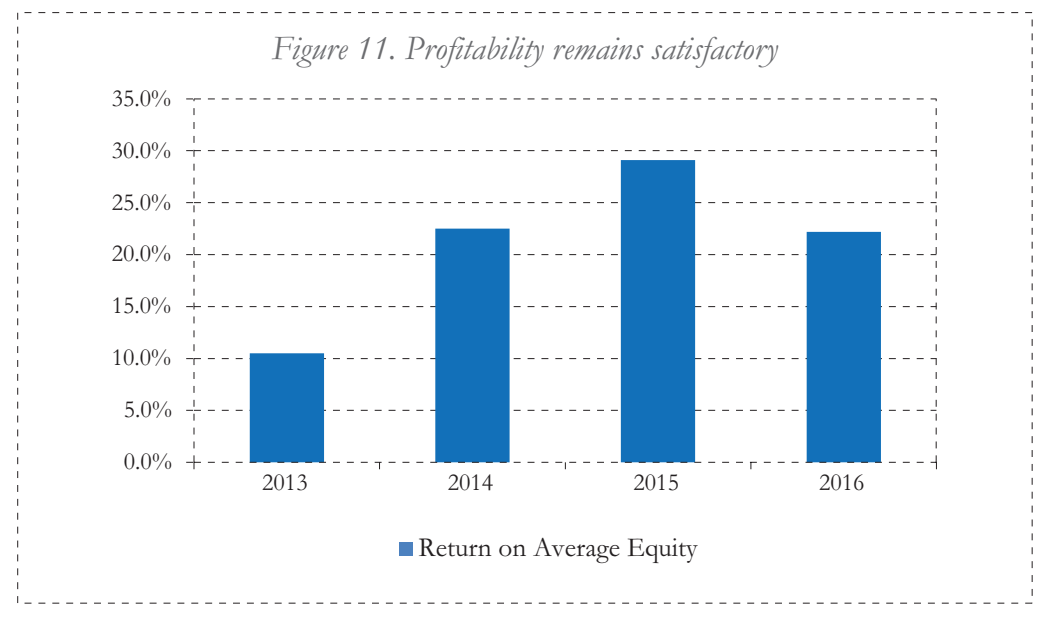

The degree of profitability remains satisfactory, with the profitability rates standing at higher levels compared to the banking sectors of the other countries in the region. This was due to the high interest rates on loans, but is also to the good quality of the loan portfolio. We can see in Figure 11 that the profitability levels remain high, despite the substantial narrowing of the interest rate spread from 8.5 percent in 2013 to 6 percent in 2016 (see Figure 12).

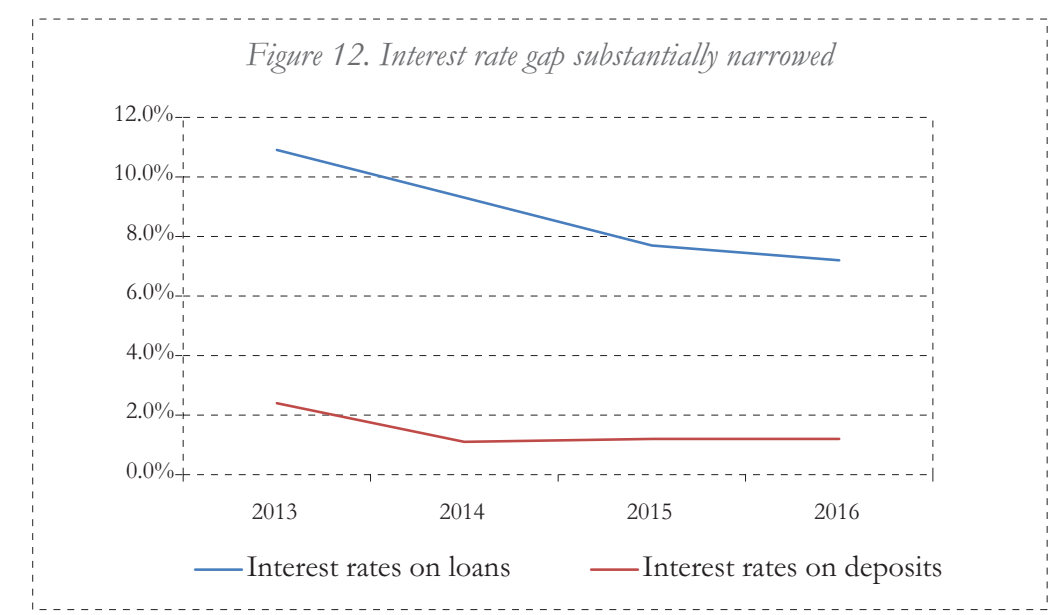

We can see from Figure 12 that banks have maintained the deposits, interest rates at a low level during the past years, but have continuously reduced the interest rates on loans. I have presented 
data from 2013, but just in 2011 or 2012 the interest rates averaged 14 percent, and we can see that within a short period of time, they have halved average interest rates on loans. This was one of the main obstacles for access to finance, and we can see that banks are easing the access to finance. In addition to the judicial reform, other important factors that have affected the decline of loan interest rates include the steadily low deposit interest rates and increased banking sector competition. Even though we did not have a rapid increase in the number of banks, we can see that banks have started to compete more, by expanding in volume after the decline of interest rates. Currently, the interest rate spread in the banking sector of Kosovo stands at the average level of the region.

Let me summarize by drawing some conclusions from this presentation. Monetary policy appears to be an important tool to pursue financial stability, but it may not be necessarily effective. Therefore, monetary policy discretion in unilaterally euroized economies is not necessarily "missed" with regard to the financial stability, meaning that financial stability can be maintained even without full autonomy over the monetary policy. Unilateral euroization in Kosovo has reduced the financial risks and has enabled a greater focus on financial stability issues. In addition, as we can see from the recent decline of the interest rates in Kosovo and the decline of NPLs, the enhancement of the financial intermediation efficiency and the reduction of banking sector risks in unilateral euroized economies are rather pursued through structural reforms, which may guarantee longer-term and healthier outcomes for the stability of the financial system and the economy in general. 
This page intentionally left blank 


\section{ECB NON-STANDARD MONETARY POLICY MEASURES AND FINANCIAL STABILITY IN WESTERN BALKAN ECONOMIES WITH EMPHASIS ON THE MONTENEGRO CASE}

Milena Vučinić
Central Bank of Montenegro, Department for Financial Stability, Research
and Statistics

\section{INTRODUCTION}

It is my pleasure to be here and to benefit from the exchange of opinions and experiences. As you may know, pursuant to the Central Bank of Montenegro Law, the Central Bank of Montenegro (CBCG) sets out fostering and maintaining the financial system stability and a sound banking system and safe and efficient payment systems as its main objectives. The financial system in Montenegro is bank-centric. In a dollarized (euroized) and bank-centric systems, such as the one in Montenegro, a stable financial system is a condition for creating and preserving the stability of the economic system.

\section{THE CONTEXT}

In response to the global financial crisis and in response to a number of economic and financial events, the ECB, similar to other central banks of major countries, significantly reduced its key interest rates and implemented several nonstandard monetary policy measures, in order to address various risks, including low inflation and dislocation in the liquidity of certain asset markets in the euro area.

South-east European (SEE) countries are small, open economies with very close trading relationships with EU countries. These same countries with which there are close trading ties are a source of capital, foreign direct investments and portfolio investments. Banks in South-east European countries are to a large extent controlled by banking groups headquartered in the euro area. This resulted in sizeable financial flows, mostly within the same banking group, particularly prior to the global crisis. 
The very high degree of economic and financial integration between the euro area and SEE countries creates potential monetary policy spillover effects.

Montenegro is a small country with a population of only 620, 000 people. It is a small and open euroized economy, highly exposed to external effects.

According to the Ministry of Finance, the real GDP growth rate for 2016, based on quarterly estimations, has been 2.5 percent and the projections for the next two years, 2017 and 2018, are 3.2 percent and 4.4 percent, respectively. During 2016, annual inflation rates were mostly negative, but the December Consumer Price Index (CPI) was positive at around 1 percent. The CPI rose in March 2017 to 2.7 percent on an annual basis.

\section{RISKS}

The main risks in Montenegro are coming from three sides: fiscal side, financial sector, and real sector. Of the three, the biggest is the fiscal risk, due to high public debt. At the end of December 2016, the public debt of Montenegro amounted to EUR 2,546.1 million, or 67.5 percent of GDP, and was above the Maastricht criterion of a debt-to-GDP ratio of 60 percent. Also, in the period 2019-2021, more than 1 billion euro eurobonds are due to be repaid, while from 2021 onward is planned the repayment over a 14-year period of a loan granted for the construction of the highway Bar-Boljare.

In order to reduce the high level of public debt and reduce the budget deficit, the government has launched a fiscal consolidation plan. This nevertheless, the budget deficit is still high. At the end of 2016, the budget deficit was still 3.4 percent of the GDP.

In the Montenegrin financial sector, the banking sector has a dominant market share of over 90 percent of total financial sector assets. Therefore, the biggest financial risk is credit risk that comes from the banking system. Credit risk is decreasing, but it is still 
deemed to represent a significant potential risk for the banking system.

In terms of other banking sector vulnerabilities, non-performing loans (NPL) were quite high after the crisis. As a transition economy, we had a boom-bust period, and, after that, in 2011, NPLs amounted to over 24 percent of total loans. Today NPLs have been significantly decreased, to 10.2 percent.

The third risk is coming from the real sector. The real sector was illiquid after the crisis. Nowadays banks are highly liquid while the real sector continues to remain illiquid. After the crisis, banks have tightened lending standards and have become more selective in the loans approval process to the real sector.

\section{CENTRAL BANK OF MONTENEGRO OBJECTIVES AND INSTRUMENTS}

CBCG is quite a peculiar central bank in terms of objectives and instruments. It operates within a euroized monetary policy regime, in which the monetary policy objectives and instruments are also peculiar to such a regime. Similarly to the Central Bank of Kosovo, the main policy objective of CBCG is to preserve the financial stability. Financial stability in Montenegro is necessary not only to promote internal stability, but also to attract the inflow of FDIs and the development of small and medium-sized enterprises necessary for the economic convergence process with the EU.

Efficient supervision and prudential policy for ensuring and preserving a sound and safe banking sector are at the disposal of CBCG to achieve its primary objective. In light of the weight banks have within the overall financial system, the stability of the banking system is a fundamental determinant of the stability of the entire financial system. Banks are also the primary source of funding for all sectors of the economy. 
The banking system in Montenegro consists of 15 banks, 9 of which have a majority stake controlled by foreign owners. Five banks are members of EU banking groups. Stronger competition is the result of new banks entering the domestic market. There has been a positive influence on interest rates from the entry of new banks into the system, contributing to a general downward trend on lending interest rates and narrower spreads between deposit and lending rates.

\section{ECB MONETARY POLICY SPILL-OVER TO WESTERN BALKAN CENTRAL BANKS}

All economies in the region are open economies with strong trade and financial linkages with the EU. Therefore, the accommodative monetary policy of the ECB is transmitted to the region.

Despite the heterogeneity of the monetary policy and the exchange rate regimes in the region, the policy rate reaction of the central banks has been mostly in line with the accommodative stance of the ECB.

The low interest rate environment in the euro area provided scope for lower interest rates in the region. The more accommodative monetary stance across the central banks in the region led to a relaxing of financial conditions for the private sector borrowing.

As a result of lower ECB rates, banks in Montenegro decreased lending interest rates both for corporates' and households' loans although they remain quite high when compared to euro area levels. Even though lending interest rates are still high compared to the European average, they have exhibited a downward trend. This is evidenced by Figure 1, which shows the weighted average effective lending interest rates (WAELIR) on total loans and for corporates and households. We can see that the WAELIR are decreasing. For example, there is a decrease of WAELIR on total loans from 8.47 percent in January 2016 to 7.42 percent at the end of February 2017. Still, these rates are quite high. 
Figure 1. Weighted average effective lending interest rates for period 31.01. 2016-28.02.2017.

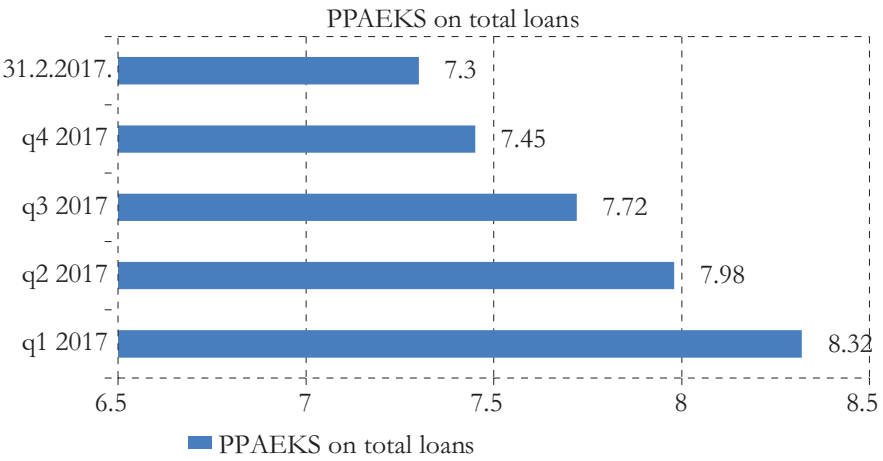

Source: Central Bank of Montenegro.

WAELIR on new businesses on a monthly basis are also on a downward trend, as evidenced by Figure 2. For example, in February 2017 the average effective lending interest rate on new loans was 6.88 percent, which has been one of the lowest in the last periods.

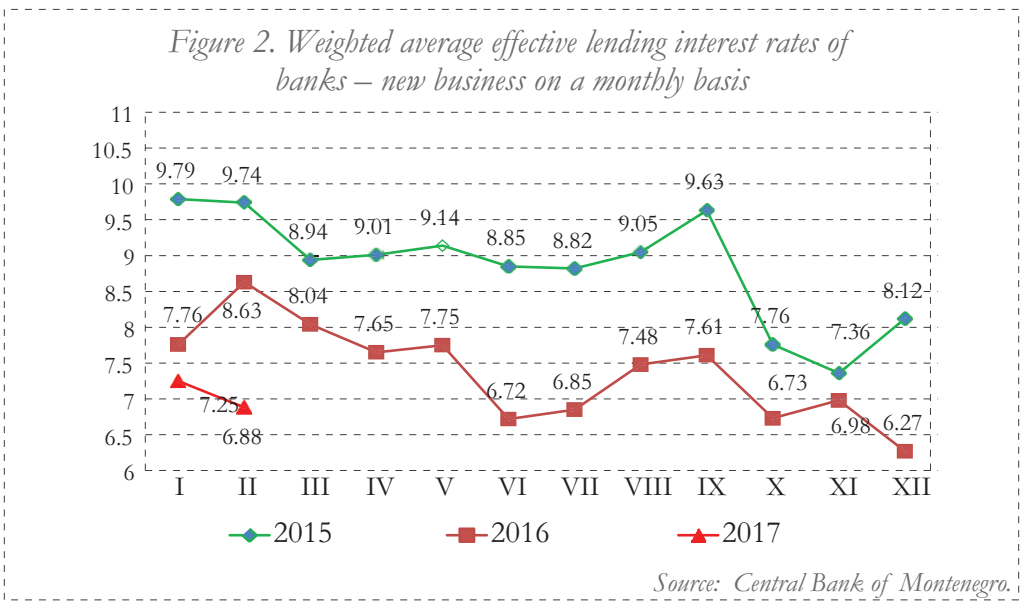

\section{FISCAL POLICY AND DEBT MANAGEMENT STRATEGY}

Due to the high public debt and budget deficit, the Government of Montenegro had to search for external financing sources. In 2016, it issued a eurobond. It was the sixth issuance since 2010, for a total 
issued amount of EUR 300 million for a five-year maturity at a rate of 5.75 percent. In November 2016, Montenegro issued domestic bonds for EUR 80.4 million, with a four-year maturity, at a fixed interest rate of 4 percent, for financing the budget deficit, capital budget, and public debt servicing and fiscal reserve provision.

The Government of Montenegro opted for what was called a growth strategy. There are pros and cons of this strategy: financial sources at lower rates, but increased public debt.

The growth strategy includes an increase in capital investments and the biggest infrastructure project: highway construction. It is actually the biggest capital investment project in the history of Montenegro.

\section{POLICY IMPLEMENTATION AT CBCG}

Although CBCG does not have an independent monetary policy, it does have monetary policy instruments it can use in the pursuit of its objective. They include: open market operations, credit operations, lender of last resort, and reserve requirements. Until now, CBCG has actively used only reserve requirements. The CBCG has used the reserve requirements on bank deposits in order to manage credit cycles and liquidity and, to some extent, to achieve macro-prudential goals. Namely, with these instruments, the central bank affects the banks' lending activity, and indirectly affects the further process of money multiplication (money supply) in the economy.

In the pre-crisis period, CBCG increased the reserve requirement's rates on bank deposits in order to limit excessive credit growth and limit the excessive leverage of borrowers in the economy. In the post-crisis period, it lowered the reserve requirement's rates to ease liquidity constraints and encourage further banks' lending.

In to the period 2006-2008, the CBCG objective was to rein in credit activity and try to strengthen the bank's resilience to potential risk of a credit boom. In that period, the bank adopted a conservative approach with its regulatory instruments. Banks' regulations, at that 
time, was stricter than the international ones, especially the prudential one. CBCG has used reserve requirements on bank deposits in order to manage credit cycles and liquidity and to some extent, to achieve macroprudential goals.

Recently - as of March 2017 - reserve requirements have instead been lowered, with the reserve requirement ratio lowered from 9.5 percent to 7.5 percent for demand deposits and time deposits with a maturity not exceeding one year, and from 8.5 percent to 6.5 percent for time deposits with a maturity exceeding one year.

In the current environment of low inflation and a zero interest rate, the effectiveness of monetary policy instruments has been challenged. The recent global financial crisis has posed new challenges for the monetary policy and demonstrated the need for a more comprehensive approach in the pursuit of objectives. In the absence of monetary policy, CBCG focuses on financial stability. CBCG is currently developing a macro prudential policy framework and instruments. Having the mandate for preserving financial stability, CBCG potentially has a mandate for macro-prudential policy, also.

\section{FINANCIAL STABILITY IN MONTENEGRO}

According to the last statement of the Financial Stability Council, the financial system in Montenegro is stable, systemic risk is moderate, with potential risks arising from the low liquidity of the real sector and its potential insolvency risks. These risks are also exerting pressure in the fiscal domain.

The Financial Stability Council was established in 2010. Its members are: the Governor of the Central Bank of Montenegro, the Minister of Finance, the Director of the Agency for the Supervision of Insurances, and the President of the Securities Commission. The Financial Stability Council was established with a view to monitoring, identifying, preventing, and mitigating potential systemic risks in the financial system of Montenegro as a whole, in order to ensure the maintenance of financial system stability and avoid episodes that may lead to widespread financial distress. 
The following figures show recent data about financial stability. They will be published in the financial stability report. The aggregate index of financial stability (AIFS) is a derived index. The AIFS is shown in Figure 3. The AIFS is used to assess the financial stability situation calculating four subindexes, which refer to: external sector (payment system), government (public finance), real sector, and financial sector. The AIFS is used to assess the systemic instabillity trends. At the end of 2016, the AIFS was higher compared to the end of 2015.

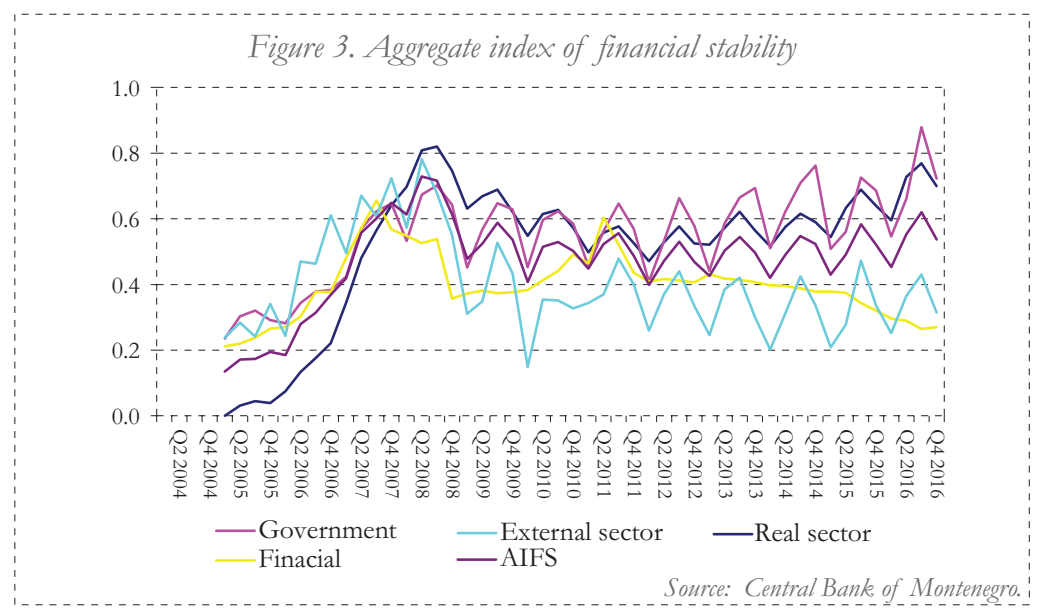

Below, in Figure 4, there is a financial stability diagram. It shows financial stability developments from 2014 to 2016. Risks emanating from fiscal and external sectors are the predominant ones. Other risks are either stable or have only a minor influence on the overall financial stability.

As for the external sector, risks are very visible and have exhibited a significant increase compared to 2014 , primarily due to a widening trade deficit as a result of a drop in export.

Risks referring to non-financial sector have slightly increased compared to 2015, but are almost stable. Fiscal sector risks increased a half point (0.5) due to the increase of public debt, their financing conditions, and the announcement of a higher budget deficit as a result of the investments in infrastructure. 
Figure 4. Financial Stability Diagram

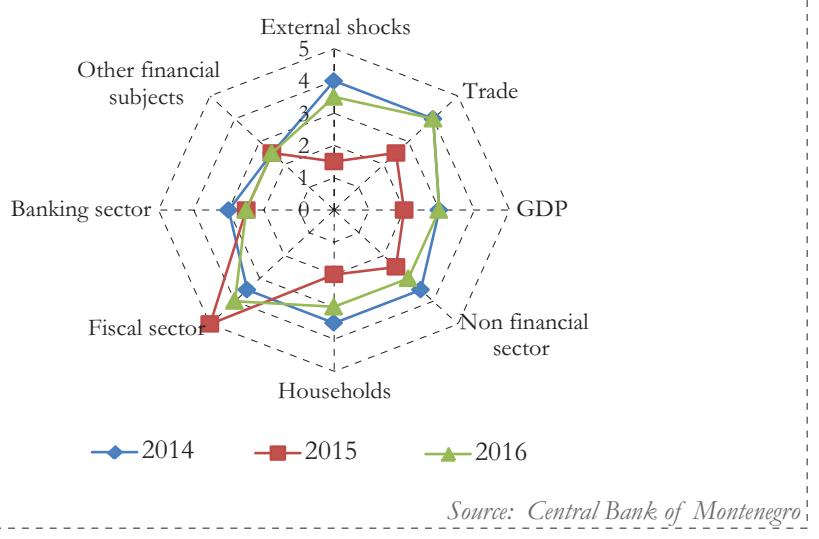

The banking sector risks are stable compared to 2015. 
This page intentionally left blank 


\section{THIRD SESSION: NEGATIVE EURO AREA INTEREST RATES AND RESERVE MANAGEMENT}

Moderator: Elisabeta Gjoni Bank of Albania, First Deputy Governor 
This page intentionally left blank 


\section{INTRODUCTORY REMARKS: PANEL ON "NEGATIVE EURO AREA INTEREST RATES AND RESERVE MANAGEMENT", \\ Elisabeta Gjoni Bank of Albania, First Deputy Governor}

After a very interesting morning dedicated to recent financial stability challenges in a negative euro area interest rate environment, I am introducing a panel on reserve management challenges in a context of negative euro area interest rates.

Financial stability and reserve management are two topics that are intertwined together for the reasons we have discussed this morning. Due to widespread euroization, countries in the region are exposed to exchange rate shocks that may impair the debt servicing capabilities of unhedged borrowers, raise financial stability risks, and may ultimately impair the effectiveness of monetary policy transmission. Therefore, key policy questions are: what the appropriate level of FX reserves should be and how they should be invested to make sure they are readily available when needed to fulfill the different purposes for which FX reserves are held.

Adequate levels of FX reserves are needed to mitigate financial stability risks, to support the exchange rate policy, to meet government foreign currency needs.

This means, however, that FX reserves may represent a sizeable part of the central bank's balance sheet. This exposes the central bank's balance sheet to costs due to the differential between the rate of return of FX assets and the return on alternative assets denominated in the domestic currency. Such costs are exacerbated by the negative interest rate environment, which has depressed the rate of return on FX assets. 
Central banks are not profit-maximizing institutions. Almost everywhere now their primary objective is to maintain price stability. Central banks do, nevertheless, care about their balance sheets, in particular their profit and loss account, because avoiding losses is important to preserve independence, which ensures our ability to fulfill our mandate. Lorenzo Bini Smaghi, former ECB Executive Board Member, in 2007 reiterated this importance since, I quote: “A central bank cannot credibly operate in an independent way without proper financial means; it would be under a 'Damocles' sword' if it depends on the government for the financing of its operative expenses."

Therefore, the lower return on FX assets may become problematic if the lower returns structurally undermine the central bank's profitability.

Although several strategies can be theoretically envisaged to temper the effects on profits of the negative euro area interest rates, such as currency diversification, they can hardly be deployed in the region without partially undermining the role FX reserves play.

What we can, do, however, is to right-size the level of FX reserves. In Albania, we are very proud of having recently adopted a state-of-theart FX reserve optimization model with support from IMF technical assistance (TA). This ensures that our FX reserves are adequate to meet all possible contingencies for which reserves are needed, but it prevents us from holding more than we need taking into account FX reserve opportunity costs.

These challenges are not unique to the region, but are probably shared with several countries in proximity of the euro area and beyond, from which we will also hear today.

We have a very qualified panel to discuss the reserve management challenges in the current low interest rate environment and the varying responses of different central banks.

We start with Roberto de Beaufort of the World Bank. Roberto is the Lead Financial Officer of the Reserves Advisory and Management 
Program (RAMP), responsible for managing the technical assistance program for central banks and sovereign wealth funds of member countries. Roberto has been several times in Albania. We will benefit from the unique breadth of his cross-country experience.

We have then Victor Andrei, Head of the Market Operations Department of the National Bank of Romania, and Sándor Ladanyi, of the Monetary Policy Instruments, FX Reserves and Risk Management Directorate of the Hungarian Central Bank. Romania and Hungary are two countries in the EU, with strong economic and financial links to the euro area, with an Inflation Targeting framework and flexible exchange rates. They have, therefore, several similarities with countries in the region, like Albania and Serbia. 
This page intentionally left blank 


\section{ARE YOU PREPARED TO ASSUME THE RISK OF INCREASING EUR YIELDS? ${ }^{1}$}

Roberto de Beaufort Camargo World Bank, Lead Financial Officer

\section{INTRODUCTION}

I would like to thank the Bank of Albania, the IMF, and the Swiss Embassy for your kind invitation to speak at this forum. I was quite interested in the various discussions on the macroeconomic vulnerabilities of highly euroized economies in the context of negative euro area interest rates. These discussions provide a good background for my presentation on reserve management in the region.

In order to address the issue of negative euro area interest rates on the return of reserves, rather than discussing investment strategies designed to enhance the income on reserve management in this environment, which I suspect most central banks in the region have already considered, I would like to focus on the risk that these strategies entail given the external vulnerabilities that highly euroized economies are exposed to in a rising interest rate scenario. The reason for taking this approach is to emphasize that, first and foremost, reserves serve an insurance purpose, and as managers of insurance, central banks need to ensure that the level of risk-taking in the management of these funds is consistent with the size and nature of their external vulnerabilities.

I would like to begin my presentation with a description of the current market consensus on the trend of interest rates in the euro

This presentation has been prepared by the Treasury of IBRD (TRE) for working purposes for the clients participating in the $\mathrm{R} A M P$ program to guide them in understanding certain concepts underlying investment management. It does not represent, and shall not be interpreted as, specific advice or recommendation as to any particular matter covered herein, nor as an indication of market standard in a particular area. Nothing contained in the presentation constitutes or shall be construed as a representation or warranty by IBRD. 
area, then discuss specific reserve adequacy indicators for highly euroized economies as the basis for defining the risk tolerance with which reserves are managed and, lastly, the risk in a rising yield environment of investment strategies designed to enhance returns in a negative rate environment.

\section{MARKET CONSENSUS ON THE TREND OF INTEREST RATES IN THE EURO AREA}

As we all know, the prevailing forecast is that euro yields will be positive in the next three years. This is not necessarily a World Bank view, but the view of the consensus of the market. In accordance with the latest European Commission Economic Forecast (Figure 1), for the first time in a decade the economies of the EU member states without exception are expected to grow, bar any political surprise from another member state. After the French elections last week, President Draghi announced that he might be considering ending the ECB's tapering plans sooner rather than later. However, after Brexit, political uncertainty is likely to persist and the focus may now shift toward the approaching Italian elections next year. But what drives this consensus?

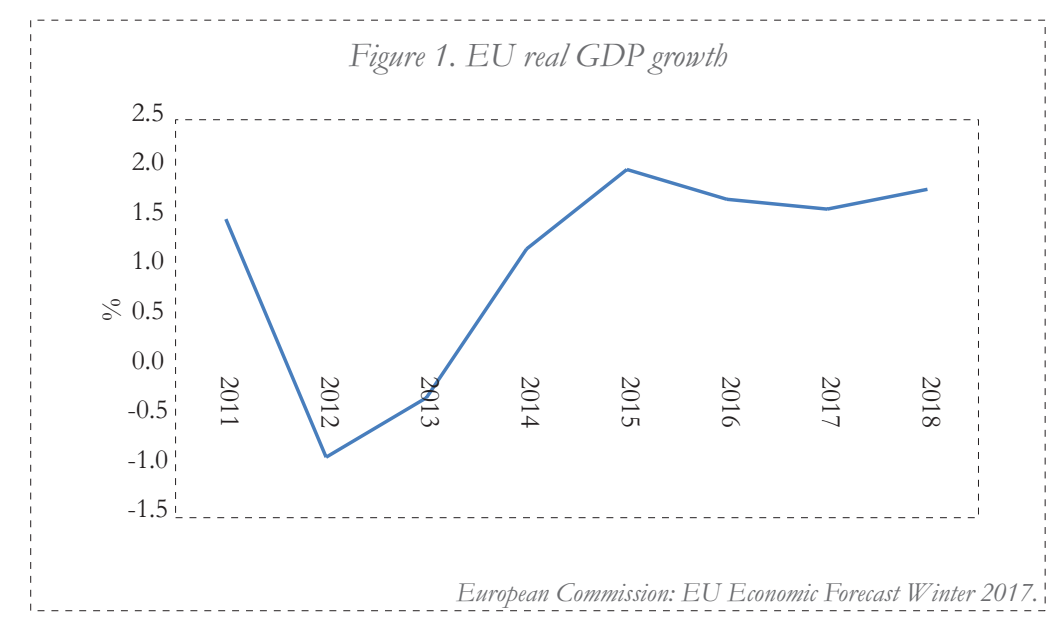

- Private consumption has been the engine of the recovery (Figure 2). Private consumption has been supported by robust 
employment growth and increases in compensation, while public consumption is expected to continue providing stable support (Figure 2)

Figure 2. EU private and public consumption

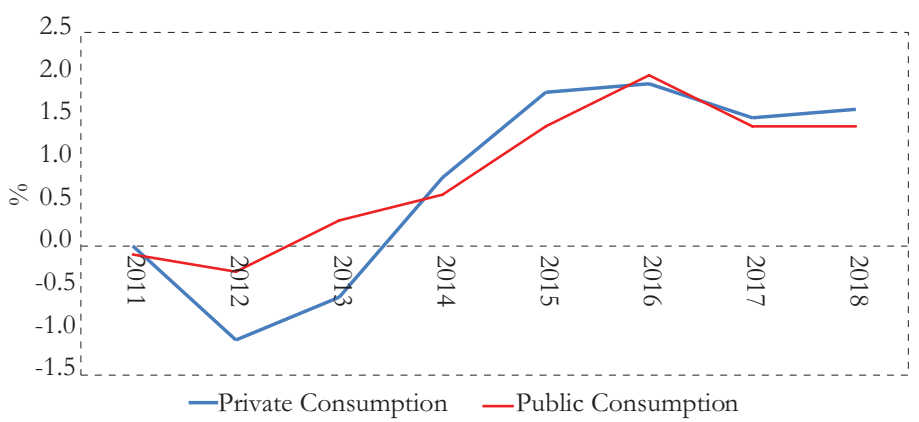

European Commission: EU Economic Forecast Winter 2017.

- Investment growth has recovered, but remains subdued notwithstanding substantial policy support and the improvement of financing conditions. Brexit, uncertainty on the outcome of the elections in France, and the ongoing process of corporate deleveraging may explain the disappointing growth of investment. But going forward, there is a reasonable expectation that investors' confidence should pick up as the economy continues to grow and financing costs remain low (Figure 3).

\section{Figure 3. EU investment}

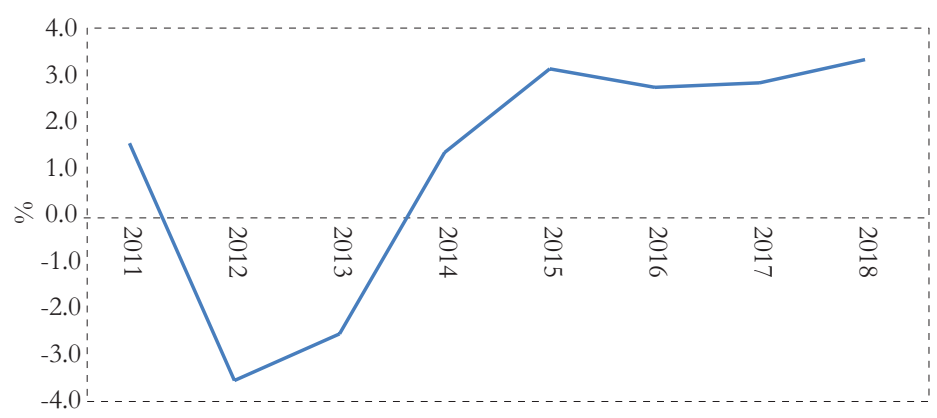


- The contribution of net exports to growth is expected to be neutral. Exports have gradually increased, supported by the recovery in global demand, particularly in the US and emerging markets, but imports have increased at the same pace given the recovery of private consumption (Figure 4).

Figure 4. EU trade

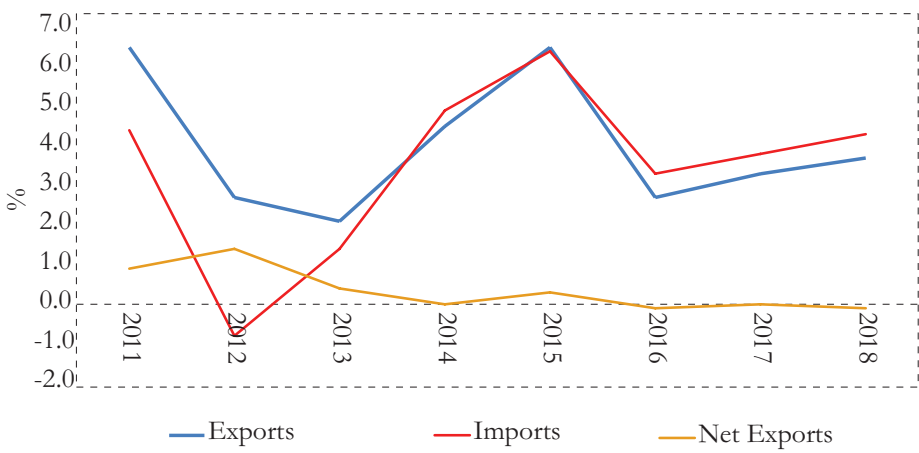

European Commission: EU Economic Forecast Winter 2017.

- Inflation is expected to be below the 2 percent ECB target and inflation swap rates at the three-year forward three-year ahead horizon price an average inflation of 1.4 percent (Figure 5)

Figure 5. EU inflation

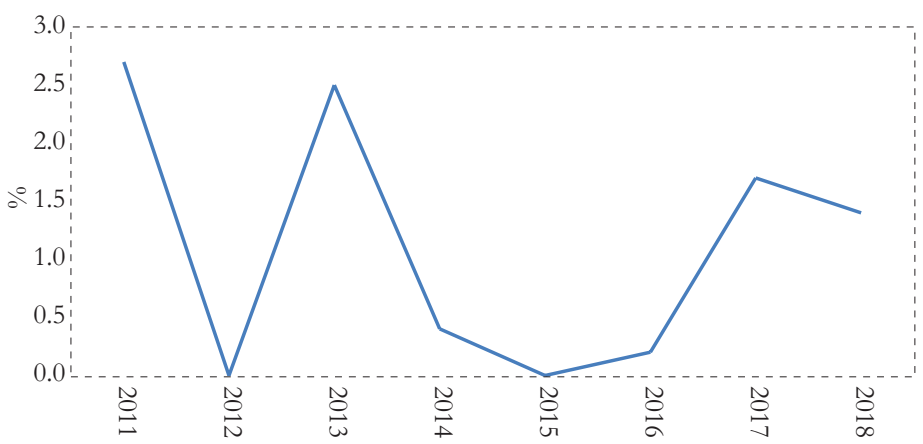

European Commission: EU Economic Forecast Winter 2017. 
Given the above, market consensus predicts that, barring a political surprise like Brexit, the gradual economic recovery will induce the ECB to announce in Q4 the end of its QE tapering plan for 2018. In response to this, the yield curve is expected to be less negative next year (Figure 6). In three years, the concensus expects that the yield curve will be positive, while short-term rates remain close to zero (Figure 7).

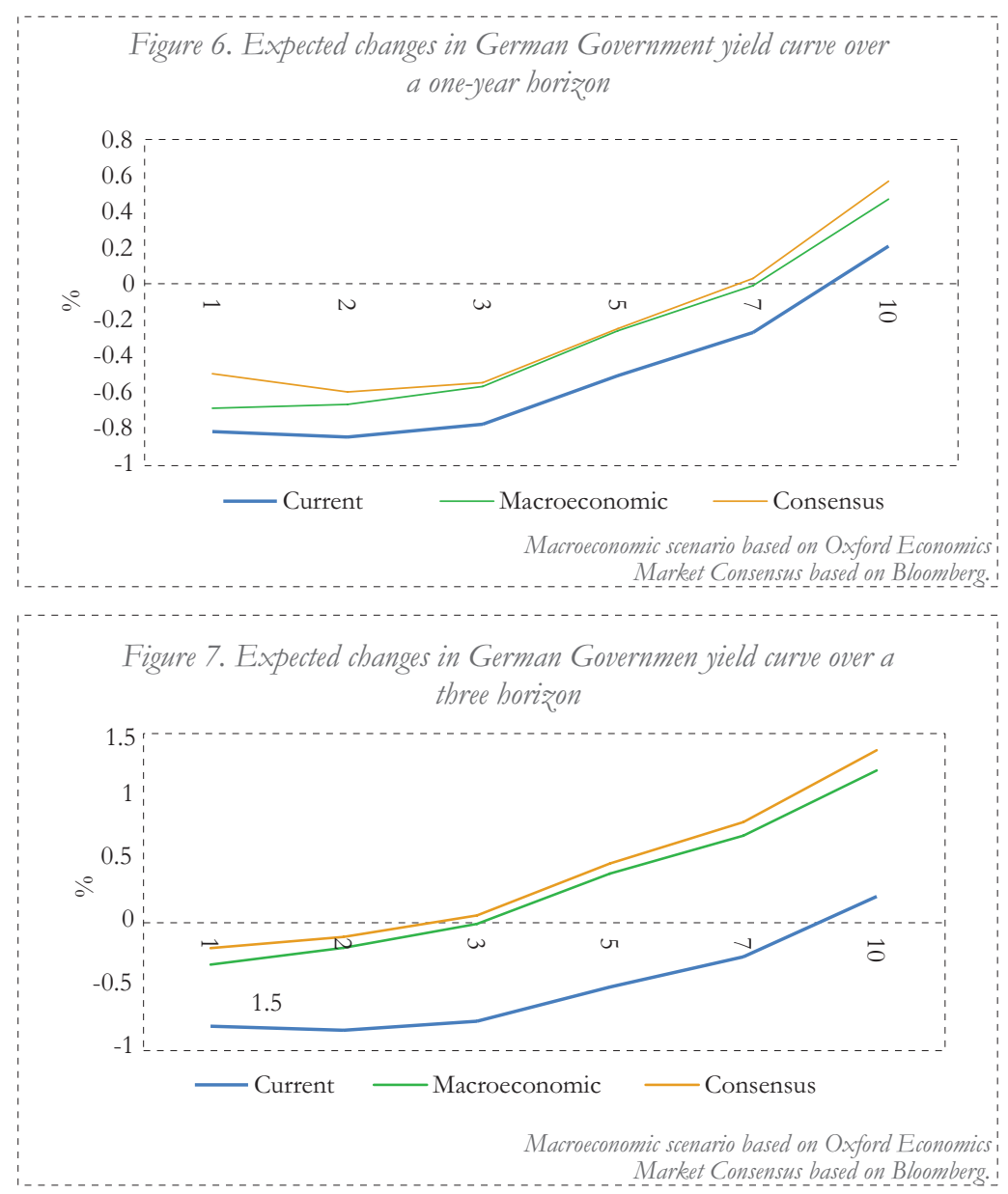

Given the above, what would be the risk of strategies to enhance returns in a negative interest rate environment in a rising yield consensus scenario? Before addressing this question, I would like 
to first assess the risk taking capacity of a central bank to manage its reserves on the basis of an assessment of a country's external vulnerabilities.

\section{RESERVE ADEQUACY AND RISK TOLERANCE}

What could the impact be in the region, and indeed in all developing countries, of higher interest rates in the euro area and in the US? During our Reserve Advisory and Management Program (RAMP) Executive Forum last week, President Trichet warned that low interest rates have pushed the boundaries of risk for international investors looking for returns. He foresaw that the next global crisis could very well come from emerging markets, both from the significant increase of capital flows to emerging markets in a low interest rate environment and unsustainable debt to GDP ratios. Furthermore, Mohamed El-Arian warned that global risks have increased considerably, characterizing the future as a camel with two humps, meaning two fat tails, and central banks will need to manage the reserves in an environment where abnormality is the norm. The fundamental question then becomes whether developing countries have enough reserves to adequately hedge a potential reversal of capital flows, harder access to refinance debt rollovers, global shocks, and, in the case of highly euroized or dollarized economies, risks to the stability of their financial systems vulnerable to significant currency mismatches, as we have already observed in some Western Balkan countries.

In the case of the Balkan region, it is difficult to generalize a single measure of reserve adequacy given that each country has different external vulnerabilities, exchange rates regimes, and EU membership status (Figure 8). In this presentation, I will mainly focus on countries with a floating exchange rate arrangement. 
Figure 8. Western Balkean FX regimes and EU membership status

\begin{tabular}{|l|l|l|}
\hline Country & FX Regime & EU Membership Status \\
\hline Albania & Float & Candidate \\
\hline Serbia & Float & Candidate \\
\hline FYR Macedonia & $\begin{array}{l}\text { Managed } \\
\text { Arrangement }\end{array}$ & Candidate \\
\hline Croatia & $\begin{array}{l}\text { Managed } \\
\text { Arrangement }\end{array}$ & Joined the EU July 2013 \\
\hline Bosnia and Herzegovina & Currency Board & Potential Candidate \\
\hline Montenegro & EUR & Candidate \\
\hline Kosovo & EUR & Potential Candidate \\
\hline
\end{tabular}

I shall also use as a measure of reserve adequacy, the IMF's assessment of reserve adequacy model (ARA) comprising the following indicators with the weights shown in Figure 9:

- Exports: to hedge the risk of a potential loss of export income as a result of a drop in external demand or a shock in the terms of trade.

- Short-term debt (STD): to hedge debt rollover risk.

- Other liabilities: to hedge the risk of non-resident capital outflows as a result of the liquidation of domestic equity holdings and medium- to long-term debt holdings in domestic currency.

- Broad money: to hedge the risk of resident capital flight.

\section{Figure 9 ARA weights}

\begin{tabular}{|l|c|c|c|c|}
\hline \multicolumn{5}{|c|}{ ARA Weights } \\
\hline FX Regime & Exports & STD & $\begin{array}{c}\text { Other } \\
\text { Liabilities }\end{array}$ & $\begin{array}{c}\text { Broad } \\
\text { Money }\end{array}$ \\
\hline Fixed Rate & 10 & 30 & 20 & 10 \\
\hline Floating rate & 5 & 30 & 15 & 5 \\
\hline
\end{tabular}


The ARA model is a considerable improvement over the GreenspanGuidotti rule for reserve adequacy, based on short-term debt plus a measure of current account volatility. I also believe that the ARA model is more relevant to developing countries because it incorporates the importance of non-resident capital flows, as capital markets have become more open, and the broad money measure incorporates financial stability concerns, especially relevant to highly euroized and dollarized economies.

In accordance with the ARA model, as observed in Figure 10, most countries in the Western Balkan region with floating rate regimes hold reserves within the target band defined by the model.

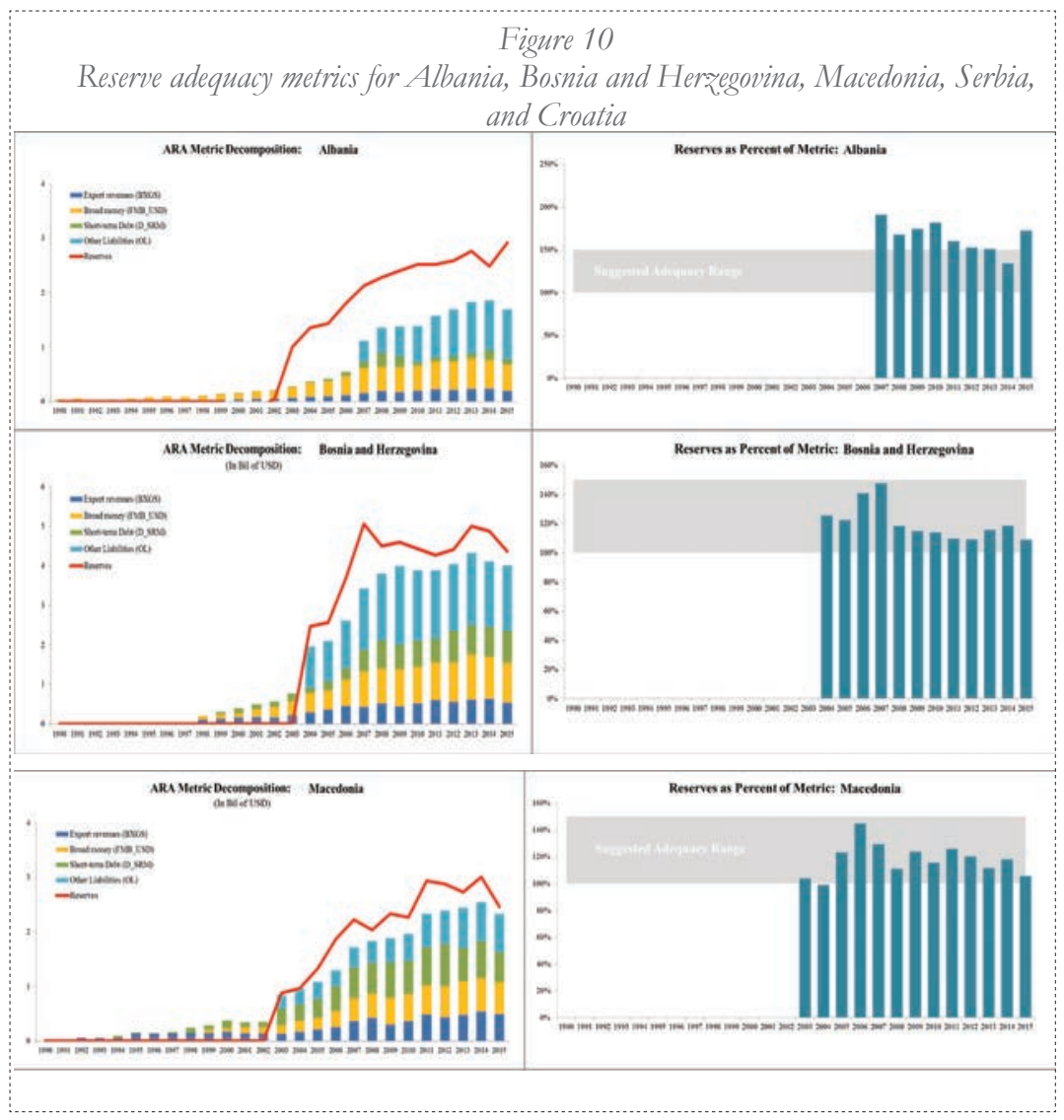




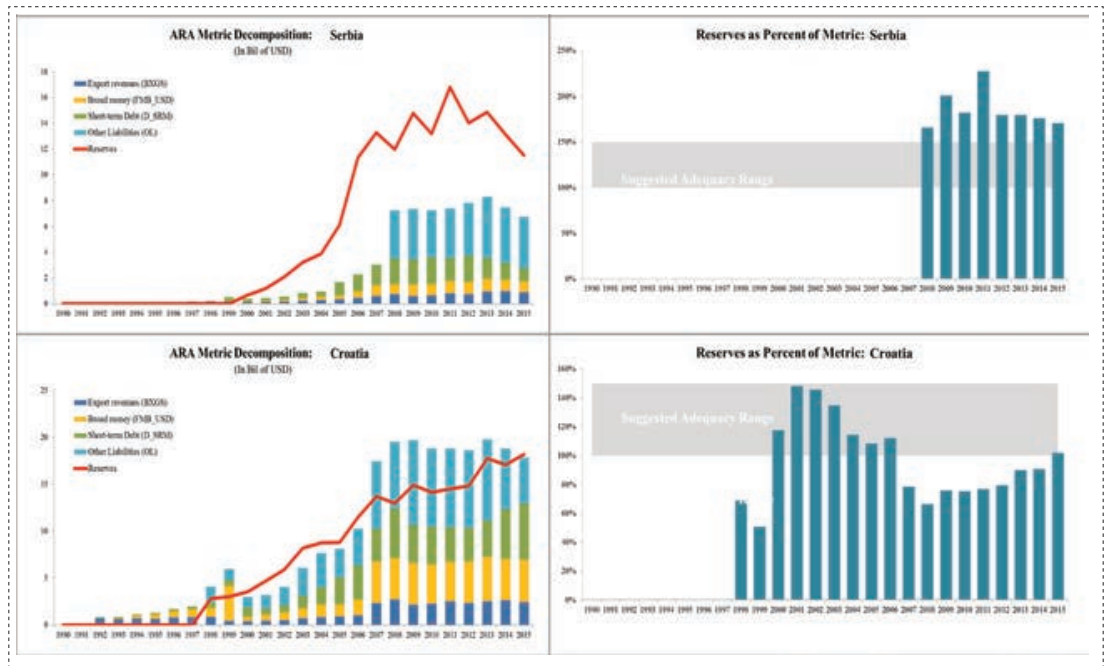

The fact that reserves in the region are within the adequacy range used by the ARA model has profound implications for the risk tolerance with which they are managed. But before delving into the specifics of the region, the following global generalizations could be relevant:

- In countries with flexible exchange rate regimes, accumulating reserves within an adequate range is necessary to preserve the credibility of monetary policy, but the tolerance to liquidity, market, and credit risk is usually higher, as intervention is designed to only smoothen excessive exchange rate volatility.

- In countries with managed currency arrangements, not only maintaining reserves within an adequate range is highly relevant, but also their tolerance to liquidity, market, and credit risks is typically lower.

- The insurance motive for holding reserves to manage fat tail events, for example, disruptions in international markets and political events, affects both.

In the case of highly euroized or dollarized economies, even those with inflation-targeting regimes, the vulnerabilities captured by the ARA model provide some insights into their specific vulnerabilities that could be used in setting the tranching structure of the portfolio 
comprising: (1) a highly liquid low-risk Working Capital Tranche for day-to-day intervention; (2) a Liquidity Tranche invested in liquid assets with a short-term capital preservation objective; and (3) an Investment Tranche invested in less liquid assets with a longer than one year capital preservation objective. In this respect, I would like to make the following observations:

- Particularly after the financial crisis, portfolio flows have increased significantly, increasing the exposure of the region to non-resident capital outflows and potentially requiring higher low-risk liquidity buffers. Non-resident capital flows are procyclical, raising vulnerabilities and amplifying external shocks, of which portfolio investments represent the more volatile component. As observed in Figure 11, before the financial crisis capital flows reached the equivalent of 25 percent of GDP, predominately because of FDIs and bank lending consistent with the expansion of foreign bank networks in the region. After the financial crisis, capital inflows collapsed below 10 percent of GDP, but portfolio debt flows increased.

Figure 11. Western Balkan-resident capital inflows, \% of GDP

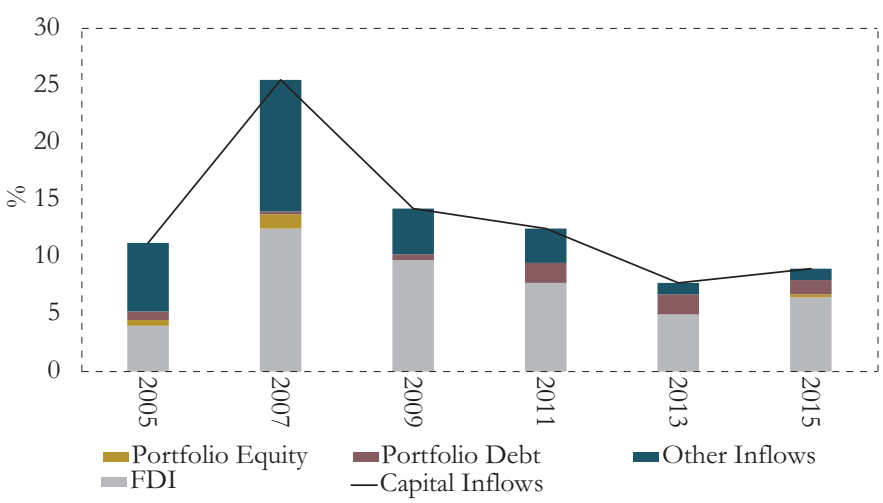

- As observed in Figure 12, the region has high debt-to-GDP ratios, and at least half of this debt is denominated in a foreign currency. However, all of the countries in the region meet the yardstick for holding enough liquid reserves to cover at least short-term debt amortizations. In this respect, many central banks have established coordinating committees with 
the Ministry of Finance to ensure that debt repayments are smoothened over time.

Figure 12. Debt-to-GDP ratio and reserves/Short Term Debt
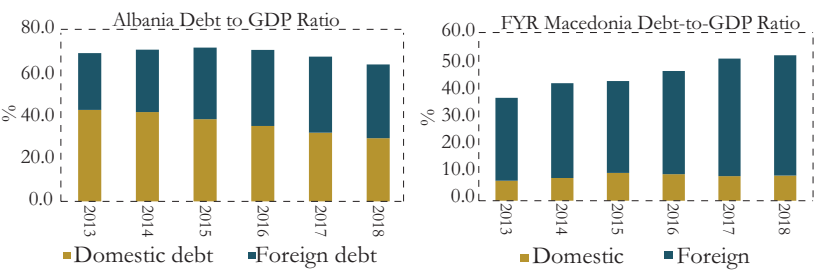

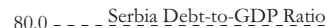
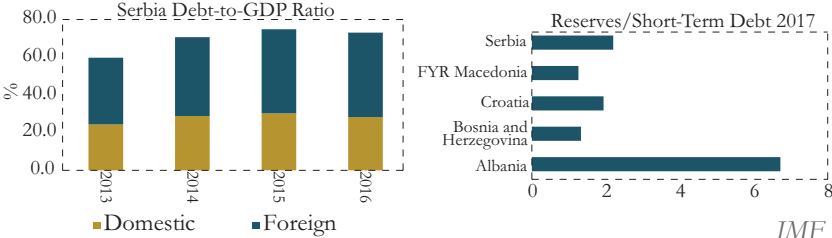

IMF dataBase :

- Indicators of the soundness of the financial system (Figure 13), as well as the robustness of macro-prudential safeguards such as the existence of regulatory deposits, can provide useful information on the allocation of this metric to the Liquidity and Investment tranche. Although the Western Balkan banks appear well capitalized, hold high liquidity-to-short-termliabilities ratios, and maintain a high level of regulatory deposits in the central bank, the region has suffered bouts of high levels of non-performing loans, currency mismatches, and contagion from parent companies abroad.

\section{Figure 13. Financial system indicators}
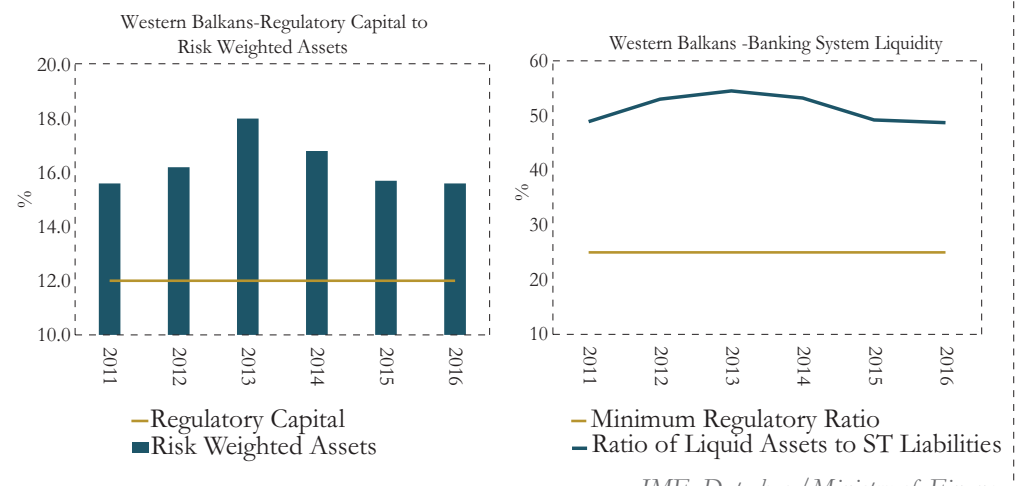

IMF Data base/Ministry of Finance.. 
- The exchange rate competitiveness indicator may not be as relevant to central banks in countries with floating rate regimes in the Balkan region. However, an assessment of the degree of depreciation or appreciation of the exchange rate relative to the currencies of its main trading partners can provide useful information on the allocation of funds to the Liquidity and Investment tranches.

Considering the above, the risk bearing capacity of central banks in the region may be tempered by the fact that the level of reserves is in most cases within the ARA reserve adequacy metrics. Furthermore, the nature of the vulnerabilities of each country in the region may also limit the risk-taking capacity of central banks to manage their reserves within the reserve adequacy range, in particular because of financial stability concerns given the high level of euroization.

\section{THE RISK OF INVESTMENT STRATEGIES TO ENHANCE RETURN IN A NEGATIVE RATE ENVIRONMENT.}

In the current negative interest rate environment, the need for income generation and the limited risk-bearing capacity of central banks in the region poses a challenging problem. On the one hand, reserve managers may argue that negative income generation weakens central bank balance sheets and, at the extreme, may indirectly hamper the accomplishment of their fundamental objectives unless the central bank charter, like the one governing the central bank of Albania, obliges the government to finance the central bank with the issuance of interest-bearing domestic bonds while this situation persists. On the other hand, the managers of monetary policy may argue that increasing the risk tolerance beyond a level that is consistent with the size and nature of their contingent liabilities may expose the central bank to the realization of significant losses if risky investments are required to be liquidated before maturity to cover a potential need for intervention.

One way to resolve this conflict is by measuring the potential risk to future returns of different investment strategies designed to enhance returns in a negative rate environment - duration, credit spreads, and currency - should the consensus view of the market occurs. 
In the case of duration, the steepness of the yield curve provides an opportunity for reducing the impact of negative yields by simply increasing the duration of the portfolio. To assess this risk, we analyze the impact on returns of portfolios with increasing durations if yields of German Government bonds, increase as forecasted by the consensus over a one- and three-year investment horizon, as shown in Figure 14.

\section{Figure 14. Consensus forecasts}
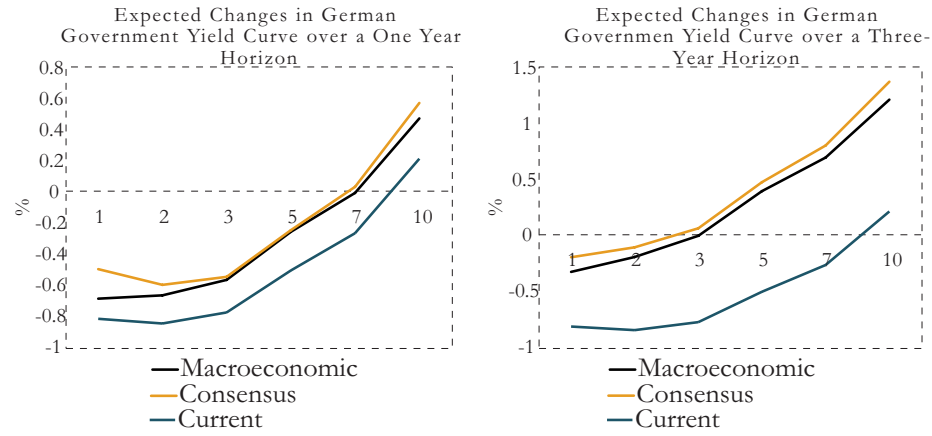

Macroeconomic scenario based on Oxford Economics! Market Consensus based on Bloomberg.

The results are not surprising. Duration strategies do improve shortterm returns given the steepness of the curve, but will forgo future returns if there is a normalization of the yield curve. Over a oneyear investment horizon (Figure 15), the C-VaR looks progressively worse even though yield increases are not significant, mainly because the portfolio does not benefit from positive carry. Over a three-year investment horizon (Figure 16), the losses worsen considerably for the same reason. The question then becomes whether it is preferable to accept negative rates now by investing in short duration securities, rather than face bigger losses in the future if the yield curve normalizes. 
Figure 15. Duration risk over a one-year investment horizon (annualized)

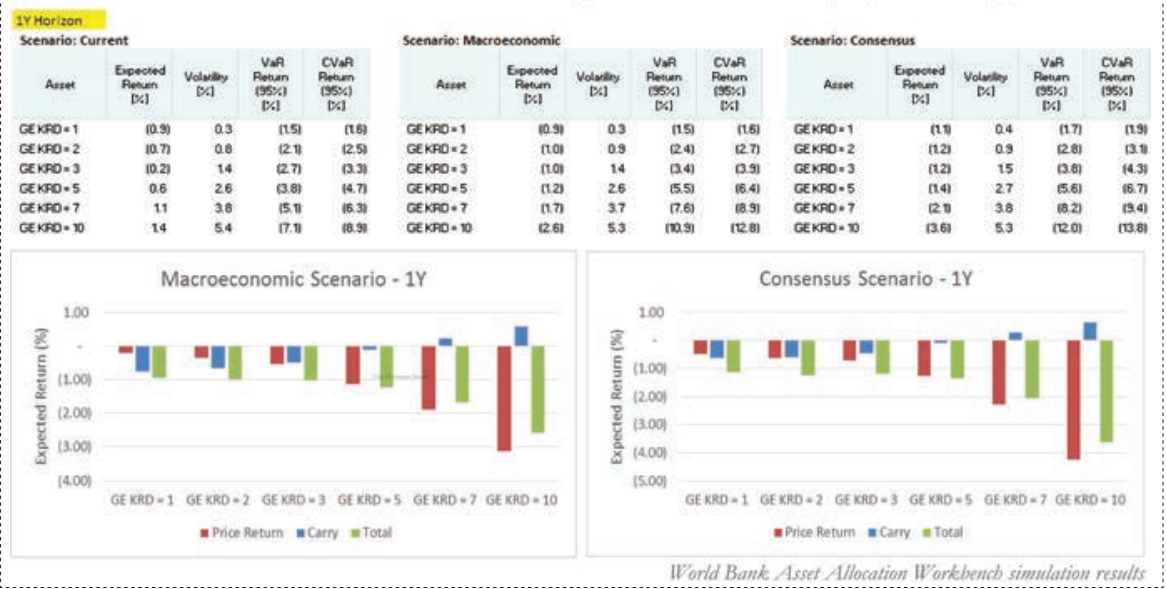

Figure 16. Duration risk over a three-year investment horizon (annualized)

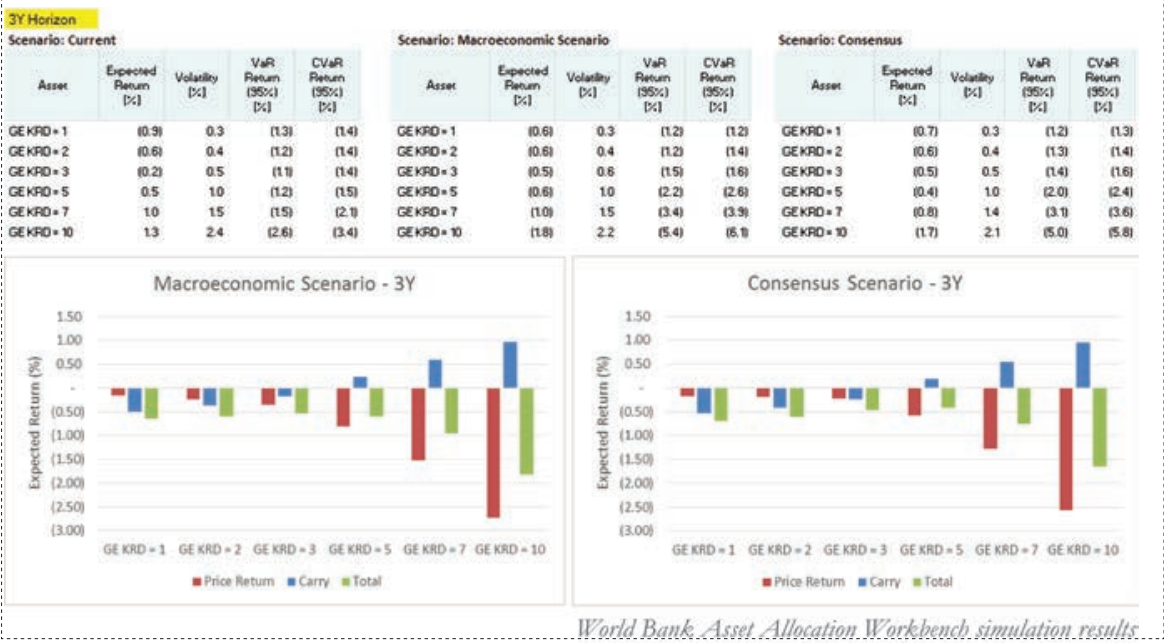

In the case of spread strategies, as shown in Figure 18, the consensus predicts a slight increase in spreads. Since this strategy benefits from positive carry in a magnitude that depends on the credits chosen, the returns of the portfolio benefit both in the current negative rate environment and in the future (Figure 19). However, investing in credit spreads exposes the portfolio to the non-systemic risk of investing in a "bad apple," which can be managed through diversification, but may not address reputational risk. To illustrate this 
point, some central banks, including the central bank of Colombia, invested in a well-diversified portfolio of corporates before the financial crisis. During the financial crisis, a default occurred worth 10 basis points of the value of the portfolio and, although the loss had been compensated by the additional returns accrued over the whole portfolio, to this day the decision has been questioned by the public, and the central bank has undergone several investigations.

Figure 17. Eastern European spread over two year German Government bond

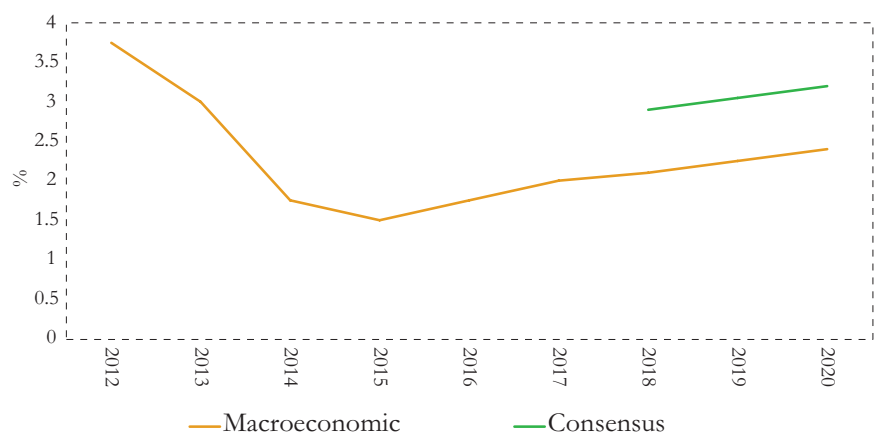

Based on projected spreads of Eastern European countries that are! part of the EU but not in the eurozone.

Figure 18. Spread risk over a one and three-year invesment horizon using two-year bonds

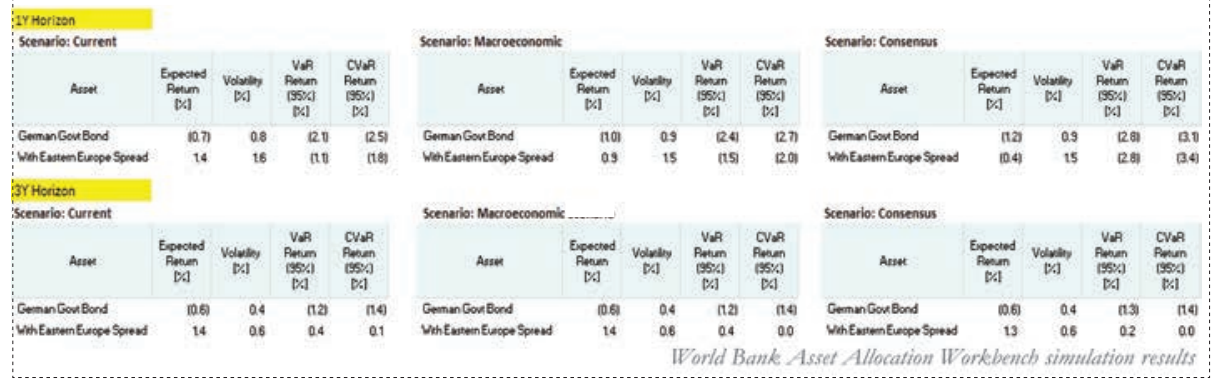

An alternative used by central banks to reduce the impact of negative returns on their reserve portfolios is to invest in currencies that are not necessarily their natural numeraire to benefit from positive carry. This is a more complex strategy to assess from a balance sheet perspective. In most central banks, accrued income benefits the income statement, but exchange rate changes relative to the local currency are usually registered in equity in a currency stabilization 
account in order to avoid monetization. In other words, foreign exchange strategies can improve income, while, at the same time, deteriorate the capital of the central bank, and, as such, they should be treated with care.

In most central banks, the currency composition of core reserves (defined as reserves within the reserve adequacy range) seeks to preserve their value relative to the macro vulnerabilities of the country. As such, in setting the currency composition, central banks consider the denomination of foreign debt, trade, and the currency of intervention, among other variables. In highly euroized or dollarized economies, the currency composition is heavily influenced by such, currencies. By following an asset-liability management approach for the selection of the currency composition of a reserves portfolio, the impact on equity of changes in the value of these currencies relative to the local currency can be explained to the public and usually, over the long term, follows a countercyclical behavior. When the local currency appreciates relative to these currencies, the probability of intervention is lower and the capital of the central bank accumulates unrealized losses. In the opposite case, when the local currency depreciates, the probability of intervention is higher and the central bank can potentially register realized gains. This may not be the case when a central bank invests core reserves in currencies with a positive correlation to the local currency, for example, by investing in high-yielding commodity currencies.

As can be observed in Figure 19, investing in Australian dollars generates higher cumulative income relative to investing in German Government bonds, as well as provides diversification benefits, but exposes the portfolio to a much higher volatility against the predominant reserve management numeraire in the region. 
Figure 19. Return and risk of investing in non-Euro currencies
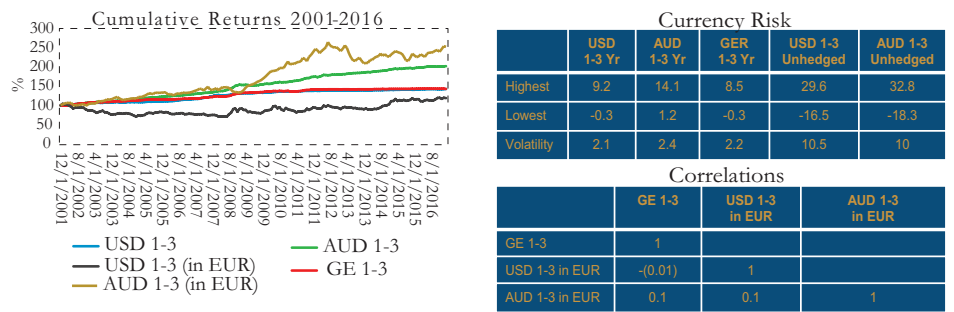

$1 \mathrm{Y}$ Rolling returns (\%) - USD 1-3Y Index
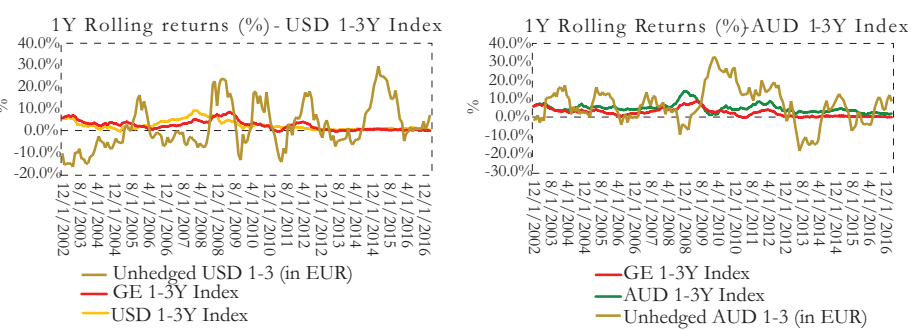

However, central banks that hold reserves beyond precautionary needs, and are confident that these reserves will not be used for intervention over investment horizons longer than one year, have looked at different rationales for minimizing the cost of accumulating reserves beyond an "insurance" purpose. Some of the objectives used by central banks are:

- Hedge the balance sheet from non-euro-denominated external debt contracted by the central bank, such as IMF loans.

- Hedge public debt contracted in other currencies, as part of a strategy to reduce inefficiencies in the consolidated balance sheet of the central bank and the government.

- Protect the balance sheet of the central bank and increase income by investing in high-yielding currencies with a positive correlation to the local currency. 


\section{CONCLUSIONS}

I would like to conclude my presentation by reemphasizing that when it comes to core reserves, as defined by their reserve adequacy target, it is of fundamental importance that they are managed with a risk tolerance that is consistent with the contingent macro risks that they are designed to cover. Furthermore, the analysis of the specific external vulnerabilities of each country using the ARA model, or other reserve adequacy methodologies, is fundamental in defining the tolerance to market, credit, and liquidity risks with which reserves should be invested. Not to do so can expose central banks to the realization of significant losses at a time when it needs reserves the most. Income considerations, while important, are secondary in this case. However, in the case of central banks that have either excess reserves over core needs, or feel that they have sufficient short-term liquidity to invest a portion of reserves over longer investment horizons, they can and do invest the reserves with a higher risk tolerance and different rationales in order to reduce the cost of accumulating reserves beyond short-term contingent needs. 


\section{NEGATIVE EURO AREA INTEREST RATES AND RESERVE MANAGEMENT AT THE CENTRAL BANK OF ROMANIA}

Victor Andrei

National Bank of Romania, Market Operations Department, Director

\section{INTRODUCTION}

I will start by thanking the organizers, the Bank of Albania, the IMF, and the Swiss Government, but I would also like to congratulate them on organizing such an event. I guess we all agree that such an event is useful for everybody to share our experience.

\section{SETTING THE STAGE}

Just to set the stage, Romania's foreign trade takes place mostly with European countries, as it is probably the case with most of the countries represented at this conference. The latest data are showing that Romania's 86 percent of exports and 89 percent of imports take place with European countries as a whole. With the other $27 \mathrm{EU}$ member countries Romania has around 75 percent of exports and 77 percent of imports. This is one of the reasons for which in the Central Bank of Romania's investment strategy the benchmark share of euro has ranged for almost a decade between 55 percent and 85 percent of total foreign currency reserves, while, euro actual reserve holdings have ranged between two-thirds and three-quarters of our total foreign currency reserves.

Coming back to the euro negative rates spillovers, you can imagine that such a high percentage of foreign currency reserves invested in euro poses a real challenge for the foreign currency reserves management. I won't elaborate on the reserve adequacy, which, in the case of Romania, has been appropriate even during the crisis. We are currently complying with all traditional metrics of reserve adequacy ${ }^{1}$.

$\overline{{ }^{1} \text { Months of imports, short-term debt payments coverage, IMF-ARA (Assessing Reserve Adequacy).. }}$ 


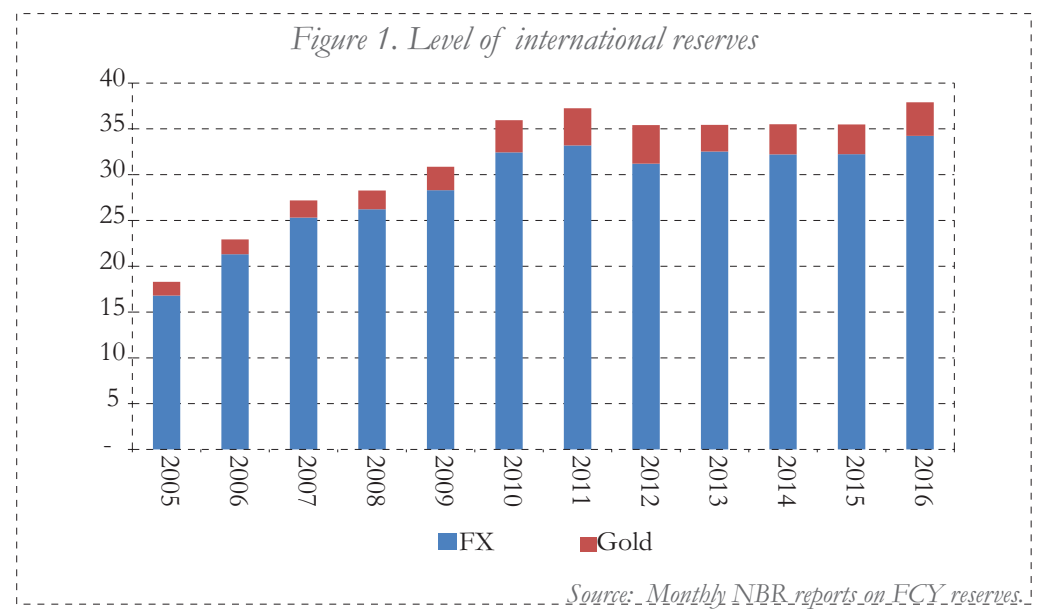

You can see in Figure 1 that we had a significant increase in the level of foreign currency reserves in the period 2005-2011. I will briefly explain the main reasons behind it.

We joined the European Union in 2007. In the first couple of years, we were net payers to the EU budget. Afterward, as we gained some experience and some EU-funded projects were launched, we reversed the net position vis-à-vis the EU budget. For instance, last year we had more than 5.5 billion euro inflows. Overall, since joining, we have had approximately 20 billion euros equivalent net inflow, which contributed to such a sizeable level of foreign currency reserves.

The main outflow during the period was the repayment of the loan granted by the IMF, after the crisis, which is now fully repaid. The main sources for the FCR nowadays are the European Commission funds, earlier mentioned, and the euro bonds issued by our Ministry of Finance.

The gradual decrease of the minimum reserves requirements for foreign currency deposits from a maximum of 40 percent to a single-digit number at the present has represented during the period another source of foreign currency reserves outflows. In fact, FX assets held by commercial banks for reserve requirement fulfillment purposes contributed to gross reserves. 
I will discuss now a little bit more about the management of those reserves.

Returning after a pause of 15 years to the central bank, I had to "rewire" my commercial banking and private equity mindset. Here at the central bank, the profit is not the most important objective. Liquidity and safety (as highlighted as well earlier by Roberto De Beaufort Camargo's presentation) are the main goals.

Having said that, and although the profit is definitely not the most important goal, while complying with liquidity and safety paramount objectives, foreign currency reserves are also expected to contribute to central bank's operating income with a view to maintaining a positive equity position.

In Figure 1, there are two components: the red part represents gold reserves, which have stood for many years at slightly below 104 tonnes. But depending on the exchange rate, the amount in euro, varies between approximately 3.5 billion and 4 billion euro. The gold is held partially abroad, and prior to the crisis we invested it regularly in short-term deposits.

At the end of March 2017, the level of the foreign currency reserves stood at more than 36 billion equivalent euro, increasing approximately 2 billion euro from the end of 2016 levels.

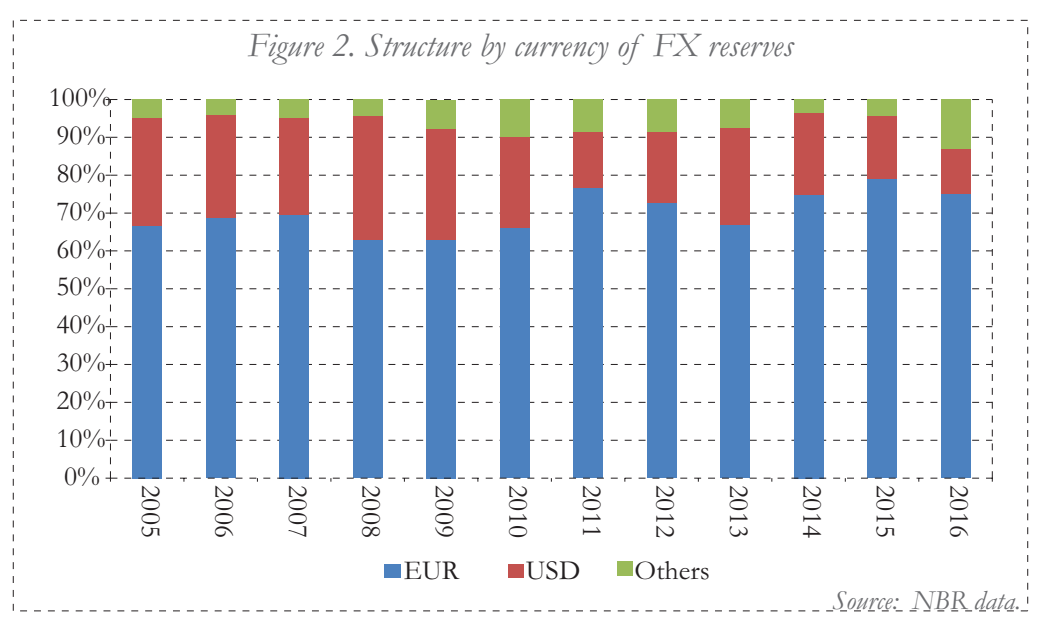


As you can see from Figure 2, providing a currency breakdown of the structure of foreign currency reserves, between two-thirds and almost 80 percent of the Central Bank of Romania reserves are denominated in euro. The next currency in terms of relative weight is USD for which we maintain as per the current strategy between 10 percent and 35 percent of the total foreign currency reserves. All other currencies can represent between 20 percent or less. We are in constant discussions internally to explore the scope for further currency diversification.

As most of you would probably expect, the "other currencies" were some time ago mainly the British pound and the Japanese yen. Recently we did diversify to other currencies that are common among the central banks.

\section{THE KEY STRATEGIC OBJECTIVES: CHANGES FOR THE 2009-2010 PERIOD}

I will briefly mention the most salient features of our FCR management strategy in 2009-2010. The investment horizon was one year, and the modified duration of the portfolio was six months. The share of euro could fluctuate in a range of 55 percent and 85 percent of total foreign currency reserves and the US dollar between 10 percent to 40 percent of the total foreign currency reserves. The "other currency" part of the foreign currency reserves was at most 10 percent of the total. We included here as well the special drawing rights that we have as an IMF member country.

In terms of eligible issuers, we used to have the standard issuers, of very good quality and very high creditworthiness, therefore we incurred in minimum credit risk on our debt holdings. Since then, we have kept what we had before, at least in theory, 10 percent exposure to issuers of covered bonds and to private entities. However, although we did not lose any penny or cent, our board decided after the crisis, to temporarily suspend the eligibility of unsecured deposits placed with private entities - and since then, the suspension has remained in place. Unsecured money market deposits with private counterparts are still formally eligible as a management instrument in our FCR management strategic guidelines, but we need a formal approval from the board to restart placing them. 


\section{THE KEY STRATEGIC OBJECTIVES: CHANGES FOR THE 2011-2015 PERIOD}

We had some changes in 2011, after we drew the IMF loan that I mentioned earlier. The investment horizon has been increased from one to five years. But I guess that it is important to mention that we had an average modified duration of only six months. As you can see, we were at that time and we still probably are among the most conservative central banks in the region. And the colleagues from RAMP can probably certify that.

We increased the weight of "other currencies" to at most 15 percent from 10 percent and slightly reduced the maximum weight of dollars to at most 35 percent from 40 percent. We also added the Government of Japan to the list of eligible issuers.

\section{THE KEY STRATEGIC OBJECTIVES CHANGES FOR THE 2016-2017 PERIOD}

What we further changed in 2016 is the use of a "three tranches" approach. We also extended the overall portfolio modified duration to 1.25 years - but that increase is due mostly to the investment tranche. New eligible currencies were also introduced. Still, there are no derivative products allowed - not even the plain vanilla ones. So we still have to work to convince our decision making bodies of the usefulness of including plain vanilla instruments for hedging interest rate and/or foreign currency risk in the list of eligible instruments for FCR management-and that is probably the case with some of your countries.

What we managed to do was to slightly increase the "other currencies," weight to at most 20 percent (from 15 percent) of foreign currency reserves. And we relaxed the issuer risk constraint to accommodate a combination of increased duration, although one year and a quarter is far away from three, four, or even seven years that some of the central banks in the EU have. But we still increased the modified duration in combination with slightly greater leeway in terms of credit risk, which enabled us to play to a certain extent 
the spread game mentioned earlier in the presentation by Roberto de Beaufort. Exposure to private counterparts is still suspended for the time being. However, we convinced the board and the investment committee to grant portfolio managers greater leeway for more active tactical trading while accepting the obvious risk that comes with it. In this regard, I need to mention that - unfortunately, from the perspective of portfolio managers - unlike several other central banks, the treatment of the mark-to-market profit and loss is asymmetric at the Central Bank of Romania: negative mark-tomarket is charged directly into the income statement, while positive mark-to-market is considered unrealized.

So, yes, we have to be very careful with those potential swing effects, as they can be quite sizeable (not many years ago we incurred a yearly loss, but luckily, we recovered the next year the full amount with a profit). The pattern in terms of income and annual yield, displayed in Figure 3, is probably more or less in line with the pattern you have at your own central bank.

Figure 3. Returns on foreign exchange reserves - revenues (LHS, million euros) and annual yield (blue, RHS. \% per annum)

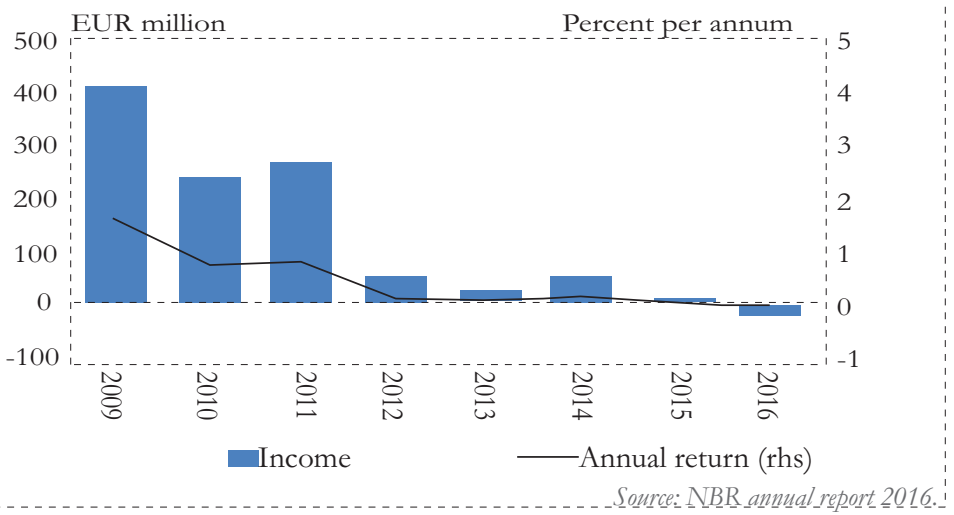

And, as is the topic of today's conference, the euro area spillovers, one can guess from Figure 3 in which year the interest rate on the euro became negative. It is the first year when the return on foreign currency reserves has turned a few basis points negative, but we managed to compensate for it with revenues from FX revaluation 
effects. So the total return is positive - but as I said, the profit is not the primary objective of a central bank.

I guess that it is important to highlight that while we repaid in full the IMF loan, the level of foreign currency reserves has increased. This comfortable level gives more confidence to the foreign investors, and it makes life easier for the Ministry of Finance to finance at lower costs and for longer tenors.

\section{CHALLENGES}

Of course, the challenges are the same as most of you have. Having approximately three-quarters of foreign currency reserves denominated in euro creates a big pressure on revenues. Although, in theory, everybody agrees that the role of the central bank is not to make profit, I am pretty sure that most of you, if not all of you, heard from time to time either from an executive or from a Ministry of Finance representative, the question: "What is the new amount that you will pay to the budget?" Indeed, 80 percent of our revenues goes to the budget.

Considering that the income generation on euro funds is actually negative, that the high liquidity/quality assets tend to yield even lower returns, we are facing higher opportunity costs for holding reserve assets and potential capital losses if rates normalize.

On the other hand, higher yielding assets may be too risky or volatile and significant losses can arise due to asset switches.

So, the real question is how much to increase the portfolio duration, expand the asset classes, and diversify the currency structure. 
This page intentionally left blank 


\section{IMPLEMENTATION OF THE NEW FX RESERVES INVESTMENT STRATEGY AT THE CENTRAL BANK OF HUNGARY}

Sandor Ladányi

Magyar Nemzeti Bank, Foreign Exchange Reserves Management Strategy

Department

It is a pleasure to speak at today's conference. I may raise more questions with my presentation than answers, but hopefully you will understand the general trends in reserve management and how the Central Bank of Hungary reacted to the negative yield environment.

An important disclaimer, I have to make: what I will present today expresses my own views and not necessarily the views of the Central Bank of Hungary.

\section{BACKGROUND AND MOTIVATIONS FOR THE}

\section{CONCEPTUAL CHANGE}

The background and motivations for creating the new investment strategy are "the usual suspects." Since the financial crisis, the financial markets and asset prices have been strongly driven by central bank policies, implemented by the major central banks. As a result, many emerging markets' central banks often earn negative returns on their traditional safe investments, and, at the same time, liquidity in the markets of key central banks' assets has been diminishing due to asset purchase programs and due to regulatory changes. So according to the Central Bank of Hungary's view, a central bank has to rethink its portfolio composition to avoid capital losses. 


\section{CHANGING THE INVESTMENT ATTITUDE OF CENTRAL BANKS}

So what happens when the preservation of the capital is in danger? In our view, you have to rethink the safety criterion from the safetyliquidity-return. Traditionally, the safety criterion meant that you had to focus on the left tail of the return distribution, on tail events, but what happens when the middle of the distribution is in negative territory? We think it is almost equally important to try to avoid smaller but certain losses than higher but unlikely losses on your reserves. We see that the general trend is that more and more central banks invest in riskier investments in order to achieve that goal.

\section{SPREAD COMPRESSION CAN SUPPORT OVERALL PERFORMANCE}

To have a broader picture of the balance sheet, we need to look at not only the asset side, but also the liability side. In Figure 1, you can see the spread difference between the one-year EUR benchmark and HUF base rate.

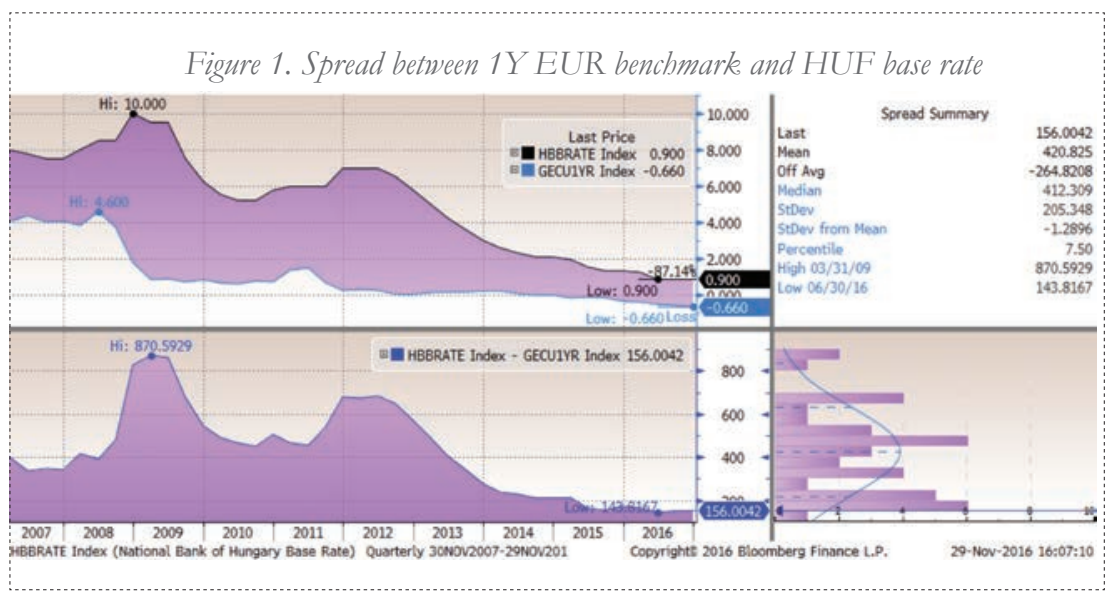

As you can see, the spread has significantly dropped in recent years, which means it has never been cheaper to hold reserves for Hungary and that is obviously a good side effect of this negative yield environment in Europe. But, the overall message is that regardless 
whether you have an asset-only perspective or an asset/liability perspective, holding your reserves incurs some kind of opportunity cost.

\section{BROAD APPROACH - BALANCE SHEET VIEW}

From a balance sheet perspective on the asset side, the FX reserve returns are 0 percent or below 0 percent due to the heavy concentration in the euro market. On the liability side, the financing cost is almost 1 percent. As Roberto mentioned, reserve adequacy is the outmost important aspect for our central bank. Most emerging markets' central banks reserves, as shown in Figure 2, are above the IMF reserve adequacy ratio, and we think that this cushion or this buffer provides some flexibility in your reserve management, by employing some kind of tranching.

Figure 2. Hungary's reserves are adequate

Hungary's reserves are adequate based on IMF metrics

- Most EM central bank reserves are above the IMF reserve adequacy ratio.

- The additional buffer provides some flexibility in reserve management.

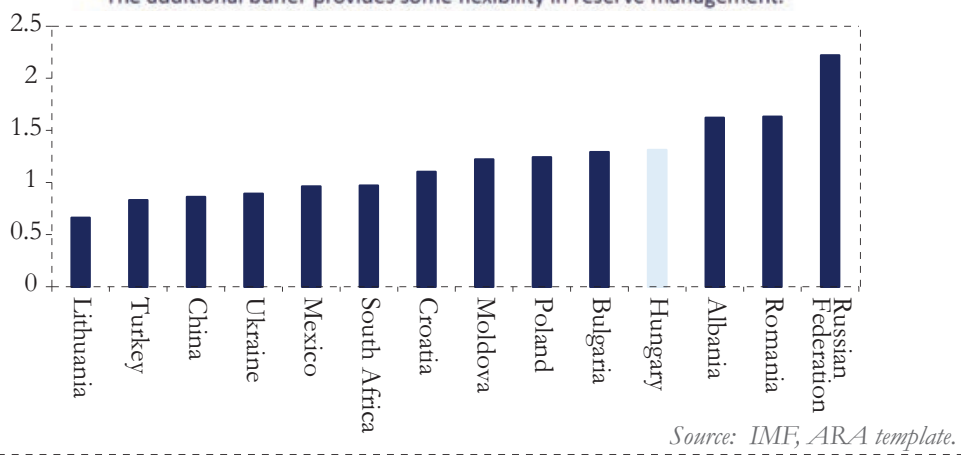




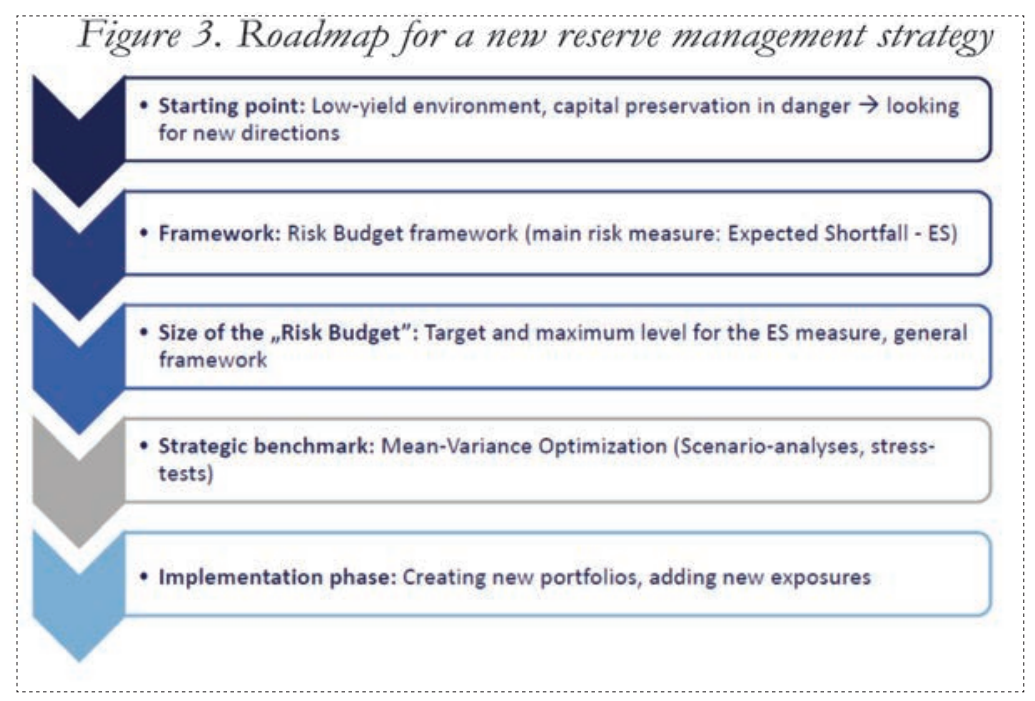

Figure 3 shows the Hungarian central bank roadmap for a new reserve management strategy in response to the negative yield environment. The end-product is a new strategic benchmark. I have already touched upon the background and the motivations to create that benchmark. In the meantime, we created a new framework because we felt the need to have a new limit system to manage and control the overall risk of the whole reserves. We calculated, then, the appropriate level for that limit and, in the next step, we created the new strategic benchmark with mean-variance-optimization. The implementation phase is still under way.

\section{ASSESSMENT CRITERIA FOR NEW INVESTMENT OPPORTUNITIES}

Traditionally, when you are considering new investments, you have to assess how each new investment will impact your risk profile. For us, the return objective is to try to avoid or minimize the capital loss; from the risk perspective, the maximum tolerable/acceptable risk level should be based on macroeconomic and institution-specific factors; and if you believe in efficient financial markets, then you also believe that there is "no free lunch" on the market. Therefore if, 
you want to increase your expected return, then you have to increase your risk level also. So that is why we felt the need to have a new framework.

\section{RISK BUDGET FRAMEWORK}

What is this framework? This framework is some kind of variation of the risk budget, and it is important to know that this additional overall limit will not replace the traditional limit system already in place, but they will work side by side, and hopefully the combined effect will be conscious and controlled risk-taking.

In practice, the risk budget is a numerical value. We have chosen the expected shortfall as a risk measurer with 95 percent confidence on a one-year time-horizon. We will express this number in a nominal value, and that's the maximum limit that the portfolio could not breach even in market downturns. It's also important to know that previously we monitored the risk level portfolio, but we didn't try to manage it, and with this new framework, we are trying to achieve that.

\section{RISK BUDGET SIZE}

Now let's look at the factors that affect the size of the risk budget. We can divide them into four groups. The most important we have touched upon is the reserve adequacy and other institutional - specific balance sheet item factors, but we also look at the historical evolution of the risk level on the current and previous portfolios that give you a good sense of how bad things can get. Also, we performed the scenario-analyses, stressed the portfolio, and of course we surveyed the management of the central bank about their risk appetite and what their preferences were. Based on those factors, we calculated the target risk level for the strategic benchmark, then we applied a tolerance level, a tolerance range around that, and of course we calculated the maximum risk, which would be like a final base line of defense. The regular reviews are done yearly, but there are certain trigger events that would require an immediate review of the size of the budget. 


\section{THE NEW STRATEGIC BENCHMARK}

Now let's look at the most important and interesting part of the presentation, the new benchmark. The creation of the new strategic benchmark is a product of a multistage process. In the first step, we tried to identify the relevant directions and promising asset classes by examining individual risk factors. In the next few steps, we tried to filter out the outlier portfolios and tried to create a short list of portfolios that would be in the proximity of the expected shortfall target level. Then we analyzed those portfolios with additional risk measures and applied different kinds of stress tests. In the final step, the management made the choice of the strategic benchmark based on their personal preferences.

Figure 4. Position of individual risk factors in the risk-return profile determines the relevant directions

\section{Position of the individual risk factors in the risk-return} profile determines the relevant directions

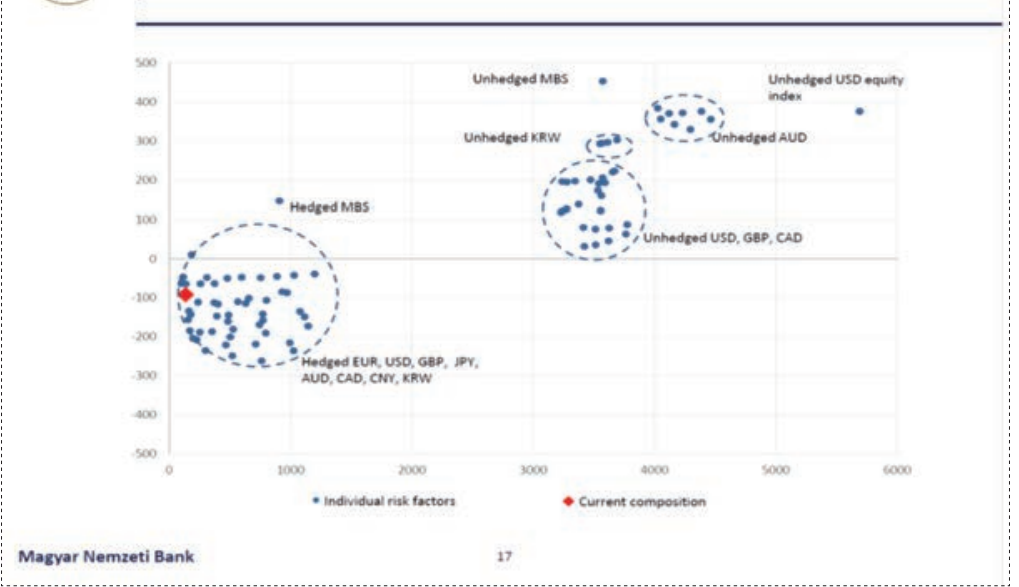

This was basically done by looking at the different asset classes on a hedged or unhedged basis in the risk-return space. This analysis functions as a kind of knockout feature, because if there is an investment category or asset that would offer just a small amount of additional returns for a huge increase in the risk level, then you should probably cross out that investment category from your list. 
The three areas that we identified are displayed in Figure 4. I have to mention that when we were thinking about the new investment opportunities, we told ourselves: make only those investments that you would do under normal circumstances and in a normal yield environment rather than in this negative yield environment, because we want to be on the safe side of things, as Roberto mentioned.

So, the first area is the geographical diversification: entering a new market; the second one is taking open currency positions because right now the whole benchmark is hedged to euro; and the third is the asset allocation, for example, increasing "MBS" exposure or creating equity portfolios.

Related to the geographical diversification, we created a scoring system, and tried to rank the countries based on the fundamentals, sovereign credit rating, market size/depth liquidity, etc. And as you can see from Figure 5, Australian and Canadian markets topped the ranking.

\begin{tabular}{|c|c|c|c|c|c|c|c|c|c|c|c|c|c|}
\hline \multicolumn{14}{|c|}{$\begin{array}{l}\text { Figure 5. Geographical diversification, internal scoring } \\
\text { Geographical diversification }\end{array}$} \\
\hline \multicolumn{14}{|c|}{$\begin{array}{l}\text { - Ranking is based on a scoring system (fundamentals, sovereign credit } \\
\text { rating, market size/depth-liquidity, etc.). } \\
\text { - AUD and CAD topped the ranking. }\end{array}$} \\
\hline Gimeria & $A U D$ & $C A D$ & KaW & NOK & SER & N2D & OKK & ㅇf & SOD & EUR & 150 & JPY & GBP \\
\hline Crestination & 1 & 1 & 0.5 & 1 & 1 & 0.5 & 1 & 1 & 0 & 1 & 1 & 0 & 0.5 \\
\hline Fundumentals & 0.8 & 0,7 & 1 & 09 & 0.7 & 0.7 & 0.8 & 05 & 0.5 & 0,7 & 0.5 & 0.3 & 0.5 \\
\hline 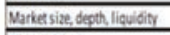 & 1 & 1 & 0,4 & \begin{tabular}{|c|}
09 \\
\end{tabular} & 09 & 0.1 & 0.8 & 09 & 0.1 & 1 & $\frac{1}{1}$ & 1 & 1 \\
\hline Gices tetern & 0.5 & 0.5 & 1 & 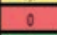 & 0 & 0 & 0 & $a^{2}$ & 0 & 0 & 0,7 & 0,9 & 0.5 \\
\hline Financial meriestability & 1 & 1 & 0.5 & 1 & 1 & $\frac{1}{1}$ & 1 & \begin{tabular}{|l|l|}
05 \\
\end{tabular} & 1 & 0.5 & $\frac{1}{1}$ & 1 & 1 \\
\hline interastonal prectise & 1 & 1 & 0 & 0.25 & 0.25 & 0 & 0 & 0.25 & 0 & 1 & $\frac{1}{1}$ & 1 & 1 \\
\hline Diversification & 1 & 0.5 & 1 & 0 & 0 & 1 & 0 & 0 & 1 & $\begin{array}{l}0 \\
\end{array}$ & 0.5 & 1 & 0 \\
\hline $\sin$ & 6.3 & 5,7 & 44 & 40 & 3.8 & 3.3 & 35 & \begin{tabular}{|l|}
3.1 \\
\end{tabular} & 27 & \begin{tabular}{|l|}
42 \\
\end{tabular} & 5,7 & 5,2 & 5.0 \\
\hline
\end{tabular}

We were glad to see that other central banks think about the new markets in the same way. Figure 6 is a glance from a HSBC reserve management survey that shows that other central banks favor the Australian and Canadian markets as well. 
Figure 6. Geographical diversification and HSBC survey

\section{Geographical diversification}

\section{Our internal scoring result is in line with the views of other central} banks.

Number of central banks investing in non-traditional reserve currencies

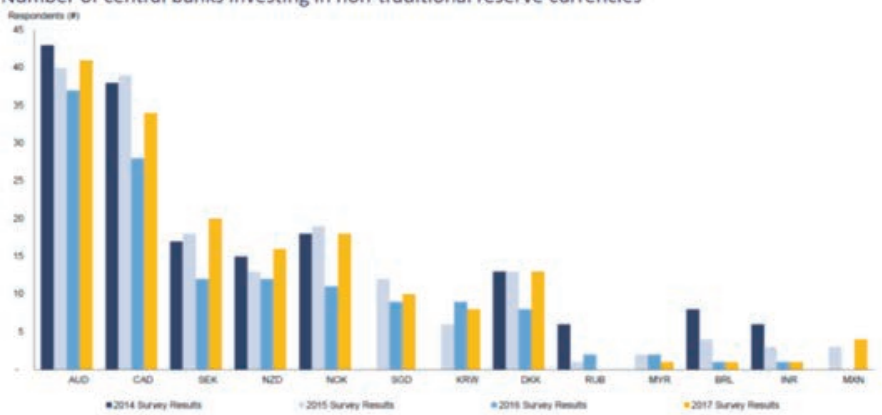

Source: HSBC Reserve Management Trends 2017. Magyar Nemreti Bank.

Figure 7. "Treasury", curves

Open currency position: most treasury curves are flat

Steep yield curves: AUD and USD $\rightarrow$ providing some carry if positions are not currency hedged.

Government bond yield curves

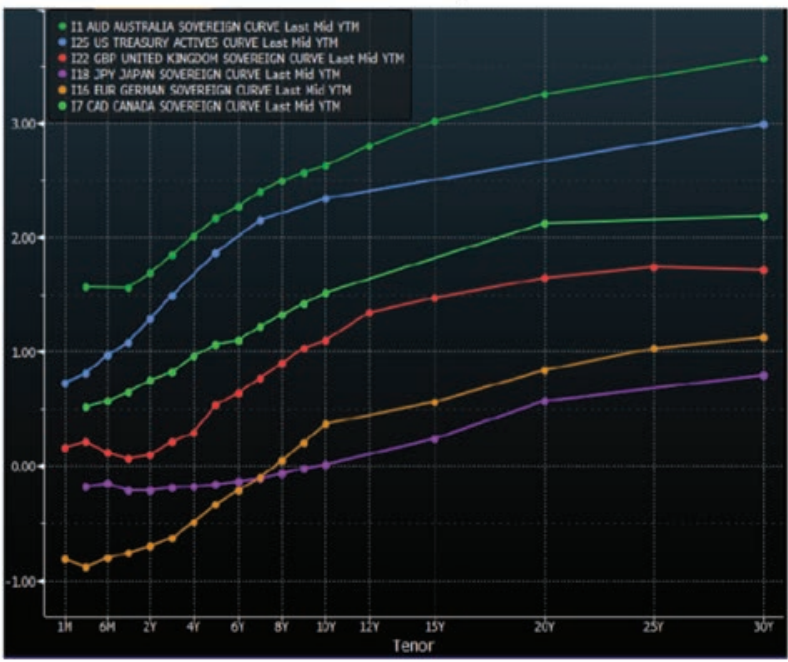

Source: Bloomberg. Magyar Nemzeti Bank. 
Regarding the open currency position, most treasury curves are flat, so only a few markets offer carry potential, namely the Australian dollar and the US dollar.

As I mentioned, you can consider increasing your exposure to MBS. The agency MBS market is one of the largest US bond sectors, after Treasuries and corporates. It is a homogeneous bond market with deep market liquidity, and with a strong state commitment, as evidenced by Figure 8 .

Figure 8. Agency MBS market

\section{Asset allocation: Agency MBS}

- Third largest US bond sector after Treasuries and corporates ( $\$ 5.8 \mathrm{tn}$ of the $\$ 45$ tn US bond market)

- Homogeneous bond market with deep liquidity

- Strong state commitment
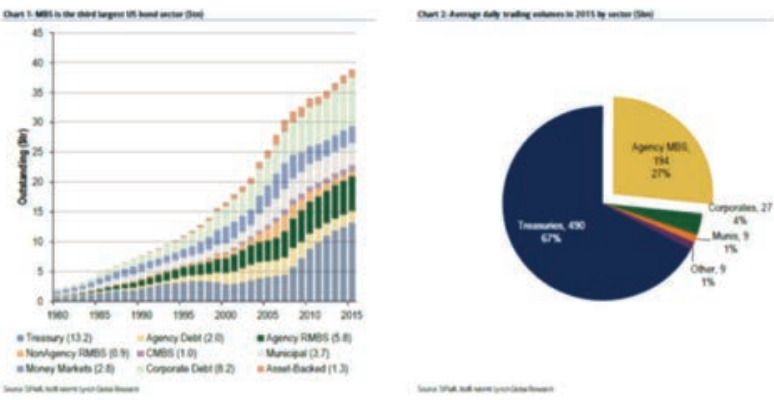

Magyar Nemzeti Bank.

And this commitment is translated into the highest achievable credit rating, and it also offers favorable risk adjusted return, spread over Treasuries, as evidenced by Figure 9 . 
Figure 9. Agency MBS market, long-term performance

\section{Asset allocation: Agency MBS}

- High credit quality: AAA rating with the implicit or explicit guarantee of the US government

- Favorable risk adjusted return, spread over Treasuries

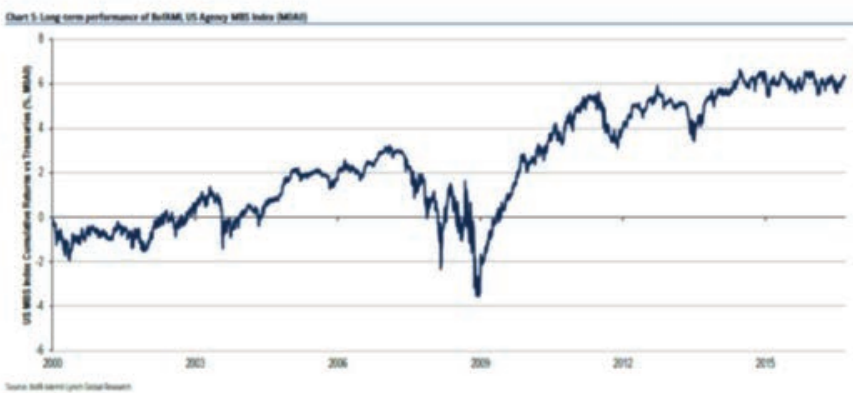

Magyar Nemzeti Bank.

Figure 10. Equity

\section{Asset allocation: Equity}

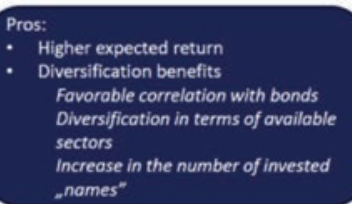

Cons:

Higher volatility

Increasing correlation in times of market stress

Headlline risk, communication challenges

Additional considerations

- Use of derivatives

- Communication

- Timing

- Need for external manager(s)

Benchmark, sector selection

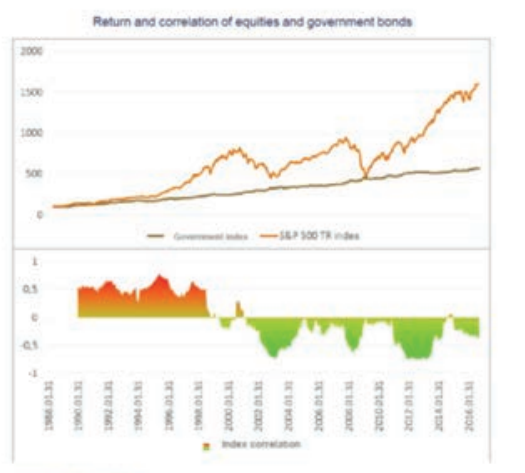

Source: Bloomberg

Magyar Nemzeti Bank. 


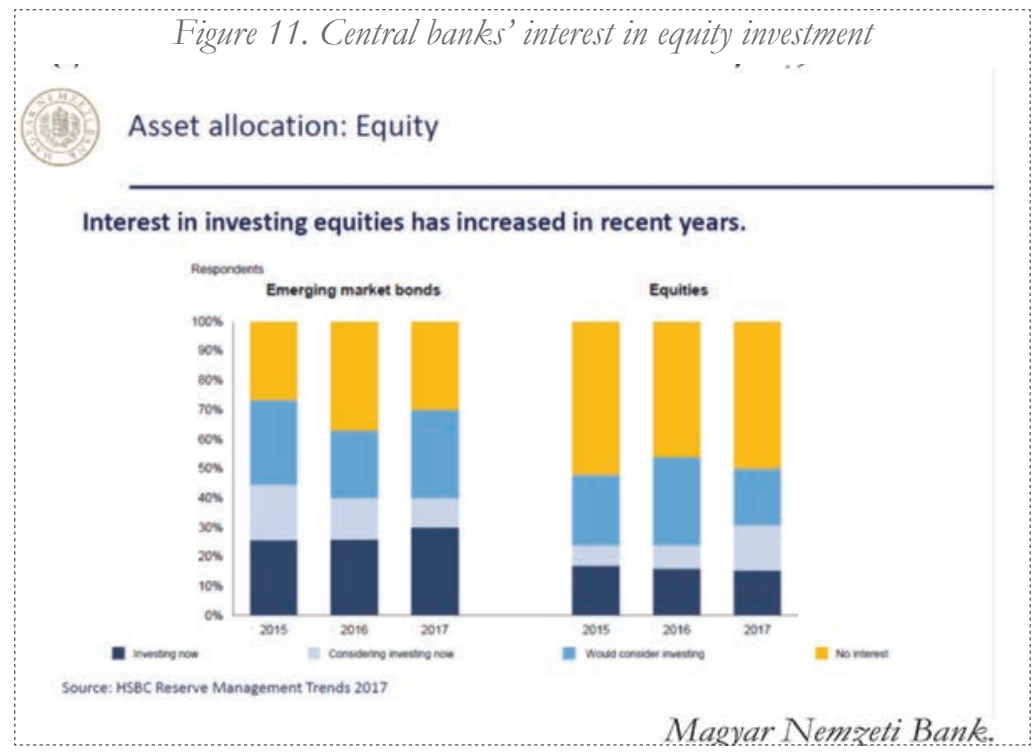

When you think about equities, you face several pros and cons. On the upper graph of Figure 10, you can see that by entering the equity market, you can increase your expected return with the inclusion of equities. They also provide diversification benefits through the number of issuers that you can invest in, and they have a favourable correlation with bonds.

On the other hand, you have to face a higher volatility in the shortrun. The correlation tends to increase in times of market stress, when you need the diversification benefits the most. Also, you have to face serious headline and reputational risks if you decide to invest in equities.

Figure 11 is from an HSBC survey. On the right side you can see that about 10 percent of the central banks already invest in equities and 40 percent currently considers or would consider investing in equities. We can see that almost half of the central banks are interested in the equity market.

Our proposed new strategic benchmark would entail a 15 percent shift in the strategic asset allocation. The most important is that it would decrease the euro exposure and increase the US exposure. 
Looking at the risk-return profile again, as displayed by Figure 13, we are trying to move up to the right, and hopefully, this will improve the return on the reserves.

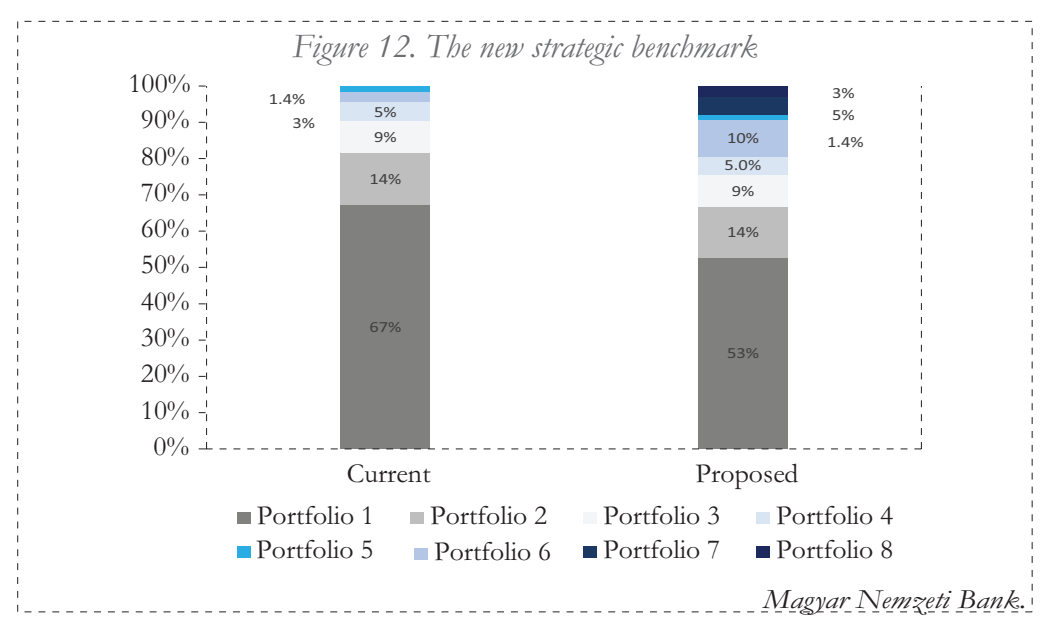

Figure 13. Risk-return profile of the new strategic benchmark The new strategic benchmark offers a significant improvement in the risk-return profile

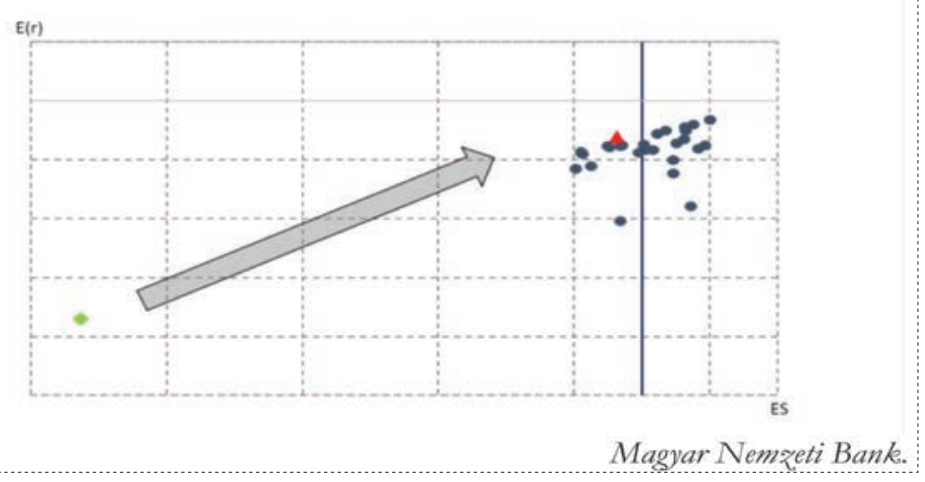


This page intentionally left blank 
This page intentionally left blank 


\section{FOURTH SESSION: NEGATIVE EURO AREA INTEREST RATES AND RESERVE MANAGEMENT (CONTINUED)}

Moderator: Roberto de Beaufort Camargo World Bank, Lead Financial Officer 
This page intentionally left blank 


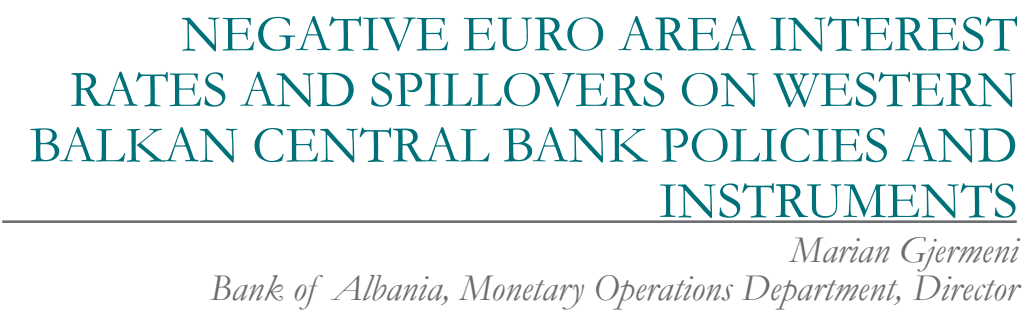

1. RESERVE MANAGEMENT CHALLENGE: STABILITY VS. RETURN

When we were discussing about the outline of the presentation on reserve management from the perspective of the central bank, we thought that it would have been more appropriate to focus on the trade-off between the objective of the stability of the country from one side and the challenge of the returns from the reserves portfolio, on the other side. The returns are considered necessary to ensure the central bank's independence from the Ministry of Finance, in terms of having enough revenues to cover the bank's expenses. With this concept in mind, we finalized the outline of the presentation as it follows: firstly, we give a general framework of the reserve management; afterwards, we present the tranching structure, the currency composition, the risk exposure, our future plans, and some conclusions that we derive from our recent experience in the management of the reserves portfolio.

\section{RESERVE MANAGEMENT}

I will start quoting the IMF Guideline for Foreign Exchange Reserve Management, with which we comply. The guideline defines reserve management as "the process that ensures that adequate official public sector foreign assets are readily available to and controlled by the authorities for meeting a defined range of objectives for a country or union." The main idea behind this concept is that we need to be certain/clear that the reserve management, from the point of view of the central bank/public institutions, is different from reserve management at private institutions. 


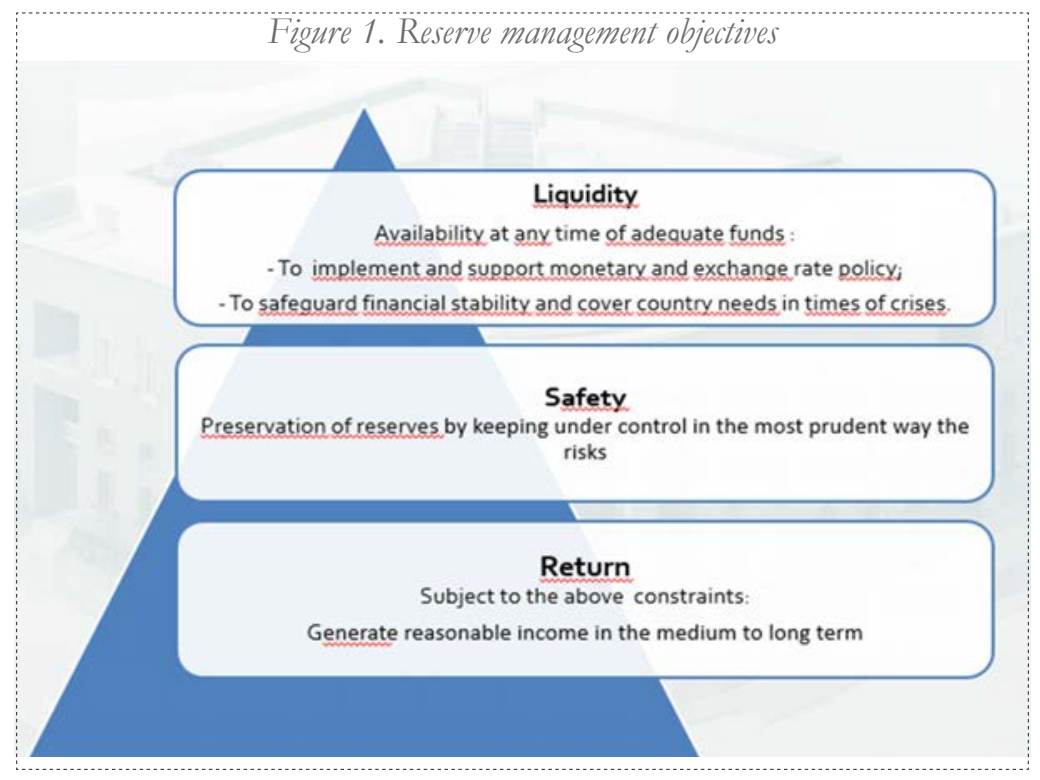

As a matter of fact, our main objective is to have adequate official public sector reserves that can be ready and available at any time that they are needed. In fulfilling our purpose, we have also established the priorities that should guide our reserve management. They are shown in Figure 1. The first priority is liquidity. When we say liquidity, we mean that we need to have available funds for two main reasons. The first reason is to implement the monetary policy of the central bank and, the second one, to safeguard financial stability and to cover any needs Albania might have, should the circumstances require it.

The second priority is to preserve the capital. This priority shapes the reserve optimization process. In this regard, we take into consideration a set of risks that I am going to elaborate in greater detail later in my presentation.

The third priority is to generate reasonable returns in the medium to long term. Nevertheless, this objective is subordinated to fulfillment of the primary objectives, namely liquidity and safety. 


\section{PORTFOLIO INVESTMENT FROM A CENTRAL BANK PERSPECTIVE}

When we turn at the difference between portfolio management from a central bank's perspective vis-à-vis portfolio management from a private investor's perspective, the main difference is the objective of holding reserves. In our case, the main objective is to have enough liquidity for fulfilling the needs that may come at any time.

Regarding risk tolerance, our risk tolerance is typically low or conservative and it is defined by the Supervisory Board.

One of the main obstacles that we have had so far is the investment horizon that, in our case, is up to one year. From previous presentations, I learned that the National Bank of Hungary is allowed to invest in equity and corporate debt. But, if we take into consideration our law, we are not allowed to invest in equity and corporates, but only in government securities. So, this is another obstacle, which limits our strategy in terms of diversification of the reserves portfolio.

And last, but not least, is the reputational risk the central bank is facing in the reserves management process. In this regard, what I am referring to, it is the transparency of the reserve management process; how this reserve management process is understood from the public and from the parliament and how the public and the parliament will react if the results of reserve management, the return of the reserve portfolio, are negative. Certainly more education, communication, and transparency are needed to mitigate this risk.

\section{REVIEW OF THE FX RESERVES POLICY AND HOLDING PURPOSES}

During 2016, we revised our regulation "On the policy and management of foreign exchange reserves." The main reason for the review was to redefine the purpose of holding reserves. In the previous regulation, our only purpose was the implementation of monetary policy, but, now, we have also added the purpose related to the stability of the 
banking system. The latter was also taken into consideration when we built the reserve adequacy optimization model.

We looked into the currency composition of each tranche and decided to move the government's obligations, in terms of the size and the currency composition, from the liquidity tranche only to the liability tranche to avoid accounting for it twice.

Moreover, we decided to take into consideration the negative return that we can have on our euro investments in terms of risk budget. Hence, our expected return is negative from the beginning of the process and we wanted to take this into account.

Pursuant to this revision, the regulation now stipulates that Bank of Albania reserves' holding purposes are: (1) to implement and support the monetary policy and exchange rate policy; and (2) to safeguard financial stability or cover the country's needs in times of crisis.

\section{GOVERNANCE FRAMEWORK}

Regarding the governance framework, I think it is more or less similar to all central banks. The Supervisory Board sets qualitative criteria on the strategic objectives of the central bank and risk constraints.

We have the Investment Committee that translates these qualitative criteria into quantitative limits and also defines the benchmarks that are used for the implementation of investment decisions.

Then, we have the operational monitoring framework that is compliant with all the limits that are approved by the Investment Committee and the Supervisory Board. 
Figure 2. Bank of Albania foreign exchange reserves' stocks

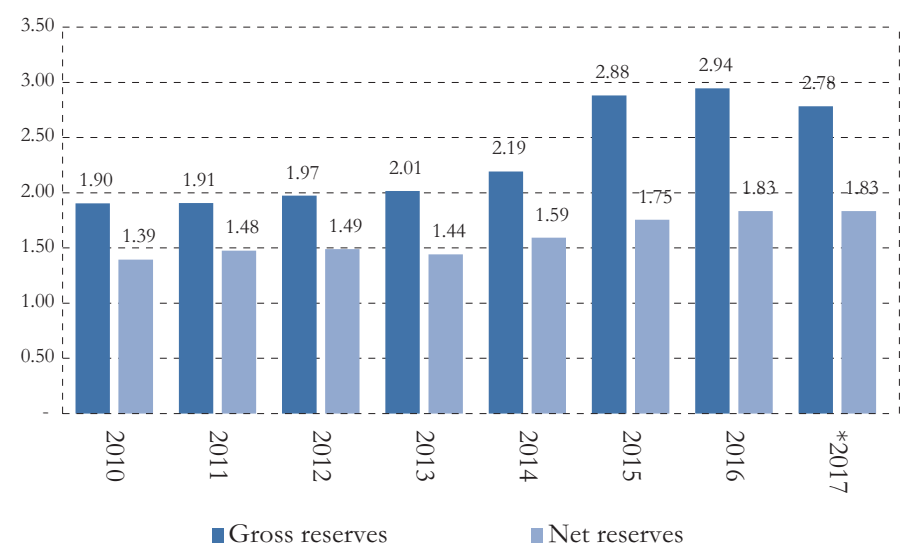

\section{RESERVES' STOCK}

Figure 2 shows the trend of the reserves of the central bank, and I purposely put it on a gross basis and on a net basis. In terms of gross figures, we have an increase of the reserves, which mainly is due to the extra funds that are coming from the Ministry of Finance and the

banking system. But, on a net basis, we have more or less a stability in the level of our reserves. This leads us not to make big changes in the risk profile of how we manage the reserves. So, net reserves that are managed by the central bank have been stable starting from 2015. Being stable, the utility function of holding reserves for this part of the reserves remains almost the same. 


\section{ELIGIBLE INSTRUMENTS}

\section{Figure 3}

\section{Where is the market?}

- Buying negative yield - pay for insurance protection

- Implies negative expected returns for different investment horizons

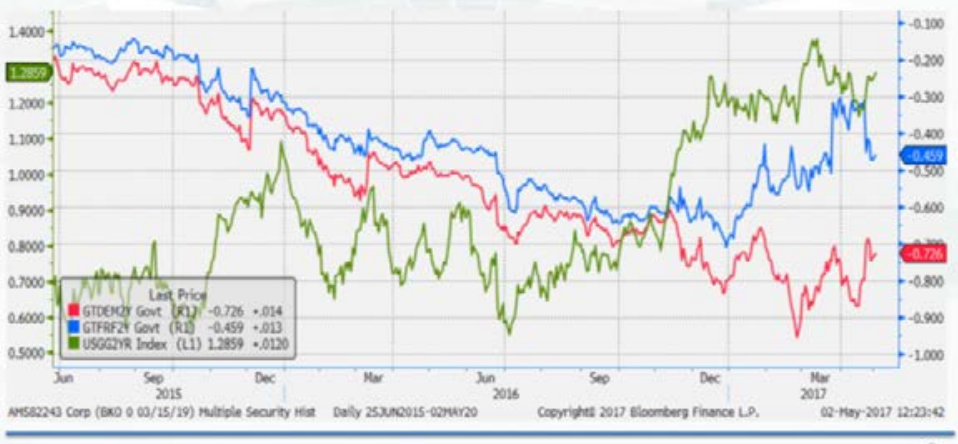

Now the other question is, "Where can we invest these reserves?" Due to our policy regarding the currency composition of the reserves, we are forced to hold the major part of the reserves in euro. Taking into consideration market conditions (for example, investing in Germany and France), we are obliged to invest this part of the reserves in negative territory.

On the other side, in Figure 3, we have the green-colored line that reflects the behavior of the yield of the two-year US dollars Treasury Note, which is in positive territory. The negative impact of the euro portion of the reserves was more than offset by the dollar portion of the reserves.

With these two factors in mind, the level of the reserves and the investment alternatives, we start internally the reserve management optimization/implementation process. We start with the first requirement that we have defined above: the management of the liquidity risk. 


\section{RESERVE MANAGEMENT TRANCHING}

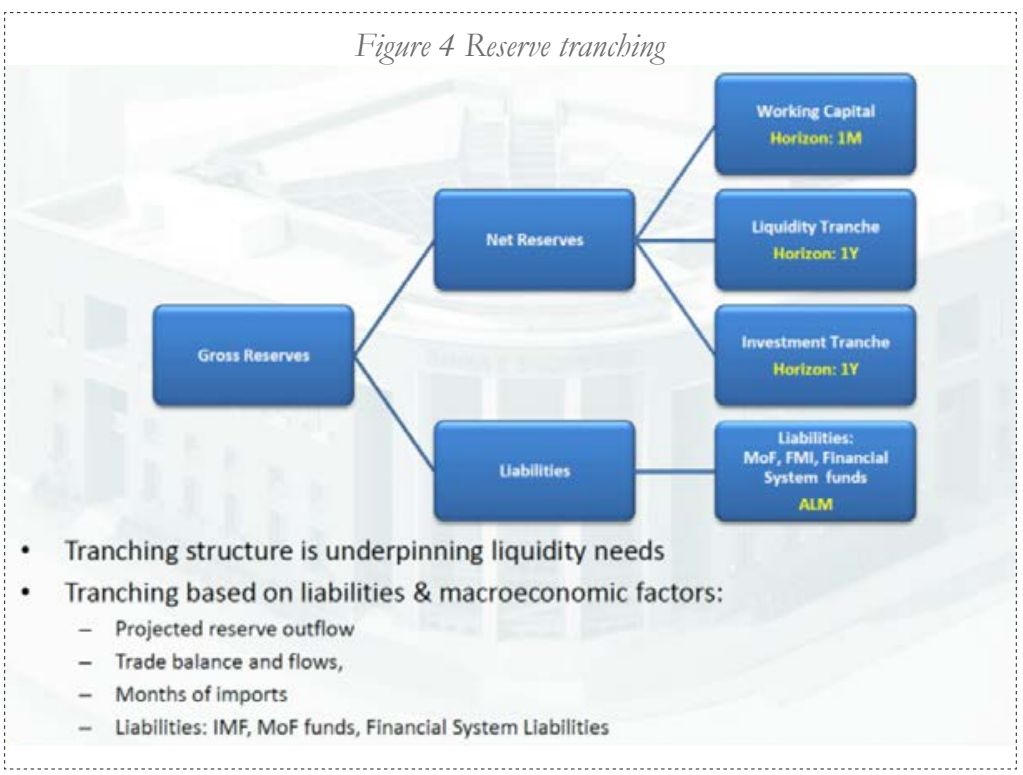

To manage the liquidity risk, we divide the reserves in different tranches as shown in Figure 4.

The liability tranche represents the portion of reserves that do not belong to the central bank. However, the central bank is responsible for its management.

The net reserves are divided into three tranches: the working capital tranche, the liquidity tranche, and the investment tranche. Except for the working capital tranche, which has an investment horizon of just one month, the other two tranches have an investment horizon of one year. Even for the liability tranche, we decided to maintain an investment horizon of one year to fit it in some way with the risk budget that we have as allowance in taking position/exposure to interest rate movements.

When we implement the tranching structure, we take into consideration factors like: (1) what will be the cash flows of the central bank and the Ministry of Finance for the coming year, (2) trade balance, and (3) the amount of imports that we need to cover when and if needed. 
More specifically, the liability tranche does include everything that is related to the Ministry of Finance, reserve requirements of the banking system, and other liabilities of the central bank. The working capital tranche is covering any need the central bank might have in the event of market interventions and the monthly current account deficit. For the liquidity tranche, we have an investment horizon of one year and the upper limit is the amount of three months of imports. Finally, the investment tranche includes everything in excess of the liquidity tranche. In the investment tranche, we have the flexibility to take more risk in terms of duration.

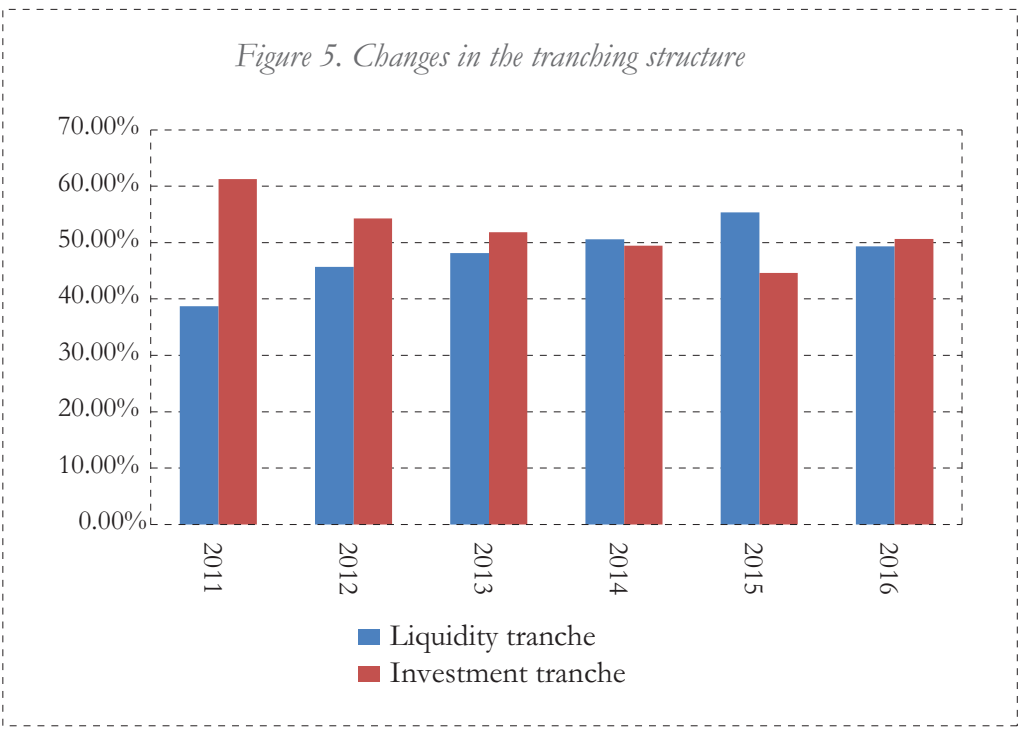

In Figure 5, the trend of the investment tranche is shown by the red bars and the trend of the liquidity tranche is shown by the blue bars.

Up to 2015, the size of the investment tranche was declining, whereas the size of the liquidity tranche was going up. This reflected the maturity of a Ministry of Finance's Eurobond in 2015. We, as the central bank, took precautionary measures in advance of this payment. But, after that, we realized that the way we had managed this contingent event was not the right one. We decided that similar future events need to be managed with appropriate instruments 
(repo transaction). That is, if the Ministry of Finance needs to pay its debt, and it has no liquidity, we can repo out our securities to get liquidity from the international market and lend the necessary amount to the Ministry of Finance.

By doing this, we avoid many exchange rate transactions and the movements of funds from the investment tranche to liquidity tranche, and thereby avoid unnecessary exchange rate risk (currency composition of two tranches isn't the same).

And, as we can see from Figure 5, during 2016, the trend has reversed. This is the reason the investment tranche is higher than the liquidity tranche.

\section{RESERVE MANAGEMENT CURRENCIES}

Regarding the currency composition, we keep our reserves in six currencies. Euro and US dollars are the most important ones. GBP, JPY, RMB, and AUD are the other currencies composing the reserves and are included only in the investment tranche. The inclusion of AUD and the SDR in the currency composition for the investment tranche is, among others, the result of the diversification strategies implemented by the Bank.

More than 50 percent of reserves are in euro. This reflects mainly the liability side of our balance sheet. The Ministry of Finance increased the holdings/deposit of its foreign currency at the central bank with the purpose of having more buffers to reduce the rollover risk. At the same time, we have the commercial banks that have increased their EUR holdings with us. Such increase reflects not only mandatory reserves in foreign currency but also the excess reserves held by the banking system in excess of the mandatory reserves.

The currency composition of the liquidity tranche, after the changes we made, is based only on the imports of Albania (80 percent of our imports are in euro and around 20 percent are in US dollars). As a result, due to these two factors, we are obliged to have more euro in our reserves compared to other currencies. 
Given the above-mentioned criteria, we are not active on the currency exposure. This means that the Investment Committee approves the limits in compliance with the criteria, and we manage only the discrepancy between the actual exposure and the benchmark for the composition of the foreign currency reserves.

\section{CURRENCY DIVERSIFICATION}

During 2016, as a result of the RMB inclusion in the SDR basket, we decided to take exposure not only in RMB but also in Australian dollars. The exposure in RMB is much lower than its weight in the SDR basket. This decision reflects our uncertainties regarding market transparency and market functioning in China. To make up for the reduced exposure of the RMB in the SDR basket, we decided to introduce AUD as an emerging market representative. With time, we shall evaluate whether it is appropriate to increase the exposure of RMB and reduce the exposure of the Australian dollar to fully reflect/match the SDR basket currency composition.

Figure 6. Trend in currency composition

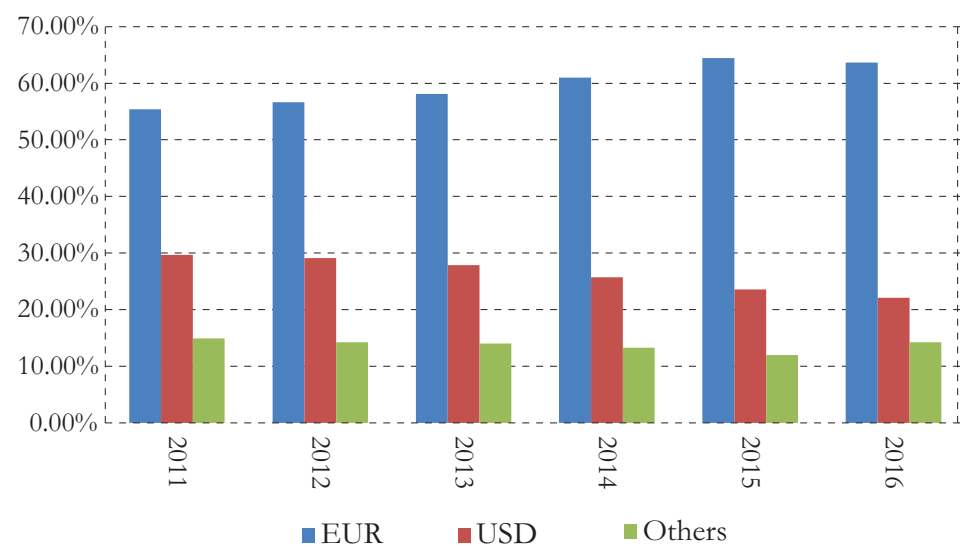

As you can see from Figure 6, the percentage of euro in our total reserves is going up from 55 percent to 63 percent. As previously 
mentioned, the underlying reason for this trend is the euro mandatory reserve requirements and excess reserves held by commercial banks as well as the euro buffer on the Ministry of Finance account.

In order to minimize the negative impact of this trend in our profit and loss account, we took some steps. The first step was in 2016, when we decided to negatively remunerate the euro reserve requirement of the banking system, by setting the remuneration rate equal to the rate of the deposit facility of the European Central Bank, that is, -40 basis points. The second step was related to the remuneration rate applied to excess reserves, and we decided to remunerate them at a rate equal to the ECB deposit facility rate minus 25 basis points (this is more or less the market rate of the euro currency in the short term). As related to the euro holdings of the Ministry of Finance, we decided to swap the foreign currency in Albanian lek. In pricing the swap, we took into consideration the cost of holding euro in the cash account with our counterparties.

\section{RESERVE MANAGEMENT - INTEREST RATE}

What I have discussed so far were the liquidity risk and the exchange rate risk. The next step is managing the interest rate risk. This is done through an optimization exercise incorporated in the strategic asset allocation process. The main objective is to maximize returns in one-year investment horizon. Our risk constraint is stated at VaR 99 percent. It means that we need to have a 99 percent confidence level of not losing more than the budget of risk that the Supervisory Board has approved.

In this case, we are active managers, meaning that each portfolio manager has its own tactical risk budget. The result from active management so far has been really impressive in terms of riskadjusted returns (sharp ratio). 


\section{MARKET RISK WITH NEGATIVE INTEREST RATES}

Regarding our reaction to the negative interest rates environment, when we discussed how we should adapt our allocation, we exploited the possibility of taking more credit risk in our benchmarks. I am referring to Italy and Spain, and the fact that we decided to include these countries in the benchmark up to a certain ratio. At the same time, we moved from a single country benchmark to a multi-country benchmark in order to be exposed not only to one country, but also to other eurozone countries.

The second step, given the negative rates, was to make adjustments in the budget of risk, especially for the euro currency, and to treat the level of negative rate as an extra in terms of risk budget. This means that the risk budget is what the Supervisory Board approved plus the negative rate. When taking this approach, our strategic assets allocation model indicated to us that the duration should be low, with the expectation that the interest rate in the euro area has more probability to go up than down. We decided to include also cash in our benchmark and to hold the cash up to the moment that we think the interest rate environment will start to normalize.

\section{RESERVE MANAGEMENT - CREDIT RISK}

\section{Figure 7}

- 2013 increasing Credit Risk appetite coupled with strengthening of internal credit risk models

- Eurozone Governments up to BBB-

- 2015 no exposure to EZ BBB- Governments in benchmark

- 2013 - 2015 positive outcome of the strategy

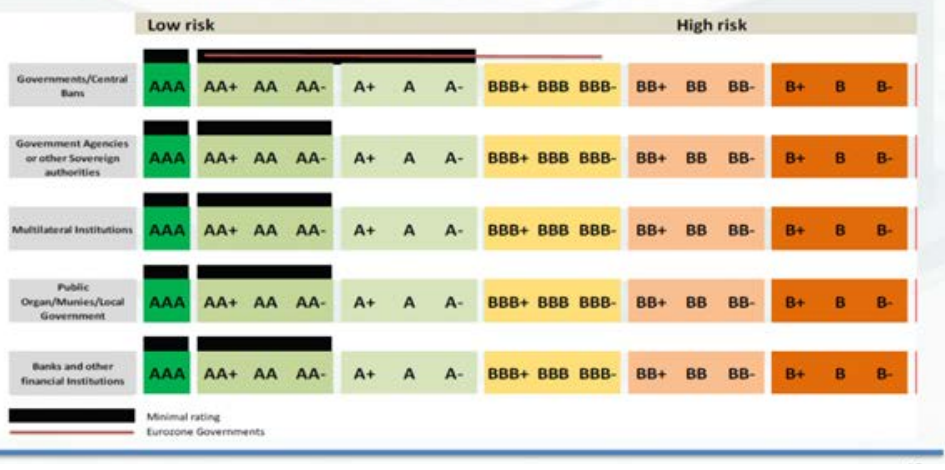


Regarding the credit risk, we increased the credit risk appetite, but, at the same time, our intention was to strengthen our internal credit risk model.

We analyzed what would be the extra value if we were more aggressive in terms of credit risk, for example, going from AA- threshold to A-. Our data analysis was showing that the pick-up from the widening of the credit risk limits was not justified in terms of risk-adjusted returns. So, we decided to maintain the same risk thresholds in our exposure to financial institutions. In the meantime, regarding government exposure, especially the governments of euro area member countries, we decided to move down the threshold, including the whole investment grade to BBB-. At the same time, we improved our credit risk models to monitor on a daily basis the situation of our portfolio exposures. So, for governments, the new threshold was BBB-, and for the rest, we remained, as we were at the beginning, at AA-

\section{RESERVE MANAGEMENT - OTHER RISKS}

We have paid special attention to the new guidelines of the IMF regarding the other risks that proved to be important during the recent crisis. Based on this, we started taking into consideration other risks, such as: custodial risk, settlement risk, and legal risk. The frameworks for these risks are going to be elaborated further by the responsible departments.

A risk that we especially need to be more alert to is legal risk. I am stating this, because probably we are not feeling it, but at the moment that we would need to have something to protect us, it may be too late.

\section{ELIGIBLE ASSET CLASSES}

On the asset classes, more or less, it is the same, but what I would like to stress here, is that due to the changes in the banking requirements from the supervisory authorities, we are facing difficulties to operate with financial institutions. Part of the problem is related to the futures clearing account. we had the option to use this facility before, but 
not now because the financial institutions are facing higher costs due to stringent/higher capital requirements. As a result, they are not inclined to work with and offer their services and products to small central banks. So, we are looking to establish facilities with other financial institutions, but it is still difficult to find the banks that are ready to cooperate and cover our needs for investing in instruments that we are ready to use for the management of the reserves portfolio.

\section{GOING FORWARD}

What we plan to do is to exploit the possibility of expanding the number of the instruments that we are eligible to use. The first one are covered bonds, the second are repurchase and reverse repurchase agreements. We would like to use the repo instrument more in respect to hedging ourselves, especially regarding the unexpected demands from the government. If we manage to implement it, we will have more possibilities to improve as well our strategic asset allocation.

So far, we implement our strategic asset allocation on a single currency basis. We are currently looking to shift the strategic asset allocation decision-making process to a tranche level. What we foresee at this stage, as result of this, is to have more diversification in the currencies, which compose the tranches. Except this, what we are thinking to do is to extend the investment horizon and to include hold-to-maturity strategies.

\section{CONCLUSIONS}

The first conclusion is that our main requirement/objective is stability and not return. As a consequence, we are obliged to hold our reserves in euro and to protect ourselves from different vulnerabilities, coming either from the banking system or due to macroeconomic factors and trade relationships.

The stringent regulatory framework causes a lot of burden in our business relationship with counterparties. This has significantly increased our maintenance costs, because it asks for a lot of information exchange and we need to spend a lot of time to fulfill 
these requirements, rather than exploiting more possibilities in terms of credit risk. Furthermore, this is a difficult time to widen the scope of collaboration with our existing counterparties. So, if we decide to include more instruments, it will be difficult to implement them given the current environment.

We trust there should be an understanding from the European Central Bank, in that it should not treat in the same way the central banks and other private investors. This is because the euro that the central banks keep in their balance sheets have different purposes compared to those of the private financial institutions. Hence, in my opinion, for the cash that the central bank is obliged to hold, the ECB can offer some facilities to cover at least the cost of negative return that we have in euro.

On the other side, the negative rates in euro have also been a contributing factor to the financial stability since the banking system has less incentive to keep euro. Moreover, the negative interest rate environment probably will contribute to de-euroization of the country and to improvements in the monetary policy transmission channels.

As a summary conclusion, I would like to stress that, in our view, from a central bank's perspective, the paramount priority should be stability, and such priority should inspire all risk/return considerations. 
This page intentionally left blank 


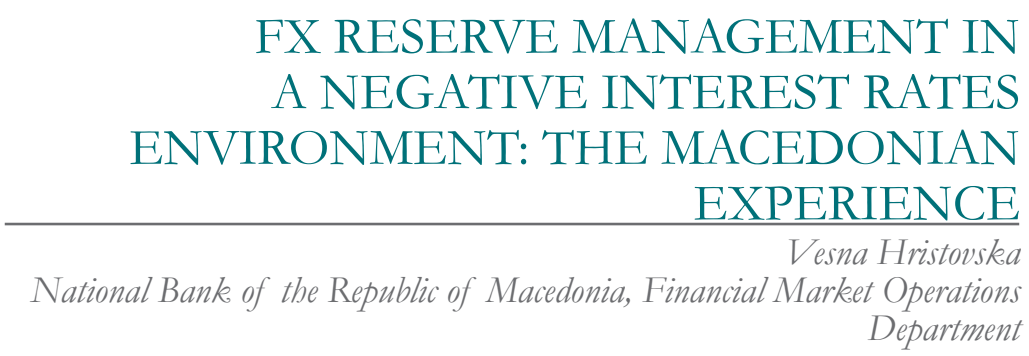

First of all, I would like to thank the organizers, the Bank of Albania, the International Monetary Fund, and the Swiss Government for giving me the opportunity to represent the National Bank of the Republic of Macedonia and our experience in coping with negative interest rates in the area of reserve management.

\section{FX RESERVE MANAGEMENT - GLOBAL TRENDS}

I would like to start talking about some global trends first. Over the past two decades, on the back of growing foreign exchange reserves, central banks have positioned themselves as influential investors in the global financial markets.

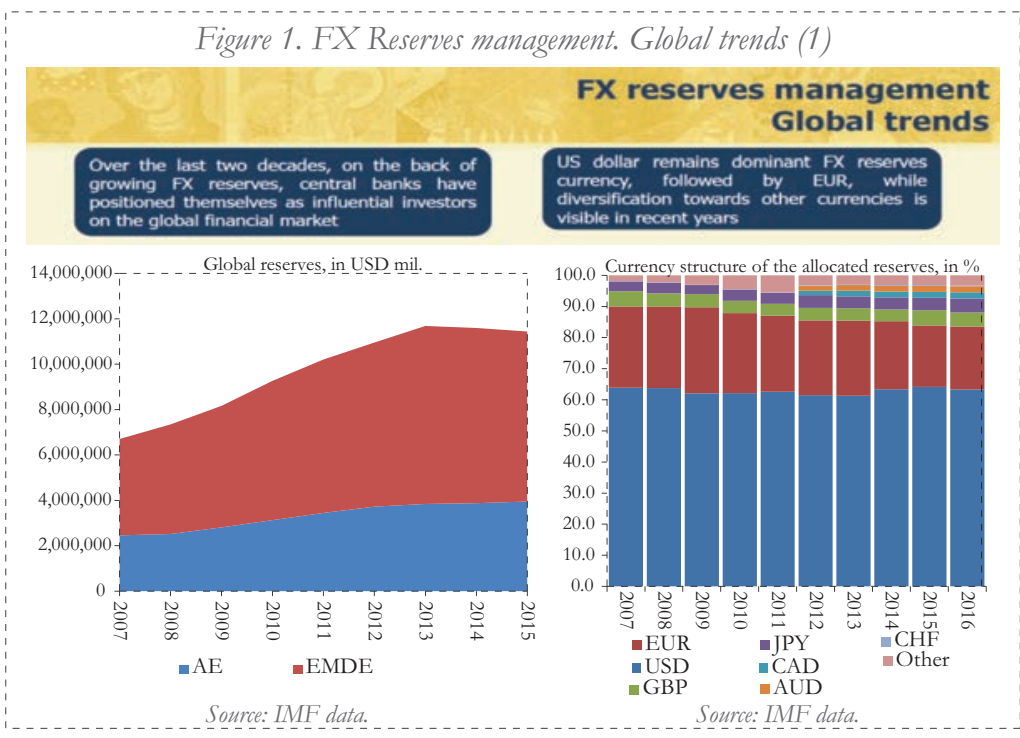


The IMF data show that the US dollar is still the dominant reserve currency of the central banks, followed by the euro. There is, however, some visible diversification in other currencies in recent years.

Some surveys of central banks' opinions show that diverging monetary policies among major central banks are still a dominant concern when managing the FX reserves, although there are other important factors such as economic development in China and in other emerging markets, and oil prices. The persistence of negative rates in some major reserve currencies has induced many central banks to introduce changes to their portfolio management, namely, in the portfolios and in the investment behavior. In terms of portfolio allocations, we are seeing reduced allocations to euro, yen, Swiss franc, extended duration, increased exposure to credit risk, and broader investments diversification in corporate bonds and equities. On the other hand, in terms of investment behavior, the aim is still to preserve the capital, which means that investors are searching for yields. There is higher risk tolerance among all the central banks as well as visible changes in the investment horizon and diversification across and within asset classes.

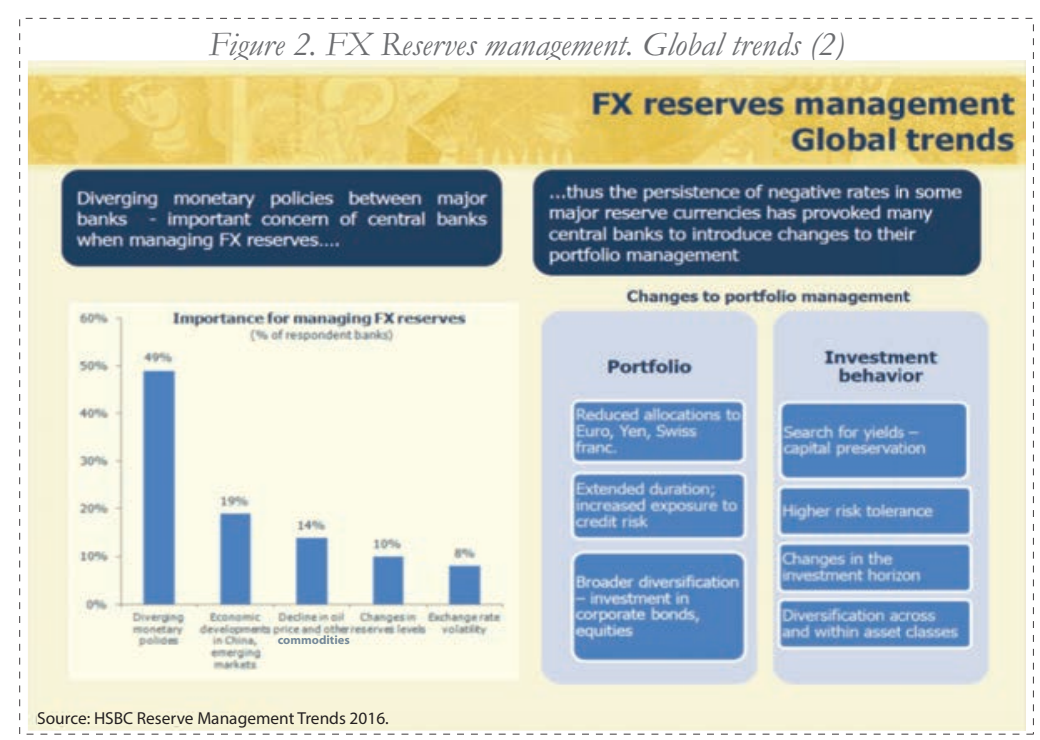




\section{FX RESERVES MANAGEMENT - THE MACEDONIAN EXPERIENCE}

I will continue with our experience. The purposes of FX reserve holdings in the National Bank of Macedonia can be divided into three groups. One is the monetary policy purpose, namely, we have been pegging our domestic currency to the euro for 20 years now, and the exchange rate of the Macedonian denar to euro has not changed. We support this by intervening in the FX market through six banks, so called market makers. The reserves are held for precautionary objectives, as they serve as buffers against balance of payment shocks. In turn, we see there is a high investor confidence in the country's ability to meet FX obligations, reduce the cost of external financing, keep the confidence in the national currency, give emergency liquidity assistance to the banking sector in case of market disruptions, and provide funding in case of a national disaster and emergencies.

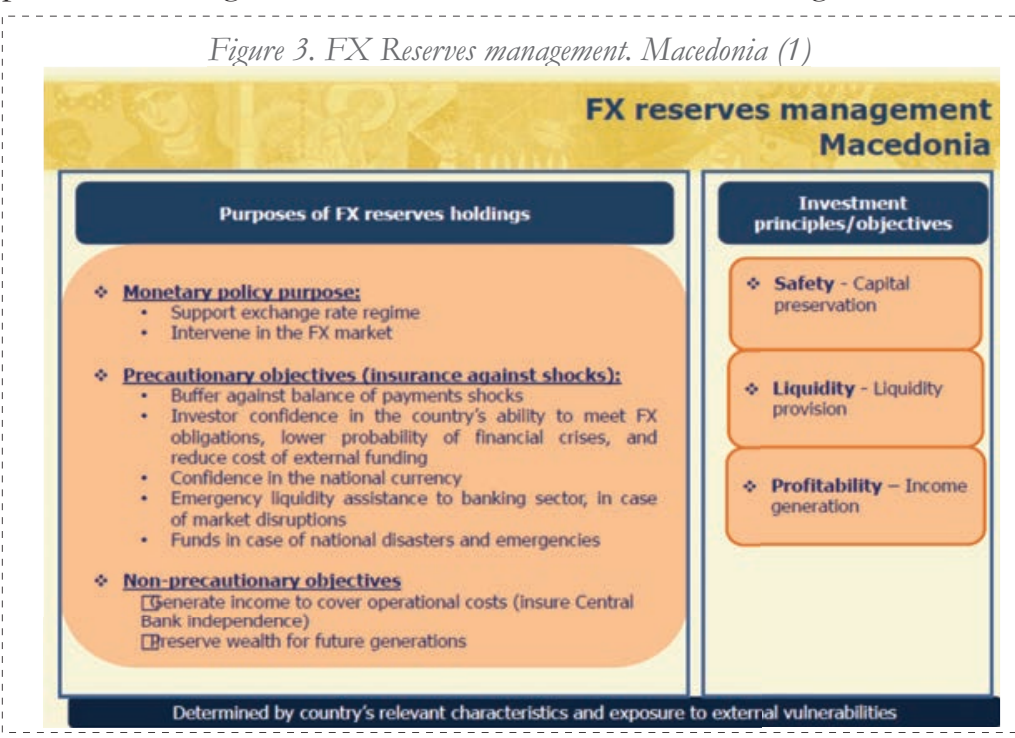

And of course, there are non-precautionary objectives, namely to generate income to cover the central bank's operational costs in order to ensure central bank independence. Almost all operational costs of the central bank, which are salaries and other costs, are covered by the profit from the FX reserves management. Another element is to preserve the wealth for the future generation. 
Moreover, we are led by the investment principles, which are: safety, liquidity, and profitability.

Our country is a small, open economy with exchange rate commitment to the euro. We have been growing steadily over the past couple of years, despite several external and internal shocks. You can see from Figure 4 that our GDP growth has been mainly above the average of the region. This has been supported by structural changes in the economy. We have encouraged foreign direct investments, and diversified the exports a lot in recent years, as shown on the right side of Figure 4. The current account deficit was also rapidly reduced from the levels recorded at the end of the last decade and has been kept at very low levels since 2010 .

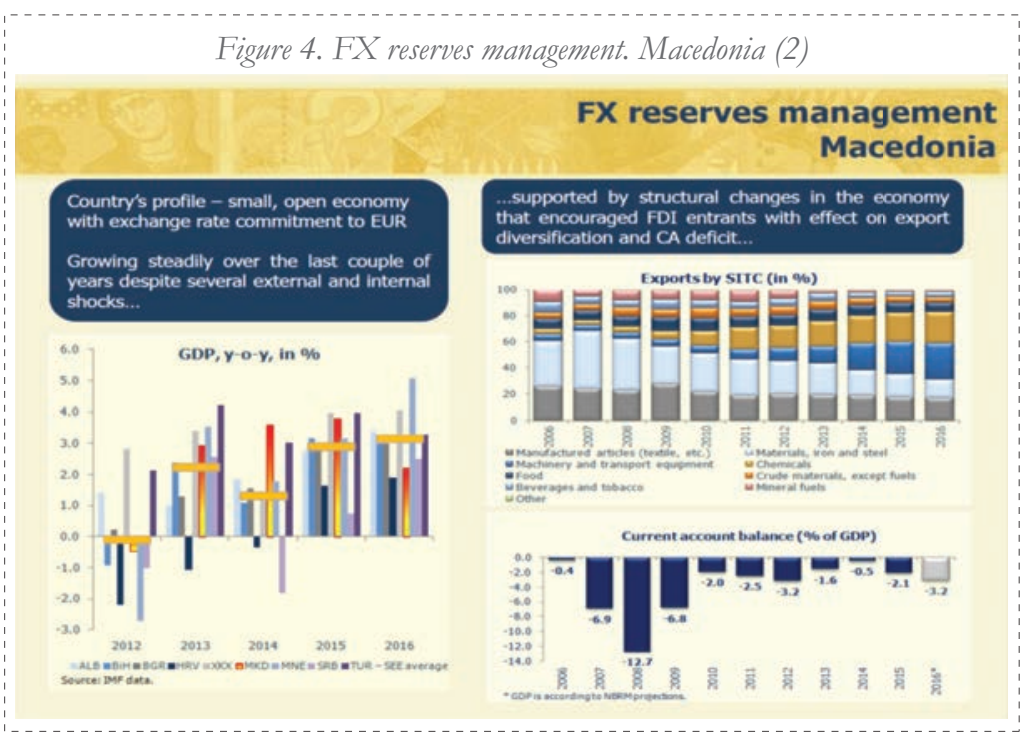

The foreign exchange reserves of the Republic of Macedonia have been generally set on a growing path and are constantly maintained at adequate levels, considering major measures for adequacy. What is the leading contributor to the reserve build-up? It is the government transactions, but we have also had foreign exchange inflows, and to protect the exchange rate, we have purchased a lot of FX in the market in recent years. 
Figure 5. FX reserves management. Macedonia (3)

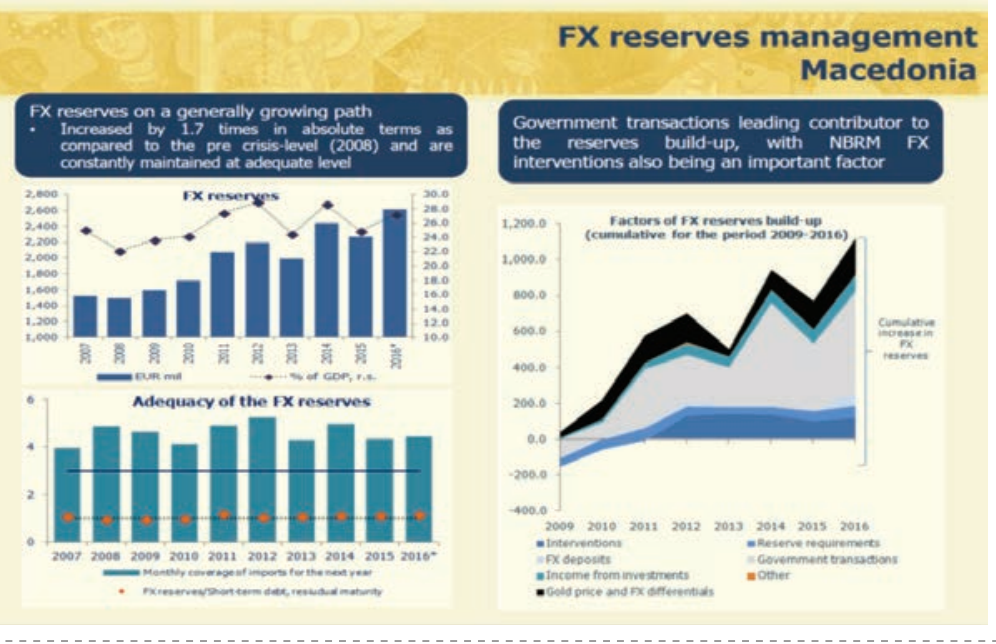

Macedonia's foreign exchange reserves as a percentage of the GDP correspond approximately to the average of the countries with similar pegged exchange rate commitments, as shown in the left-hand graph of Figure 6. They are also is in line with the average of the countries from the region, as shown in the right-hand chart of Figure 6.

Figure 6. FX reserves management. Macedonia (4)

\section{FX reserves management} Macedonia
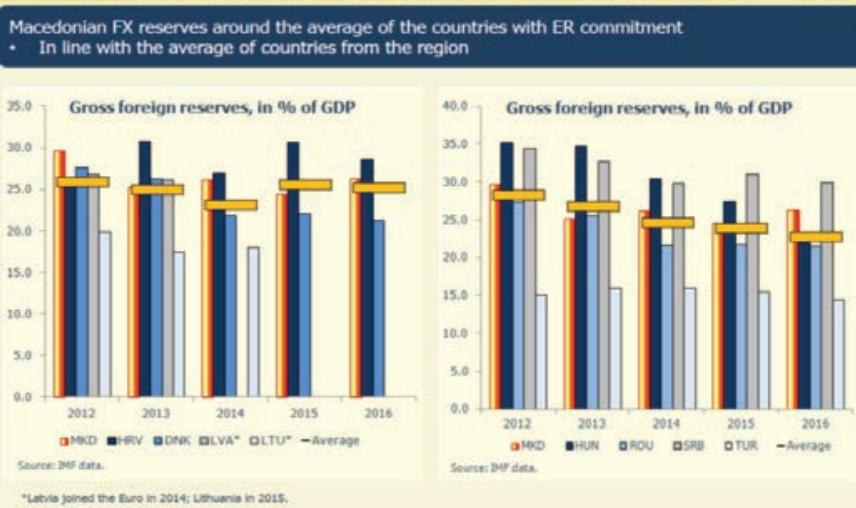
When looking at factors influencing our FX reserves currency composition and tranching, the exchange rate regime is the most important factor, because the euro is the currency of intervention. Then we look at the currency structure of trade. We export and import predominantly with the European Union. Additionally, 80 percent of our gross external debt is denominated in euro.

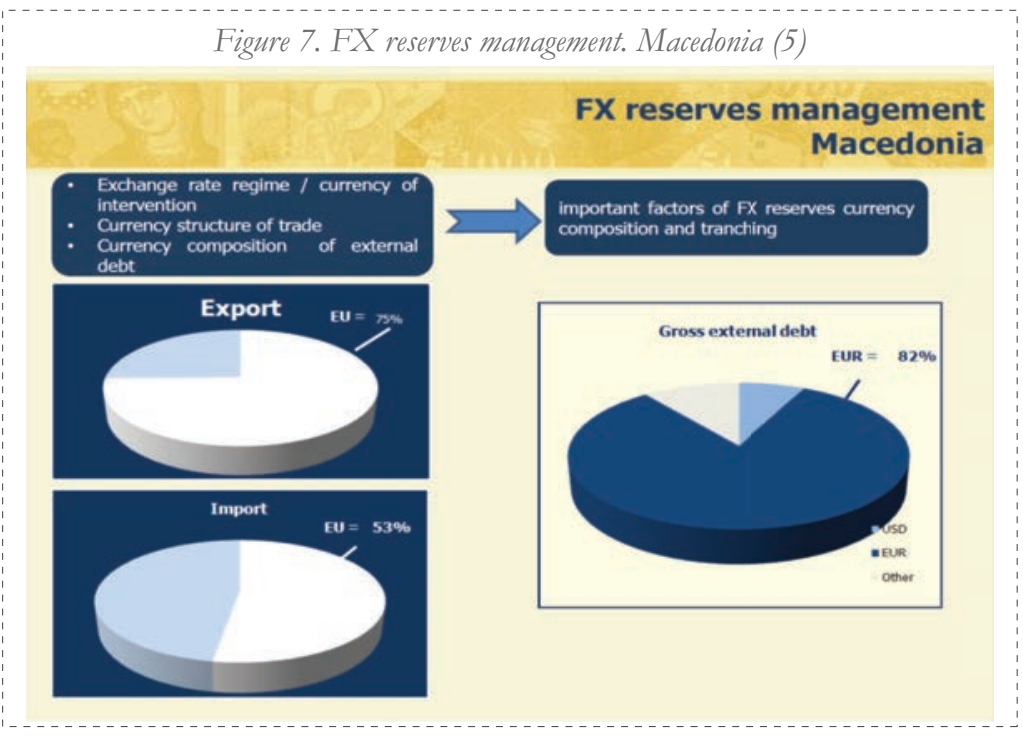

A changing investment environment and low yields for long periods have urged us to consider changes in the portfolio management strategic orientation. Namely, the markets are characterized by insufficient compensation of risk, low and negative rates, compressed spreads, diverging monetary policies, and a lot of disturbances due to political risks.

In the portfolio changes, we opted for currency diversification, extended the duration, increased credit exposure, added new instruments within asset classes, added new issuers, increased the level of the HTM (hold-to-maturity) portfolios, and increased the share of active portfolio management. Still, our investment behavior is searching for yield, and we are increasing our risk tolerance and extending the scope of eligible assets. 
Figure 8. FX reserves management. Macedonia (6)

FX reserves management Macedonia

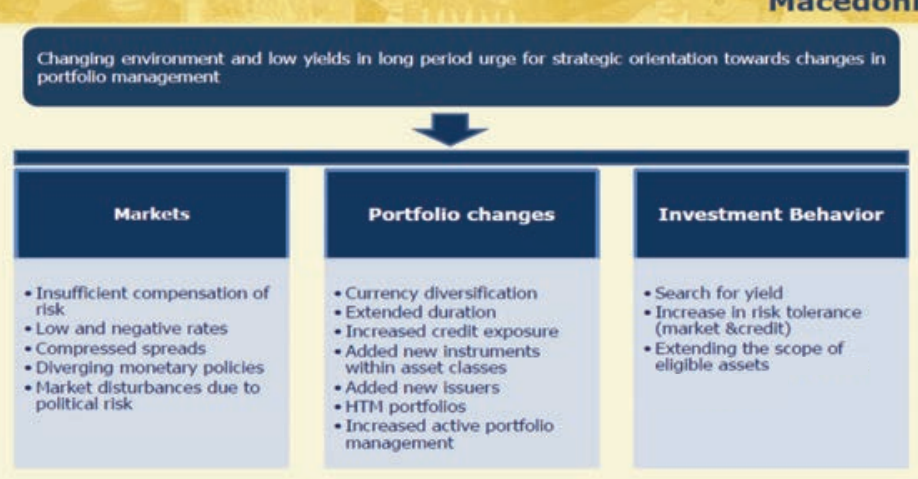

Considering the tranching of the reserves, the liquidity objective for us is very important, because we need ample liquidity to intervene in the FX market and to service the government's debt obligations. Since 2016, we have introduced a new portfolio: the working capital or operational portfolio. It is predominantly in euro and it is covering one-month needs for interventions and services of government

Figure 9. FX reserves management. Macedonia (7)

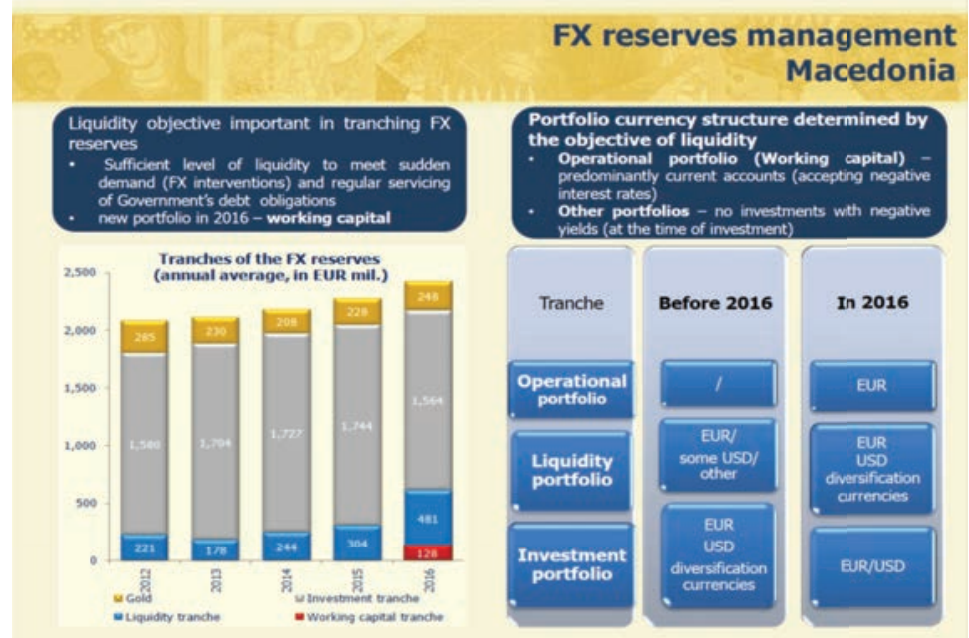


obligations. On the other hand, the liquidity portfolio is based on the rolling principle; it should mostly cover the working capital needs for 12 months in advance on a rolling basis. And the rest is the investment portfolio.

We keep the operational portfolio only in euro, whereas in the liquidity portfolio, we have euro, US dollars, and other currencies in which we have diversified our reserves since 2012. We have also introduced commodity currencies in our portfolio like the Canadian dollar, Pound sterling, Norwegian krone, and other currencies. In the investment portfolio, we still have the euro and US dollar. The euro is the dominant currency excluding gold, which accounts for around 10 percent of our reserves. As of 2016, we have around 60 percent of the reserves in euro and around 40 percent in US dollars. You can see from Figure 10 on the left-hand chart that we started to increase the exposure toward the US dollar from 2014 and it is unhedged, whereas the exposure towards other currencies declined from a combined 10 percent of our total reserves in 2015 to less than 1 percent in 2016.

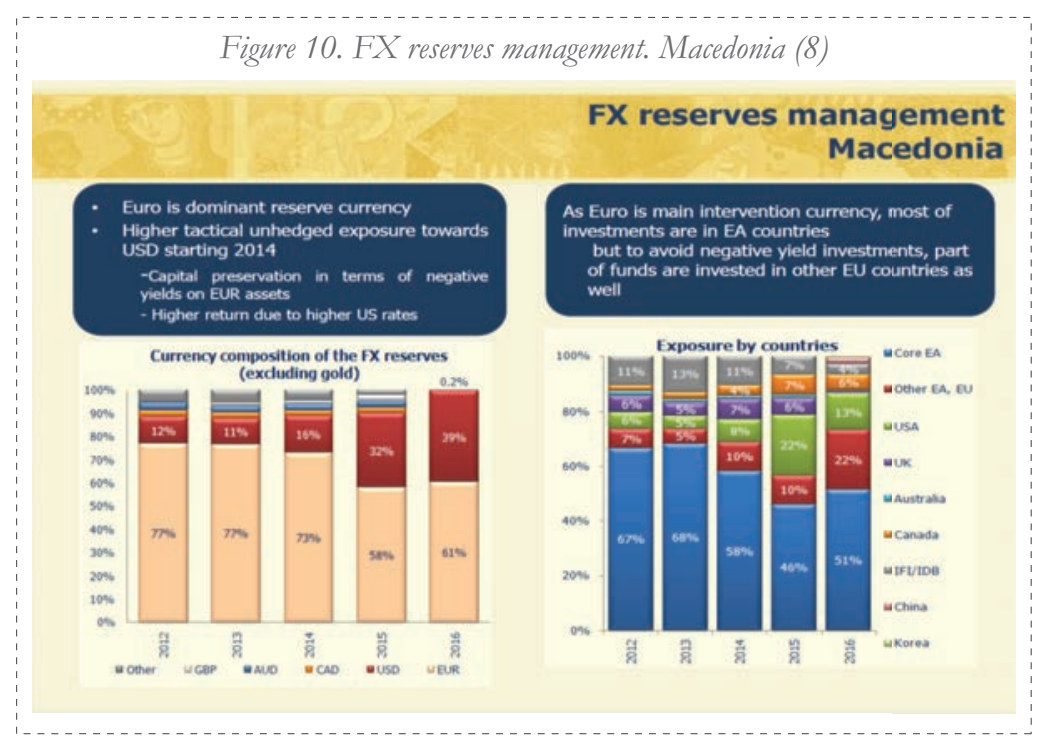

We mostly invest euro in euro area countries, but, to avoid negative yields, a part of the funds is invested in other EU countries as well. In 2016 and now also in 2017, we have also increased investments in securities issued by Asian issuers. 
How are we coping with the risk? I said earlier on during my presentation that the US dollars position is unhedged, but as Roberto previously mentioned, central banks have sometimes some buffers. In the case of our central bank, we have revaluation reserves for exchange rate differentials from previous years. So, from a currency risk management perspective, we did not leave the currency risk unmanaged, but we precisely quantify our currency risk and have an upper limit to the exposure we can take.

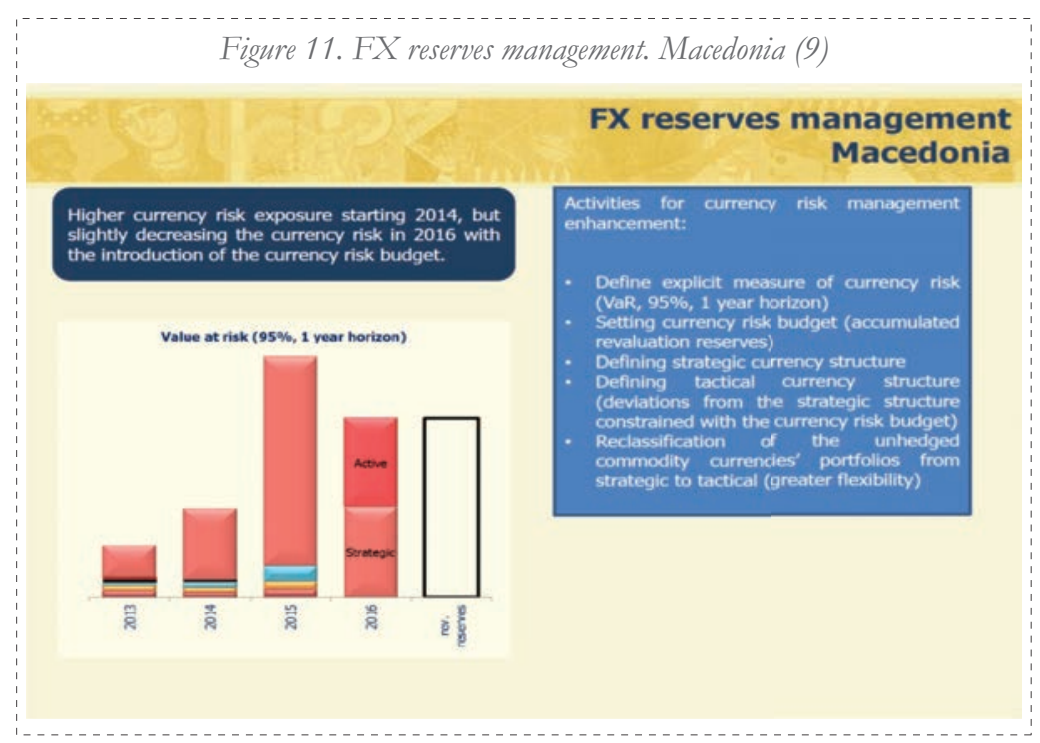

Thus, we have a defined explicit measure of currency risk, which is $\mathrm{VaR}$ at 95 percent confidence interval over a one-year horizon. Then, we introduced the so-called currency risk budget, which consists of the accumulated revaluation reserves from previous years. This is the upper limit for the FX exposure. We divided the currency risk into strategic and active risks. The strategic one is that we need to have US dollars without any activity for active management. That means that for some import purposes, we need to have, for example, 20 percent of the US dollars and it needs to be there. But, as I mentioned, we have 40 percent of our FX reserves in US dollars, 20 percent above the strategic level of 20 percent. So we have some active position in the currency risk and both strategic and active currency risk, as you can see from Figure 11, are below the revaluation reserves of the central bank. Also, other unhedged commodity currencies, which I 
mentioned previously, are not strategic but tactical ones.

For interest rate risk, we extended in the past years the duration as part of our efforts to avoid negative yields. Hence, we accepted higher interest rate risk. We increased the duration mainly for the euro portfolio and we never invested at negative yields, except for the working capital tranche.

As part of our efforts to avoid negative yields, we also increased the credit risk exposure at the end of 2016 and the beginning of 2017. The additional credit risk allowed us to avoid negative yields while decreasing the interest rate risk. In the previous years, the duration was increased, but in the second half of the last year, and the beginning of 2017, we decreased rapidly the interest rate risk and increased the credit risk.

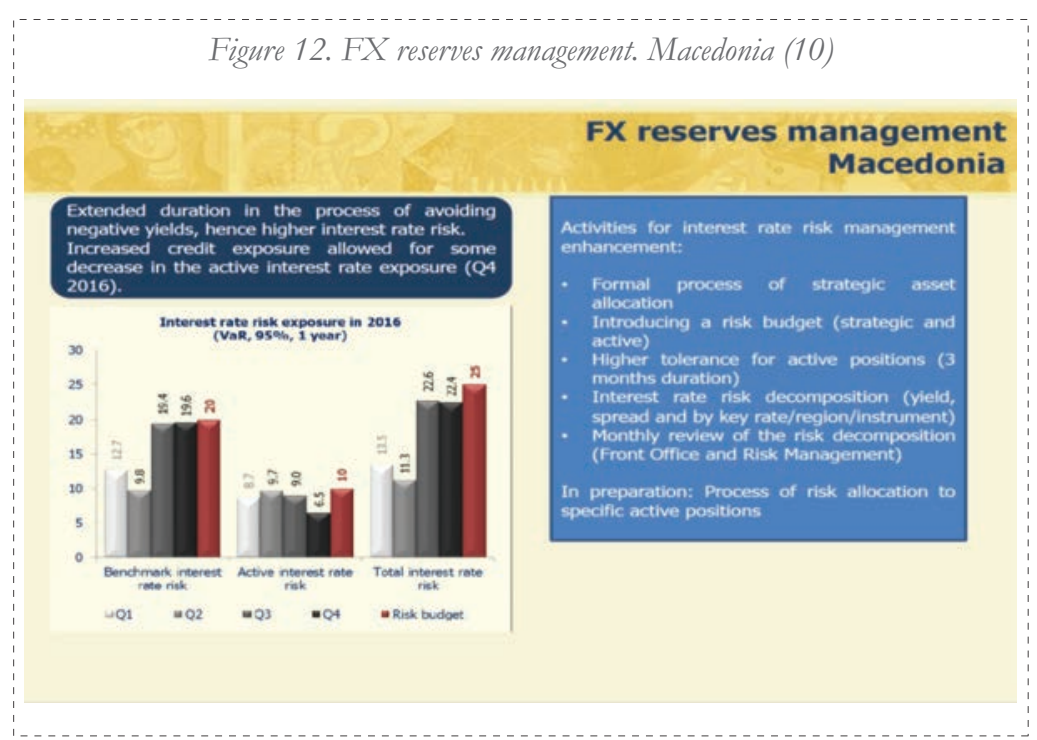

In order to avoid the effects of rising yields and improve interest rate risk management, the formal process of the strategic asset allocation was developed. We also introduced the risk budget and divided it for the actual portfolio and for the benchmark. The risk budget for the benchmark represents the strategic risk budget, which is complemented by an active risk budget for the active position taking of portfolio managers. You can see from Figure 12 that strategic and 
also active risks never were above the risk budget in total, which is EUR 25 million for benchmark and the active positions. We are in the process of allocating the risk to specific active positions.

As regards asset allocation, the structure of FX reserves is rather conservative since 80 percent of our FX reserves are invested in fixed income instruments, but we have also investments in gold and money market deposits. In the second half of last year and at the beginning of this year, we have increased the placement of money market deposits and we have introduced commercial papers and certificate of deposit as eligible investment instruments as part of our coordinated response to rising yields.

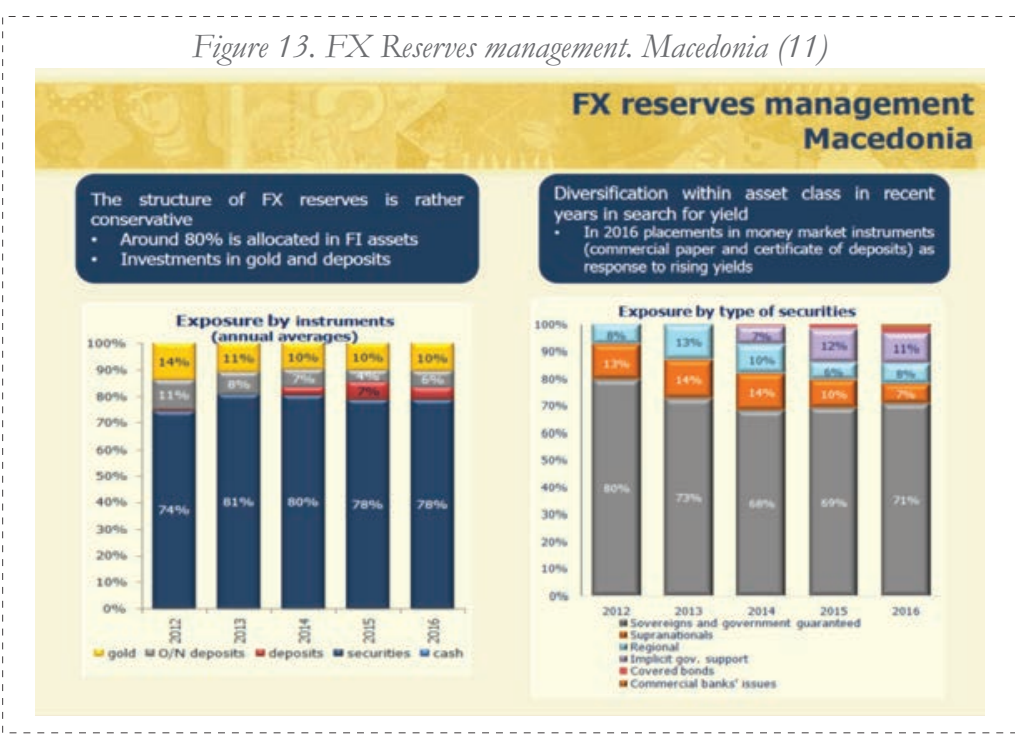

You can see from Figure 13 how the asset allocation is changing, and the part of exposure to commercial banks issues is increasing. This is also driven by the decreasing duration of old portfolios. About credit exposure, our criteria for credit risk have been slightly loosened. The policy document from the Board does not formally allow any investment in assets with credit rating below the investment grade, but de facto the internal guidelines set out stricter and more prudent credit risk criteria. 
Figure 14. FX reserves management. Macedonia (12)

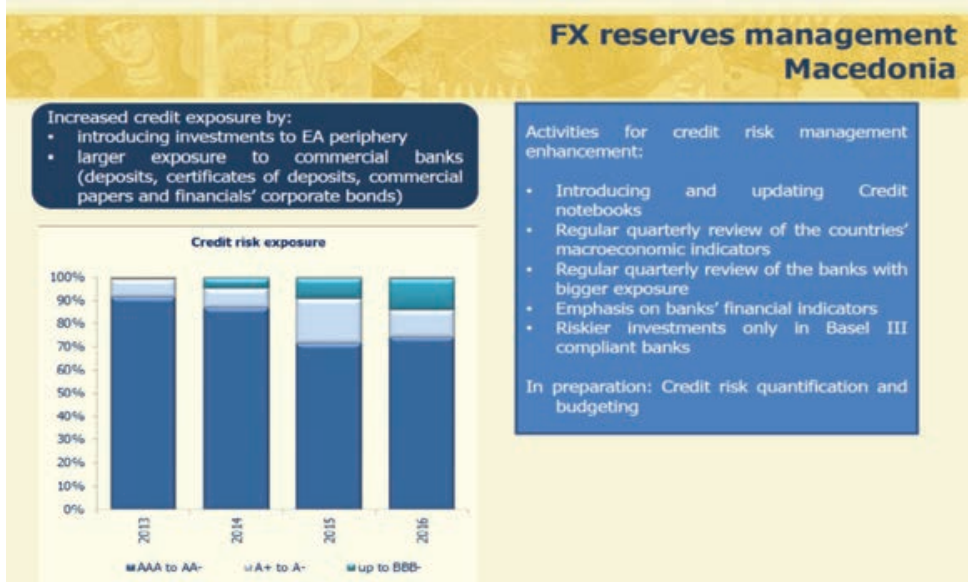

For the credit risk management, due to increased credit risk, we introduced an updated credit notebook, meaning that we follow more deeply the performance of major commercial banks. We have also a quarterly review of the countries' macroeconomic indicators and, in addition, a quarterly review of the banks with which we have larger exposures. We look at the banks' financial indicators, and riskier investments are only with Basel III-compliant banks.

What is in preparation? As we came up with a figure for the currency risk and interest rate risk budget, a model to quantify the credit risk is in preparation to come up with a figure for the total credit risk that we are exposed to.

About gold, we have a constant share of gold in the FX reserves in strategic orientation, and we place most of the gold into deposits. 


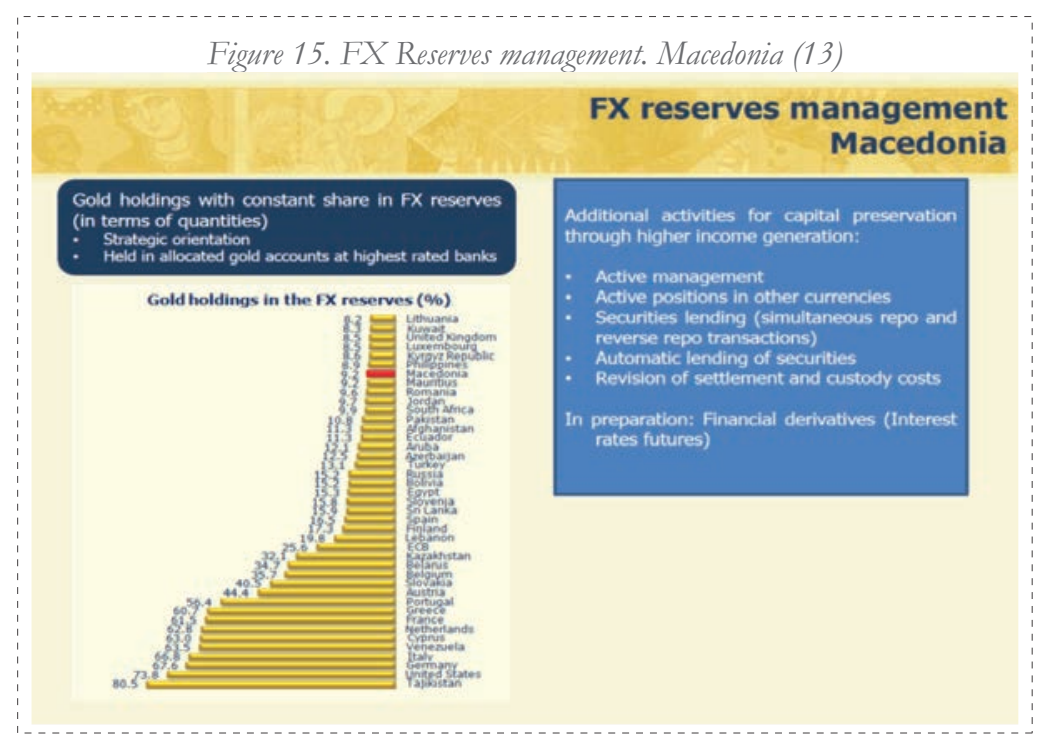

What are additional activities we undertake for capital preservation and to generate higher income? We have active management, active positions in other currencies, and we undertake securities lending and repo and reverse repo transactions under GMR agreements with a few commercial banks. We have agreements for automatic securities lending with our custodians and regularly revisit settlement and custody costs.

We are currently aiming at introducing financial derivatives, namely interest rate futures, as part of our active portfolio management eligible instruments, although for the part of the RAMP portfolio (that the World Bank is managing for us), futures are already used. So, currently we are in the process of building our institutional capacity for transacting in futures. 


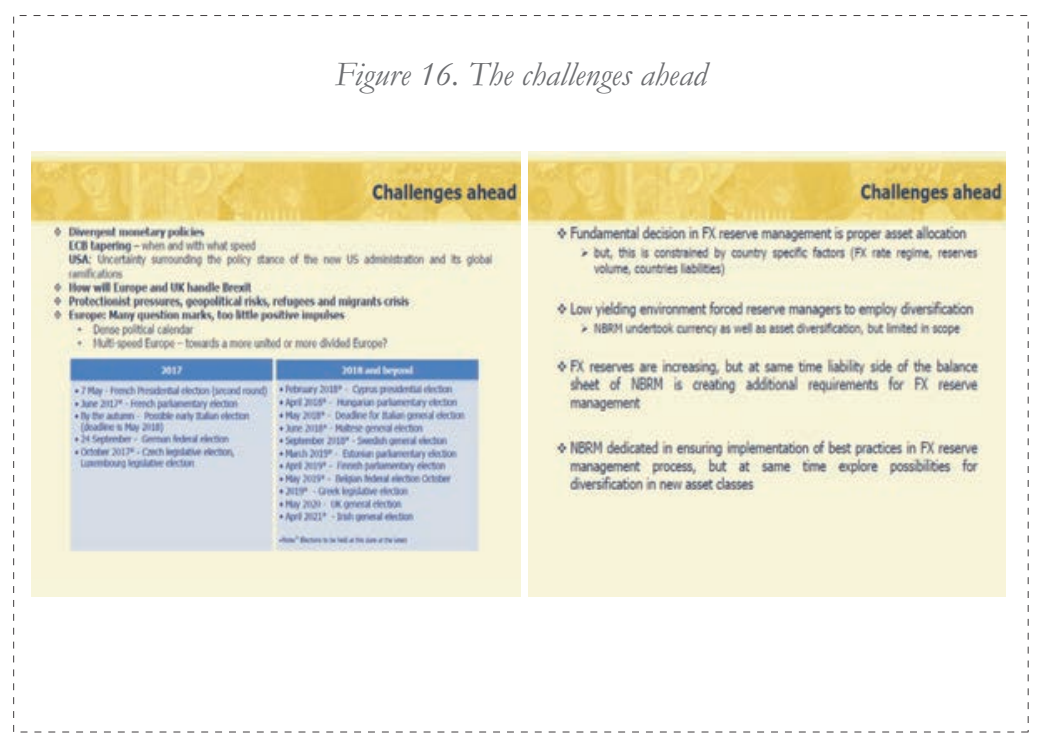

What are the challenges ahead? Of course, there are divergent monetary policies, and ECB tapering - when and with what speed. In the US, there is uncertainty surrounding the policy stance of the new US administration and its global ramifications.

From a political perspective, the challenges include the Brexit negotiations between the EU and UK, the protectionist pressures, the geopolitical risks, as well as the refugees and migrants crises. In Europe there are many question marks, and too little positive impulses with a dense political calendar and the fundamental question of whether we will have a multi speed Europe - a more divided Europe - or Europe will find a new political and economic cohesion.

About us, of course, the fundamental decision is how to properly allocate our investments to asset classes. This is constrained by our country's specific factors, as we have our exchange rate regime. We need to take into account our reserves levels and the country's liabilities.

Then the low yielding environment forced reserve managers to employ diversification. The National Bank of the Republic of 
Macedonia (NBRM) has undertaken currency as well as asset diversification, but limit them in scope.

FX reserves are increasing, but, at the same time, the liability side of the balance sheet of the NBRM is creating additional requirements for FX reserve management, and the NBRM is dedicated to ensuring implementation of best practices of the FX reserve management process, and, at the same time, to exploring possibilities for diversification in new asset classes. 
This page intentionally left blank 


\section{FIFTH SESSION: \\ NEGATIVE EURO AREA INTEREST \\ RATES AND MONETARY POLICY \\ IN THE PROXIMITY OF THE EURO AREA \\ Moderator: Guido Della Valle, \\ International Monetary Fund, Monetary Policy Advisor}


This page intentionally left blank 


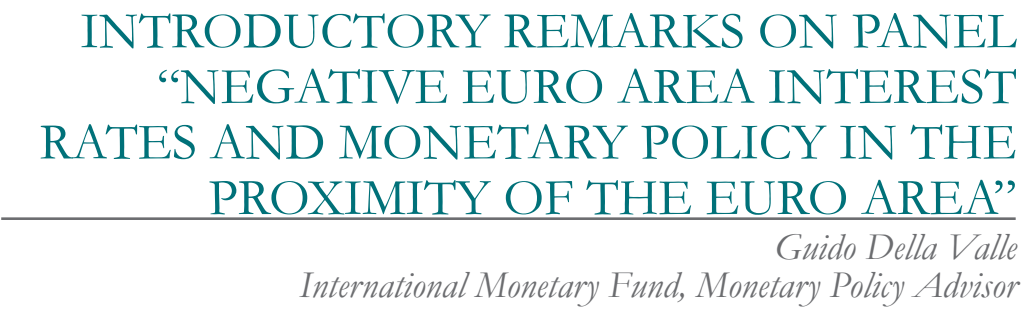

After a very interesting first day of the conference, I am honored to start the second day and introduce a panel of highly distinguished central banks' senior policymakers and economists.

Yesterday we focused on the repercussions of negative euro area policy rates on financial stability and reserve management of the countries in the region and beyond. Today's focus is on monetary policy. In the first session, we will hear the experience of the ECB itself and from a few countries in the euro area proximity that also braced with the spillover from the euro area and had to make recourse to a different set of standard and non-standard monetary policy tools.

We start with a keynote address from Ryan Banjeree, Senior Economist in the Monetary and Economic Department at BIS and formerly Senior Economist at the Bank of England. I think most of you may have come across Ryan's research papers, which span a wide array of topics. Inter alia, he has published papers on the effects of unconventional monetary policy and monetary policy spillovers. I think Ryan's keynote speech will ideally set the scene for the entire day since he will provide a broad but very insightful overview of the consequences of negative euro area policy rates on the conduct of monetary policy in the proximity of the euro area.

We will then have four panelists. Ulrich Bindseil, Director General of the ECB's Directorate General Market Operations, architect of the ECB monetary policy implementation framework, and leading contributor to the design of the recent ECB monetary policy actions 
during the crisis, will give us unique insight into the rationale of accommodating ECB monetary policy, and ECB's own experience and current outlook.

We have then Thomas Moser from Swiss National Bank (SNB). Thomas is Alternate Member of the Governing Board of SNB, with experience at the IMF as Executive Director of the IMF constituency in Washington headed by Switzerland. We will hear from Thomas the SNB's unique experience. Bracing with safe haven currency inflows from the euro area during the sovereign bond crisis, SNB first lowered the interest rate to zero and announced a floor to the CHF/EUR exchange rate to prevent a destabilizing exchange rate appreciation. Later on, it reconsidered the lower policy rate bound, abandoned the floor, and lowered interest rates where nobody had dared before. At the same time, via the tiered remuneration of reserves it shielded at least in part banks from a negative profitability impact. I am looking forward to hearing from Thomas also because he will touch upon several themes from the time varying lower bound, the combination of standard and non-standard tools, and the use of tools to mitigate some of the negative consequences of negative interest rates, thereby lowering the effective lower bound, which will be the focus of my presentation later on.

We have then Dana Hajkova, Advisor to the Bank Board of Czech National Bank,(CNB), and Daniel Felcser, of Magyar Nemzeti Bank (MNB). The Czech Republic and Hungary are two countries in the EU proximity in Central and Eastern Europe that have also coped with the consequences of low euro area interest rates but, interestingly, have taken different approaches. Czech National Bank lowered policy rates practically to zero and then reverted to non-standard monetary policy tools in the form of a koruna/euro exchange rate floor, which they successfully defended and recently decided to discontinue as an additional instrument for easing the monetary conditions. By taking this step, the CNB returned to the conventional monetary policy regime, in which interest rates are the main policy instrument. MNB also returned to a mix of standard and non-standard tools, but was likely driven by a context in which vulnerabilities to exchange rate movements were higher due to the high share of FX loans and some impairment in the bank lending 
channel due to the consequences of past NPLs, implemented nonstandard monetary policy prevalently via the funding for growth scheme.

Therefore a very interesting panel, with different countries reacting to the same context in different manners, with different considerations on the effective lower policy rate bound, and the most appropriate non-standard tools to provide additional accommodation at the lower bound. 
This page intentionally left blank 


\section{MONETARY POLICY IN THE PROXIMITY OF THE EURO AREA: WHAT CHANGES WITH NEGATIVE EURO AREA RATES?}

Ryan Banerjee

Bank for International Settlement, Senior Economist

The title of my presentation is not very catchy. Catchy titles should fit on one line. I think my research papers tend to have un-catchy titles, which is probably why I am in central banking and not politics. But I think it conveys what I want to say. Has something changed with negative euro area rates? Are the spillovers that we see in countries around the euro area the same as before or are they different? I'll try to highlight what I consider to be normal spillovers. I will then discuss some channels through which one may experience deviations from normal spillovers with negative rates based on some of my research. In my remarks, I am going to try to address three points, that were raised by Governor Sejko in his opening address.

The first is the effect of the change in relative yields across countries due to negative euro area interest rates. The second point I'd like to discuss is how low inflation in the euro area may be spilling over to other countries in the region. The third point is the effect of negative interest rates on capital flows, especially given the high concentration of euro area banks in the region. 
Figure 1. What changes with negative rates?

What changes with negative rates?

- Theory: Need to argue why transmission of spillovers change with policy rates at zero

- Empirics: Hard to isolate pure effect of negative rates from $\mathrm{ECB}$ balance sheet expansion

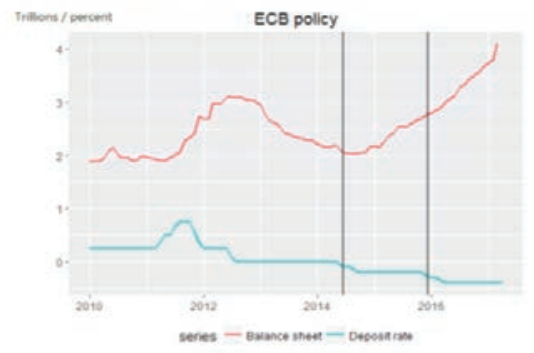

With that, I am going to start with this slide (Figure 1), which shows the ECB policy actions since 2010. If we want to understand what has changed with negative euro area rates, from a theoretical perspective, we need to argue why the transmission of spillovers changes with negative interest rates. A potential mechanism runs through the effective lower bound on nominal interest rates. There is also an empirical challenge. In the figure above, the blue line shows the ECB deposit rate, the red line shows the size of the ECB balance sheet, and the two black vertical lines pick out the two points when ECB interest rates were decreased first into negative territory and then cut again. What you see is that it is pretty hard to empirically isolate the pure effect of negative rates from ECB balance sheet expansion. So, I am not going to do that here. However, I will try to illustrate how spillovers may change with negative interest rates.

I am going to base part of my talk on a paper I have written with Mick Devereux from the University of British Colombia and my colleague Giovanni Lombardo, mentioned in Figure 2. As you see, another paper with a not very catchy title, but basically what we do in this paper is to first establish some empirical facts about monetary policy spillovers. In this case, we looked at US monetary policy spillovers to emerging economies, principally in Asia or Latin America. We 
then explain these facts by adding certain types of financial frictions to a standard two-country Dynamic Stochastic General Equilibrium (DSGE) model. In our model there are two frictions that seem to be important in explaining how US interest rate changes affect emerging economies.

First, there is something that we call a double banking friction. That is, the banks in the center country, for example, the euro area, face a collateral constraint. When interest rates are cut, this raises the net worth of the banks, which in turn raises not only their domestic lending, but also cross-border lending to banks in emerging economies for example, Southeastern Europe. The second aspect of this spillover is that many emerging economies have foreign currency debt, and so movements in the exchange rate caused by interest rate changes affects the relative value of assets and liabilities, which amplifies the cross-border lending spillover.

In our model, we show that with these frictions there is little advantage from following an inflation targeting rule over a fixed exchange rate rule. So, it is interesting given the talks we heard yesterday that although countries in the region have quite different monetary arrangements: some have floating exchange rates, such as Serbia or Albania, others have currency boards - Bosnia - and some are completely euroized,

Figure 2. Normal spillovers from monetary policy

What are "normal" spillovers from monetary policy

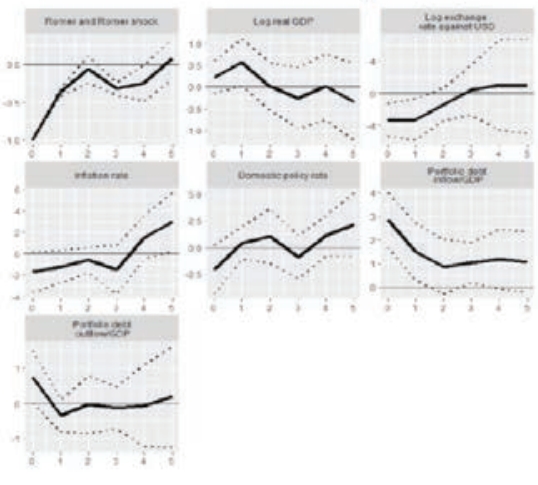

- Cut in US policy rates

- GDP 1

- Exchange rate $T$

- Inflationt

- Policy rates 1

- "Follow the centre country policy"

- Gross capital inflows 1

- Gross capital outflows 1

- Banking sector interaction is important 
the outcomes do not seem so different. This may be partly due to the effect of these financial frictions, so that there is little to be gained from one monetary arrangement over the other, at least in terms of short-term macroeconomic stabilization and spillovers.

Let me turn to characterizing normal spillovers from monetary policy. In Figure 2 above, we estimate the effect of a cut in US policy rates using narrative monetary policy shocks from Romer and Romer before interest rates hit the effective lower bound. Overall, a reduction in US policy rates generates an expansion in emerging economies. But where is this coming from?

First, the exchange rate in the emerging economy appreciates. Associated with the appreciation is a fall in the inflation rate of the emerging economy, potentially driven by the exchange rate appreciation. There is also an emerging economy policy response. When the US cuts the policy rate, other countries also cut rates and so they seem to follow the policy of the center country. That is the first block on the right there, where following the center country policy seems to be the standard response.

The second part covers the effect on gross capital flows. On the one hand, when interest rates are cut in the center, there is an increase in capital inflows into emerging economies. But, there is also an increase in capital outflows from emerging economies to the center. This is what we call a retrenchment effect. The increase in capital flows in both directions suggests that the banking or the financial sector plays an important role in transmitting monetary policy spillovers not only toward emerging economies but also to the center country. I am going to talk about how spillovers may change with negative interest rates in these two blocks.

The first thing that changes with negative rates is that a country may not be able to follow the leader anymore because it hits the effective lower bound. The second point, which seems to be different from a normal monetary policy cut, is that any compression in the banking sector profitability following negative rates may weaken cross-border spillovers through the banking sector. 
Figure 3. Negative euro area rates and effective lower bound (1)

Negative EA rates and the effective lower bound (1)

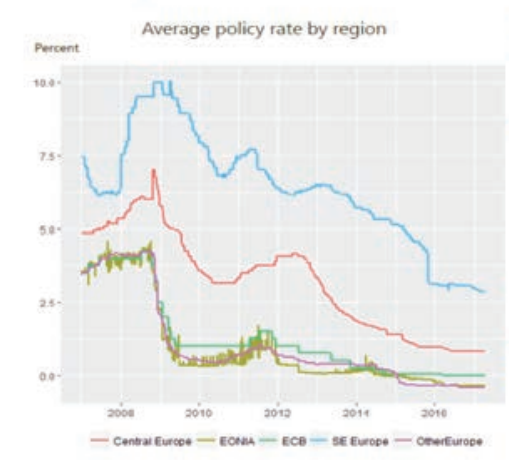

- Desire to follow ECB rate cuts forces some countries to hit the effective lower bound

- Average interest rates spreads of country groups broadly similar to 2007

- SE Europe $\approx 3 p p$

- Central Europe $\approx 1 p p$

- Other Europe $\approx 0 p p$

- Nothing changed with negative euro area rates?

Has anything really changed with the effective lower bound? Let's look at some data on policy rates shown in Figure 3. I have split the countries around the euro area into three groups and taken simple averages of their policy rates. The green line is the ECB MRO rate and the brown line is the EONIA rate. From the EONIA rate, you get a sense of what is going on with the effective euro area overnight rate. The blue line at the top is Southeastern Europe, the red line is Central Europe, the pink line is average of Switzerland, Sweden, and the United Kingdom. If you look at the average interest rate spread between the euro area and these different groups, in Southeastern Europe the spread was approximately 3 percentage points in 20072008 and that's pretty much what it is today. If you look at the average of the Central European countries, it was about 1 percent in 2007, and is approximately 1 percent today. And if you look at the other countries in Europe, 0 percent in 2007 is pretty much an average 0 percent today.

This then raises the question: has anything really changed with negative euro area rates given that the spread to the euro area has not changed very much? It certainly creates problems for reserves management in central banks, so it is appropriate that the conference covered this topic on the first day. But, in terms of monetary policy, 
it seems that for most economies there really hasn't been anything systematically new about the spillovers from negative euro area rates in terms of the policy response of other monetary authorities.

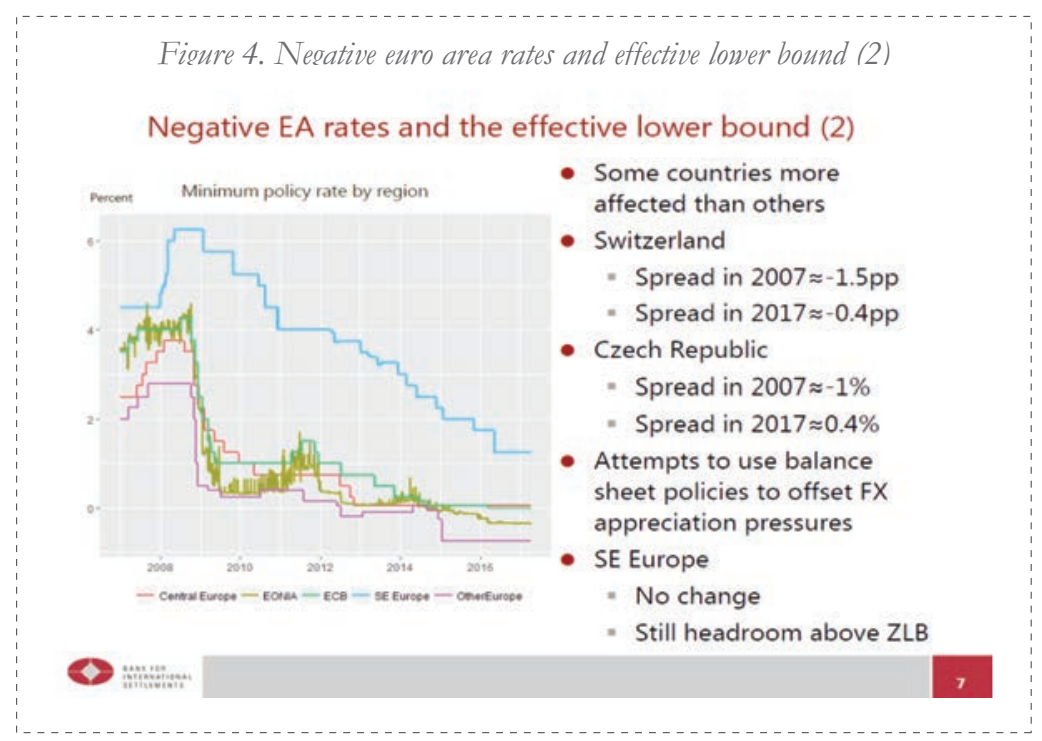

However, moving beyond these averages, there are two countries that appear to have been affected by the lower bound constraint, both of which have historically had, or, at least at the beginning of the crisis, tended to have, rates that were below those of the euro area: the first is Switzerland. In 2007, the spread between the euro area rate and the Swiss Libor rate was -1.5 percentage points, today the spread is approximately -0.4 . They have been unable to maintain this historical wedge with the euro area rate. Another country that had policy rates below the euro area before the crisis was the Czech Republic. Their spread was about -1 percent before the crisis and now they have a positive spread of 0.4 percent. This is evidenced by Figure 4. Perhaps it is no surprise that these two countries are the ones that have used exchange rate policies to try to maintain an effective monetary policy spread between the euro area rates and their own rates in order to offset exchange rate appreciation pressures.

But, when you look at Southern Europe - here I am talking about countries where they have floating exchange rates - there really hasn't 
been much of a change. Even when you look at the minimum of that group in the region, they still seem to have this headroom above the zero lower bound.

Figure 5. Influence of euro area negative rates on inflation expectations

Influence of EA negative rates on inflation expectations

- Does heterogeneity in monetary policy space affect outcomes?

- $\pi_{i t+12}^{e}=0.24 \pi_{i t}-0.08\left(\right.$ defl $\left._{i t}\right)+0.22\left(\right.$ ECBneg $\left._{t}\right)$

$-0.42\left(\right.$ defl $\left._{i t} * E_{C B n e g}\right)+\beta X_{i t}+\varepsilon_{i t}$

- If country not in deflation

- Negative ECB rates raises inflation expectations

- If country experiencing deflation

- Negative ECB rates depresses inflation expectations

6

Does the heterogeneity in the monetary policy space caused by negative euro area rates affect any outcomes?

I ran the very simple regression shown in Figure 5; it is not in any way causal, but I wanted to use it to consider the costs of deflation, given that some countries may be facing more deflationary pressures than others due to exchange rate appreciation. In the regression, next year's inflation expectations from Consensus Economics are regressed on current inflation, a dummy variable indicating whether the country is in deflation or not, a dummy variable indicating when the ECB has negative interest rates, and the interaction between this deflation dummy and a variable indicating when the ECB has negative interest rates.

The coefficient on the ECBnegt term shows that the ECB cut rates into negative territory, was associated with an increase in inflation expectations unless the country was in deflation. However, when an economy was already in deflation, negative ECB rates were associated with more deflationary pressures. Thus, for some countries, negative 
euro area rates may have potentially exacerbated deflationary pressures. What sources of costs may come from deflation if you can't cut rates enough to offset exchange rate appreciation pressures at the effective lower bound? So far, they have not been associated with very bad consequences such as deflationary spirals.

Figure 6. Cost of deflation

\section{Costs from deflation?}

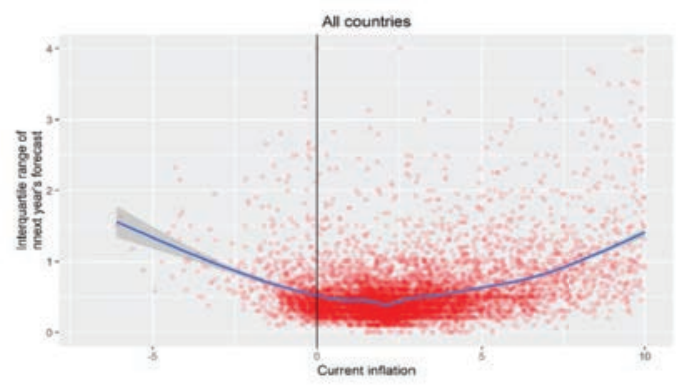

- Dispersion of forecasts rise with deflation

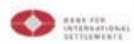

But there might still be other costs. Figure 6 above plots the current inflation rate of a country against the dispersion in next year's inflation forecasts from the consensus panel of economists. What you see is a U-shape relationship. The right tail is a well-known result: when inflation is higher, there is greater dispersion in views on inflation and potentially a greater dispersion in prices. In New Keynesian models, the dispersion of prices is the source of costs from higher inflation as they cause an inefficiently allocation of resources. What this graph shows - which is new - is that there is a similar rise in dispersion as you get into deflation territory; it is almost symmetric. One of the costs of deflation could well be this increased dispersion in inflation expectations. 
Figure 7. Dispersion of forecasts by type of deflation

Dispersion of forecasts: by type of deflation

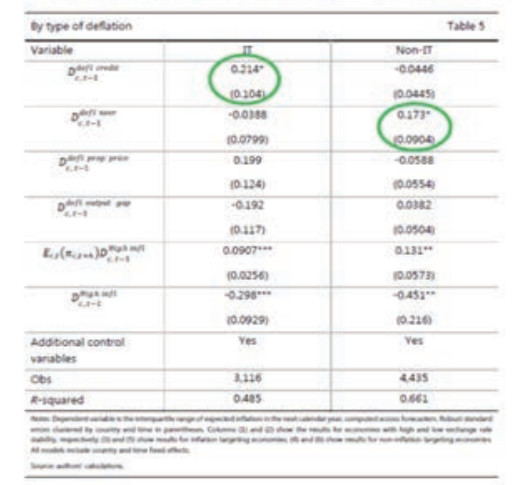

Type of deflation matters

- Deflations associated with high credit levels raise dispersion in IT economies

- Deflations associated with exchange rate appreciation raise dispersion in non-IT economies

But an economy can go into deflation for different reasons. For example, it can go into deflation because the exchange rate appreciated, or because of deleveraging pressures from high debt, which reduces demand. What we do here in Figure 7 is to look at whether the shock, causing deflation, and the monetary policy framework affect the dispersion of views on inflation during deflations. From the top line, it says that if you are in an inflation targeting regime, then there is a significant, positive relationship between deflations associated with high debt and the dispersion in inflation expectations.

However, if you are an inflation targeter, movements in the exchange rate do not have much of an effect on dispersion. But, the story is a little bit different if you are not an inflation targeter. Noninflation targeters experience a significant increase in the dispersion of inflation expectations when exchange rates appreciate. This suggests that as some countries are potentially moving or changing their frameworks away from trying to strongly meet inflation targets over a short horizon, this may increase the dispersion in inflation expectations if the economy is experiencing deflation. 
Figure 8. Role of financial frictions in "normal" spillovers (1)

Role of financial frictions in "normal" spillovers (1)
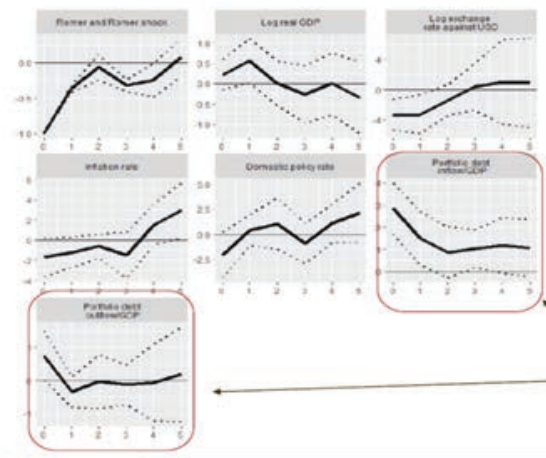

Monetary spillovers amplified by financial frictions

Now let me move on to spillovers through the banking sector and how they may change with negative euro area rates. The last two panels of Figure 8 show the effect of monetary spillovers on crossborder flows, which we explained by financial frictions. In the paper, we have two financial frictions; one is the double banking friction I explained earlier, and the other is that some liabilities in emerging economies may be in foreign currency.

Figure 9. Exchange rate appreciation positive for EME growth

\begin{tabular}{|c|c|c|c|c|c|c|}
\hline & \multicolumn{3}{|c|}{ EMES } & \multicolumn{3}{|c|}{ Adranced economies } \\
\hline & Short-run & Long-nun & $\begin{array}{l}\text { Ratio. } \\
\text { short-run to } \\
\text { long-run }\end{array}$ & shortrun & Long-run & $\begin{array}{l}\text { Ratio } \\
\text { short-run to } \\
\text { long-run }\end{array}$ \\
\hline REER & $\begin{array}{l}-0.103^{* *} \\
10017)\end{array}$ & $\begin{array}{l}-0.1217 \times * \\
(0.040)\end{array}$ & 0.85 & $\begin{array}{l}-0.058 \\
(0.034)\end{array}$ & $\begin{array}{l}-0.104 * 1 . \\
(0.044)\end{array}$ & 0.56 \\
\hline DWER & $\begin{array}{l}01322 \cdots \\
(0025)\end{array}$ & $\begin{array}{l}0105 \cdots \\
(0033)\end{array}$ & 126 & $\begin{array}{l}0026 \\
1002 \pi\end{array}$ & $\begin{array}{l}0.032 \\
(0033)\end{array}$ & 3 \\
\hline Observations & & 1055 & & & 1072 & \\
\hline R-equared & & 0.92 & & & 0.32 & \\
\hline
\end{tabular}

- In countries with high euro denominated liabilities, FX appreciation can be positive for growth 
When interest rates are cut in the center country, it boosts the net worth of banks in the center country. By boosting the center country banks' net worth, this boosts capital inflows into emerging markets. If you have a lot of FX debt, then the currency appreciation also boosts the net worth of emerging market banks, as the value of their liability falls relative to the value of their assets. This then causes a compression in emerging market spreads, which boosts borrowing and growth.

The effect of foreign currency liabilities on growth has been recently discussed in the BIS annual report. You can construct effective exchange rates series in many ways, as shown in Figure 9. It can be based on trade flows using imports and exports. This is the traditional way of measuring an effective exchange rate. Some of my colleagues at the BIS have instead recently constructed effective exchange rates based on the currency composition of an economy's debts, a liabilityweighted exchange rate. For both advanced economies and emerging economies when there is appreciation of the trade weighted exchange rate, this is negative for growth. This is the standard competitiveness channel. But there is a special channel that only seems to operate in emerging economies, which works in the opposite direction. When the debt-weighted exchange rate appreciates because the value of liabilities falls relative to assets - it actually boosts growth in

Figure 10. Negative rates squeeze euro area bank profitability

But negative rates squeeze EA bank profitability

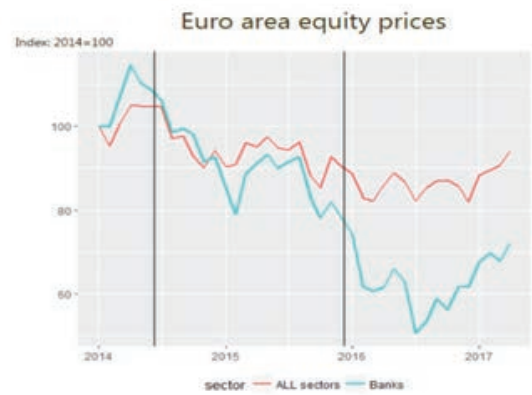

- Lower banking sector net worth following negative rates

- Weaker cross border bank intermediated flows from EA to EA perimeter

- Weaker than "normal" increase in bank credit

- More flows through capital markets?

- Market depth 
emerging economies. This can explain why the spread is somewhat more volatile in emerging economies than in advanced economies. So the movement into negative euro area rates, while it may be negative for the growth of countries like Switzerland, Sweden, and the United Kingdom due to currency appreciation, it may be more positive for emerging economies that have foreign exchange liabilities.

We have seen some of these exchange rate appreciation pressures, so that would result in positive spillovers from the euro area to the region. However, if negative rates impair bank profitability, our model suggests these spillovers might be weaker. Here, as shown in figure 10, I have plotted the equity price index for euro area banks, that's the blue line, and the equity price index for the entire index in the euro area, which is the red line. The two black vertical lines are the points when the ECB cut interest rates into negative territory and when they reduced them further. What you see is that around these announcements, bank equity prices fell relative to the overall market. So, perhaps different from past spillovers, where cuts to policy rates have boosted the net worth of banks, negative interest rates seem to have been associated with a decline in the net worth of euro area banks. In our model, this would imply that negative rates would have a weaker effect on cross-border flows than normal interest rate cuts. As banks typically intermediate credit to households

Figure 11. Lower risk premia following negative euro area rates

Lower risk premia following negative EA rates

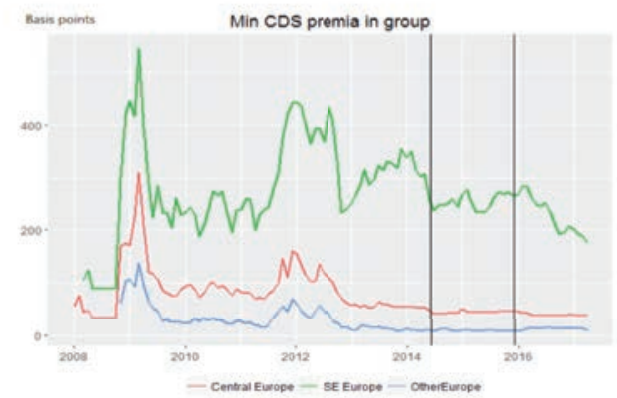

- Sovereign risk spread compression in central and SE Europe 
and to firms, spillovers to these sectors are potentially weaker with negative euro area interest rates. But, a lower capacity of euro area banks to intermediate capital flows may mean greater cross-border intermediation through capital markets. So, with the movement into negative rates, there could be changes in the way spillovers work, depending on the depth of a country's capital markets.

For many countries in the region, the government is the only major issuer of bonds, so capital flows caused by negative rates will tend to go into the government bond market rather than the nongovernment sector. Indeed, there is some evidence of such spillovers to government bond markets in the region. Following ECB policies, which pushed interest rates into negative territory, CDS premia on sovereign debt have declined in Central Europe and Southeastern Europe. This suggests that negative rates reduced the risk premia on sovereigns in both Central Europe and Southeastern Europe, but had little effect on the other European economies.

To conclude, does anything change with negative euro area rates? I highlighted potentially two channels. The first channel is that some countries may hit the effective lower bound. This is more likely in countries with historical interest rates close to the euro area rates. But, if a country had high rates relative to the euro area, it is likely that there would be little difference in spillovers from interest rate differentials. In terms of the effect of negative rates on bank profitability, if there were an adverse effect of negative rates on euro area bank profitability, it would weaken the spillovers through cross-border flows that are intermediated through banks, weakening spillovers to the non-government sector, but potentially increasing spillovers that come through capital markets. 
This page intentionally left blank 
I would like to thank the Bank of Albania for the kind invitation. Costs and benefits of ECB negative deposit policy have been extensively discussed in the euro area, and I understand that it also raises technical challenges for you in the Western Balkans.

\section{MOTIVATION AND OVERVIEW OF ACCOMMODATING ECB MONETARY POLICIES}

First, let me recall the rationale of the low interest rate policy and unconventional monetary policies implemented by the ECB, as well as by other central banks in developed financial markets.

Central bankers use their policy rate to pursue their inflation objective. Central banks consider that in principle, there is at any moment in time, a level of short-term risk-free interest rates, that is in line with reaching in the medium-term the central bank's inflation target. As explained in Figure 1, the theoretical starting point is that the short-term interest rate needs to be equal to the expected return on capital (which, in the steady state, should correspond to expected GDP growth) and expected inflation. If the central bank wishes to exert a disinflationary impulse, it will increase short-term interest rates above the neutral level, that is, the sum of the expected return on capital and expected inflation, and vice versa. Measuring expected inflation is relatively straightforward, while measuring expected return on capital is more difficult. It could be derived from an assessment of GDP growth potential, but various other methods have been proposed. Lately, the neutral interest rate level in the euro area has been very low due to the subdued inflationary expectations and low GDP growth expectations. 
Figure 1. Rationale of non-conventional policy measures

\section{Why non-conventional monetary policy measures?}

Lowering interest rates makes saving less attractive; induces investment and consumption. Wicksellian arbitrage logic provides basic idea:

$$
\text { if } i_{t}<E\left(r_{t}\right)+E\left(\pi_{t}\right) \quad \Rightarrow \text { inflationary impulse } \quad \pi_{t}>E\left(\pi_{t}\right)
$$

if $i_{t}>E\left(r_{t}\right)+E\left(\pi_{t}\right) \quad \Rightarrow$ disinflationary impulse $\pi_{t}<E\left(\pi_{t}\right)$

In recent years the following issues arose:

(I) Low growth / low rate of return on capital, i.e. $E\left(r_{t}\right)$ low

(II) Inflation expectations $E\left(\pi_{t}\right)$ on a downward trend

(III) Increased credit and liquidity spread also affect firms' and households' funding costs missing in arbitrage equation above)

(IV) (I) + (II) + (III) meets zero lower bound problem $\Rightarrow$ constraint on expansionary interest rate impulses

$\Rightarrow$ need to act forcefully, and in time, including through unconventional monetary policy measures: compress spreads (term, liquidity, credit) to reduce actual funding costs of the economy, thereby contribute to make monetary policy expansionary (prevent it to be contractionary)

So, in principle, the central bank can provide inflationary impulses to address deflationary pressures as it controls the interest rate. However, this assumption is confronted with three problems:

a) The first issue is how a central bank's interest rate decisions are transmitted to the effective cost of funding the economy. Factors, that are not under the direct control of the central bank, such as credit and risk premia, influence the cost funding of the economy. Particularly high levels of intermediation spreads would imply an even lower neutral central bank interest rate, everything else equal.

b) The second issue is that the interest rate transmission channel may change once the interest rate reaches a low level, because of other effects of low interest rates that could interact negatively with the inflationary impulse of lower interest rates.

c) Finally, the central bank's choice of the short-term risk-free interest rate is constrained by the so-called zero-lower bound problem. If interest rates fall below a certain negative level, banknotes demand would likely increase very significantly, destabilize the financial system, and undermine low interest rate policies. 
To address the challenges described above, after reducing its policy rates to low levels, the ECB has launched policies to compress spreads: term spreads, liquidity spreads, and credit spreads to reduce actual funding cost. Also, the deposit facility rate was lowered somewhat below zero. This is illustrated by Figure 2 .

Figure 2. Explaining factors of low policy rates

\section{Factors explaining low rates: (iii) increased liquidity and credit spreads}

Composite indicator of the cost of borrowing for NFCs and households for house purchase

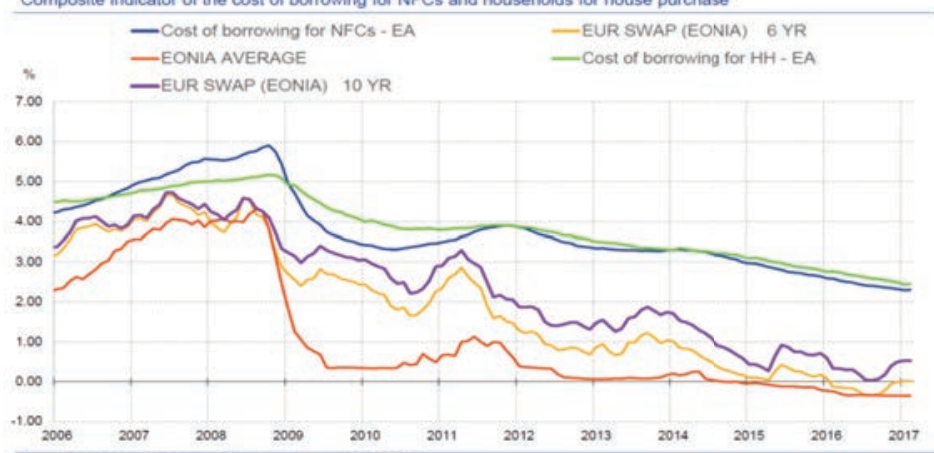

Sources: SDW, ECB staff calculations. Bloomberg. Last update 28/02/2017.

Figure 2 represents the effective cost of funding for households, 10-year maturity, mainly mortgages, and non-financial corporates (NFCs), six-year maturity. In addition, the slide presents the interbank overnight unsecured borrowing cost in the euro area (EONIA), over which the ECB has better control. Finally, the Figure shows 6- and 10-year EONIA swaps, which indicate the risk-free rate for maturities equal to the household interest rate and the NFC interest rate.

In 2006, the spread between the risk-free rate and the actual customer rate was about 50 basis points, with a tendency to increase during the run up toward the first financial crisis. It increased with the first financial crisis (2008) and, even more, during the sovereign debt crisis in the euro area (2011-2012). Since 2012, it has remained in a range between 200 and 250 basis points, despite the unconventional measures taken to compress this spread. 
Inflation forward rates (in particular the five to 10 years forward rate) dropped in 2014 below 2 percent. This was a matter of concern since, as suggested by the equation in Figure 1, if expectations on inflation drop, the implied ex ante real interest rate rises, thereby leading to a tightening of monetary policy when the policy rate is not lowered proportionally. However, the lower bound issue could compound the credibility and monetary policy effectiveness issues, as the central bank has limited room to counteract the lower inflation expectations.

Figure 3. ECB interest rate corridor and EONLA since 1999

\section{Conventional policies: ECB interest rate corridor and EONIA since 1999}

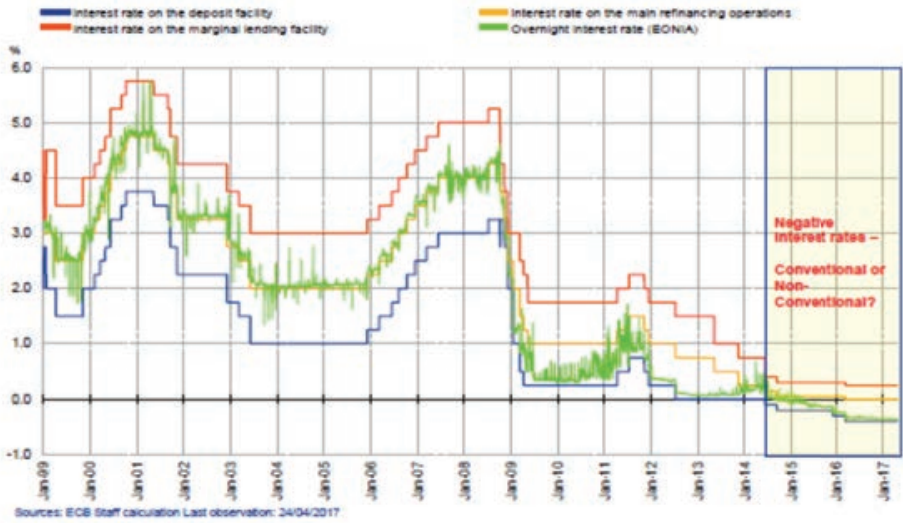

Therefore, central banks should act quickly and forcefully in such a situation. That is what the ECB did.

Figure 3 shows the ECB policy rates and EONIA since 2009. One could notice that the deposit facility rate and EONIA moved in negative interest rate territory. Is it a conventional or unconventional monetary policy action? On one hand, it is conventional, as it follows standard monetary policy decision and implementation logic, based on the policy rate. On the other hand, it is unconventional, as negative interest rates had never been applied before in the euro area.

The other side of unconventional monetary policy is what you can see in the balance sheet of the euro system. Figure 4 shows 
key measures, announcements, and programs. The first dot in the chart is the fine-tuning operation of August 9, 2007, a long time ago. Then follow different announcements, like the ECB President's speech in London in 2012, the OMT announcement, and the PSPP announcement. The programs and their duration are indicated at the bottom. The top part of the chart represents Eurosystem balance sheet items: on the up-side are the asset items and on the lower side are the liability items, including the so-called autonomous factors.

Figure 4. Unconventional polices: Eurosystem balance sheet since 2007

\section{Unconventional policies: ECB balance sheet since 2007}

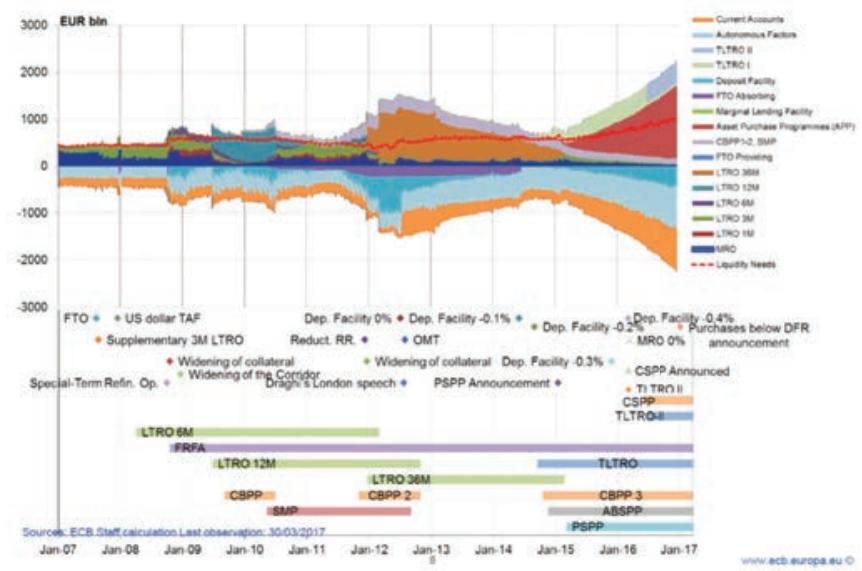

Let me go very quickly through these non-conventional measures. One is our TLTRO-target longer-term refinancing operations. The latest one was launched in June 2016. It is a four-year operation, which is very attractive for the banks. The purpose is to give an extra incentive to expand lending and also to compete via loan rates, to support the transmission from our low rates to the actual funding cost of NFCs. In order to benefit from lower interest rates in the TLTRO, banks should expand lending to corporates, but the loan increase ratio has been set at a relatively moderate level. If banks expand their loans to non-financial corporate by 2 percent over a two-year period, they would pay the deposit facility rate on the Eurosystem refinancing, so minus 40 basis points, as a fixed rate over four years. That explains why the demand has been relatively large. In total now, the Eurosystem provided 761 billion of this 
cheap credit. While the Eurosystem was not the first central bank to introduce negative rates on its liabilities, it was the first central bank to provide banks' funding at negative rates.

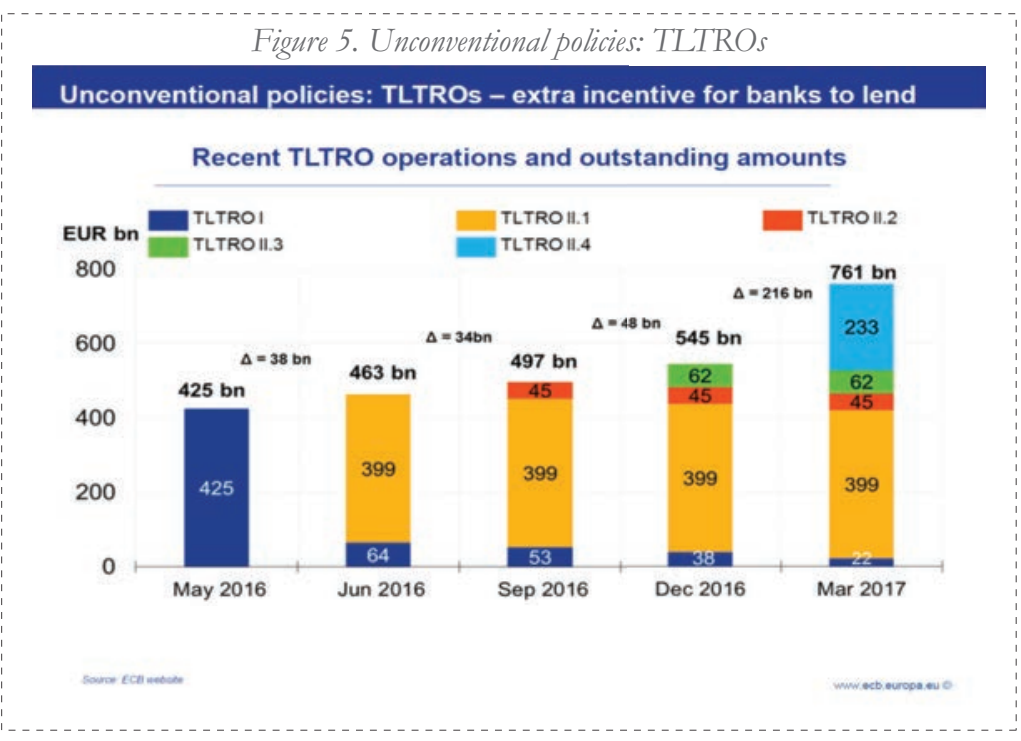

Then comes the asset purchase program of the Eurosystem. Its main purpose is to compress term spreads. Indeed, by buying long-term assets, the central bank compresses term spreads, which should affect funding costs of the economy as the term spread element is a component of the funding cost. The Eurosystem is currently buying government bonds, corporate bonds, covered bonds, and ABS.

One could ask why does the Eurosystem buy all those different assets. The starting point was the universe of debt instruments issued in the euro area, applying certain minimum credit quality criteria. The Eurosystem does not want to favor governments as issuers, and, therefore, also included various private sector bonds in its programs, even if purchasing these often less liquid bonds is technically less convenient. 
Unconventional policies: the ECB's APP to lower term spread

\section{Monthly purchase volumes and composition}

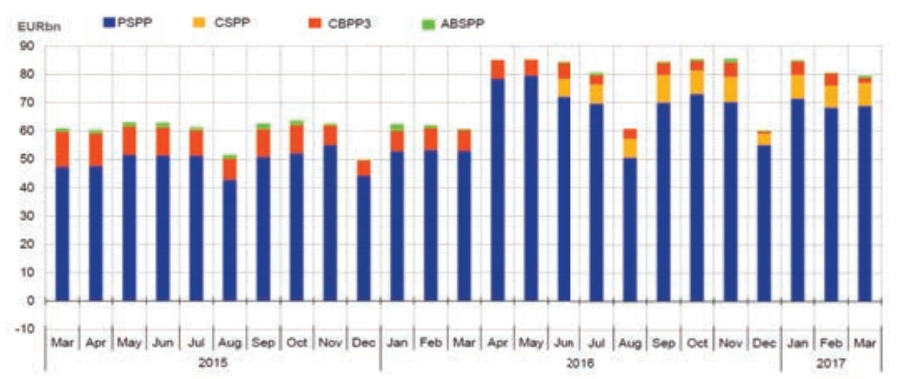

One can note in particular that the ABSPP in Figure 6 is not very important from a mere quantitative perspective. Still, the ECB considered ABS an important asset class that should be included in the Asset Purchase Programme (APP) in view of its potentially important role in financing the euro area real economy. Figure 7 shows a 10 -year German bund yield and the spreads of other countries toward the German 10-year bund.

Figure 7. German bund 10-year yields and spread of other 10-year government bond yields vis-à-vis German bund

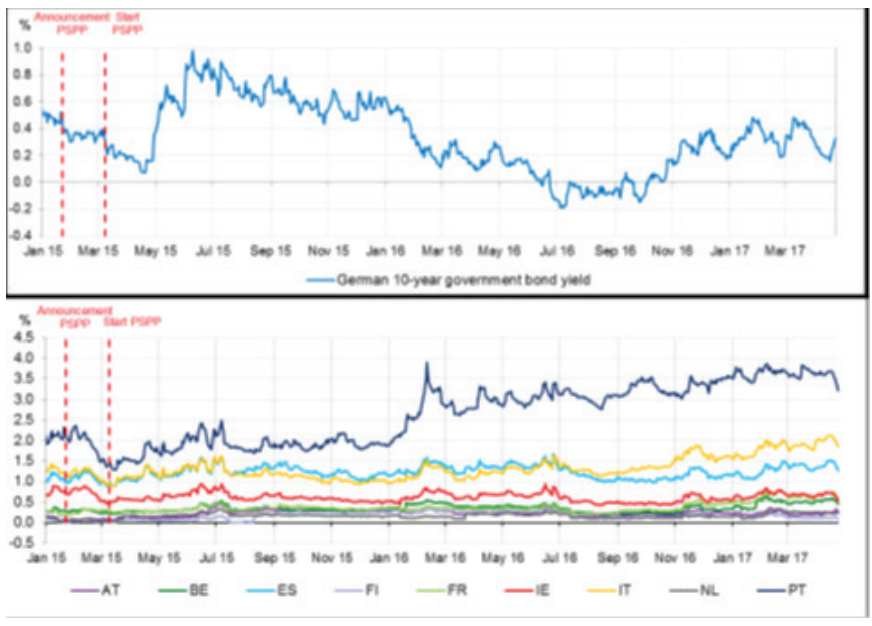


It is difficult to assess the impact of the different purchase programs. There have been a lot of discussions on the need of such programs before they were announced. Therefore, the announcement and implementation only partially came as a surprise and their impact was already partially reflected in prices well before the program announcement. The start of the actual daily purchase flow did not seem to have had an impact on yields.

As the Eurosystem initially decided not to buy securities below the deposit facility rate, the duration of the purchases went higher. The more the yields went down, the higher rose the duration of term purchases, which meant even lower yields. The Eurosystem was subsequently authorized to purchase below the deposit facility rate.

When analyzing the effects on the spreads between the various euro area government bonds, it is important to note that higher rated countries tend to be over-weighted in the purchases relative to market capitalization since the Eurosystem buys according to capital key and not according to the size of the market of the securities to be purchased. Therefore, for example, Italy is underweighted and Germany overweighted in the purchases from a securities market perspective. This could have led to a spread widening. However,

Figure 8. Effects of APP - CSPP

Effects of APP - CSPP

\section{Impact of CSPP on yields}
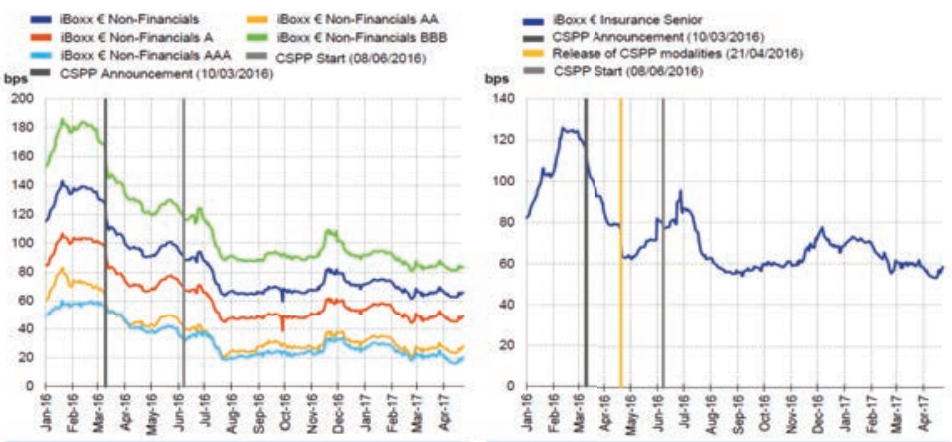

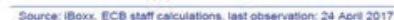


there may have been some opposite effects since the perceived overall positive effects on financial stability and economic developments may have benefitted the somewhat lower rated countries more than the highest rated countries. The overall net effect of the APP on euro area spreads is therefore difficult to assess.

CSPP, the corporate sector purchase program, shows a nice announcement effect, because it was not discussed in the public beforehand. The announcement was relevant. The right-hand chart of Figure 8 shows the iBoxx insurance sector index. Here, the modalities of the CSPP, when they were released in April 2016, had an effect, because it was not clear whether or not the insurance sector would be part of it.

\section{EXPERIENCE WITH NEGATIVE INTEREST RATES}

The Eurosystem did not invent negative policy rates. However, it was the first one to introduce the negative rates in a large monetary area, which did not need it in terms of preventing exchange rate appreciation pressures, but needed it from a domestic monetary policy perspective.

Figure 9. Overview of negative interest rate policies

Overview of negative interest rate policies

\begin{tabular}{|c|c|c|c|c|c|c|}
\hline Central Bank & $\begin{array}{c}\text { FIRST } \\
\text { INTRODUCTION }\end{array}$ & $\begin{array}{c}\text { EFFECTIVE } \\
\text { POUCY RATE }\end{array}$ & NAME & EXEMPTION & Low & CURRENT \\
\hline $\begin{array}{l}\text { Danmarks } \\
\text { Nationalbank }\end{array}$ & $\begin{array}{l}06 / 07 / 2012 \text { and } \\
05 / 09 / 2014\end{array}$ & r & certificate of deposits rate & current account limit & -75 bps & -65 bps \\
\hline $\begin{array}{l}\text { European Central } \\
\text { Bank }\end{array}$ & $11 / 06 / 2014$ & $\gamma^{*}$ & deposit facility rate & reserve requirements & $-40 \mathrm{bps}$ & -40 bps \\
\hline $\begin{array}{l}\text { Swiss National } \\
\text { Bank }\end{array}$ & $22 / 01 / 2015^{* *}$ & v & $\begin{array}{l}\text { mid SNB target range for } 3 \text { - } \\
\text { month CHF UBOR }\end{array}$ & individual exemptions & .75 bps & .75 bps \\
\hline Sveriges Riksbank & $18 / 02 / 2015$ & Y & repo rate & $\begin{array}{l}\text { no, o/n deposits at even } \\
\text { lower rates }\end{array}$ & $.50 \mathrm{bps}$ & -50 bos \\
\hline Norges Bank & $24 / 09 / 2015$ & $\mathrm{~N}$ & reserve rate & all individual quotas & $.50 \mathrm{bps}$ & .50 bps \\
\hline Bank of Japan & $16 / 02 / 2016$ & $\mathrm{~N}$ & Policy-Rate Balance & three tier system & -10 bps & $-10 \mathrm{bps}$ \\
\hline
\end{tabular}

Note: "For the ECB, the deposite facility rate becomes the effective policy rate amid high levels uf excess liquidity. " The 3-month CHF UBOR already moved into negative at announcement on 18 December 2014 
What are the benefits of negative rates in short? Those are conventional benefits of lowering interest rates in the Wicksellian logic. If you need an inflationary impulse and you are close to zero, then you may want to use the possible remaining leeway going negative.

This is the standard logic of conventional monetary policy. In fact, the policy rate cut below zero not only lowered the short-term interest rates, but the entire yield curve went down. Markets beforehand believed that interest rates could not go below zero. Once they actually moved below zero, the whole expectations on future interest rates also changed. The probability distribution of future interest rates now had a tail in negative territory. As a result, the long-end of the curve moved down very effectively with the policy rate cut below zero. This is also what the Bank of Japan experienced when introducing negative rates.

As the benefits of negative rates are standard, much of the literature focuses on the possible negative side effects. Did negative interest rates have side effects that undermined the obvious standard positive effects? The following list of questions comes to mind:

- Would negative interest rates lead to lower money market activity?

- Would negative interest rates lead to a surge in banknotes or in the demand for alternative secure deposits? Does that create an effective lower bound (lower bound type 1)?

- Would the negative interest rate reduce banks' profit? And, then, would banks try to recoup the loss via higher lending rates, which is the opposite effect that the one sought? This is a different kind of effective lower bound (effective lower bound type 2).

- Would negative interest rates encourage investors to take excessive risks, which could endanger financial stability?

- Would negative interest rates discourage structural reforms by easing too much government funding conditions?

The pass-through to money markets was smooth and identical to the one in positive interest rate territory. The Eurosystem announced 
that it would introduce negative rates a few months in advance so that technical (IT) issues could be solved. And, they were solved.

Figure 10. Pass-through of negative policy rates to money market rates

\section{a) Interest rate pass-through}

\section{Pass-through to money markets smooth}

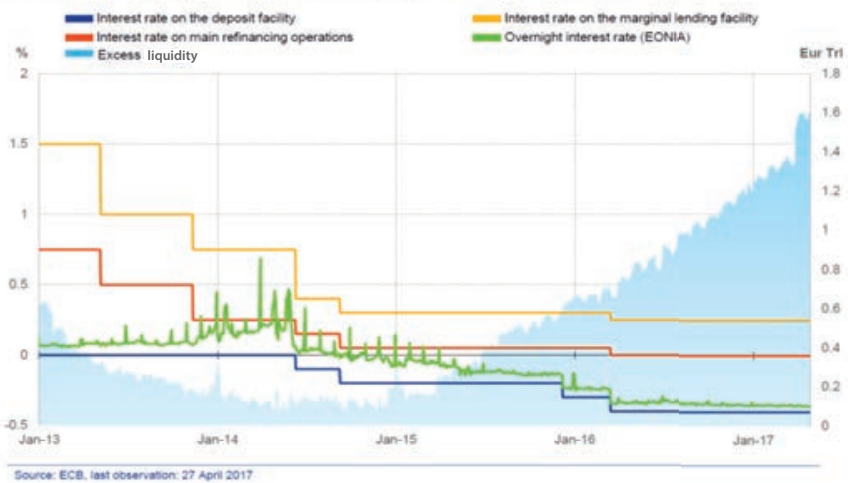

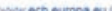

In term of money market volumes, did negative rates affect the turnover in the money markets? More than by negative rates, money market turnover was reduced by large excess liquidity. Every bank has excess reserves, so there is less opportunity for trading liquidity.

Figure 11. Negative interest rates, excess liquidity, and money market activity

\section{b) Money market activity}

\section{Stable repo volumes and lower unsecured volumes amid increasing levels of excess liquidity}

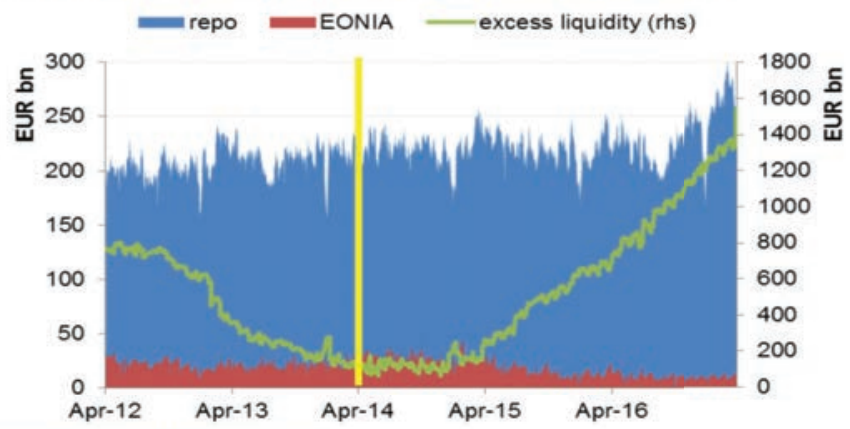

Source: ECB, Brokertec, MTS, Eurex repo, EMM! 
That is what Figure 11 is showing. The yellow line indicates when the Eurosystem introduced the negative deposit facility rate. On volumes, nothing at all happened. The other line, the green line, shows the excess liquidity. As excess reserves increased, EONIA volumes went down. But, the decline in volumes is not due to negative rates.

Figure 12 shows the interest rate pass-through to household and corporate deposits up to one-year maturity in the euro area. It happens that negative interest rates were not passed on to customer or corporate deposits. While remaining positive, corporate deposit rates declined to lower levels than household deposit rates because some corporate deposits were charged negative rates. The zero lower bound seems to have been almost universally applied only on retail deposits.

Figure 12. Negative interest rates, banks' profitability, and pass-through to customers' deposits

\section{d) Bank profitability impact: Interest rate pass-through}

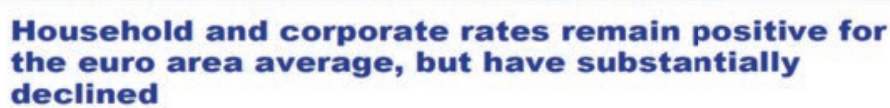
declined
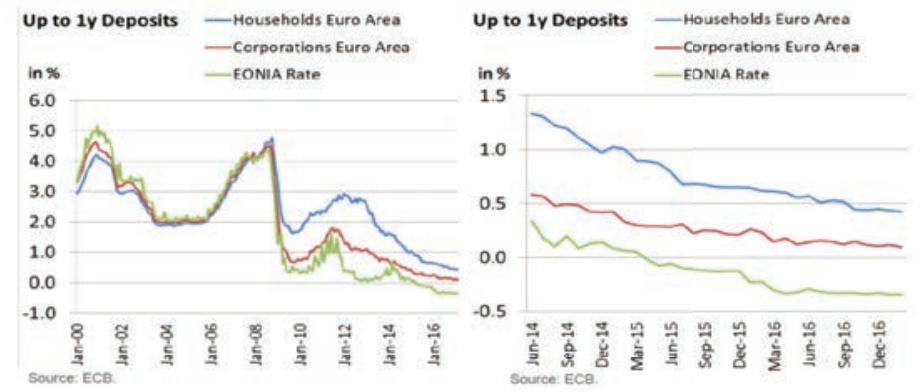

Banknotes' demand might have increased slightly above trend, as shown in Figure 13. But one cannot say that negative rates have made a fundamental difference. 


\section{c) Banknote development (ZLB I ?)}

\section{Banknote increase only slightly above trend}

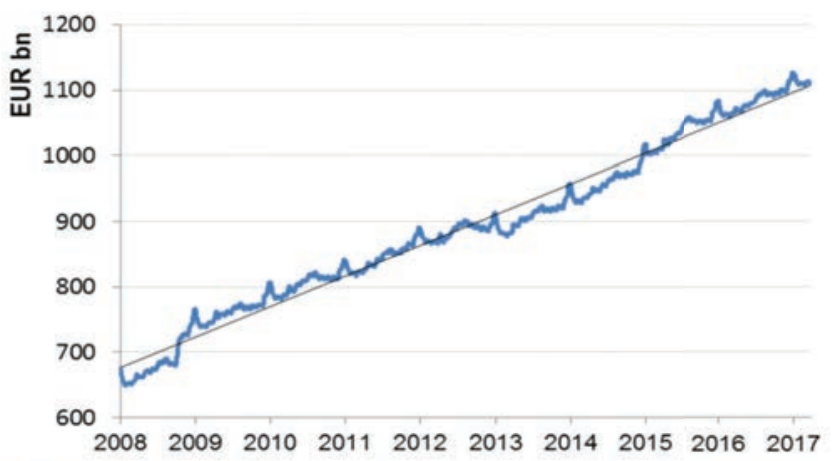

In a certain way, negative rates are merely a continuation of very low rates already characterizing the euro area since the financial crisis, and low rates should already have an upward impact on banknotes demand. The Eurosystem does seem to have reached the effective lower bound type 1. A general view seems to have emerged, however, that the lower bound of type 1 is only reached when negative rates are decreased below the minus 1 percent threshold.

Reserve management accounts, which include accounts of noneuro area public sector investors, went up slightly. However, it is a deliberate policy of the Eurosystem to subject these accounts, as well as government accounts, to -40 basis points, at least to avoid encouraging an increase in the amount deposited on these accounts, while banks are charged 40 basis points on their accounts in the Eurosystem.

With regard to the bank profitability issue, it is important to distinguish the general issue of lower net interest rate margins from the specific one that arises when banks have to hold excess liquidity with the central bank at a negative remuneration rate. 
Figure 14. Negative interest rates and other central bank liabilities towards non-banks

\section{c) Other CB liabilities towards non-banks: central bank accounts?}

Accounts of non-euro area official sector investors have somewhat increased, but attention need to be paid that pricing is not overly attractive

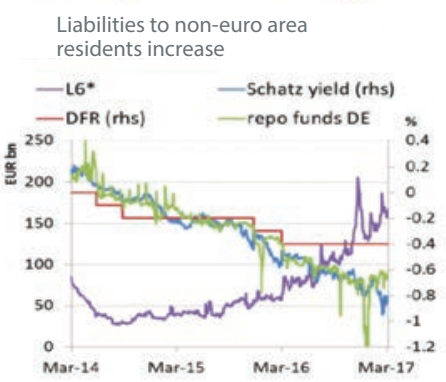

....but not so much in relative terms over the longer run

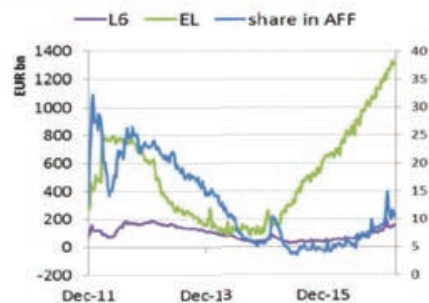

Source: ECB, Woekty Financial Statement and ECB calculations.

Figure 15 shows the results of the analysis conducted by the Eurosystem on the effects on profitability of the different policy instruments deployed. The analysis indicates that the net effect on bank profitability of monetary policy of the last three years is positive.

Figure 15. Monetary policy and effects on banks' profitability

\section{d) Effects on bank profitability - ECB estimate}

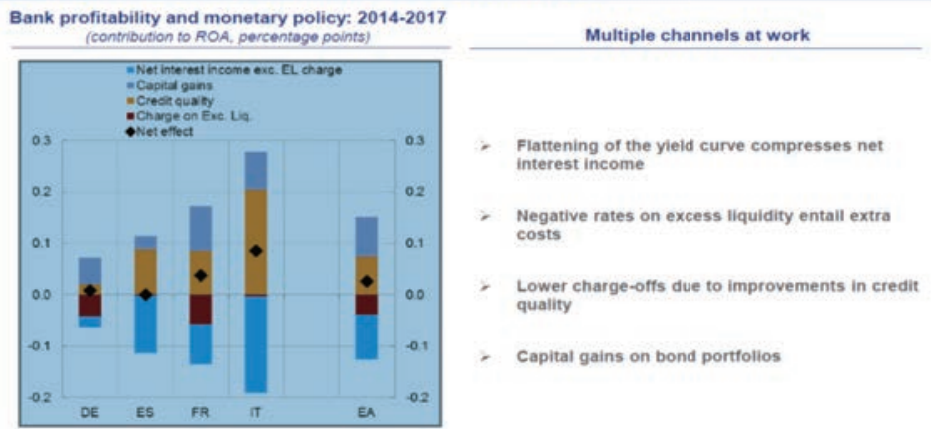

Sources EBA ECB and ECB estimules.

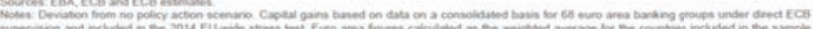

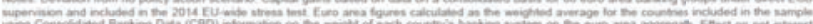

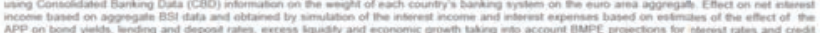

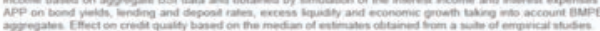


The black dot is a net effect. The effects captured include the positive impact on credit quality and NPLs of accommodative monetary policy. The net interest income impact is indeed negative. This is shown by the blue bar at the bottom.

Figure 16. Cost of external financing of NFCs and household and loan growth

\section{d) ELB II / reversal rate has not been reached}

\section{Costs of external financing of NFCs and households and loan growth}
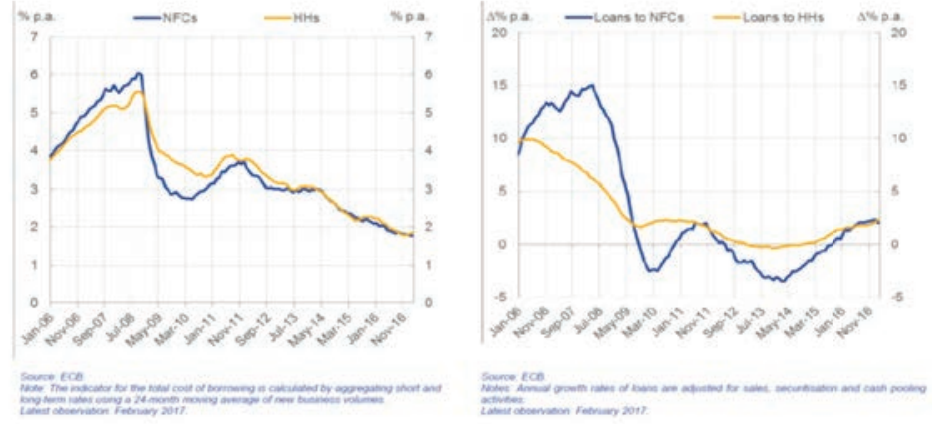

23

Finally, critics of non-standard monetary policy also often give prominence to the associated financial stability risks. Indeed, some investors may be more exposed than others to low interest rates, and might end up taking excessive risks. For example, parts of the insurance industry had been running a maturity mismatch (with a longer duration of liabilities compared to assets), not having considered a scenario of risk-free interest rates becoming negative. However, it can also be argued that low for long and stable interest rates may also support a more precise and more prudent pricing of assets than in a period of high interest rate volatility. So far, there is no convincing evidence that low rates may have encouraged excessive risk-taking and asset misallocation. 
This page intentionally left blank 
I have tried to come up with a sexy title - at least I think it's sexy: "Monetary Policy below the Zero Lower Bound," and I intend to talk about the Swiss experience of conducting monetary policy with negative interest rates.

In the case of Switzerland, the international financial crisis of 2008 manifested itself mainly through a significant exchange rate appreciation. The Swiss franc has traditionally been considered a safe haven currency. Whenever there is a crisis, or when risk is perceived as high, the Swiss franc tends to appreciate. In Figure 1, you can see the real effective exchange rate of the Swiss franc and how the Swiss franc appreciated during the crisis. This appreciation was significant, and it clearly accelerated in the summer of 2011, which led the Swiss National Bank to introduce a temporary exchange rate floor against the euro. The exchange rate floor was in place until January 2015, when we decided to lift it. The Swiss franc experienced then another sizeable appreciation. Since then, the real effective exchange rate depreciated somewhat, partly due to a nominal depreciation, partly due to lower inflation in Switzerland, but overall the Swiss franc remains considerably stronger than before the crisis. 
Figure 1. CHF real effective exchange rate (CPI-based)

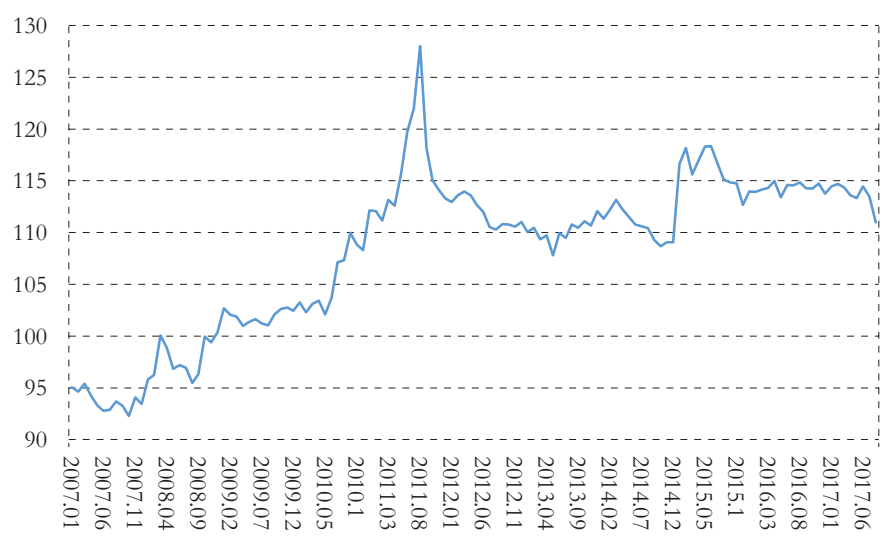

Figure 2 shows the bilateral nominal exchange rates of the Swiss franc against the dollar and the euro. Here too, you can see how the Swiss franc appreciated against both currencies during the crisis, with the dramatic acceleration of the appreciation during the summer of 2011.

Figure 2. Nominal exchange rates: CHF per USD and EUR

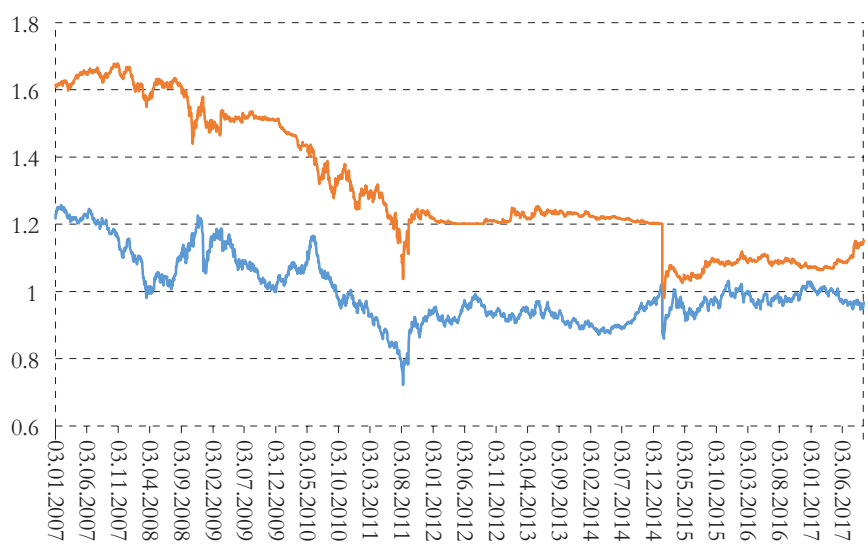

-USD -EUR 
On September 6, 2011, when we announced that the Swiss National Bank would no longer tolerate a EUR/CHF exchange rate below CHF 1.20, the Swiss franc immediately depreciated above CHF 1.20 per euro, and it stayed there for the next three years. Why did we lift the floor in early 2015? One of the questions we had to deal with when we introduced the exchange rate floor was whether we should define such a floor for an effective exchange rate, that is, against a currency basket, or for a bilateral exchange rate. While the first concept makes more sense from a purely economic point of view, the second concept is much easier to communicate and implement. And as long as the Swiss franc was appreciating against all currencies, there was no difference, and, therefore we opted for a floor against the euro. The situation changed in the second half of 2014, when the US dollar and the euro started to move into different directions. As it became clear that the Fed would start to exit from its expansionary monetary policy, and the ECB, on the contrary, prepared a further loosening of its monetary policy stance, a bilateral exchange rate floor against the euro was no longer sensible. Toward the end of 2014, we announced the introduction of negative interest rates, and we introduced them as we lifted the exchange rate floor.

Apart from such a temporary exchange rate floor, which the Swiss National Bank had already once successfully introduced in 1978, we also looked at other options, including the possibility of capital controls. However, we came to the conclusion that such controls would be more difficult to design and implement, if you want to minimize the negative spillovers to the domestic economy. We did make preparations for capital controls, but we considered them more of a last resort, if other measures proved insufficient or if the situation called for more drastic measures.

Regarding negative interest rates, as noted before, we introduced them in early 2015. However, we looked at the possibility of negative interest rates already in 2011, at a time when the concept of negative interest rates was still considered awkward, even within the Swiss National Bank. In fact, I headed the working group preparing the concept of negative interest rates, and one of the first arguments I had was whether there was such a thing as "negative interest rate" and whether we could thus use that term. I think some people 
remained unconvinced until the ECB finally introduced negative interest rates and used that term. But beyond terminology, there was the more serious assertion that negative interest rates were not merely a continuation of values on a scale that goes below zero. Rather, it was argued that lowering interest rates below zero was like cooling water below zero degrees Celsius: the physical properties would change, water would freeze, and you would suddenly be in a very different physical environment. But as Ulrich already noted: we learned that this is not the case. Negative interest rates are a continuation of values on a scale that goes below zero, at least within the range of negative interest rates that we have experienced so far. Nothing unexpected happened; markets and the transmission mechanism continue to work.

The first central bank to actually introduce binding negative interest rates was the Danish National Bank. They did it in 2012, and it provided a welcome case study for us. We were in close contact with the Danish National Bank during that time, and their experience confirmed that negative interest rates could be used to counter appreciation pressure on the exchange rate.

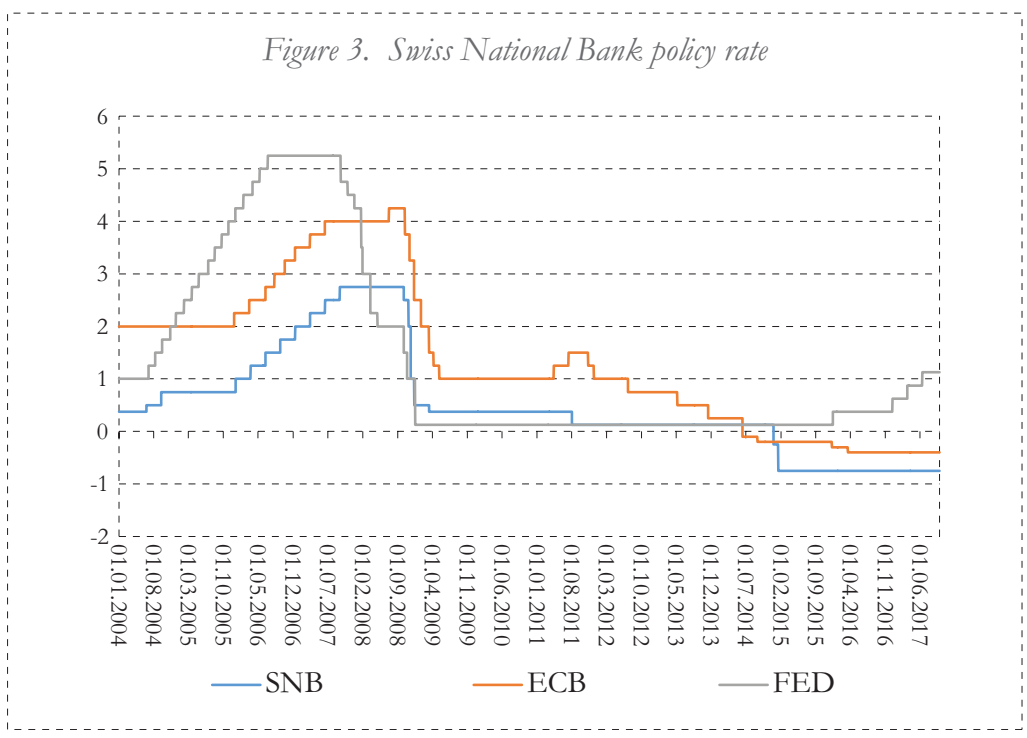


In Figure 3, you can see the policy rates of different central banks. As you can see, the Swiss National Bank lowered its policy rate quickly in the autumn of 2008, like the Fed and the ECB, and we reached zero in 2011. Given that in our case the policy rate is the three-month Swiss franc Libor, and not an overnight rate, the Swiss monetary policy stance is even somewhat more expansionary at a given policy rate relative to the Fed and the ECB. The ECB did not go all the way to zero at first, but it started to lower interest rates again in 2012, and finally it went negative in 2014. We waited longer, but lowered interest rates further, all the way to -0.75 percent.

By introducing negative interest rates, the Danish National Bank, the ECB, and the Swiss National Bank confirmed that the effective lower bound for monetary policy is below zero. However, this does not mean that there is no lower bound. The reason for such an effective lower bound is twofold, as pointed out by Ulrich: the existence of paper currency and bank profitability and, therefore, financial stability more broadly.

The existence of paper currency entails a risk of a run for paper currency because banknotes guarantee a zero nominal return, giving people an alternative to bank accounts or other financial assets with a negative nominal interest rate. At the same time, however, holding large amounts of paper currency is costly and inconvenient. At the time, when we lowered interest rates to -0.75 percent, the conventional wisdom was that it would not be possible to lower interest rates below 0.50 percent without risking a run on paper currency. So, it took a little courage to do it - and analysis. In particular, we figured out that insurance costs for paper currency are not easily scalable, because insurance companies put limits on how much cash they are ready to insure per unit, be it a safe or a vehicle. You cannot take a truck or a vault and fill it to the top with banknotes and get full insurance. The insurance company will only insure a certain amount per truck or vault. As a consequence, the costs for storage and insurance are higher than usually assumed. In addition, it is logistically and administratively cumbersome to store and handle large amounts of cash, as you have to deal with antimoney laundering regulation and so on. 
As to the concern about bank profitability, we took that into account when we designed our concept of negative interest rates with relatively large interest exemptions. In our case, as in the case of Denmark, negative interest rates were implemented to counter the appreciation pressure on the exchange rate. We figured out that what mattered for the transmission of the negative interest rates to money market was the interest rate, that is, the marginal rate that investors or banks have to pay for holding an additional Swiss franc, and not the total amount of interest that the banks have to pay on their sight deposits with the Swiss National Bank. Accordingly, we set a relatively high exemption threshold, which limited the financial burden for the banks while, at the same time, it made Swiss franc hoarding less attractive relative to other currencies. In order to determine the threshold for each bank, we took the minimum reserve requirement, and multiplied it by 20 . This was the most straight-forward way legally. Needless to say that not all banks were equally happy with this approach, especially banks with low minimum reserve requirements that had accumulated significant sight deposits with the Swiss National Bank during crisis.

Another feature of our negative interest rate concept was that we introduced a monthly adjustment for cash holdings. Banks have to report their cash holdings on a monthly basis as part of their minimum reserve requirement. We announced that if we registered an increase in cash holdings, adjusted for seasonal factors, we would reduce the amount of their sight deposits that was exempt from negative interest rates by the same amount. As a result, banks were indifferent between holding paper currency and holding sight deposits with a negative interest rate. This provided another disincentive for banks to exchange their bank deposits for paper currency, apart from the other costs of holding paper currency. 
Figure 4. Interest rate transmission

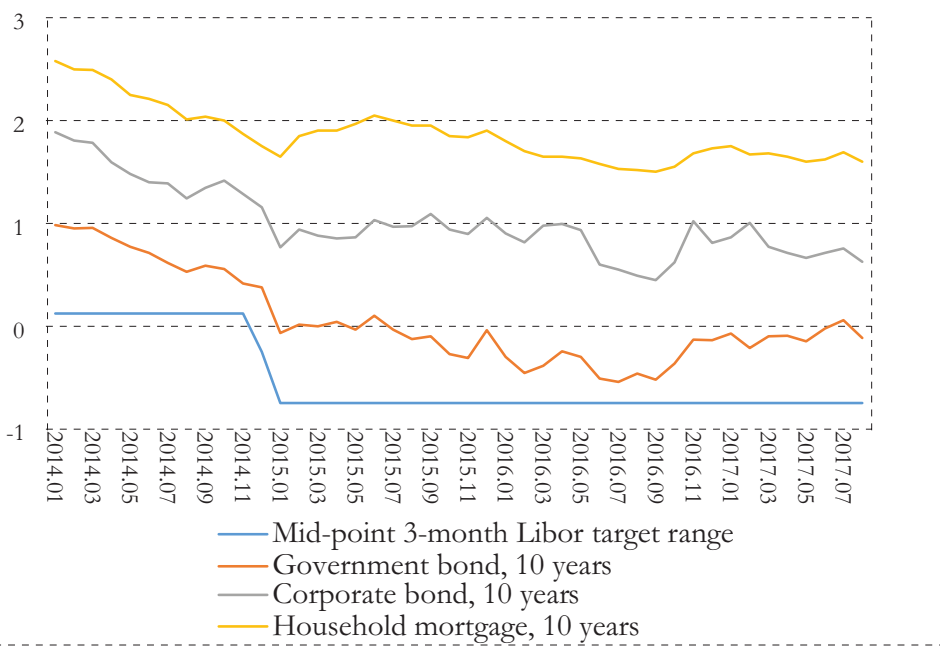

Now, let us turn to the transmission mechanism. Like the ECB, we saw an immediate transmission of our negative interest rate to the money market. Particularly, the three-month Swiss franc Libor moved in line with our deposit rate to -0.75 percent. As you can see in Figure 4, there was also a clear transmission to capital markets. Both government bond yields and corporate bond yields came down. The only interest rates that did not follow, and even increased somewhat after the introduction of negative interest rates, were mortgage rates. Our interpretation of this is that the banks - being reluctant to move deposit rates of their retail customers into negative territory increased mortgage rates to protect their interest rate margins. 
Figure 5. Interest rate transmission (2)

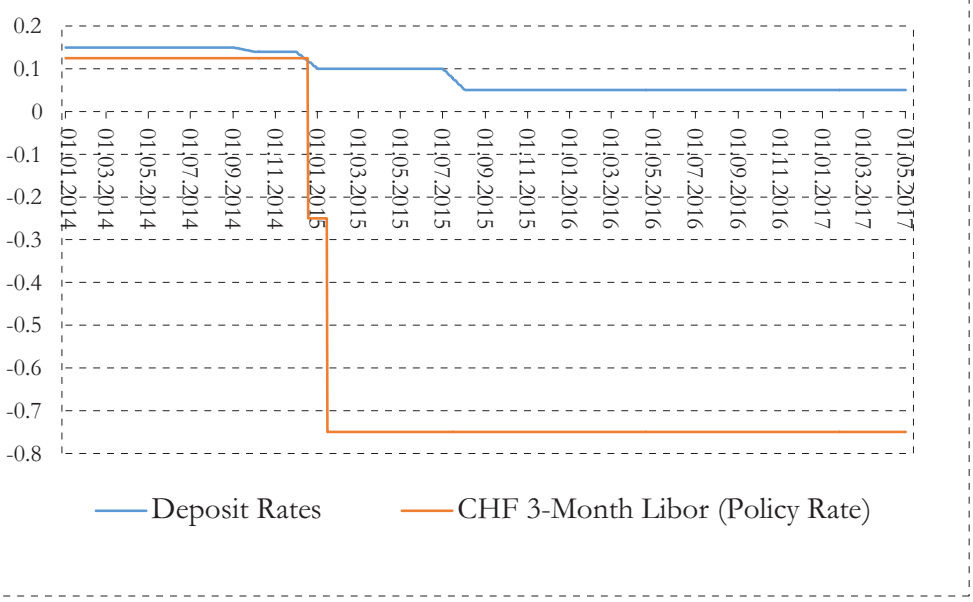

That banks did not pass on the negative interest rates to their retail depositors can be seen in Figure 5. We know that banks passed on negative interest rates to institutional investors, as well as to high net worth individuals, but always with a large exemption threshold. It seems that the banks were concerned that passing on negative interest rates to retail depositors could lead to a run on cash, given that it is less costly to store smaller amounts of cash. But a lot of smaller amounts of cash can still be a problem for banks.

Interestingly, we had one bank in Switzerland that passed negative interest rates on to their retail depositors. But that was a special case. It was the Alternative Bank Switzerland. It is a bank specialized in ethical and sustainable finance. According to them, they gained more new customers than they lost when they introduced negative interest rates for their retail depositors. Of course, it was all over the news when they announced the introduction of negative interest rates for retail depositors, and it seems that this extra publicity helped them to attract new customers who did not know about this bank before and who apparently valued certain ethical principles over profit maximization. This case can, thus, not be generalized. 
Figure 6. Mortgage rates, Libor swap rates, and mark-up

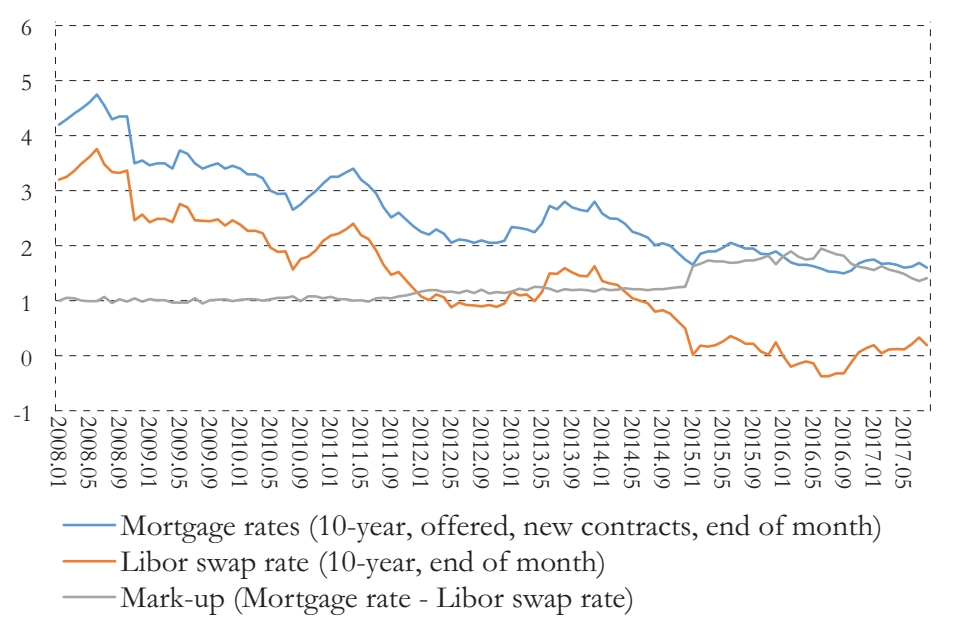

So, what did banks do if they could not pass negative interest rates on to their retail depositors? As noted before, it looks like they protected their interest rate margin by not lowering or even increasing mortgage rates. Figure 6 shows the 10 -year mortgage rate, which used to move parallel to the equivalent Libor swap rate, which gave the banks a constant margin. With the introduction of negative interest rates, that margin increased, as the mortgage rate was not lowered in line with the Libor swap rate. The fact that the mortgage rates did not fall further was not at all problematic in Switzerland, given that we were worried about the real estate market overheating. As I noted at the beginning, the problem in Switzerland was really the exchange rate and not a lack of domestic demand. So, the objective of negative interest rates in Switzerland was not the stimulation of the credit channel, but rather to make the exchange rate less attractive to safe haven flows.

What happened to the demand for paper currency when negative interest rates were introduced? Did we see increased demand? You may say that this is a special concern in Switzerland, given that we have a 1,000-franc note, a banknote with a very high denomination. As you can see in Figure 7, the growth rate for 1,000-franc banknotes in circulation increased with the introduction of negative interest 
Figure 7. CHF 1000 banknotes in circulation

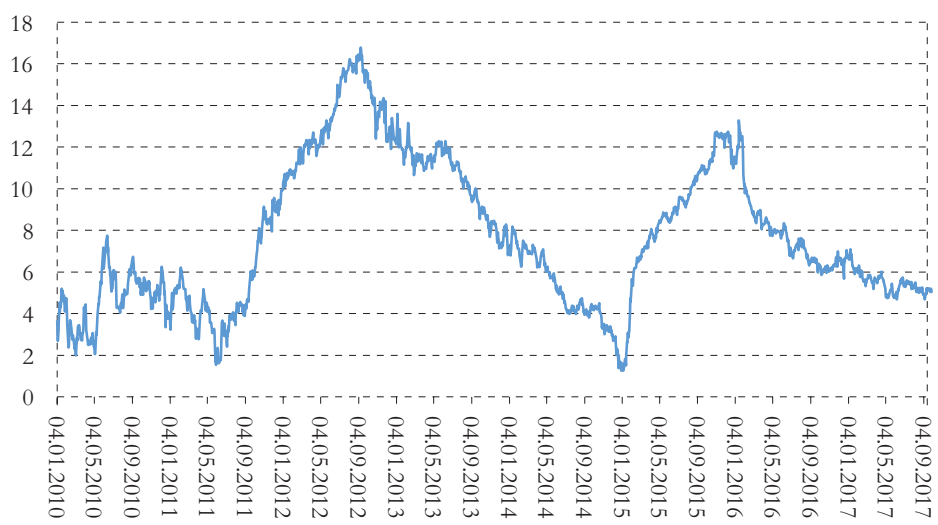

rates at the beginning of 2015. However, this increase was not unprecedented and therefore not unusual. We already saw a similar increase earlier in the crisis, namely in 2011, at the same time we saw an acceleration of the Swiss franc's appreciation. Moreover, the increase in demand for banknotes peaked in late 2015, at a lower level than in 2012, and it slowed down again afterward.

Figure 8. Government bonds $10 \mathrm{Y}$

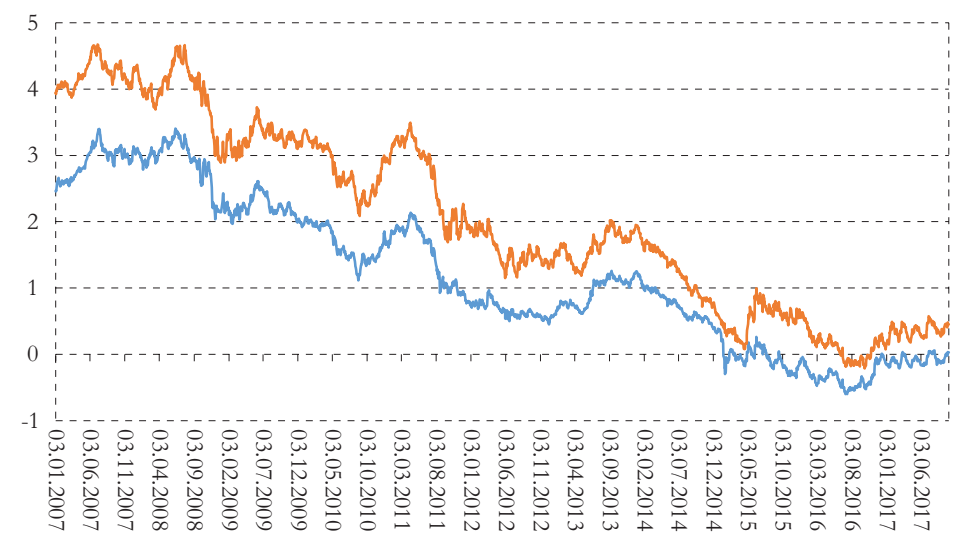

$-\mathrm{CH} \quad-$ Germany 
Switzerland's nominal interest rates are usually lower than nominal interest rates in the euro area, even lower than nominal interest rates in Germany. So, when all interest rates came down during the crisis, Switzerland's interest rates reached zero much earlier. Before we introduced negative interest rates, one of the problems that contributed to the appreciation pressure on the Swiss franc was that the traditional interest rate differential with the euro zone disappeared. As you can see in Figure 8, the introduction of negative interest rates at the beginning of 2015 helped to partially restore the historic interest rate differential with Germany. Since then, the interest rate differential decreased again, which is one of the reasons for the continued appreciation pressure on the Swiss franc.

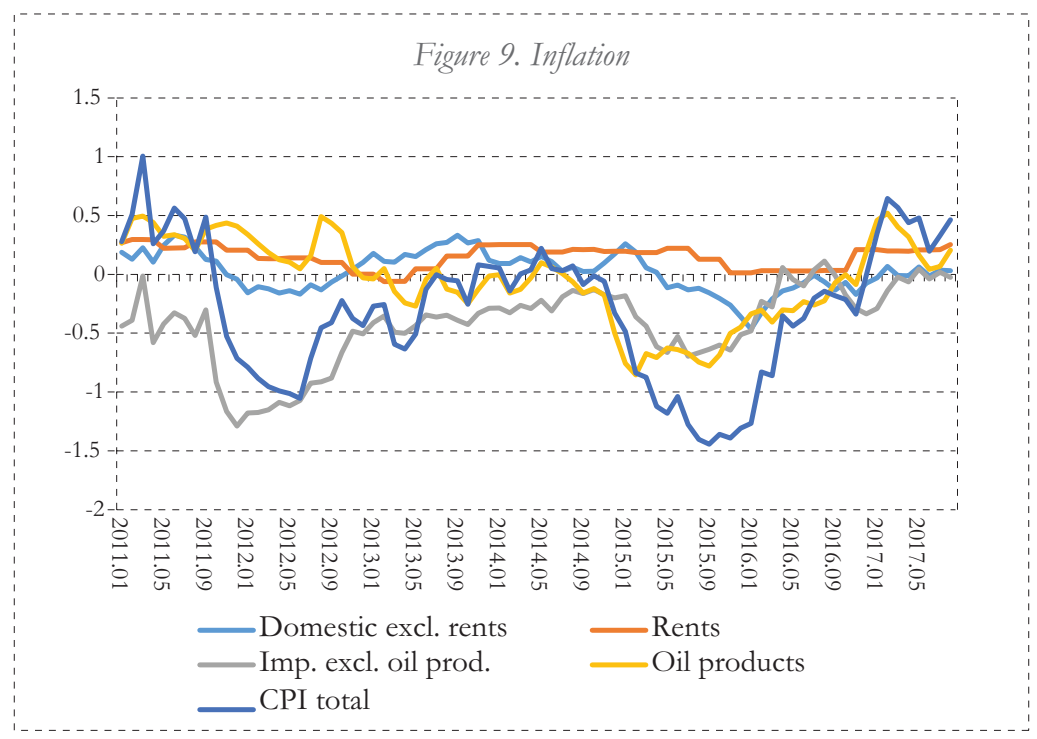

In terms of inflation, the ultimate objective of our monetary policy, you can see in Figure 9 that inflation in Switzerland was negative for several years since 2011. An expansionary monetary policy was therefore clearly necessary. Inflation has noticeably increased at the beginning of 2017, back into positive territory, partly aided by the increase in oil prices. 


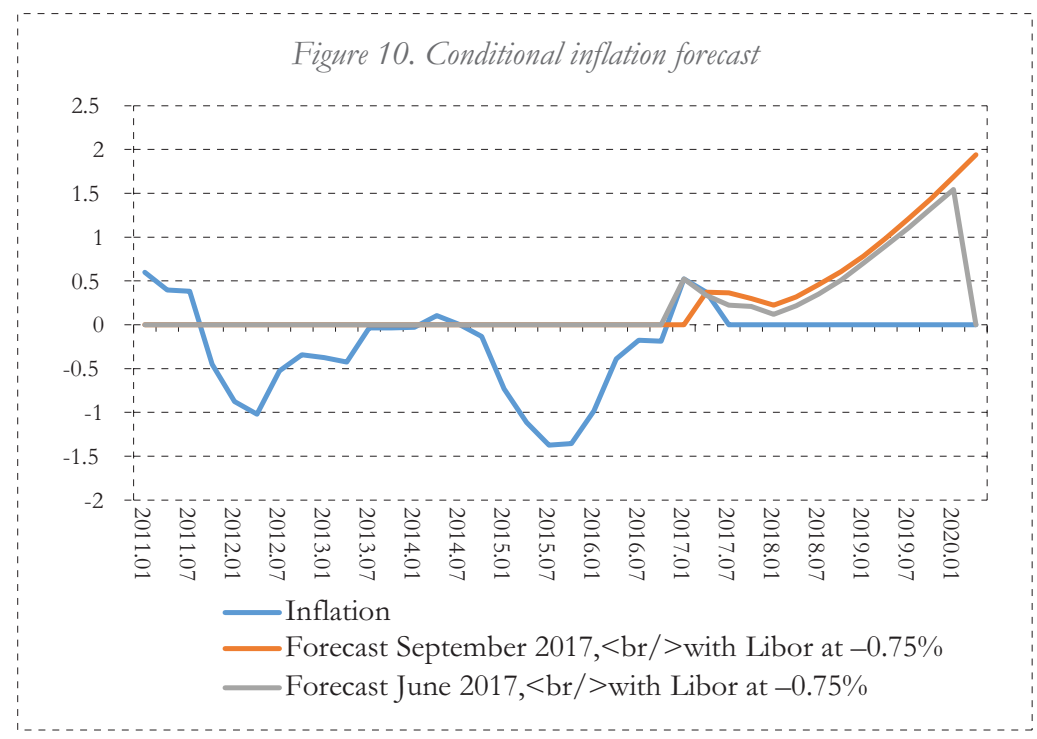

In Figure 10, you see our latest conditional inflation forecast. It is conditional in the sense that the policy rate is fixed at -0.75 percent throughout the entire period. Even at that interest rate level, there is no inflationary pressure visible. Our models suggest that price stability will be preserved even without a monetary policy tightening over the medium term.

The question going forward, therefore, is whether we have to get used to an environment with much lower nominal interest rates? Will negative interest rates stay with us or become a recurring feature over the coming years? If this is the case, we should be thinking about how to deal with the lower effective bound on nominal interest rates. If monetary policy below the zero lower bound is to become a regular occurrence, we need to be able to lower interest rates much further into negative territory than we have been able to do so far. This is something we should be working on now. 
MONETARY POLICY AND EXCHANGE RATE COMMITMENT IN THE CZECH

REPUBLIC

Dana Hajkova

Czech National Bank, Advisor to the Bank Board

\section{INTRODUCTION}

I would like to thank the Bank of Albania for inviting me to this conference, for the excellent organization and the very interesting content of this conference.

This morning, I will talk about the monetary policy experience of the Czech Republic and the influence and spillovers of our policy.

My presentation will be about the experience of the Czech National Bank (CNB) with the exchange rate as a further monetary policy instrument within the inflation target regime. I will start with the situation and the conditions for the implementation of this new tool, then evaluate its effects, and later I will discuss the exit from the exchange rate commitment, which actually happened quite recently.

\section{THE CONTEXT}

On the charts shown in Figure 1, you see depicted the economic situation we faced in November 2013, when the Czech economy was going through the longest recession in its history. As shown in the right chart, we had negative growth rates and a sluggish growth outlook. This was influenced by subdued external demand as well as by fiscal policy consolidation. The inflation outlook was also gloomy. By the end of 2012, the interest rates were at the zero lower bound, and for the $\mathrm{CNB}$, this bound was really binding. It was an effective lower bound at that time because we were facing some legal barriers to lowering interest rates to negative territory. It would 
have had negative consequences for the legal framework in the Czech Republic, and there was also a concern about its effectiveness because we would have expected cash hoarding and deposit outflows had interest rates been lowered below zero.

Figure 1. Context for implementation of FX commitment

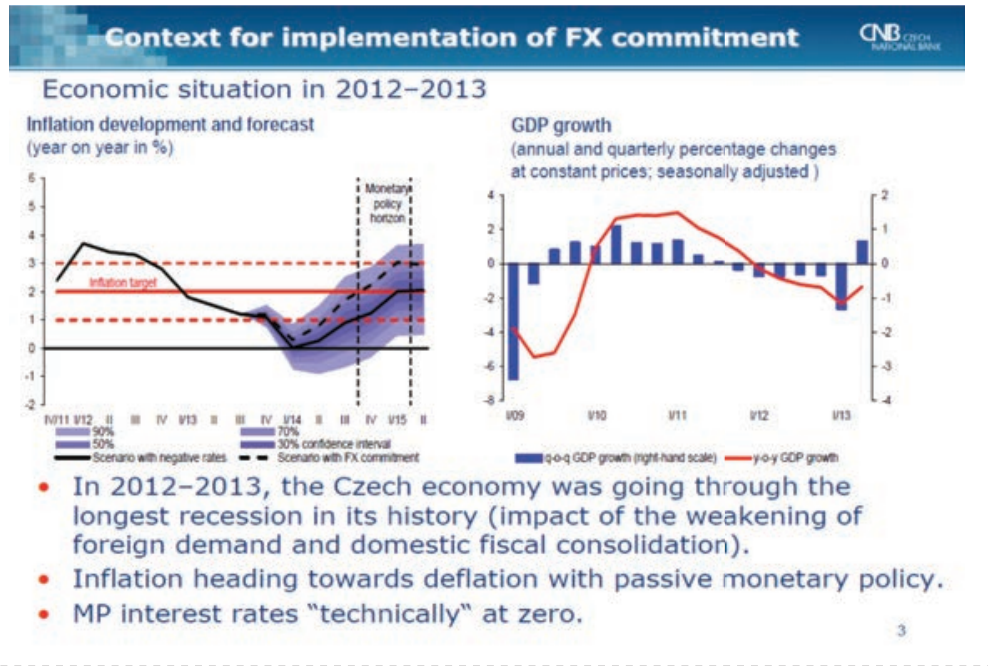

So, on the left hand side chart, you can see the inflation forecast at that point in time was conditional on two possible monetary policy options. Without monetary policy actions, we would have experienced deflation, with the inflation rate falling significantly below zero. The two policy options behind the forecasts were: (1) decreasing interest rates into negative territory, which the model was able to accomodate (unlike us in reality); and (2) the alternative tool, which was chosen, that is the exchange rate commitment.

You can see from Figure 1 that with the exchange rate commitment, we were forecasting inflation to revert to target within the monetary policy horizon, followed by a degree of overshooting for some time. 


\section{THE CNB FX COMMITMENT}

Figure 2. The CNB FX commitment

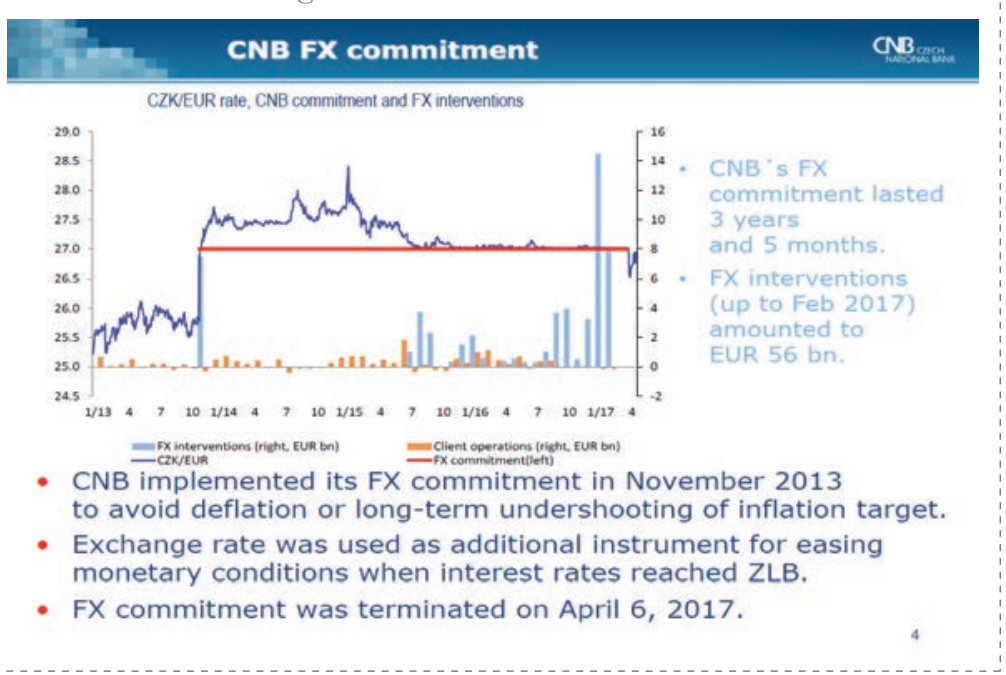

So what was the foreign exchange commitment of the CNB? The CNB introduced the exchange rate commitment in its policy meeting held in November 2013; it was an asymmetric commitment to maintain the Czech koruna exchange rate toward the euro at or above 27 korunas per euro.

On the weaker side, the CNB would let it fluctuate above the floor, but it would not let it appreciate below the floor. The main purpose of this floor was really to avoid deflation and long-time undershooting of the inflation target. Developments in the real economy of the Czech Republic motivated the adoption of this policy option. This is, therefore, slightly different from the motivations in Switzerland.

The exchange rate was used as an additional tool within the framework of inflation targeting. We remained inflation targeters; we didn't want to change the monetary policy regime. As we were at the zero lower bound, we had to think of additional tools to ease monetary policy conditions to prevent the negative consequences for the Czech economy, which would have resulted from a widening output gap and a disanchoring of inflation expectations. 
All in all, the CNB commitment lasted for three years and five months and it ended on April 6, 2017, just one month ago. You can see how the exchange rate developed during the commitment in Figure 2. The exchange rate adjusted quite fast, immediately after the introduction of the exchange rate commitment. It even remained above the floor for more than one year. Hence, there was no need for the Czech National Bank to intervene in the financial markets, except for the first days, as shown by the blue bars in the chart of Figure 2. Initial interventions necessary to enforce the commitment actually saved any further interventions, as the market had confidence in the CNB's willingness and ability to enforce the commitment.

Interventions resumed in May 2015. Appreciation pressures reemerged as a result of speculation about the timing of a possible exit from the exchange rate commitment, which also fueled FX hedging from exporters, and the initial effects of further ECB monetary policy accommodation, which stimulated further capital inflows.

The intervention activity intensified in the second half of 2016 and the beginning of 2017, as the financial markets perceived that the inflation outlook was improving and they were speculating that the CNB could terminate its foreign exchange commitment any time soon. Thus, there was a lot of speculation on suspected exchange appreciation after the upcoming exit from the foreign exchange commitment regime.

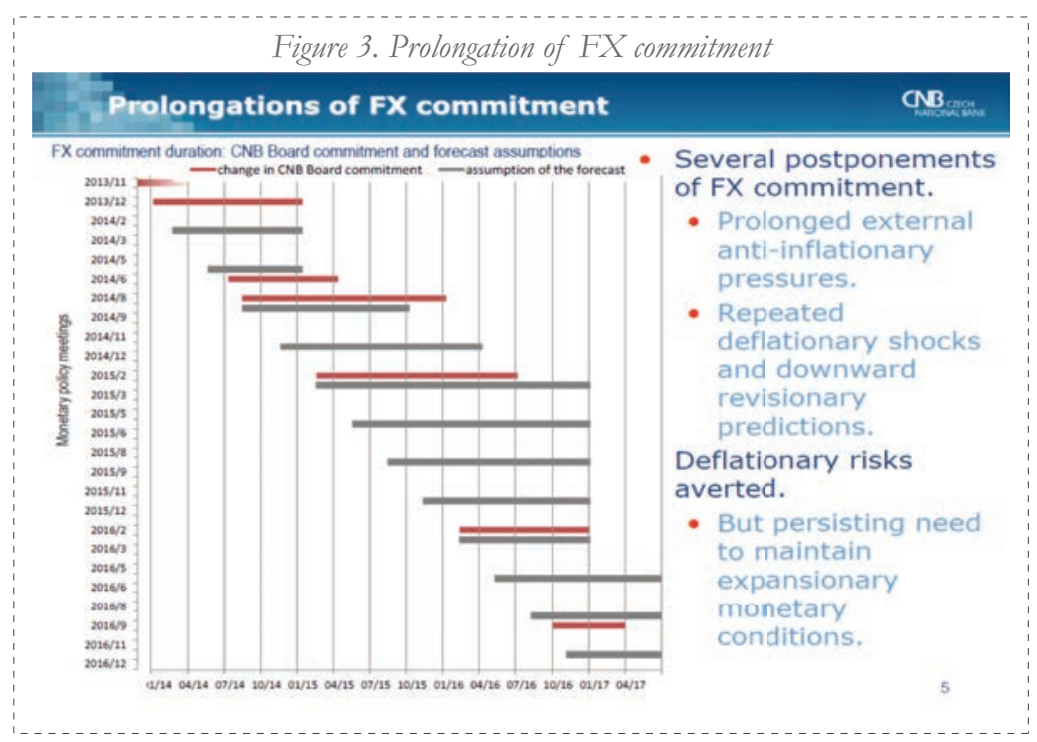


All in all, the interventions amounted to EUR 56 billion up to February 2017; these are the last published data. But we already know that by the end of March 2017, almost at the end of the exchange rate commitment, the foreign exchange reserve of the Czech National Bank increased to 70 percent of GDP. Therefore, in this period, we accumulated a sizeable amount of FX reserves.

The length of the exchange rate commitment was initially not stated, but it was almost immediately obvious that it was important to give the real economy some kind of guidance on the length or duration of the exchange rate commitment. Therefore, the CNB bank board started to guide markets and say what was the expected minimum duration of the foreign exchange commitment. This was called in our slang the "hard" commitment, which was really perceived as an almost irrevocable commitment of the CNB to keep the exchange rate commitment for the minimum period indicated. This is shown in Figure 3. These are the red bars in the figure, and you can see they appeared almost immediately after the entry of the foreign exchange rate commitment into effect.

The duration was initially stated to last until the end of 2014. Then, after eight months, it was prolonged to the end of 2015, and then it was prolonged three times, again and finally, in September 2016, when it was prolonged until March 2017. The gray bars in the chart of Figure 3 show the assumption of the CNB official economic forecast. The economic forecast had to work with some assumptions about how the monetary policy would work to facilitate a gradual return of inflation to target. Therefore, you can see that these forecast assumptions more or less coincided with what the bank board externally communicated.

The prolongations of the exchange rate commitment were driven by the repeated disinflationary surprises or shocks, which we were all facing in Europe with declining producer prices. These shocks led to multiple revisions in the pace and timing of convergence of inflation to target. All forecasters in Europe were facing the same issues: the inflation rates were depressed, there were downward revisions in the inflation forecasts, and subdued underlying inflation pressures. As the Czech economy "imports" a lot of inflation from Europe, this 
was also the problem of the Czech economy, but we can say that deflation risks in the Czech Republic were averted.

\section{EFFECTS OF THE EXCHANGE RATE COMMITMENT}

Figure 4. Effects of the exchange rate commitment on Czech economy

Effect of exchange rate commitment
on Czech economy

- Monetary easing significantly contributed to renewal of economic growth in 2014.

- Other significant growth contributors were external recovery and resumption of investment activity financed by EU funds.

\begin{tabular}{|l|c|c|c|}
\hline & $\mathbf{2 0 1 3}$ & $\mathbf{2 0 1 4}$ & $\mathbf{2 0 1 5}$ \\
\hline GDP & $-\mathbf{0 . 5 \%}$ & $\mathbf{2 . 7 \%}$ & $\mathbf{4 . 6 \%}$ \\
\hline Gross value added & $-0.5 \%$ & $3.4 \%$ & $3.9 \%$ \\
\hline Contribution of individual factors to the GDP dynamics \\
\hline fiscal impulse & -1.0 p.p. & 0.3 p.p. & 0.8 p.p. \\
\hline growth in effective EA & 0.6 p.p. & 1.1 p.p. & 1.9 p.p. \\
\hline oil price & 0.0 p.p. & 0.1 p.p. & 0.7 p.p. \\
\hline tobacco excise duties & 0.0 p.p. & -0.7 p.p. & 0.7 p.p. \\
\hline monetary pol. + sentiment & $-\mathbf{0 . 1}$ p.p. & 1.9 p.p. & 0.5 p.p. \\
\hline
\end{tabular}

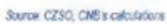

We tried to evaluate the effects of the exchange rate commitment in the Czech economy. The estimated effects on economic growth are in the first line of the table shown in Figure 4. We can see that in 2014 - the first year after the introduction of the commitment - the economic growth was 2.7 percent. We were facing some positive contributions from growth in the euro area, about 1 percentage point, but a real significant contribution, almost 2 percentage points, was estimated due to monetary policy and its effects on the economy. In the same table, you can also see that there is an effect of fiscal policy on GDP growth amount, for example, to 1 percentage point in 2013. 
- Negative MP rates in numerous economies.

- ECB Asset purchase programmes.

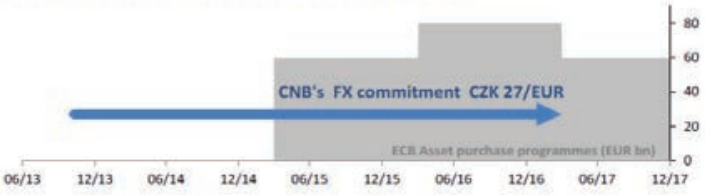

- Large amounts of capital searching for yield.

- Intervention activity of CNB influenced by real economy needs and by inflow of international liquidity.

In the international context, the most important effects from the ECB monetary policy on the Czech monetary policy were the interest rate differential, as well as capital and liquidity flows from the euro area, as a consequence of the large supply of liquidity and the lower yields of financial assets. In Figure 5, you can see the length of the exchange rate commitment in the context of ECB asset purchase programs. What the CNB faced was the inflow of money from international investors, who were searching for yield. There was interest rate differential on Czech assets, though government bond yields in the Czech Republic also went deeply negative. We had negative yields up to six years of maturity, and there was important speculations also on the appreciation of the currency.

The intervention activity of the Czech National Bank was influenced by this and also naturally by the inflow of the money from real economy activities from net exports, and also from hedging activity of the exporters.

The CNB has always repeated that the intervention and its balancesheet consequences are not important because the primary objective of the $\mathrm{CNB}$ is to achieve the inflation target, and the profit consequences, which will come later, are secondary to this goal. 


\section{THE EXIT}

Figure 6. Exit from the FX commitment

\section{Exit from the FX commitment}

- Economic conditions were met:

- Sustainable fulfillment of the $2 \%$ target.

- No need to revert to unconventional policy measures.

- Form:

- Transparent one-off termination.

- Managed-float regime employed.

- Subsequent development of FX

- Sharp appreciation not expected and did not materialize.

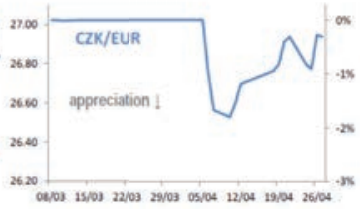

- Weaker exchange rate has transmitted to nominal variables + slower real equilibrium appreciation.

- Large speculative inflows before end of commitment = missing counterparty.

- No excessive volatility so far.

What about the exit? The exit came when the economic conditions - which were stipulated before - were met: this was a sustainable fulfillment of the 2 percent inflation target. Inflation has reached 2 percent already before the end of 2016, and during the first months of 2017 we are above 2 percent. This is partially the result of some transitory, one-off effects including the effect of oil price developments, some administrative effects, and also the development of food prices, but we are pretty confident about the robustness of inflationary developments because core inflation in Czech Republic is comfortably at 2 percent and inflation pressures in the domestic economy are quite strong and robust.

The exit from the exchange rate commitment took place as a transparent one-off termination: at a regular meeting of the bank board, which was initially not scheduled as a monetary policy meeting, but turned into a monetary policy meeting. This meeting was the first meeting of the bank board after the end of commitment at the end of March 2017. It was said that the managed float regime would be employed, but the CNB would be ready to observe or manage large volatility that might come. It was not specified what kind of volatility this was going to be, because some volatility was to 
be expected; we would only go to market if volatility was excessive.

What actually happened is depicted on the chart of Figure 6. You can see that there was some appreciation, but it was really mild, less than 2 percent at the maximum and now the exchange rate is even weaker again.

The data in the chart are until Friday on April 28, 2007. At that point, we are at around $26.8 \mathrm{CZK} / \mathrm{EUR}$, so still slightly below the $27 \mathrm{CZK} / \mathrm{EUR}$ former floor, as shown on the chart. No massive appreciation took place. It was not expected by us, for several reasons. We thought that a weaker exchange rate would transmit to nominal variables so there would be less pressure to appreciate and also that the real equilibrium appreciation would be slower than before the economic crisis: about 1 to 2 percentage points per year.

An important consideration was that there were large speculative positions built in Czech koruna and that investors were actually waiting to realize their profits from their positions. These investors would take any profitable opportunity to go out of Czech currency. They would, hence, provide depreciation pressures that would limit the appreciation tendency.

In summary, the Czech National Bank has successfully used exchange rate as a monetary policy tool, and we kept our inflation target regime. We averted the risk of deflation. Because of repeated anti-inflationary shocks, we had to prolong the exchange rate commitment several times. It was finally terminated after three and a half years, but the exit has been so far quite smooth, and no excessive FX volatility has so far appeared. In 2017, our outlook is for a sustainable fulfillment of the inflation target. Our most recent inflation outlook indicates some overshooting of the point inflation target of 2 percent in the coming year, but we are going to be around $2.6-2.7$ percent, and go back to the inflation target within the monetary policy horizon in 2018. 
This page intentionally left blank 


\section{NON-STANDARD MONETARY POLICY IN A LOW INTEREST RATE ENVIRONMENT}

Daniel Felcser

Magyar Nemzeti Bank, Monetary Strategy Department, Senior Economic Analyst

Thank you very much for the opportunity to talk about the Hungarian experience. It comes with the usual disclaimer about the views expressed here. Let's phrase it in the way that I am analyzing and advising policy, but not making it, unlike some of the participants here. A one-line catchy title would be the Hungarian way, but I chose a somewhat longer one, connecting the title of the presentation and the topic of the conference.

I would like to highlight two important factors, among others, behind the Hungarian monetary policy developments. The first one is the conversion of household FX loans into Hungarian forint in late 2014, which removed the major systemic financial risk from the balance sheets and substantially reduced the FX exposure of the households

Figure 1. Monetary policy and balance sheet

\section{The MNB has eased monetary conditions} while reducing its balance sheet

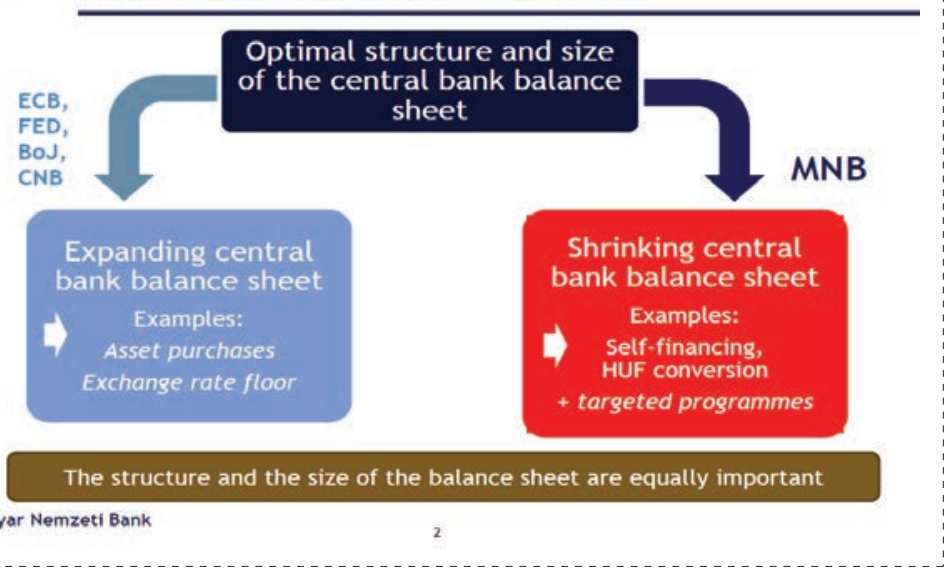


and also of the whole economy. The second one is ECB's monetary policy. As it appears in our statements, the eurozone's monetary policy conditions are highly relevant for Hungary. We have not only been facing accommodative external environment in terms of monetary conditions, but they are also expected to be maintained for a considerable period.

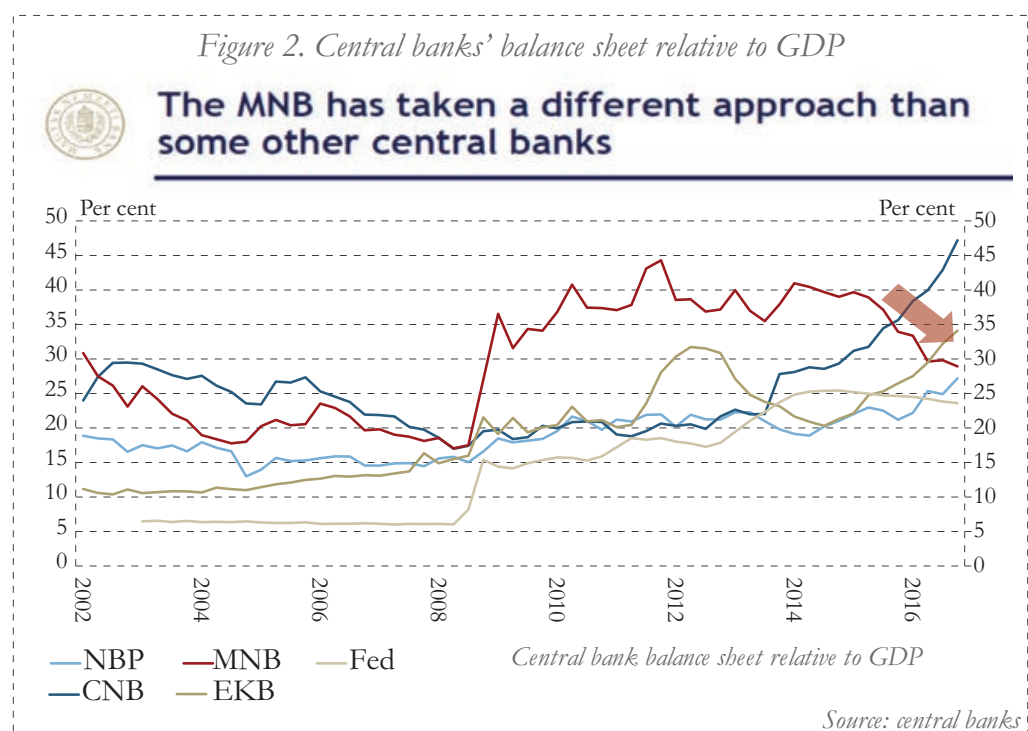

Nevertheless, the Central Bank of Hungary has taken a different approach compared to other central banks in recent years, and has eased its monetary conditions while reducing its balance sheet as shown in Figure 1. Looking at Figure 2, we can see the evolution of balance sheets of some central banks, major central banks, and the central banks of the Central European region.

We can see that the lines representing the Central Bank of Hungary and the European Central Bank balance the sheet's size as a percentage of the GDP intersect around the middle of 2016. The two lines cross each other, and the Hungarian balance sheet has continued to decrease ever since. 
Figure 3. MNB recent monetary policy measures

\section{Overview of recent traditional and} unconventional monetary policy measures

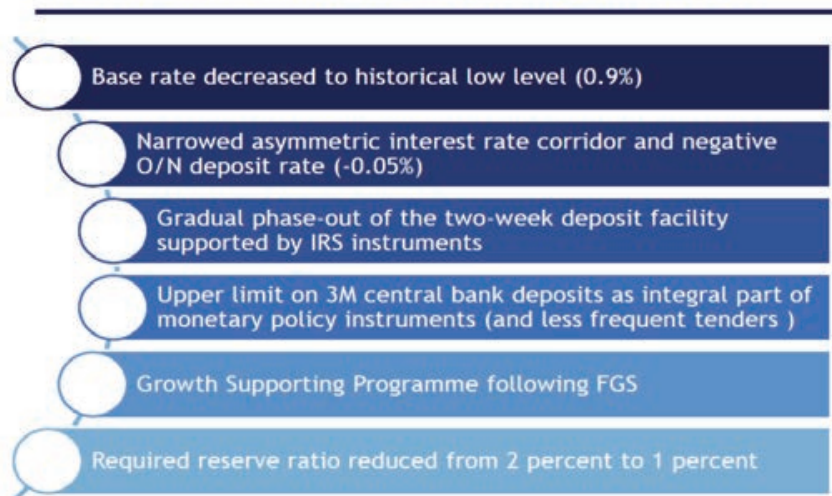

Magyar Nemzeti Bank

Let me briefly talk about some monetary policy measures, either conventional or unconventional in nature, that have enabled us to conduct loose monetary policy with a shrinking balance sheet. They are summarized in Figure 3. These steps are related to the base rate, the interest rate corridor, the main policy instrument, and the limitation of that, our lending incentive program and a decline in the

Figure 4. MNB base rate and expectations

\section{After a long easing cycle, the MNB maintains the current base rate for an extended period}

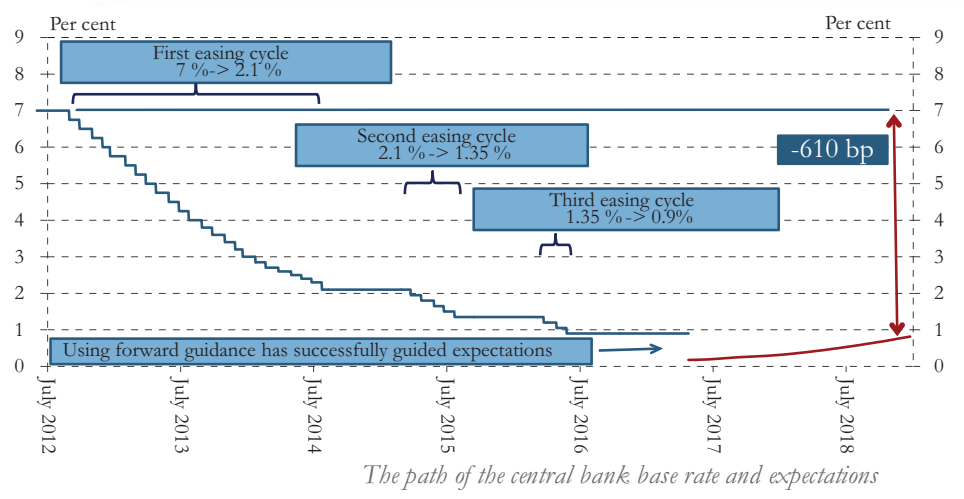

Magyar Nemzeti Bank 
required reserve ratio. I will touch upon each of these, except for the last one.

Let me start with the base rate. Starting in the summer of 2012, the main policy rate has been cut by a total of 6.1 percentage points, in order to achieve our inflation target; meanwhile, an inflation tolerance band was introduced to ensure larger flexibility in case of inflationary shocks. More recently, in the third phase, the base rate was cut by 45 basis points to the new historical low level of 0.9 percent.

In the three consecutive steps from March of 2016 to May 2015, the Council also stated as before its intention to maintain the current level of the base rate and loose monetary conditions for an extended period of time as long as it is consistent with the achievement of the central bank's objectives. We also see that market expectations or implied yield curves indicate a low interest rate path for a prolonged period. So, in this sense, forward guidance has successfully oriented expectations in Hungary.

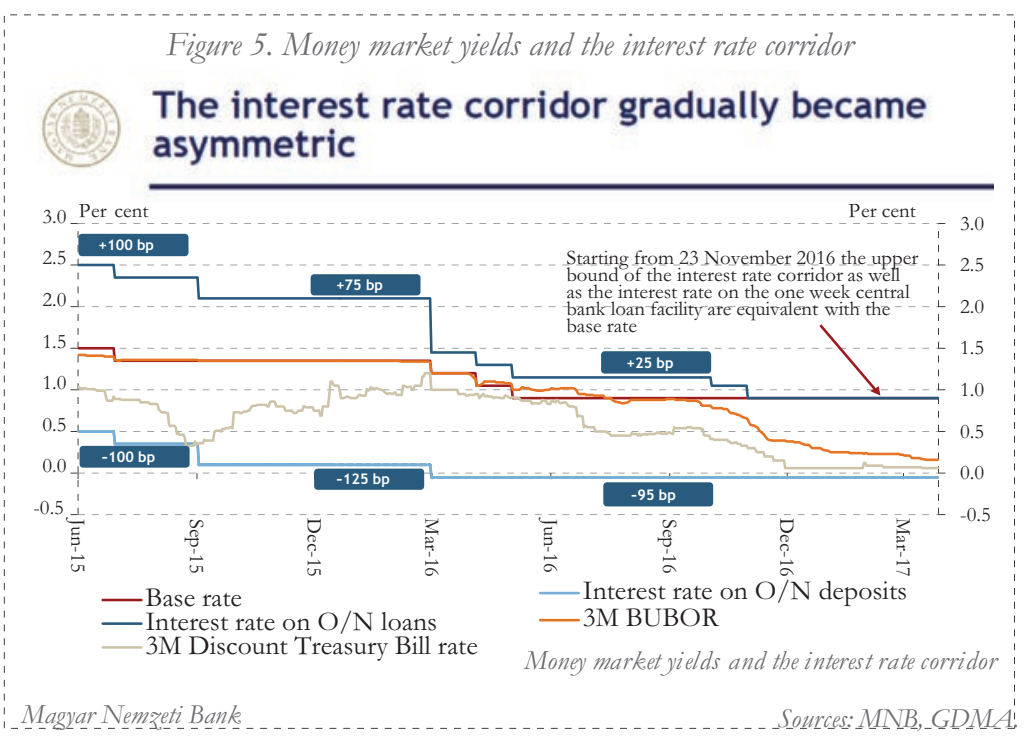

The interest rate corridor around the base rate used to be symmetric with a plus/minus 100 basis point range. First, it was shifted by 25 basis points in 2015. Then, the overnight deposit rate was cut to a 
slightly negative level - to -0.05 percent - simultaneously with the base rate cut in March 2016. Afterward, the upper bound of the corridor declined in several steps until it reached the same level as of the base rate. With the asymmetry of the interest rate corridor, the bank aimed at avoiding a possible increase in the short-term interest rate volatility stemming from the declining liquidity of the system, and, at the same time, managed a decrease in the average overnight interest rate level.

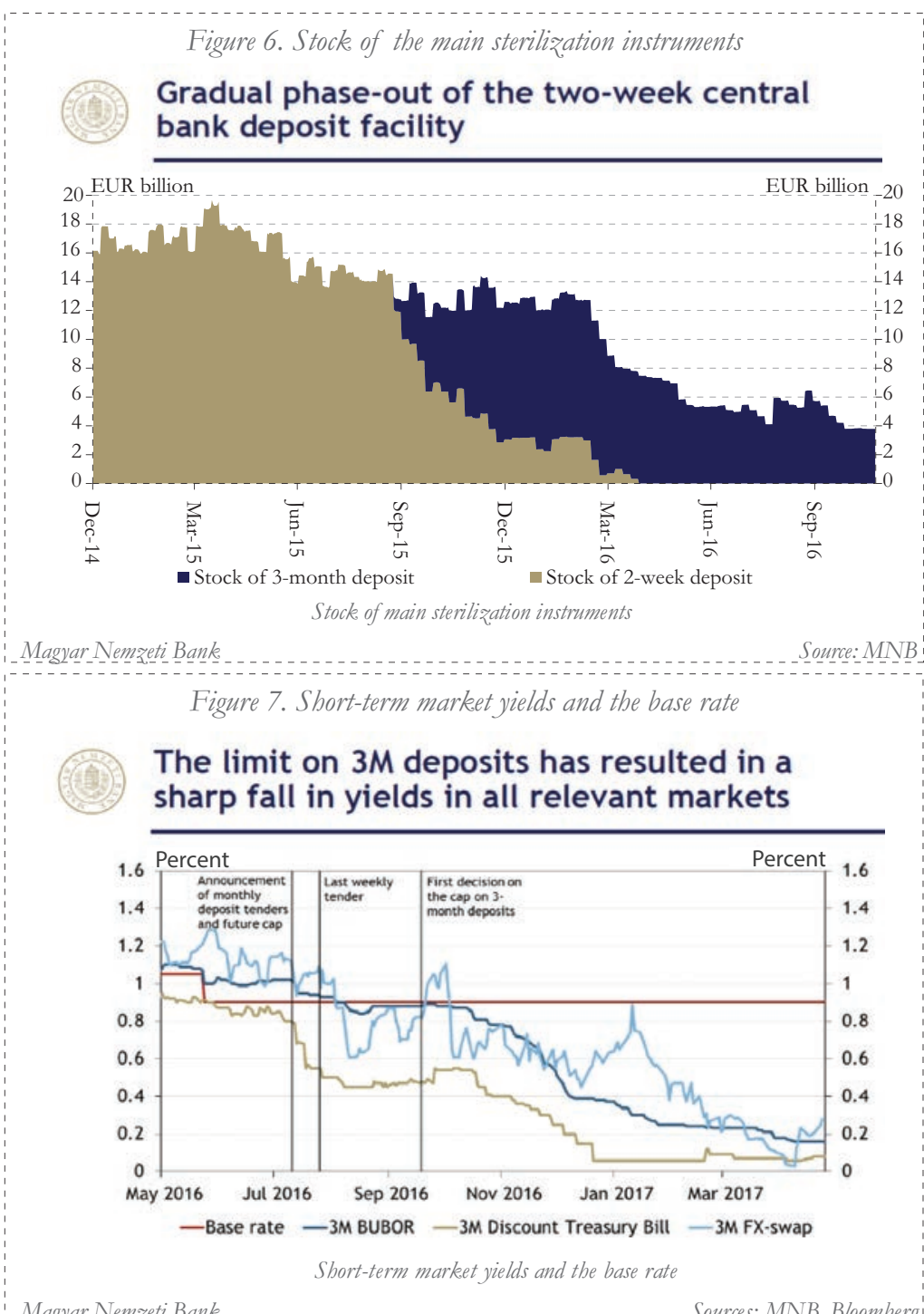


Besides, after the previous introduction of the three-month deposit facility and limiting the volume of the two-week facility, in January 2016, the Council decided to gradually phase out the two-week deposit facility. Moreover, in July 2016, the Bank announced that first from August 2016 the three-month deposit tender would be announced once a month instead of the former weekly frequency and also from October 2016 the Bank would limit the amount of banks' bids accepted at the tender.

Following the announcement, in September 2016, a HUF 900 billion upper limit on the three-month deposit stock was announced to be met at the end of the fourth quarter of 2016. This quantitative restriction crowds the liquidity out from the main deposit facility. If you look at this framework, exhibited in Figure 8, the liquidity is "looking for its place" in the interbank market and is accumulated in another central bank deposit, facility with lower interest rates. This can be preferential deposit which is also a limited instrument available for banks, which have made a commitment for their net lending activity to be positive in a certain period, or it can be overnight deposit, which now has a slightly negative interest rate.

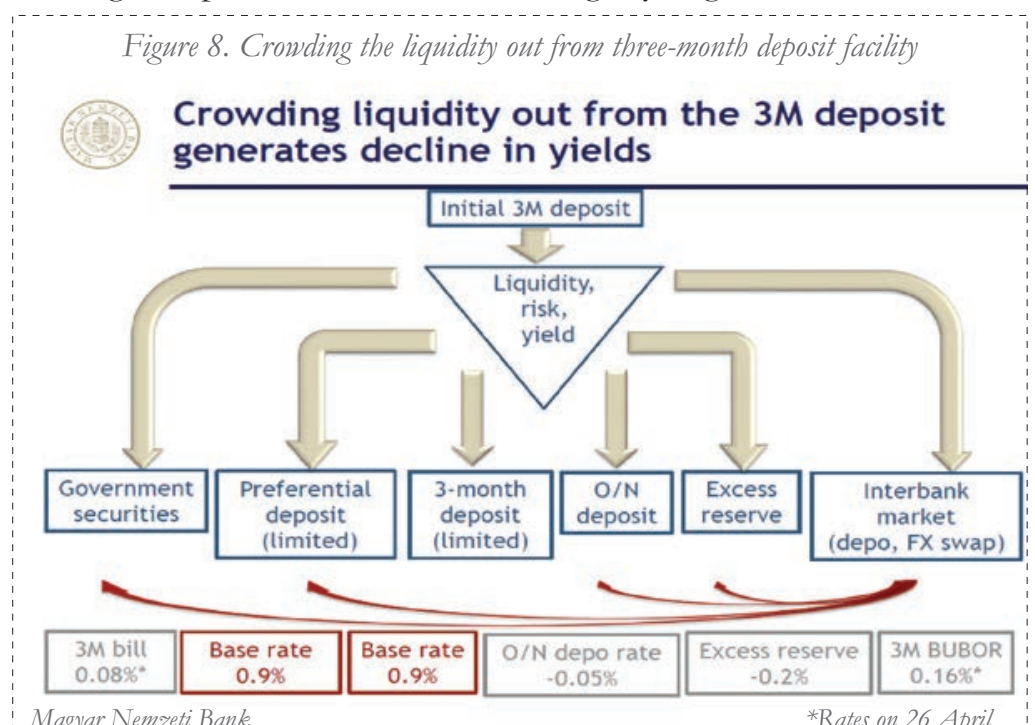

The liquidity can present itself in excess reserves, but the interest rate here is the overnight deposit rate minus 15 basis points. Or banks 
may choose to place liquidity in some securities with preferably longer maturities, which can be used later as collateral. Due to the characteristics of the Hungarian financial markets, these securities are typically government papers, such as treasury bills, and bonds. If we go back, this cap on the three-month deposit is now considered as an integral part of the monetary policy toolkit, and it is set quarterly. In December, it was lowered to 750 billion, and last time it marched across the 500 billion bound, as at the end of the second quarter of 2017, to preserve the amount of the liquidity crowded out of the deposit facility previously and thereby maintaining the loose monetary conditions achieved. This last decrease was mainly motivated by the decline in the banking sector liquidity compared to the previous quarter due to some autonomous liquidity factors and not by an additional monetary easing as before.

Overall, we can see that this limit has resulted in a sharp fall in yields in all relevant markets, as the central bank aims to ease monetary conditions through a decline in money market rates. The Bank also introduced fine-tuning instruments to offset potential liquidity shocks, so it is a quite complex process: we need forecasts for the banking sector liquidity to be able to carefully set these caps on the deposit facility.

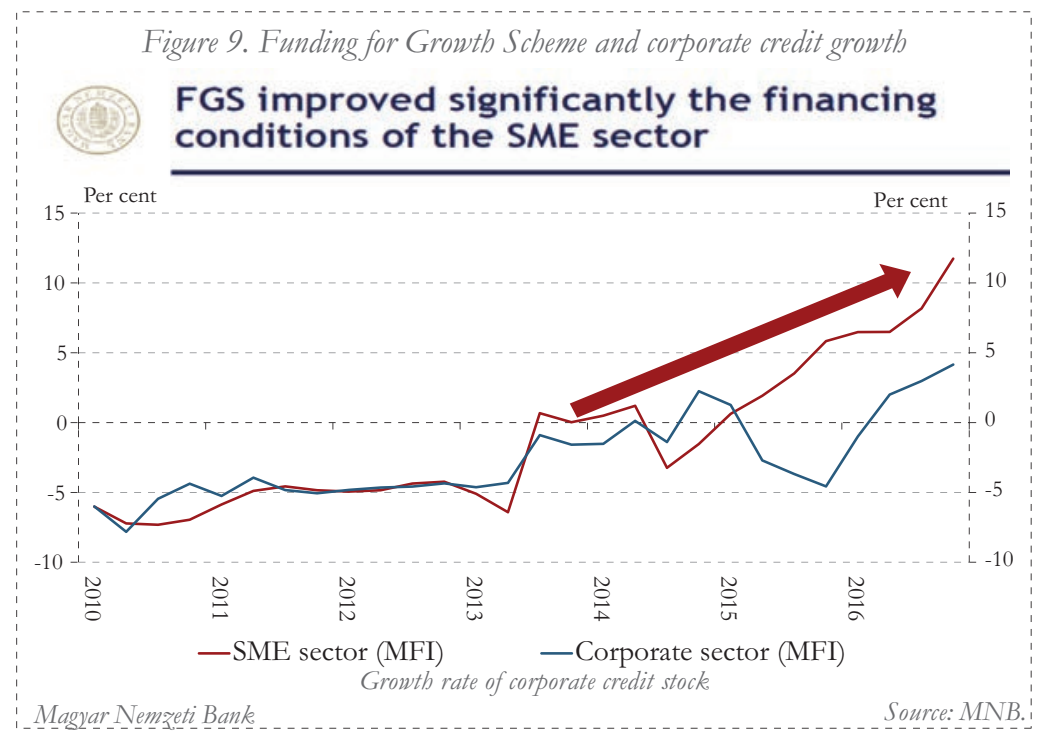


And, finally, we had a lending incentive program started in 2013, which ended in March this year. Banks received financing from the central bank, and they lent it with a maximum of 2.5 percent margin. Overall, throughout the program, over 36,000 enterprises received funding, amounting to more than 2,400 billion Hungarian forints, which are equivalent to approximately 8 billion euro and a little above 7 percent of GDP.

As a result, the growth rate of corporate credit stock has returned to the 5-10 percent band, which is the preferred annual growth rate by the central bank. This is evidenced by Figure 9. After the Funding for Growth Scheme (FGS) is phased out in March, the transition to lending under market conditions will be assisted by the Bank's Market-Based Lending Scheme. It is part of the Growth Supporting Programme of the Bank. It mainly provides some positive incentives for the banks to continue lending to SMEs under market conditions as well.

To sum up, the Central Bank of Hungary stopped the rate cut cycle last year, but has eased monetary conditions further. Now inflation is expected to reach the target in a sustainable manner in the first half of 2018, while economic growth has picked up and vulnerability of the country has decreased at the same time. 
This page intentionally left blank 
This page intentionally left blank 


\section{SIXTH SESSION: NEGATIVE EURO AREA INTEREST RATES AND MONETARY POLICY IN THE WESTERN BALKANS}

Moderator: Erald Themeli Bank of Albania, Monetary Policy Department, Director 
This page intentionally left blank 


\section{SPILLOVERS OF THE ECB'S NON STANDARD MONETARY POLICY MEASURES ON SOUTHEASTERN EUROPE ${ }^{1}$}

Keynote address: Isabella Moder European Central Bank, Economist

\section{INTRODUCTION AND MOTIVATION}

"International spillovers from the monetary policy of one country to other economies are a corollary of globalisation. This entails that we, as policymakers, have to rise to the challenge of conducting monetary policy in the presence of these unintended side-effects. $[\ldots]$ We should not underestimate the challenges of living in the ever more closely interconnected global economy."

Vítor Constâncio, Vice President of the ECB, Hong Kong, 15 October $2015^{2}$

Over the past years, there has been a discussion in academia and among policymakers on the international effects (that is, spillovers) of advanced economies' standard and in particular non-standard monetary policy in response to the global financial crisis and its legacy. Originally, the focus of interest was spillovers originating from the Federal Reserve's monetary policy, but more recently the international effects of the European Central Bank's (ECB) standard and non-standard monetary policy measures have gained increased attention. Since August 2007, and, in particular after October 2008, the ECB has introduced a number of non-standard monetary policy measures, which are unprecedented in nature, scope, and magnitude; and have included significant changes in the operational framework and large bond purchasing programs.

This contribution is based on Moder, I. (2017), "Spillovers of the ECB's non-standard monetary" policy measures on Southeastern Europe," ECB Working Paper No 2095, Frankfurt am Main. The viens expressed are those of the author and do not necessarily reflect those of the ECB or of the ESCB.

2 The full speech can be accessed under: http:/ / wmm.ecb.europa.eu/press/ key/date/ 2015/ html/ sp151015.en.html 
Spillovers from the ECB's non-standard monetary policy on Southeastern Europe (SEE) are particularly relevant because the SEE countries are located in the direct neighborhood of the euro area and are already EU members (Bulgaria, Croatia, and Romania) or have the prospect of joining the EU in the future (Albania, Bosnia and Herzegovina, the Former Yugoslav Republic of Macedonia, Montenegro, and Serbia ${ }^{3}$ ). Moreover, the economies of the SEE countries are closely interlinked with the euro area through several channels that could potentially transmit euro area monetary policy shocks: first, the significant presence of euro-area-headquartered banks and a high degree of euroization constitute a financial or banking transmission channel of monetary policy shocks. Second, high trade integration and sizeable remittances flows could act as real channels for shock transmission.

Additionally, the heterogeneous monetary policy frameworks and exchange rate regimes of SEE countries provide an interesting case for cross-country comparisons with regard to the role of exchange rate regimes in shaping spillovers: in SEE they range from inflation targeters with (managed) floating exchange rates (Albania, Romania, and Serbia), via stabilized arrangements with the euro as a reference currency (Croatia and the former Yugoslav Republic of Macedonia) and eurobased currency boards (Bosnia and Herzegovina and Bulgaria) to the unilateral adoption of the euro as the sole legal tender (Montenegro).

\section{A FRAMEWORK FOR ESTIMATING SPILLOVERS}

A major challenge for estimating spillovers of non-standard monetary policy is the measurement of the degree of monetary accommodation provided through non-standard monetary policy measures, since they are typically not captured by the key monetary policy rate. Therefore, alternative indicators have to be found.

For the purpose of estimating spillovers from the ECB's nonstandard monetary policy measures on SEE, I mostly resort to the size of the Eurosystem balance sheet, which mirrors the liquidity provision of the Eurosystem and, thus, reflects most non-standard

While the potential EU candidate Kosovo* is also located in SEE, it cannot be included in the analysis due to limited data availability. *This designation is without prejudice to positions on status and is in line with UNSCR 1244 and with the ICJ Opinion on the Kosovo Declaration of Independence. 
monetary policy measures that were introduced by the ECB. The Eurosystem balance sheet assets started to increase notably with the introduction of non-standard monetary policy measures in October 2008, and, thereafter increased further significantly as a result of the various instruments used, with some variations over time owed to their nature and set up (Figure 1).

In order to be able to compare the spillovers across the SEE countries, a separate structural Bayesian Vector Autoregressive (BVAR) model is estimated for each country. Each model includes a number of euro area variables (output, price level, Eurosystem balance sheet assets, a measure of financial stress, the spread between the EONIA and the key monetary policy rate, and the key monetary policy rate as a separate variable) and SEE country variables (output, price level, exports to the euro area, trade partners' output, interbank interest rate, key monetary policy rate [if applicable] and exchange rate visà-vis the euro [if applicable]). The model is estimated in a monthly frequency from January 2008 to December 2015 with four lags. It is assumed that SEE country variables do not influence euro area variables (so-called block exogeneity). The shocks are identified via sign and zero restrictions in order to distinguish a non-standard monetary policy shock from a conventional monetary policy shock and from endogenous balance sheet movements.

Figure 1. Key policy rate (in percent) and inverted Eurosystem balance sheet assets (in EUR trillion)

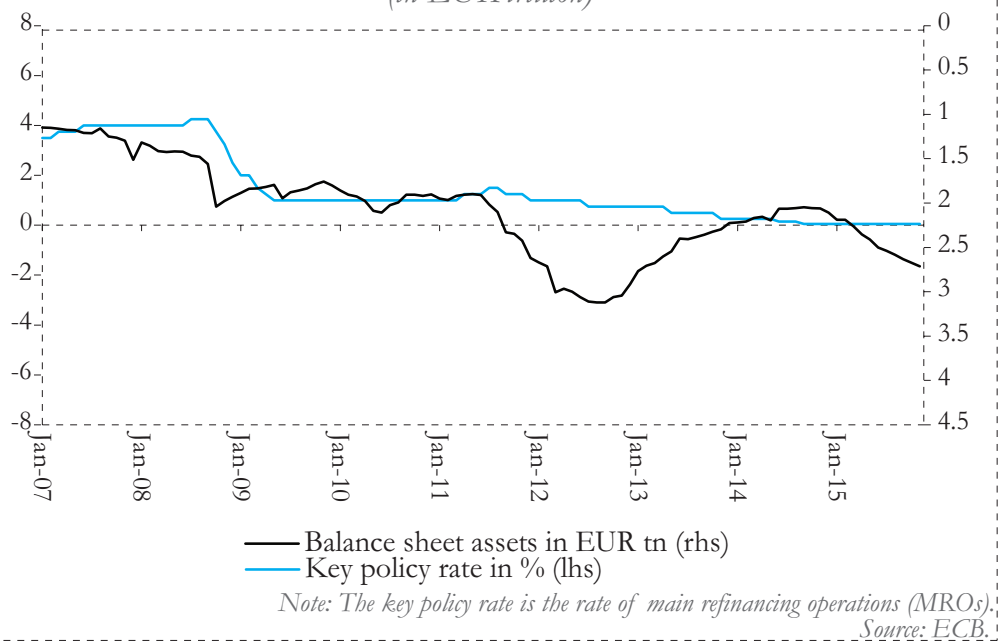




\section{RESULTS AND CROSS-COUNTRY COMPARISON}

As a response to the ECB non-standard monetary policy shock, output rises in approximately half of the countries, with the largest response being observed for Croatia, followed by Serbia and Bulgaria (Figure 2) ${ }^{4}$. The output of the Albanian, former Yugoslav Republic of Macedonian, and Romanian economies does not respond significantly to the shock. Compared to the transmission of the balance sheet shock within the euro area, the spillovers are sizeable, and in the case of Croatia and Serbia, even larger than in the euro area itself.

Figure 2. Output responses to ECB non-standard monetary policy shock

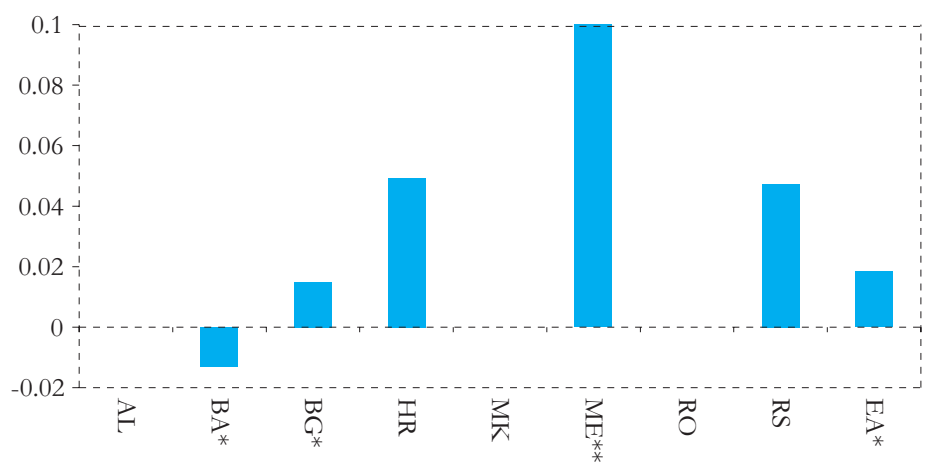

Source: Author's calculations.

Notes: Peak responses to a 1 standard deviation expansionary balance sheet shock (approx. $+0.7 \%$ ) within the first 12 months in percent. * denotes not strictly credible responses. ** For Montenegro, the response of industrial production is depicted. !

Following the euro area shock, all countries exhibit a distinct price level response (Figure 3), where the peak response is by far the strongest for Serbia, followed by the former Yugoslav Republic of Macedonia, Romania, and Bulgaria. The relatively strong price responses, which are more pronounced for around half of the countries than the euro area response itself, are in line with the high share of imports from the euro area that ranges from around one third to over 50 percent of all imports in SEE countries.

Montenegro's output also responds positively, but is measured in industrial production, thus the effect on GDP is unknown. 
Comparing the peak responses across countries, the results suggest that the exchange rate regime does not play a significant role in shaping the size and magnitude of output and price spillovers, as countries with flexible exchange rates lie on opposite ends of the range. This result is not surprising, as for the three countries operating under a (in principle) flexible exchange rate regime, none of the domestic exchange rates shows a pronounced response to the euro area balance sheet shock in the model output ${ }^{5}$. This result is in line with relatively stable exchange rates (especially for Albania and Romania) in the sample period, reflecting the general reluctance to tolerate exchange rate fluctuations also under the flexible exchange rate regimes adopted, in principle, in Southeastern Europe.

\section{Figure 3. Price level responses to ECB non-standard monetary policy shock.}

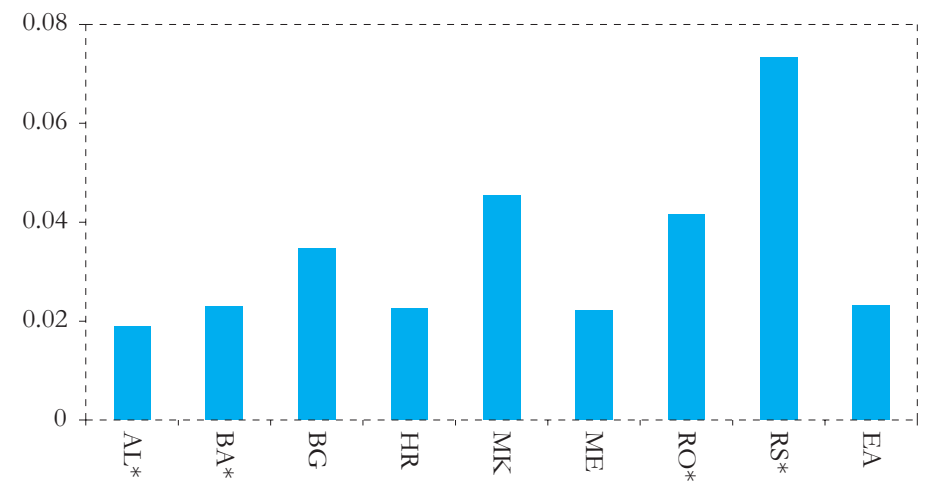

Source: Author's calculations.' Notes: Peak responses to a 1 standard deviation expansionary balance sheet shock (approx. $+0.7 \%)$ within the first 12 months in percent. * denotes not strictly credible responses.

Regarding potential transmission channels, the results suggest that the impact of a nonstandard monetary policy shock on SEE exports to the euro area is the largest for the former Yugoslav Republic of Macedonia and Montenegro, followed by Bulgaria, Serbia, and Albania (Figure 4). On the other hand, the real transmission channel does not seem to be considerable in Bulgaria, where no significant increase of exports can be observed, and in Croatia and Romania, where exports react negatively to the balance sheet shock.

The peak exchange rate responses are not shown here due to the weake and noncredible responses. Impulse response functions of the exchange rate reaction can be found in the Working Paper version. 


\section{Figure 4. Export responses to ECB non-standard monetary policy shocke}

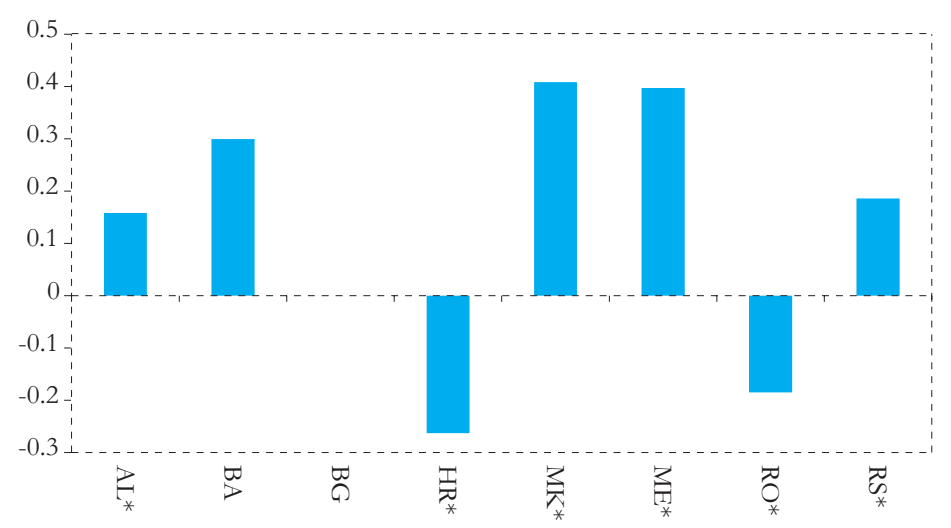

Source: Author's calculations.

Notes: Peak responses to a 1 standard deviation expansionary balance sheet shock : (approx. $+0.7 \%$ ) within the first 12 months in percent. * denotes not strictly credible responses.

Taking into account both the financial and the real transmission channels, it seems that for a majority of countries, spillovers are transmitted via exports, while the interest rate channel plays a significant role only in two countries, as suggested by the response of the short-term interbank market rate (Figure 5). This result might reflect the significant bank cross-border deleveraging many SEE countries experienced after the crisis. However, both indicators suffer from drawbacks due to data availability. Exports here denote only merchandise exports, since exports of services are not available, which might underestimate the export channel in countries with a high share of service exports, such as Croatia. In the case of financial flows, changes in the interbank market rate might not capture foreign direct or portfolio inflows, and, therefore, underestimate the role of the financial channel in transmitting shocks.

\section{CONCLUSIONS}

The results suggest that the ECB's non-standard monetary policy measures have had sizeable spillovers to the SEE countries: while output responds positively to a Eurosystem balance sheet shock in approximately half of the SEE countries, pronounced price 
Figure 5. Interbank interest rate responses to ECB non-standard monetary policy shock

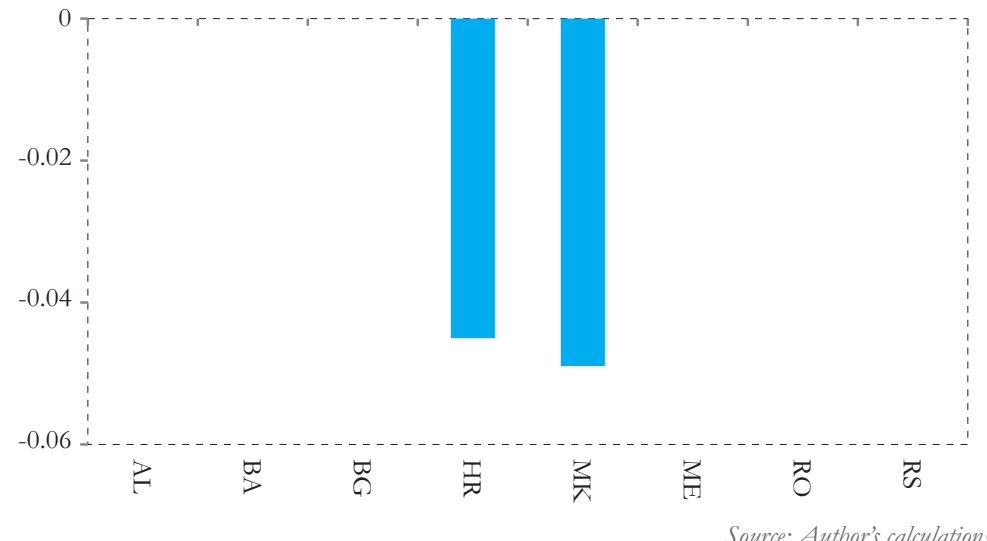

Notes: Peak responses to a 1 standard deviation expansionary balance sheet shock (approx. $+0.7 \%$ ) within the first 6 months in percentage points.

level effects can be found for all countries, potentially driven by import prices given the high euro area import share. With regard to possible transmission channels, the export channel seems to be more important than the financial channel (represented by interbank interest rates). Moreover, the results suggest that the exchange rate regime does not influence the magnitude and sign of the shock response. Whether spillovers are beneficial to the economy largely depends on the business cycle position of the respective SEE country and, more generally, on business cycle synchronization with the euro area. The current work could be extended into various directions, for example comparing nonstandard with conventional monetary spillovers, add more potential transmission channels, or compare the effects of a US monetary policy shock with a euro area monetary policy shock. 
This page intentionally left blank 


\title{
ESTIMATING THE LOWER POLICY RATE BOUND IN A EUROIZED ECONOMY ${ }^{1}$
}

\author{
Guido Della Valle \\ International Monetary Fund, Monetary Policy Advisor
}

\section{INTRODUCTION}

With this presentation, I would like to share the experience of the Bank of Albania (BoA) with the estimation of the lower policy rate bound, at a time, at the beginning of 2016, in which BoA was confronted with very low inflation rates, a challenging external environment, and a risk of disanchoring inflation expectations. The presentation is based on the framework developed and deployed by the Bank of Albania to estimate how far they could lower policy rates to counteract downside risks to price stability. The framework benefited from the IMF Technical Assistance (TA) funded by the Swiss Government. The reason we are presenting it here and have written a Working Paper is the belief of the authors that in a context of lower global real interest rates more frequently monetary authorities will be confronted with similar policy challenges and may benefit from the conceptual framework developed by the Bank of Albania.

In this presentation, I will first provide some information on the context in which the analysis underlying the Working Paper has been conducted. I will, then, present the framework used to conceptualize the problem of the lower policy rate bound. On the basis of this framework, the lower bound depends on three groups of factors: (1) those related to the effectiveness of the transmission mechanism; (2) those related to financial stability; and (3) some sundry extra factors. I will then present the framework developed by the BoA to monitor the dynamics of the variables in the above mentioned group. I will finally conclude.

1 Guido Della Valle, Erald Themeli, Romain Veyrune, Ezequiel Caberon, and Shaoyu Guo, 2018, "The effective lower bound for the policy rate in euroized economies: an application to the case of Albania," International Monetary Fund, Working Paper, forthcoming.. 


\section{THE CONTEXT}

At the beginning of 2016, the Bank of Albania, as evidenced by Figure 1, was faced with strong disinflationary forces deriving from disinflation from the euro area, declining commodity prices, and a one-off supply shock. The resolve and the timeliness with which BoA reacted, lowering the policy rate to the all-time low of 1.25 percent, anchored the inflation expectation and facilitated a gradual recovery of the inflation rate. At that time, however, when the extent and the length of disinflationary forces were unclear and the risk of dis-anchoring inflation expectations more material, key policy questions were: (1) how far policy rates can be lowered; (2) which factors should be taken into account to estimate the lower policy rate bound; (3) at which point non-standard measures could be considered relatively more effective in the pursuit of the price stability objective than conventional monetary policy; and (4) which measures would have been relatively more effective in Albania.

The paper and this presentation are based on the conceptual framework with which the Bank of Albania with IMF TA tried to address the first three questions. In our view, the same framework can be effectively used elsewhere.

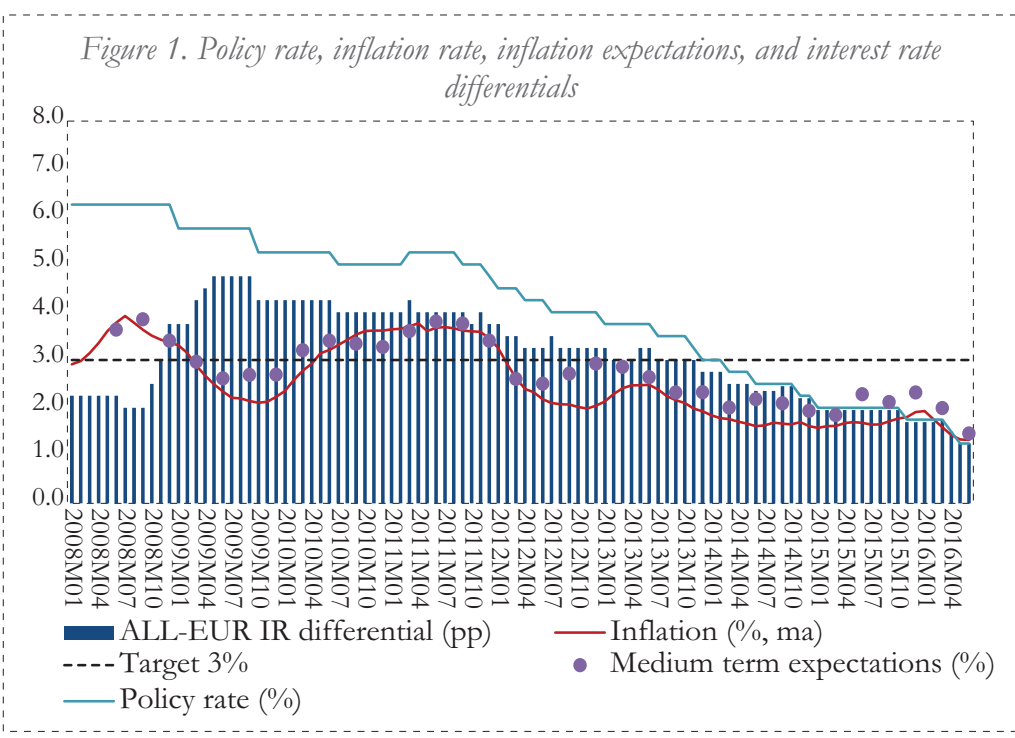




\section{KEY CONCEPTS}

For the purpose of our analysis, we have introduced and defined three concepts: the zero lower bound, the technical lower bound, and the effective lower bound. Zero has long been considered synonymous with technical lower bound. Until a few years ago, the economic doctrine considered negative interest rates de facto impossible. According to the doctrine, since bank reserves and current account holdings can be converted into currency on demand and since currency has zero nominal interest rates, negative rates would have been impossible, as banks, companies, and individuals would have reacted to any attempt to lower the interest on deposits below zero by converting account holdings into currency. This assumption has never been fully accurate.

Already a century ago, Silvio Gesell, in 1916, proposed levying a stamp tax on currency to generate a negative interest rate. Keynes discussed this scheme, approvingly, in the General Theory. More recently, a number of modern-day variants of the stamp tax on currency have been proposed. However, even without recurring to these schemes, difficult to justify from a political perspective, the recent experiences of the Swiss National Bank, the Danmarks National Bank, and the ECB have shown that policy rates can be lowered below zero. Cash entails holding and transaction costs so that banks and corporates accept moderately negative account remuneration to avoid the cash holding and handling costs.

Hence, zero is not the theoretical minimum at which rates can be lowered without triggering cash hoarding and large-scale conversion of account holding into cash engendering a complete breakdown of the transmission mechanism, which we define as the technical lower bound, but also because there are several other considerations related to the effectiveness of the transmission mechanism and to financial stability which explain why a central bank may not wish to lower rates to the theoretical minimum possible. This defines an effective lower bound as the minimum level at which the main policy rate can be cut without engendering adverse consequences that may not be neutralized via additional policy tools and that may outweigh the expected benefits of the policy rate cut. Our proposed 
conceptual framework is visualized by Figure 2 .

Figure 2. Technical and effective lower policy rate bounds

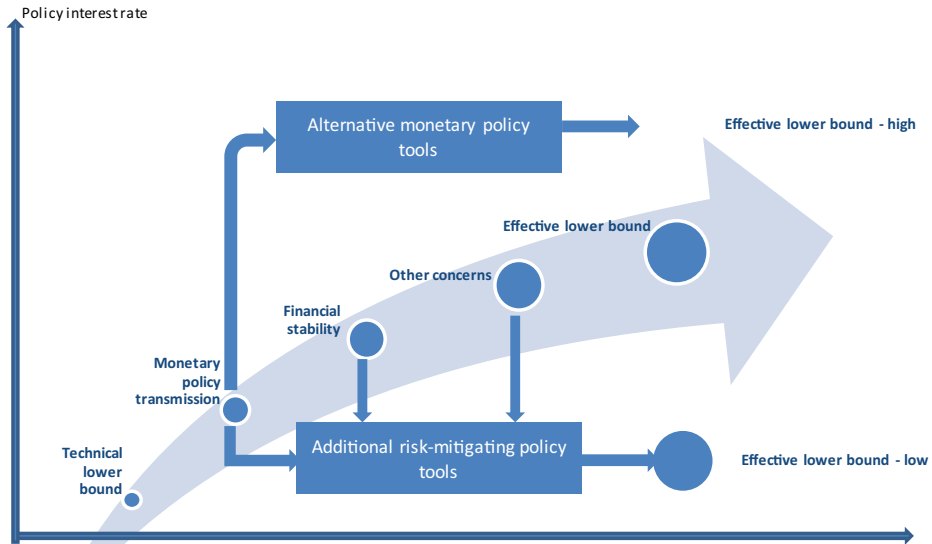

There is a technical lower bound, as the theoretical minimum at which policy rates can be lowered. It may be above or below zero based on several considerations related to the relative convenience of cash versus electronic money, the regulatory premium attached to retail deposits, and the perceived soundness of the banking system. However, in light of considerations related to the effectiveness of the transmission mechanism, and to financial stability considerations, a central bank may refrain from lowering the rates to that technical minimum and consider a different and higher level as the minimum at which rates can be effectively lowered. If the availability of alternative, nonconventional monetary policy tools is taken into consideration, which at a certain point can be considered relatively more effective, the effective lower bound can be set at a higher level. On the other hand, the availability of risk-mitigating policy tools to address some of the negative consequences of low policy rates (for example tiered remuneration of excess reserves) may push the effective lower bound lower. We will now look more closely at the factors from which the effective lower bound depends. 


\section{IMPAIRMENT IN THE TRANSMISSION MECHANISM}

The first group of factors concerns the possible impairment in the transmission mechanism at low policy rates.

The impairment in the transmission mechanism is one of the main reasons central banks may refrain from lowering policy rates further. The lower effectiveness of the traditional monetary policy channel can derive from rigidities and non-linearities, but may also take in euroized economies a peculiar form, which is a function of the exchange rate. At already low levels, lower policy rates may not be transmitted to lending rates. Lower policy rates are in general transmitted to the real economy primarily via lower lending rates that should ultimately stimulate credit demand, credit growth, consumption, investment, and aggregate demand. They are also transmitted via lower deposit rates that, ceteris paribus, should encourage higher present consumption and lower savings. However, if financial intermediation is impaired, banks may not be able to lower deposit rates to prevent deposit outflows. Furthermore, if funding costs are rigid at the zero bound, banks may not react to lower policy rates with lower lending rates as they attempt to maintain their lending margin unchanged with a view to preserving profitability.

In case a negative deposit rate, banks may try to compensate for the increase in the cost of retail deposits by increasing their lending rates. This effect reportedly took place in a few countries in which policy rates were lowered below zero. It may, however, also take place when retail deposit rates are approaching the zero bound. In these cases, further monetary policy easing may either result in compression in interest rate margin or is hardly transmitted to lower lending rates. This is well documented.

However, in partially euroized economies, like Albania, the impairment in the transmission mechanism can take a peculiar form, as evidenced in Figure 3, providing a stylized description of the bank lending and exchange rate channels of monetary transmission. 
Figure 3. The transmission mechanism in euroized economies

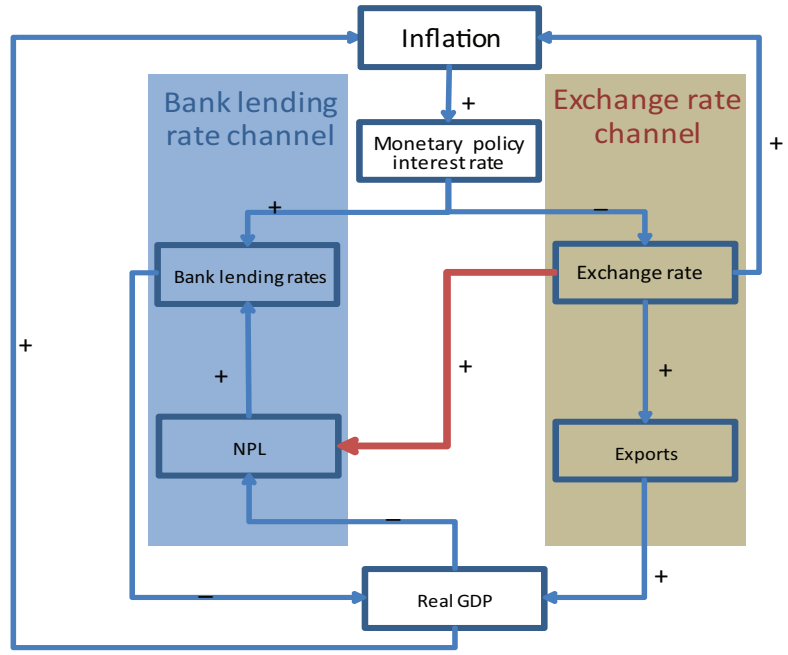

The bank lending rate channel is activated through the impact of a monetary policy decision on the cost of funding for the banking system. Changes in the cost of funding are then transmitted to bank lending rates, which, in turn, will affect the spending decisions of households and businesses, and finally affect domestic demand, the labor market, and inflation. Bank lending rates are also driven by a variety of risk premia, among which one of the most prominent is that related to the probability that the borrowers default totally or partially on their obligations. Such default probability is usually influenced by cyclical conditions and tends to grow during recessions and decrease during expansions; increases in the probability of default tends to translate to the fraction of nonperforming loans (NPL) in total lending, which can be used as a proxy for the probability of defaulting.

The exchange rate channel is activated through the change that a policy decision implies in the relative returns of domestic and foreign denominated assets. This implies movements in the exchange rate. The exchange rate channel usually impacts on inflation both directly and indirectly. The directimpact stems from the effect of the exchange rate movement on the price of imported goods; the indirect impact is associated to gains/losses in foreign competitiveness, which affect real exports and real GDP. 
In ideal conditions, the transmission of monetary policy decisions through these channels has a predictable and consistent impact.

In a euroized economy, the two channels of transmission would tend to interact negatively. An exchange rate movement would affect the value of loans denominated in euro and have an impact on the ability of the borrowers to repay their euro-denominated debts, which would, in turn, imply a change in their probability of default, and in the fraction of NPLs.

With the transmission mechanism depicted in Figure 3, the impact of a monetary policy decision becomes difficult to predict even in qualitative terms. The exchange rate channel, while still involving its direct and indirect effects on real GDP and inflation, would now have an additional effect on NPLs, and hence on bank lending rates, which would tend to counterbalance the normal impact of the monetary policy decision. In an extreme case, and assuming that the exchange rate depreciates following a monetary policy easing, NPLs could be so adversely affected that the resulting transmission to bank lending rates could totally impair the functioning of the bank lending rate channel via higher rates and lower credit provision, and possibly offset the positive effects of the depreciation on inflation, stemming from higher competitiveness and higher import prices.

The transmission of monetary policy is further complicated by difficult-to-predict non-linearities. A reduction in policy rates may engender an exchange rate depreciation only when the interest rate differential drops below a certain threshold; likewise, only large exchange rate depreciations may have a sizeable effect on NPLs; a spike in NPLs may impair the banking lending channel only when they exceed certain levels eroding the banks' capital ratios.

\section{FINANCIAL STABILITY}

Regardless of any financial stability mandate of the central bank and although the extent in which monetary policy should take into account financial stability considerations in its reaction function is 
an issue not entirely settled yet, it is broadly agreed that (1) financial stability risks - when they materialize - engender a significant and long-lasting output loss; (2) financial stability risks can be heightened when monetary policy enters the relatively uncharted waters of low policy rates; and (3) monetary policy is a relatively blunt tool to deal with financial stability risks. There are extra tools that may in principle better address and mitigate these risks. In this context, we have identified five risks engendered by low policy rates in the Albanian context. I will focus in my presentation on just a few of them.

\subsection{Policy rates, exchange rate, and NPLs}

We have discussed already the effect that any exchange rate depreciation may have on NPLs. This is confirmed by the Albanian experience with the exchange rate depreciation in 2009, as evidenced in Figure 4.

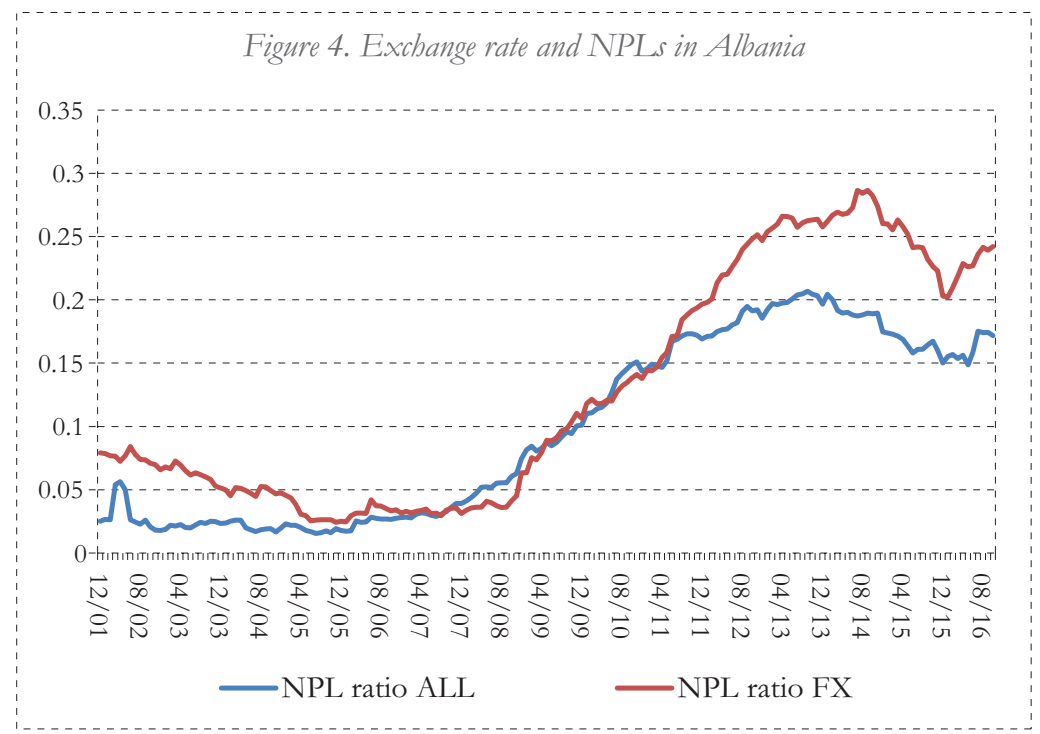

Allowing for the lags and non-linearities present, this depreciation was one of the major drivers in the subsequent increase in the risk premia, as evidenced by the clearly higher incidence of default in the 
portfolio of FX loans vis-à-vis the portfolio of lek loans. Stress test analysis at the Bank of Albania indicates that a 10 percent depreciation adds 3.1 percentage points to NPLs for foreign currency loans in the first year of the exercise and 2.1 percentage points in the second year. Higher NPLs do not matter only for the potential impairment of the transmission mechanism, but also from a financial stability perspective.

\subsection{Euroization}

Low lek interest could also encourage more euroization, everything else being equal. Demand of euro deposits is in part driven by optimal portfolio choice of risk-averse investors interested in the risk-adjusted return of their portfolios and in euro deposits as hedge against adverse foreign exchange shocks. Lower domestic interest rates by reducing ceteris paribus the relative attractiveness of domestic deposits vis-à-vis foreign exchange deposits, increase euroization, and accentuate in the long-term the financial vulnerabilities arising from higher levels of euroization. Hysteresis effects from past periods of instability mean that foreign currency deposits are considered a better safeguard against adverse economic shocks. Domestic deposits should therefore provide a yield premium to make depositors indifferent between the two.

Analysis of past data shows a significant correlation between interest rate differentials and the share of lek deposits. Except during brief crisis-related episodes, the interest rate differential remains an important explanatory variable of the currency composition of new deposit flows. This is evidenced by Figure 5, showing a strong correlation between interest rate differential and the currency composition of new deposits. 
Figure 5. Interest rate differential and currency composition of new deposit flows
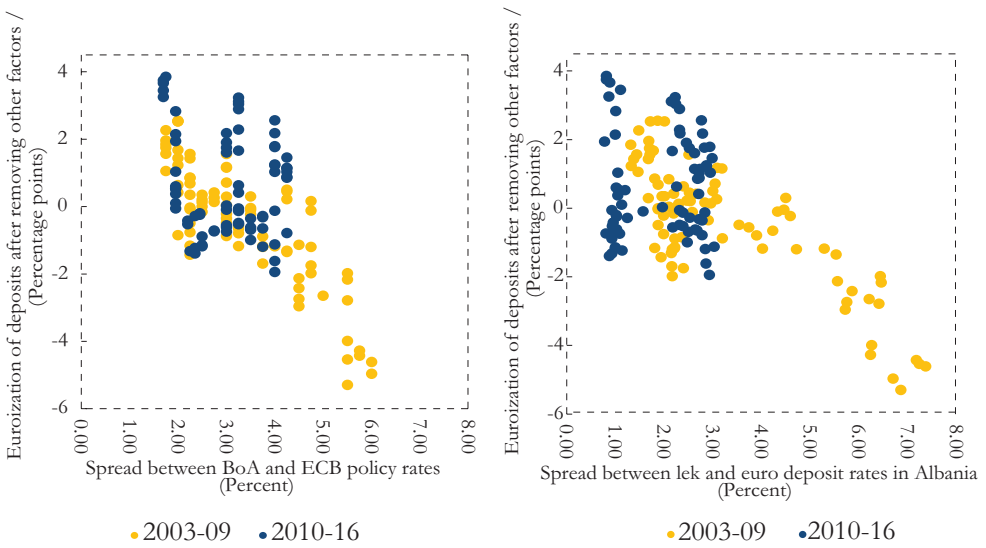

Rigidities, non-linearities at the zero lower bound accentuate the problem due to negative ECB policy rates. If foreign currency deposit rates cannot fall below zero, the BoA may consider it undesirable to lower policy rates beyond the point at which the bank rates and the domestic assets nominal yields fall to a level no longer attractive compared with the yields on foreign currency deposits, which will unlikely fall below zero regardless of the foreign policy rates. If leaning against and reducing euroization is a policy objective, the preservation of the interest rate differential necessary to prevent any large-scale shift becomes a more compelling policy constraint.

\subsection{Funding composition}

A deteriorating funding structure would also be expected to impact the bank risk-taking behavior. Another side effect of the low interest environment is a "thinning of the middle" in the maturity structure of the banks' funding structure. As interest rates in "traditional" savings instruments (bank deposits with a maturity between one and 12 months) go down, savers have moved either into current accounts and demand deposits, in search of liquidity, or into longer tenured deposits, in search of yields. This shift is depicted in Panel 
A of Figure 6. This movement has not induced though: (1) a shift into more marketable or liquid instruments on the asset side of the banking system, such as government papers (Figure Panel B); (2) a shift into shorter-term government papers (Figure Panel C), or (3) a shift into credit of lower duration (Figure Panel D).

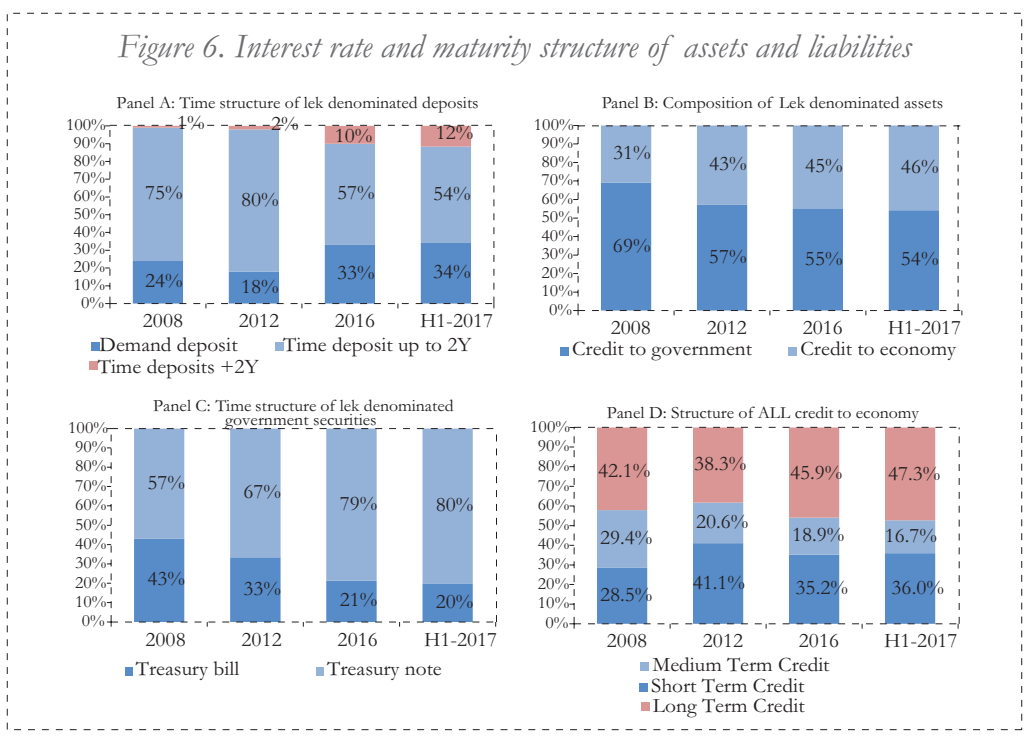

\subsection{Other factors}

In addition to financial stability and the effectiveness of the transmission mechanism, central banks may want to consider additional factors in their estimation of the effective lower bound. Such considerations would derive from other objectives the central banks are legally mandated to pursue. Alternatively, these considerations might be derived from risk factors that would indirectly and over long-term horizons affect economic or financial stability, or might impede on the ability of the central banks to pursue their primary objectives. We identify, here, two possible risk factors, such as the effect on savings, which in developing economies, starting from a lower capital stock, can be important to preserve the incentive for gradual fixed-capital formation, and any effect on credit allocation. 


\section{THE MONETARY POLICY BAROMETER}

In order to monitor in a comprehensive manner the effect of the factors affecting the estimation of the effective lower policy rate bound, the BoA developed the "barometer," a monitoring tool, in 2016. The tool shown in Figure 7 represents a way to operationalize the monitoring of the dimensions described and how they affect the effective lower policy rate bound.

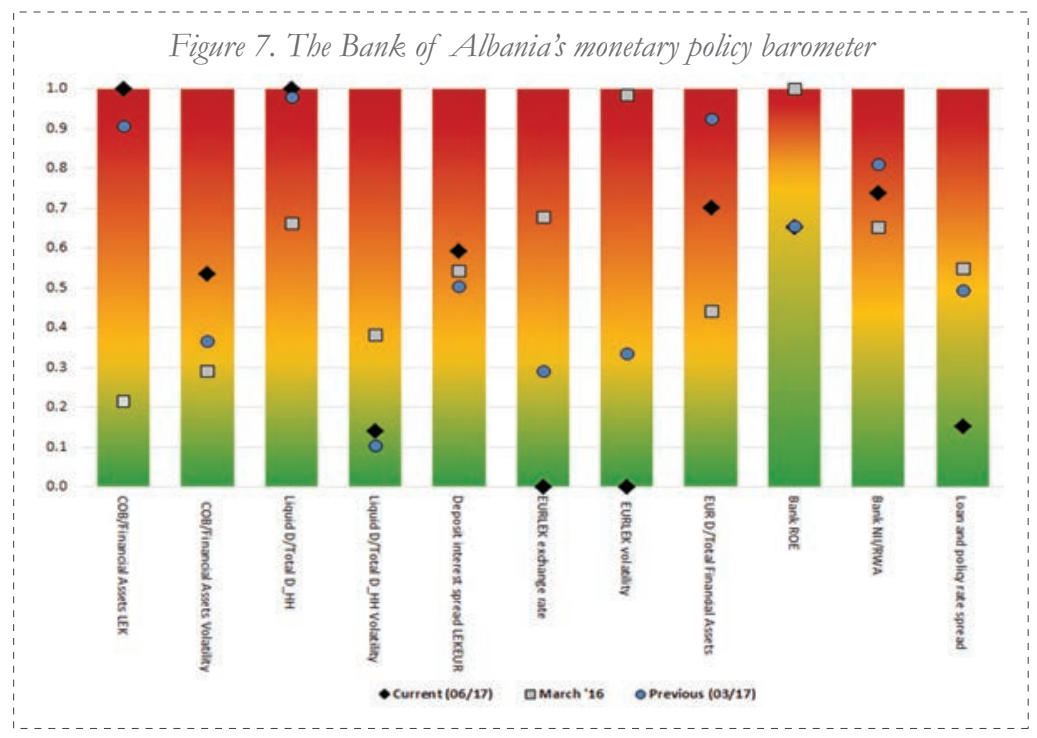

The barometer is used as a signaling tool for when the transmission of lowering interest rates is weakening and/or is producing undesired effects with regard to financial stability concerns. Several indicators are observed. Their performance is compared against a benchmark measured as their respective average level and/or standard deviation over the past two years. Deviations of the current value from the mean are observed to obtain warning signals. The values of each indicator are normalized in a scale of 0 to 1 , where these numbers correspond to the lowest and highest values of the indicator over the past two years. The mean of the series indicates the midpoint of this interval. Hence, current values approaching the upper limit (1) signal worsening of the performance of that indicator. The opposite holds if current values are approaching the lower limit of (0). In order 
to have a simple visual interpretation, values falling in the red area represent a signal for warning, while those falling in the green area represent safe conditions. The barometer represents an effective tool to monitor the different relevant indicators comprehensively. It signals the extent to which undesirable effects are materializing and the relative strength of these effects. It facilitates and guides policy judgment, but it does not replace it. The indicators to use in the barometer, their relative importance, their number, and the scale to use for each indicator can obviously be adjusted.

\section{CONCLUSIONS}

The technical lower bound can be quantitatively estimated on the basis of the currency carry costs relative to the account holding costs. The effective lower bound does not coincide with the technical lower bound. There are several reasons central banks may not wish to lower rates to the theoretical minimum.

The effective lower bound depends not only on the structural features of the economy and of the financial system but also on how central banks interpret the trade-off between the effects of different available options and the relative merits of different policy tools.

The effective lower bound may change over time, not only because economic agents adapt, but also because policy options vary and the case for low policy rates may become more compelling after alternative non-conventional tools have been used.

The effective lower bound varies from country to country, and it requires policy judgment aided by a well-established monitoring framework. In the case of Albania, from a theoretical perspective, the single, most significant risk to which the Albanian economy and the financial system are exposed is a significant, abrupt depreciation of the exchange rate, impairing the debt servicing capability and the creditworthiness of unhedged borrowers. Such depreciation may result from a lower interest rate differential between foreign currency and domestic assets altering their relative attractiveness. Since the BoA entered the easing cycle, not only has such depreciation not 
taken place, but the exchange rate has appreciated. This would indicate that there is room for further policy easing as needed.

Despite the exchange rate stability, the BoA monitoring system provided initial evidences of disintermediation, weakening in the funding profile of banks with a shift toward shorter-dated funding, higher demand of large-denomination lek banknotes as store of value, and lower, though still healthy, banks' profitability. At the same time, the decreased interest differential increased the risk of fueling large-scale portfolio shifts and subsequent large-scale depreciation, while the relatively persisting higher euroization levels increased awareness of the need to lean against euroization. At the time in which the persistent downside risks to baseline scenario of the gradual recovery in inflation rate could not exclude the need of further accommodative measures, the analysis facilitated by the BoA's barometer led to the conclusion that the continuous effectiveness of the transmission mechanism and the overall stability of the exchange rate provided room for additional policy rate cuts, in case they had been needed. However, the indicators of stress and the lack of some of the traditional transmission channels of very low policy rates - such as higher risk -taking toward alternative investment instruments - indicated that such room was overall limited, that the room should have been used with caution, and that the possible use of non-conventional policy tools could have become a more compelling option once the limited room had been used. 


\section{IMPLICATIONS FROM THE LOOSE ECB}

MONETARY POLICY FOR THE REGION

(FOCUS ON MACEDONIA)

Anita Angelouska Berhoska

National Bank of the Republic of Macedonia, Vice Governor

First, let me thank the Bank of Albania and the IMF, the organizers of this event, for the invitation to be here as part of this excellent event, and share with you the thoughts of the Central Bank of Macedonia on the implications for the Western Balkan region of the recent very accommodative ECB monetary policy. In particular, I will focus on Macedonia.

As it has been already extensively discussed, the ECB has recently provided an unprecedented monetary stimulus via a package of different standard and nonstandard policy measures. This monetary stimulus is contributing to the improvement of the real economies in the eurozone and has helped overcoming impairments in the functioning of financial markets. Given the strong trade and financial links of our region in general, including the Republic of Macedonia, with the European Union (EU), spillover effects of ECB policies are one of the key policy questions that we, as policymakers, are confronted with and need to assess and anticipate.

Some figures may help quantify the regional trade and financial links to the euro area. Trade exposure of the region with the euro area represents 62 percent of GDP, with the highest exposure recorded in Bosnia and Macedonia. Also, the financial channel is a source of important linkages. The main source of FDIs and private transfers is the EU. Banks headquartered in the EU hold a predominant market share in most of the countries in the region.

As a small and open economy, Macedonia has high and rising trade links with the EU. Some figures may corroborate this statement. For example, 80 percent of the stock of the FDIs comes from the EU, about 80 
percent of our exports goes to the EU, about 60 percent of our banking system is owned by European banking groups, and about half of the private transfers, which are a very important overall financing source of the economy, comes from the EU. Therefore, in this context, it is not a surprise that the assessment of the spillover effects of ECB policies is a very topical issue for us and for all countries in the region. This is not only from the point of view of the benefits that our economy has enjoyed, or of the extent it can enjoy the benefits of very accommodative ECB policy, but also from the perspective of risks that we might face when the course of the ECB monetary policy changes.

In light of the multiplicity of the linkages with the EU, the spillover effects can take place through a number of different channels. They include the capital inflows channel, that is, the re-allocation of part of the liquidity injected by the ECB on the financial markets in the region. Such a re-allocation mechanism may engender and fuel crossborder capital flows, leading to a compression of the yields and lower risk premia on different kinds of asset classes. Furthermore, lower ECB interest rates provide room for downward adjustments of the main policy rate of all the countries in the region, which are, subsequently, transmitted to lending rates in the region as a whole, and in particular, in the countries with some form of fixed exchange rate arrangement. Lower ECB policy rates, therefore, allow room for downward policy adjustment without encouraging capital outflows or further euroization, which is an issue in all the countries in the region.

Positive spillover effects also take place via the trade channel. Recovery of the foreign demand provides positive impulse for the export sector. The improved economic prospect for the EU, as our main trading partner, positively affects not just the export segment of the economy, but it has wide-ranging effects throughout the whole economy, through the investment channel, or through the labor market to consumption. Therefore, a pickup in foreign demand underpins a faster recovery of the real economy of the Western Balkans. Furthermore, consumer confidence and business sentiment are other transmission channels. Prospects for stronger recovery of the main trading partners can also positively affect the expectations of the domestic agents. And last, but not least, one should not forget the exchange rate channel. 
After having discussed the possible spillover effects of loose ECB monetary policy in theory, let's have a look at their effects in practice. In my presentation, I will first analyze whether the loose ECB policy has led to capital inflows in the region, what their dynamics are, and what their structure is. First of all, I have broken down the afterfinancial-crisis period in two sub-periods to see whether the ECB large-scale asset purchase programs (LSAP) in the past couple of years have resulted in larger capital inflows in the countries in the region. To this end, I use the Balance of Payments (BOP) data as a rough indication of the capital inflows. They are on an accrual basis and their recent dynamics may reflect several contributing factors, but at least they provide an aggregated picture of what has been taking place in the region as a result of the loose ECB policy.

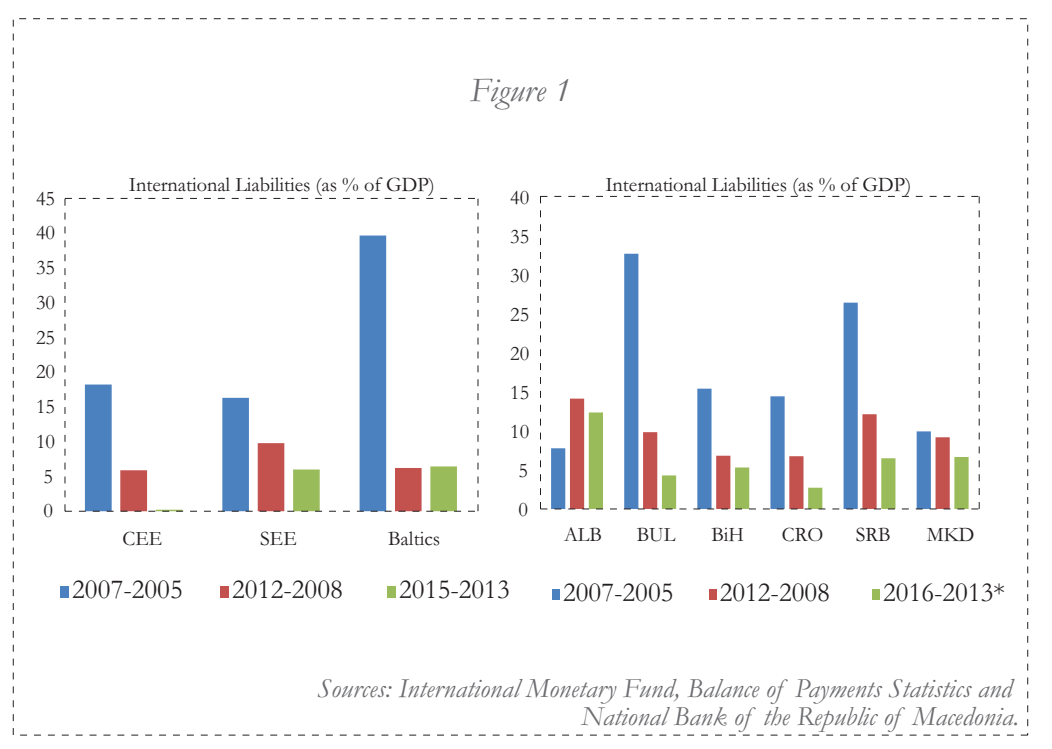

We can see from Figure 1 that capital inflows in the region have continued, although at a somewhat slower pace, across all countries in the region. For example, if in the pre-crisis period they accounted for about 16 percent of GDP, in the post-crisis period they have decelerated to about 6 percent of GDP. This deceleration is evident across almost all the countries in the region, although it appears to be larger in the case of Bulgaria and Serbia. In the case of Bulgaria, there is a downward adjustment close to 30 percentage points, and 
in Serbia close to 20 percentage points. On the other hand, the adjustment in Macedonia is smaller. Capital inflows decline just a couple of percentage points of GDP. It is interesting to note, however, that the deceleration of the capital inflows continues in the second sub-period when, pursuant to the launch by the ECB of the large-scale Asset Purchases (LSAP), one would expect to see larger cross-border flows.

The figure also shows that Albania seems to be an outlier, since, unlike in other countries, there is a pickup in the capital inflows in both sub-periods. The colleagues from Albania can better explain the reasons underlying this observed trend. Despite the lower pace of capital inflows, the deceleration that we are seeing in the region is lower compared to the Central European countries and the Baltics. In the Central European countries, capital inflows have overall stalled, and in the Baltic States there is a significant downward adjustment, partially reflecting the pre-crisis period dynamic of particularly large inflows.

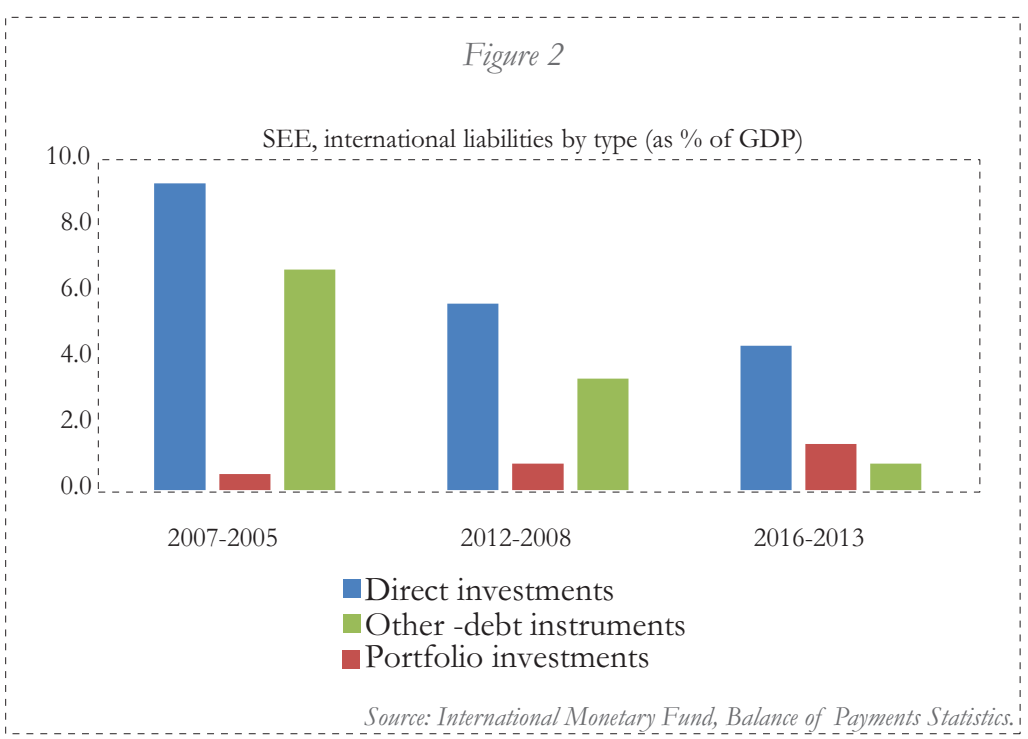

If we now turn to the structure of the capital inflows, we can see that the deceleration on average for the region is taking place across almost all types of capital inflows. For example, if you look at Figure 
2, the blue bar represents the FDIs. The FDIs decelerated roughly from 9 percent of GDP to about 5 percent of GDP. The largest drop is taking place for other financial flows. This category, other financial flows, is a residual category representing everything that is not portfolio or FDI investment. It reflects different kinds of financial or commercial loans. Other financial flows declined from about 7 percent of GDP to about 1 percent. More structurally, if you look at the sectorial composition of this category in the BOP data, you can clearly conclude that the decline can be explained to a large extent by the process of deleveraging of the banking system. One could therefore preliminarily conclude that accommodative ECB monetary policy and the LSAP have not benefited the bank lending channel in the region. The liquidity injected via the ECB measures in the European banking sector has not been redeployed in the region. On the contrary, in most countries, we are witnessing a continuous process of banks deleveraging, which can be explained by the new, tighter regulatory framework banks are confronted with. The implementation of the new Basel III standards in the medium term will obviously increase the resilience of the banking system, but, in the short term, it has some negative effects for the countries in the region.

Looking at portfolio flows, it seems that on average they have remained broadly stable, at around 1 percent of GDP. However, the average hides heterogeneity across countries. Looking at more granular data in terms of the sectorial composition, it appears that a downward adjustment of portfolio inflows in the private sector has been compensated by a pickup of portfolio inflows in the government sector.

Despite the lack of the counterfactual of what would have taken place without ECB accommodative monetary policy, overall BOP data supports the notion that ECB policy underpinned capital inflows in the region. Despite the banking system's deleveraging process, capital inflows continued in the region, albeit at a somewhat slower pace, and no reversal took place. In particular, capital inflows were underpinned by still solid FDIs, as well as portfolio inflows toward the government sector, which was one of the main beneficies, via both a quantity and price effect. 
The conclusions apply equally well to the case of Macedonia, which I will now discuss in greater detail. Capital inflows in Macedonia decelerated, although the pace of the deceleration was lower compared to the average deceleration for the region. One of the reasons are FDIs. As we look at the composition of the FDIs, as evidenced in Figure 3, I would like to underline the positive structural shift. If, in the pre-crisis period, we had about one third of FDIs channeled toward the tradable sector, in the post-crisis period we have roughly half of the FDIs being channeled in this sector. This contributes diversifying the structure of the export sector, as well as the structure of the whole economy, making it more resilient to any future potential shocks. Such developments help in addressing the structural problem of our economy, represented by a high structural trade deficit.

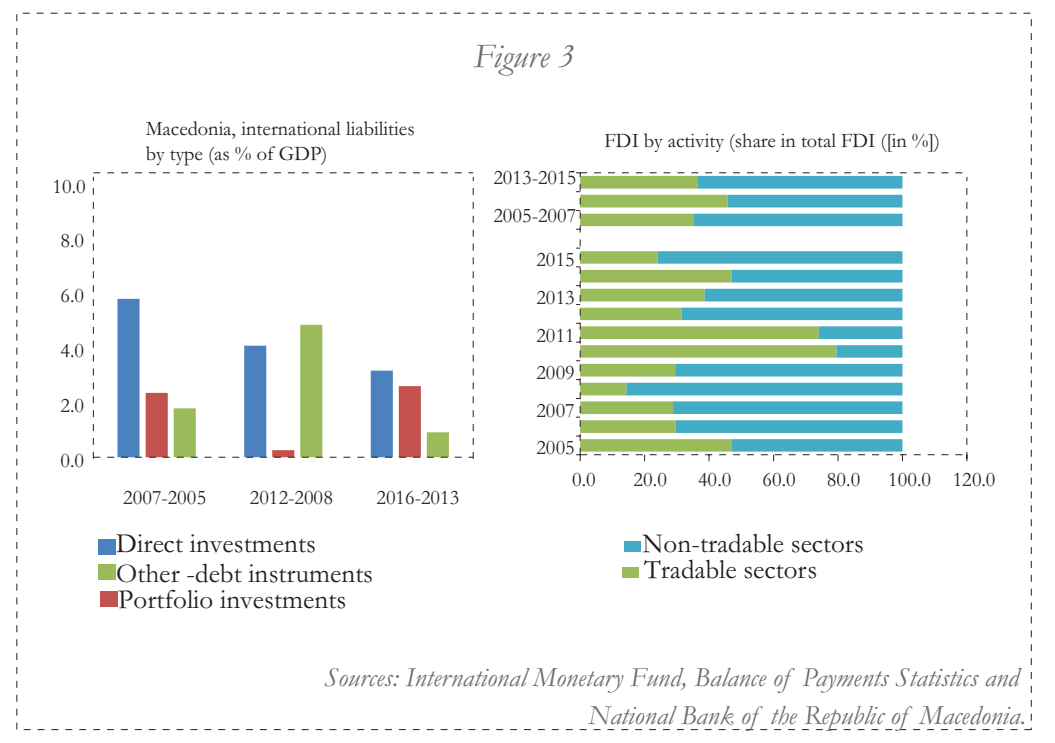

Concerning the portfolio flows, there is some volatility in the postcrisis sub-periods, mostly explained by the government borrowing. This is visible in Figure 4. Immediately after the crisis, portfolio inflows accelerated, driven by countercyclical fiscal policy. The government increased investment expenditure in large infrastructure projects to offset the negative effect of the crisis on domestic growth. This required financing for which the government stepped 


\section{Figure 4}
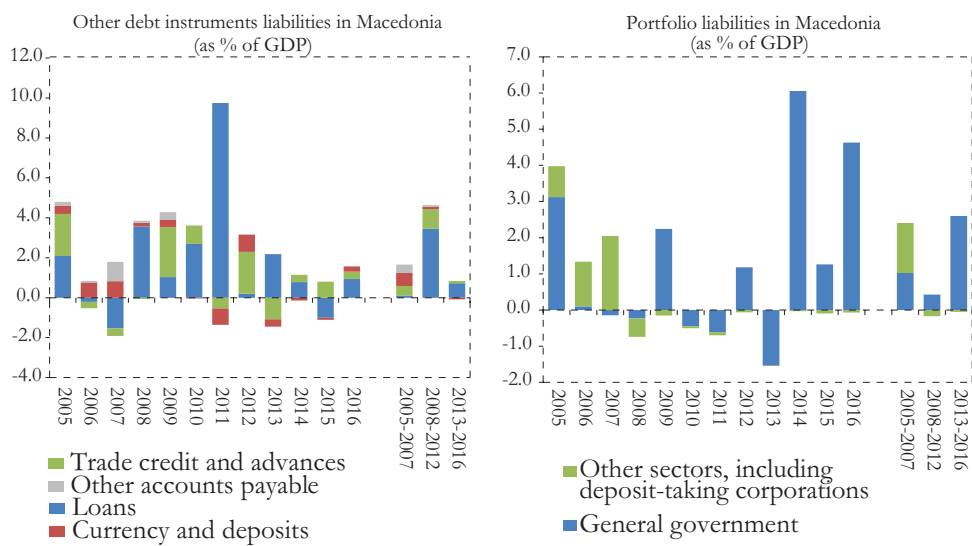

Source: National Bank of the Republic of Macedonia.

up foreign currency borrowing. The government, in our case, had space for more accommodative fiscal policies thanks to very prudent fiscal policies followed for years also in support of the de facto fixed exchange rate.

As regards to other debt flows, their dynamic is also volatile. In the first period, they picked up, then they slowed down. This dynamic is, however, also explained by the government policies. In fact, other debt flows are driven by government borrowing either directly or indirectly through a development bank that has kept borrowing to offset the effects of the banking system's deleveraging process. Overall, ECB policies seem supportive of the capital inflows in Macedonia, mostly through the channels of FDIs and through sovereign borrowing. As regards the FDI channel, the change in their composition toward the tradable sector can be explained, instead by government policies, which were aimed at attracting foreign direct investments in the free economic zones.

So far, we have seen the pattern of the capital inflows in the region. Let's look now at the implications of these capital inflows on the financial conditions in the region. ECB non-conventional measures, including the asset purchase programs and the negative interest 


\section{Figure 5}
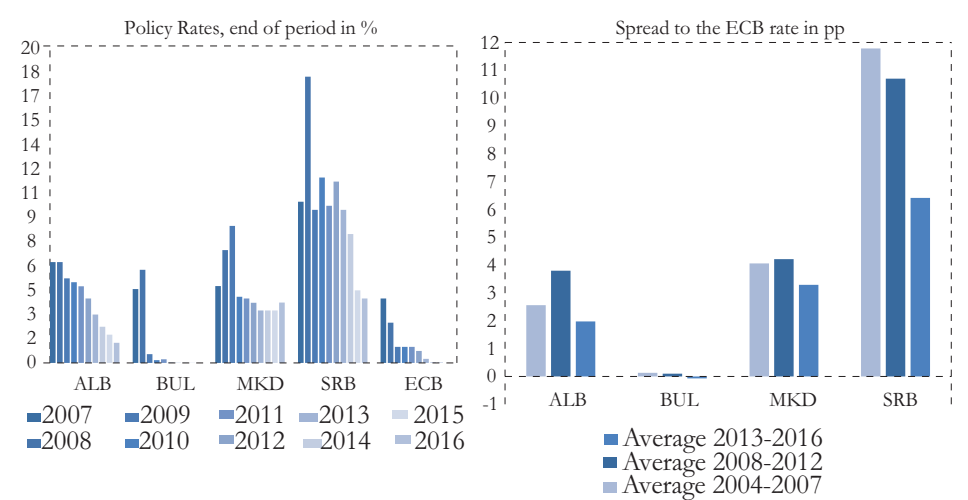

Source: Central banks' internet pages.

rates, provide room for prolonged accommodative monetary policy across all countries of the region. Regardless of the heterogeneity in the exchange rate and monetary regimes, all countries have loosened monetary policy since the beginning of the crisis. This is evidenced by Figure 5 .

In the figure, I have used the policy rate as a proxy of the monetary policy stance, but obviously, besides the policy rate, many countries have used different non-standard measures. Loose ECB policy allowed a decrease of policy rates in the region without having any destabilizing economic or financial consequences. As evidenced by the figure, the highest downward adjustment took place in Serbia and the lowest downward adjustment in Macedonia. In Macedonia, although the policy rate has been lowered less than in other neighboring countries, it is still at its all-time lowest level.

So, there are a lot of questions and ongoing discussions on the scope for additional monetary accommodation and the level of our effective lower policy rate bound. Can we move further down without having destabilizing consequences on the economy and the financial system? One of the problems that we have witnessed in the recent period is the dynamic of banks' deposits. Although the stock is still solid, in our assessment, their recent dynamic is not fully in 
line with the movement of the fundamentals, indicating that there is some reallocation of the deposits in other segments of our economy. We were looking at financial markets in general, capital markets and money market funds in particular, to see whether there is some rechanneling in these segments, but even the reallocation that we see cannot fully explain the observed deceleration of deposit growth. Deposit growth is a very important source to support credit to the private sector, for us and for all countries in the region, because bank lending predominantly relies on deposits.

A looser monetary stance has also been conducive to downward adjustment of the bank lending rates, as it is visible across all countries in region. The highest decline in the lending rates can be observed in the case of Albania, and the lowest in the case of Croatia. Macedonia is somewhere in between. The reduced cost of financing supported the credit demand, although credit growth in most of the countries still remains anemic. There are some countries in the region where credit to the private sector has continued contracting even in the most recent period. In Macedonia the lending rates reached historically low levels, leading to solid credit growth, which is in fact the highest in the region. A couple of factors might explain credit growth resilience in Macedonia. First, we avoided a credit bubble fueled by foreign inflows in the pre-crisis period, which limited the post-crisis need to deleverage. Second, only a stable banking system with good asset performances can support higher credit growth.

However, despite the low interest rate environment, public debt in the region rose significantly. This brings us to an assessment of the negative implications of ECB monetary policy. Low interest rates have not been conducive to government fiscal consolidation efforts. In most countries in the region, public debt has been on a rising trend. This is equally true in the case of Macedonia. Public debt almost doubled compared to the pre-crisis period, although it is still one of the lowest in the region. What worries us are the dynamics of the debt increase and the structure of the public expenditures. Increasing expenditures are made up only in a small extent by discretionary spending. This will create significant pressures for the consolidation of the public finances, especially when the interest rates start increasing. 
Turning the attention to the overall economic developments, just looking at the data, it seems that improved financial conditions, the recovery of the external demand, and structural factors or structural changes in certain economies have been conducive to the recovery of the economies. All countries have exceeded the pre-crisis level of GDP, with the highest increases recorded in Albania and Macedonia. In Macedonia, I would like to underline that, due to the positive structural shifts in the FDIs, there has been, to some extent, a change in the growth model, which currently relies more on the export sector.

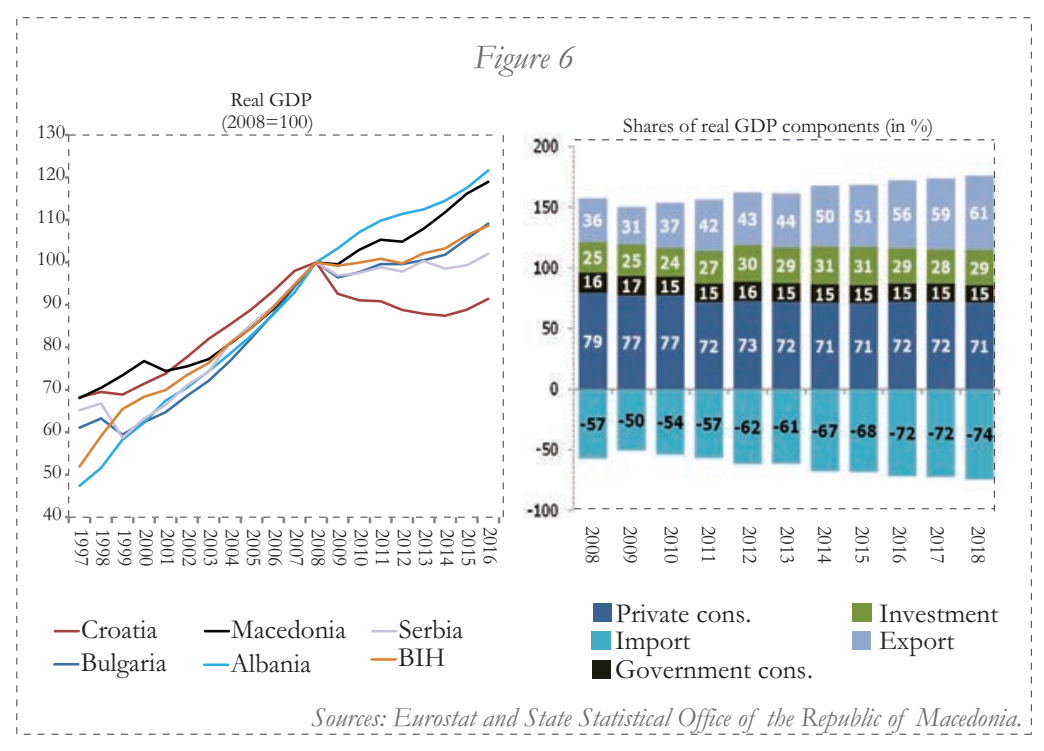

In terms of GDP composition, if we look at the chart on the righthand side of Figure 6, we can see that there are positive shifts. They include rising shares of export and import as well because export is still significantly dependent on import, but, on a net basis, this is a positive change, while the share of consumption and public and private consumption has been declining.

Given these effects from a looser ECB policy, we should ask ourselves what are the risks arising from a future ECB exit from very accommodative monetary policy. As already mentioned, there are many factors in play. The risks depend on the fundamentals of 
the economies, their vulnerabilities, the policy buffers, and the size and composition of the capital inflows.

Regarding the size and composition of capital inflows in the Western Balkans, it appears that future tightening of the ECB policies is unlikely to create significant imbalances in our economies. We don't see much pressure on the current account deficits, and we do not see real estate or stock index bubbles fueled by short-term speculative capital inflows. But, we need to remain very vigilant. If we look at the financial external exposure of all countries of the region, it remains elevated. In fact, the most recent regional outlook of the IMF points exactly to the high external liabilities of all countries in the region as their highest vulnerability, in case of future ECB monetary policy tightening. Figure 7 shows the net international investment position as a rough indication of the extent of this vulnerability. We can see that the process of rapid rise of the negative net international investment position was halted in the post-crisis period, but, still looking at the stock, it points to significant exposure and requires close vigilance from us as policymakers.

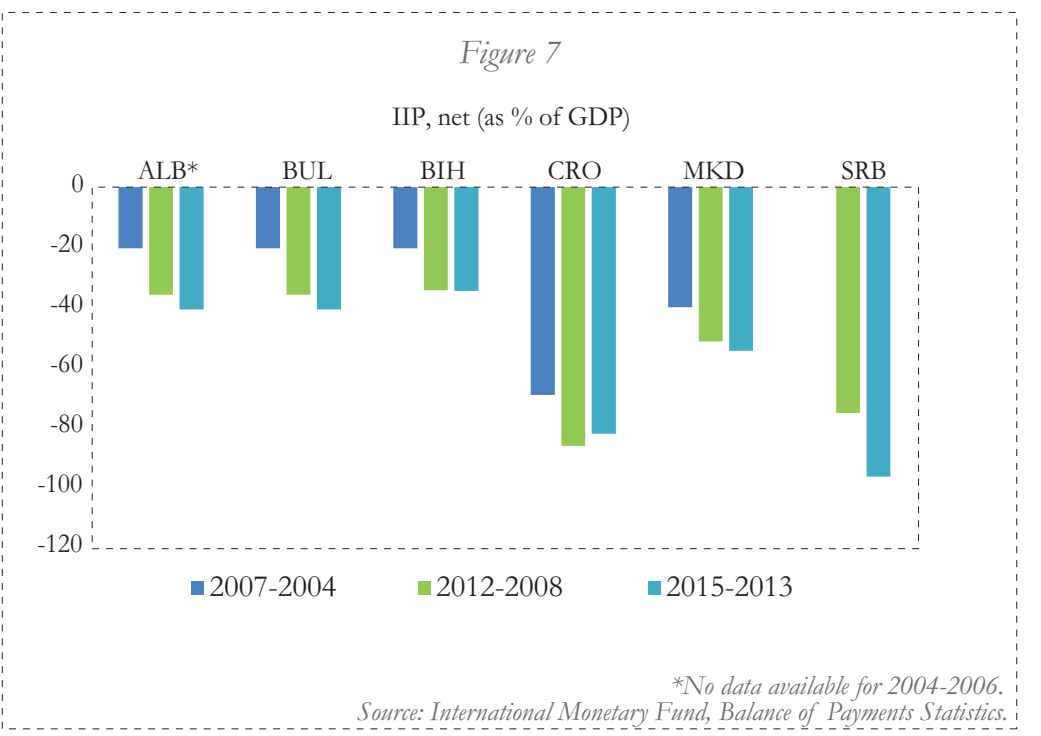

To conclude, I think that recent episodes of Fed tapering and US post-election market sell-off may provide some indications on the effects that may be expected by the future ECB exit. Based on 
the IMF data, US developments had spillover effects in Europe, including some countries in the region. There were capital outflows, although not sizeable, with negative impact on the financing spread of the economies, exchange rate, and some asset classes. There is heterogeneity in the monetary and exchange rate arrangements, as well as in economic and financing structure and fundamentals across the region, but definitely the recent experience calls for policy makers' vigilance. 


\section{CONDUCT OF MONETARY POLICY WITH}

FINANCIAL STABILITY ISSUES AND A CHALLENGING ENVIRONMENT: THE CASE OF SERBIA Branislav Zoroja

National Bank of Serbia, Monetary Operations Department, General Manager

\section{INTRODUCTION}

I will cover the conduct of monetary policy in Serbia, with regard to our main financial stability concerns.

First, I will explain the inflation targeting monetary framework in Serbia and euroziation as a major financial stability concern. Then, I will touch on the challenging international environment. Afterward, I will try to explain the adjustments in conduct of monetary policy in Serbia and describe some challenges.

\section{INFLATION TARGETING FRAMEWORK IN SERBIA}

Grounds for inflation targeting were introduced in Serbia in 2006, but only in 2009 did we officially run inflation targeting (IT) as a monetary framework, after a memorandum with the government was adopted. In the implementation of the IT framework, standard instruments are used. The key policy rate is our main policy instrument. The key policy rate is, currently, the maximum bid rate applied to the one-week liquidity absorbing repo operations. The key policy rate is complemented by a symmetric interest rate corridor to support the transmission of the key policy rate to money market rates and limit their volatility. We also use required reserves as an important auxiliary monetary and prudential instrument. Indeed, when the reserve requirement ratio is high as it is in Serbia, it can be used as a liquidity buffer in case of some external shocks, under certain stress scenarios. Also, we closely monitor FX market movements, and we are active in the FX market mainly to smooth short-term excessive 
volatility of the exchange rate. One more important supplementary instrument that we use are FX swap auctions. I will explain it later.

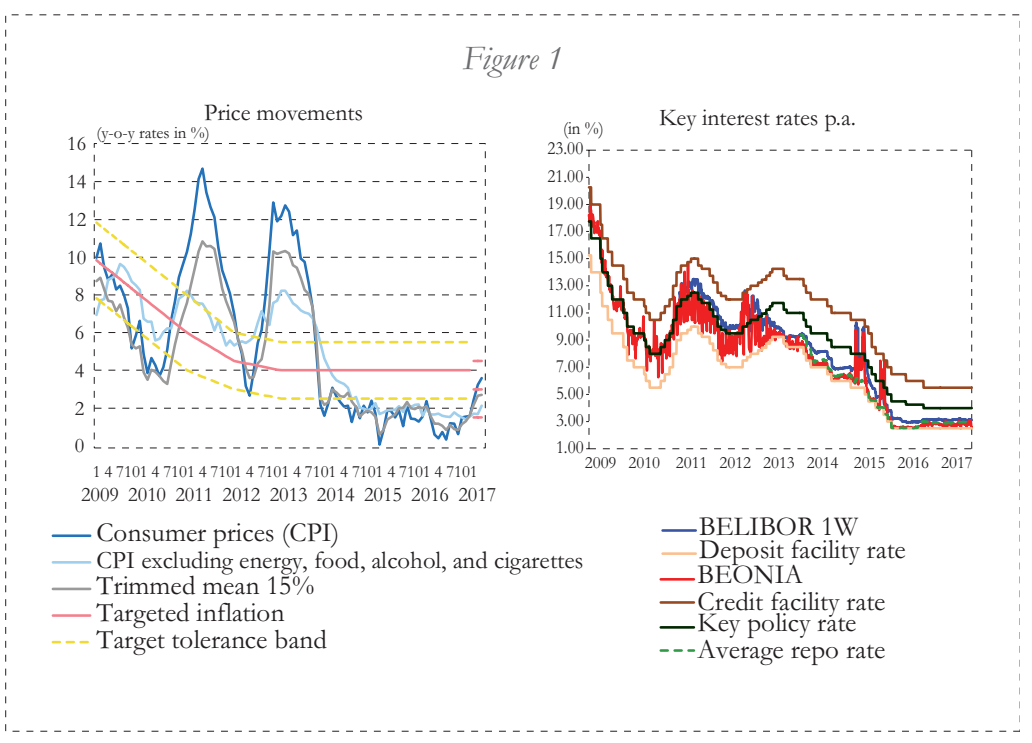

Generally, as you can see in this first graph, from 2013 onwards, we succeeded in lowering and maintaining inflation at low and stable levels. Currently, it stands at 3.6 percent and we expect through 2017 to remain within our target tolerance band set at 3 percent \pm 1.5 percent. On the right hand side of Figure 1, you can see our key policy rate changes and interest corridor movements together with money market rates. We have been in monetary policy easing cycle since May 2013. Up to now, we have decreased the key policy rate by 7.75 percentage points. The key policy rate is currently 4 percent in Serbia.

\section{HIGH EUROIZATION AS A FINANCIAL STABILITY CONCERN}

High and persistent euroization is one of the major financial stability concerns in Serbia. Looking at the figure that shows the share of dinars in banking loans and banking deposits in the private sector, 
on the banking loans side, we can see that the degree of euroization has been steady at about 70 percent over a longer period of time. It moves sometimes up and down depending on the exchange rate movements and some government subsidy programs. On the deposit side, although euroization is even higher, you can see a favorable trend starting from 2012. We had an increase in dinar deposits in the private sector from 19.3 percent in 2012 to 28.8 percent at the end of 2016 (an increase of about 8 to 9 percentage points) that we attribute to a period of macro-economic stabilization in the country, low inflation, and relative stability of the exchange rate, which have contributed to strengthening the confidence in the national currency as a reliable store of value.

\section{Figure 2}
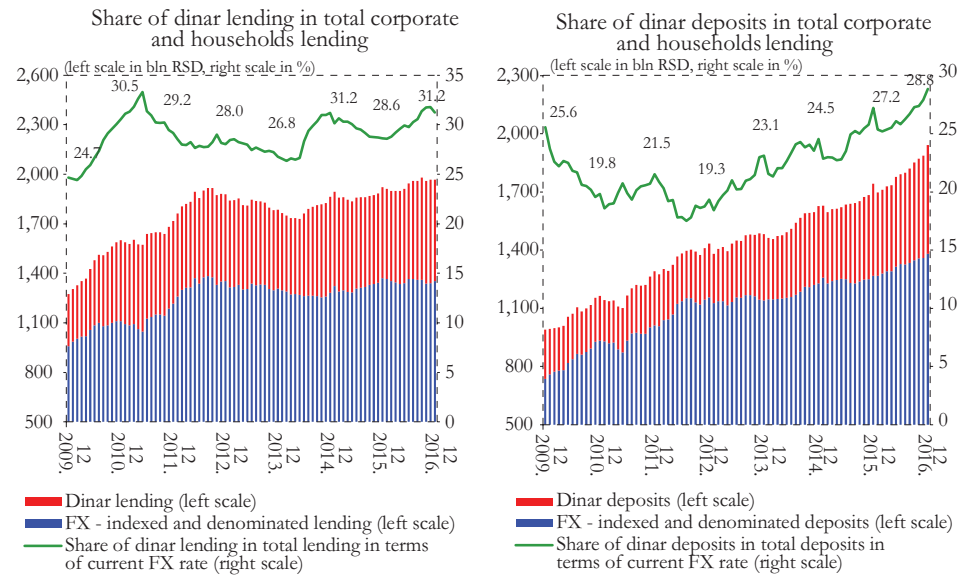

Reasons for the high euroization level in our country stem mainly from a legacy of protracted and acute macroeconomic instability. Serbia experienced hyperinflation during the 1990s that was, at that time, the second largest ever recorded in the world. Hyperinflation was followed by unfavorable geopolitical developments: disintegration of the ex-Yugoslavia, war, sanctions, etc. At that time, monetary policy and fiscal policy were not coordinated, so expansionary monetary policy together with soft budget constrains led to entrenched expectations of persistently high inflation. Very 
soon, as a consequence, an indexation mechanism emerged, with prices linked to exchange rate changes, and only formally published in dinars, a "black" currency market emerged, and trade was performed in foreign currency. Confidence in the national currency was eroded, so that it could hardly fulfill the traditional role of a currency: unit of account, means of exchange, and store of value. Generally, for a long period of time, following this period of acute instability, there was no unique, common approach to restore confidence in the national currency and reduce the use of foreign currency in the local economy. Instead of a common approach shared among and followed by all stakeholders - the central bank, government, and commercial banks - the National Bank of Serbia (NBS) was, in a way, left alone to implement its monetary policy in a highly euroized environment.

So, what is the relationship between euroization and financial stability concerns? In the absence of domestic currency sources of funding, banks started to use foreign currency-denominated sources of funding (domestic or imported) to extend loans to their clients, and because they didn't want to carry FX exposure in their balance sheets, they extended loans in foreign currency or in domestic currency with a FX clause indexing the payment amounts to the exchange rate, thereby, de facto, directly transferring the exchange rate risk to their clients. The clients' exchange rate risk, however, represented a credit risk for the banks because of debt servicing capabilities of unhedged borrowers; corporates and households started to be very sensitive to sharp exchange rate movements. Over time, after a few episodes of sharp currency depreciation, the problem with non-performing loans (NPLs) has arisen. Recently, NPLs have been treated as a major financial stability concern, and that's why two years ago the government and the NBS together adopted a NPLs resolution strategy as a set of measures to tackle the problems of NPLs. Currently, NPLs are about 17.4 percent of total loans, lower by approximately 4 percentage points compared to 12 months before. Therefore, although still high, NPLs are on a decreasing path.

The NBS runs a "managed floating" exchange rate regime, which should provide adjustment to the economy via the exchange rate in case of some external shocks, so that the burden of adjustment 
can be transferred across the economy. Such potential advantage of the managed floating exchange rate regime is undermined in the context of high euroization rates as it cannot be used in full capacity due to financial stability concerns. That accentuates the importance of exchange rate movements from a central bank's perspective. It requires a more active role of the central bank in the FX market in order to minimize excessive exchange rate fluctuations and provide relative exchange rate stability within narrow boundaries.

Regarding monetary policy implications, because the share of domestic currency in the financial system was just about 30 percent, it forced us to keep policy rates very high over a longer period of time, and have major changes in its level to be effective enough to transfer to the money market interest rates. Otherwise, the interest rate channel would not have functioned efficiently. The effectiveness of the interest rate transmission channel was, therefore, partially undermined by the degree of euroization and had to take into account any possible indirect effect of changes of interest rates on the exchange rate and, eventually, on the debt servicing costs of unhedged borrowers. Changes in the key policy rate are primarily determined by the changes of interest rates in the euro area. During periods of downward pressure on the dinar exchange rate, monetary policy had to take into account the risk of possible increase in NPLs, and use FX interventions to prevent significant depreciation.

Even in tranquil times, much like now (low inflation and weak economic growth), the possibility of using some central bank instruments to promote credit activity may be limited because of high euroization. For example, stimulating credit activity by diminishing required reserves ratios may not be so efficient if banks are already burdened with high levels of NPLs. That would prevent them from further credit activities against risky borrowers, such as corporates and households, and point them to safe assets.

\section{CHALLENGING ENVIRONMENT}

Small, open economies with a still significant pass-through of exchange rate changes to inflation, such as Serbia, are very careful 
about global capital movements. Among various things, we particularly follow actions of the central bank of the largest economic areas, the ECB and the US Fed. And I will just comment that the Fed quantitative easing (QE) exit and more restricting monetary policy have had significant effects in portfolio outflows from Serbia, mainly from our domestic currency government bonds, because US funds were major investors in these bonds. Actually, Serbia attracted these investors in the Serbian government debt market during the Fed QE programs. When these flows were reversed, we had to cope with the exit of some investors and the resulting depreciation pressures on the currency.

On the other hand, the ECB negative rates and the asset purchase programs - that put plenty of euro area liquidity on markets - have not had significant portfolio inflow effects on our country. We have not seen so visible and direct exchange rate effects, although significant incentive to lending emerged because of low interest rates, which also significantly contributed to ease debt servicing costs and to put NPLs on a downward trajectory.

I will shortly mention some spillovers of euro area negative rates to our economy. Regarding financial stability, we didn't see excessive risk-taking from banks in Serbia. So far, we have not seen even desirable risk-taking, because banks are risk-averse, and hesitant to invest in the private sector because of high NPLs. They prefer investing in government bonds that are risk-free and attractive due to higher interest rates. We have not seen cash substitution either (withdrawing savings from banking sector), despite very low interest rates on FX, even though, we tend to have a high propensity for keeping money "under the "mattress."

Serbia has continued enjoying growth in FX savings since the introduction of negative euro area interest rates and the launch of the asset purchase programs. We have not experienced currency substitution on the deposit side either (FX currency savings being converted to dinar currency), although that would be desirable from the deeuroization perspective. 
On the other hand, negative euro area interest rates posed serious challenges to NBS FX reserve management. The traditional principle "security comes first" led to negative yields from the investment of NBS FX reserves in euro-denominated assets, and placement of euro reserves operationally became much more demanding because of preset timelines, new rules for charging penalty rates by first-class international counterparties, etc. We experienced a period when banks tried to transfer the cost of negative rates to our central bank by allocating euro funds over required FX reserves in our system. In response to that the NBS introduced a penalty rate on banks, FX holdings beyond mandatory reserve requirements, and offered banks the opportunity to place funds with central bank accounts under a contract that would enable them to get the same yield for the funds that the NBS gets in international markets. Also, there is a question of volatility of our FX reserves because our intervention currency is the euro and under our required reserve instrument, full averaging is allowed. That could put FX reserve management under pressure to hold more euros on sight deposits and induce more costs.

\section{ADJUSTED CONDUCT OF MONETARY POLICY}

Financial stability and a changing market environment had significant effects in designing and adjusting monetary policy instruments in Serbia. Here, I am going to concentrate on a few adjusted instruments designed specifically to promote domestic currency.

First, in collateral policy, only securities issued in domestic currency can be used for open market operations and credit facilities. Currently, only government bonds and some international bonds issued in dinars are available.

Second, required reserve rates are set in such a way as to stimulate both longer term and dinar sources of funding and to discourage shorter-term and FX sources of funding. For example, currently the required reserve rate for short term FX sources of funding in our country is 20 percent and 0 percent for longer term and dinar sources of funds. Also, remuneration in required reserve policy is used to stimulate domestic sources of banks' funding: the domestic 
currency required reserve is remunerated and $\mathrm{FX}$ required reserve is not. Colleagues from the IMF correctly noted that even a 0 percent remuneration rate for the FX (euro required reserve) in the international environment means subsidizing banks because of the negative euros area interest rates. As mentioned before, banks in Serbia were trying to deposit euro at the NBS in excess of the reserve requirements, so, in 2014, we introduced a penalty rate for banks holding FX funds in excess of the required reserves.

Third, as I explained before, the NBS had to be more involved in the FX market to lower short-term exchange rate oscillations. That is why the NBS invested a lot of effort in market-monitoring in previous periods. This investment in market-monitoring capabilities allow us to provide quality information to decision-makers to increase the efficiency of our FX interventions, that is, to be able "to achieve more with less." The NBS interventions are performed on both sides of the market. We are not price makers but price takers, and we believe that, in this phase of our development, it is important to provide together low inflation and relative exchange rate stability with the aim of promoting deposit dinarization, which would in turn enable and encourage loan dinarization.

Finally, the NBS also uses FX swap auctions as a supporting tool to provide banks with an additional liquidity management instrument, to support the development of the interbank swap market, and to support banks to overcome internal trading limits with other banks.

\section{CHALLENGES}

I will try to conclude by providing some lessons that we learned and possible challenges in Serbia.

The NBS prefers using market incentives rather than the adoption of administrative measures. The region has already suffered a lot from Swiss franc mortgage loans and, in some countries, FX loans to households are forbidden, and some central banks provided conversion in other currencies, while the NBS did not use any administrative measure. We still prefer using market incentives in the first place. 
Unilateral euroization is not an option for Serbia. In light of our economic competitiveness, internal and external imbalances, and financial system vulnerabilities, adopting the euro at the present juncture could be rather detrimental for the economy, and not beneficial. The aim of Serbia is to adopt the euro ultimately, as a member of the EU and after all convergence criteria are met.

In our opinion, the de-euroization process is a kind of a marathon, not a sprint race. We see it as a long road that needs to be crossed with a series of small steps. In this phase, we consider that "deposit de-euroization" is the key. Higher deposits in domestic currency would later provide ground for higher lending activity in domestic currency.

We insisted on improving macroeconomic fundamentals in good times and doing structural reforms to build buffers against external shocks in bad times. The government put a lot of effort into the past three or four years to lower the fiscal deficit and to implement structural economic reforms that contributed to a more favorable business environment in Serbia, upgrades by major rating agencies, and improving external imbalances. Also, it was beneficial for implementing monetary policy in Serbia. The challenges for the future are to be persistent in providing good macroeconomic results, to persevere with our policies to deliver good results over a long period of time.

Last, but certainly not least, there is a need to invest more effort in general financial literacy and education of the public. Specifically regarding market risks (exchange rates and interest rate risks), to which the most sensitive parts of the economy - households and corporates - are exposed, there is more to be done to raise public awareness and understanding. Only properly understanding these risks can enable protecting against them. Education is an important part of financial market development, because the public needs first to understand the main market risks, and only then would people and corporations start thinking about the hedging against them. 
This page intentionally left blank 


\section{CONCLUDING REMARKS}

Miguel Savastano

International Monetary Fund, Monetary and Capital Markets Department,

Deputy Director

I would like to thank all the participants for the presentations and for the discussions that we have had. I said yesterday that I was looking forward to learning from all of you, and I can report to you that I have indeed learned a lot and I hope that each of you has learned as well.

I am a soccer fan, I like soccer. And, at the end of conferences like this, I always feel the way I feel at the end of the first week of the soccer World Cup: I know I have watched many games, but I don't quite remember which teams I have seen and which plays I liked. It's all mixed up. Something similar happens at the end of conferences like this: there is information overload. But, as well as in the world of soccer you can watch the replay, in a conference like this, you can always go back and read the Power Point presentations, the notes you have taken, and the proceedings.

So, I encourage you to do that in the next few days, if you have time, and try to draw from those the main takeaways, the main conclusions you got from the four or five main dimensions of spillovers from negative interest rates in the euro area that have been discussed over the past couple of days. I have a few tentative takeaways that I would like to share with you, but like at the end of that first week of soccer games, they are not very clear, they are not conclusions, they are not a summary or interpretations, but just my preliminary takeaways to give you some more things to think about.

The first one has to do with what you call here, appropriately, "euroization," prevalent in the Western Balkans, and developments related to the interplay between that process and financial stability. 
The first point is a very general point: what to do with euroization in those economies that have a partial euroization process going on. There are two extreme attitudes: one is total indifference and the other is obsession.

None of the two extremes is correct to approach partial euroization. So, central bankers and policymakers need to strike a balance between denial, neglect, or total indifference on the one hand and obsession with how to undo it on the other hand. Now it turns out that striking a balance between financial and monetary objectives is not in the DNA and should not be in the DNA of central bankers. Central bankers are encouraged to be obsessed about maintaining inflation low and stable and about preserving financial stability. I encourage central bankers to remain obsessed about that, but, in the spectrum between obsession and indifference about this issue, I will encourage central bankers to be further away from obsession in the issue of how to deal with partial euroization. This is my first takeaway.

The second takeaway is related to the first one. It has to do with the time horizon over which partial euroization should be considered a concern.

I think that clarity about the horizon over which macroeconomic or financial variables respond to shocks and the horizon over which policies to mitigate the effects of the shocks are relevant is one of the most common casualties of policy discussions.

The same happens in conferences like this. We tend to focus on the sign of a given phenomenon: if it has a positive effect or a negative effect or a neutral effect. There are many reasons it is like that. Take the issue of partial euroization. We have heard many times over the past two days that partial euroization seems to have negative effects and seems to negatively affect the effectiveness of the monetary policy. That's one effect. We have heard less that partial euroization also increases the risk to financial stability.

Over what horizons are these two problems relevant? Are these short-term issues, should they be short-term concerns, both of them, 
or are they medium-term concerns, are they long-term concerns? It's different depending on the problem you focus on.

The problems that euroization causes for the conduct of monetary policy cannot be mitigated over a short term. It is more of a mediumterm issue. So, we have to deal or cope with the issue that there is a partial euroization and we should remain focused on achieving the low and stable level of inflation despite the partial euroization. At the same time, one should try to adopt measures that are long-term to ease the consequences of partial euroization or contain it.

We just heard one of the colleagues mentioning that it is a marathon, and I would agree with that. I would just add that there is not just the marathon of the next Olympics, but there are the marathons of the next three Olympics. It is a long-term horizon over which addressing partial euroization should be an objective. It's a matterof-years issue, it's not a matter-of-quarters issue.

How about the effects of euroization on financial stability? That's completely a different horizon. That is a short-term problem. That is a near-term issue. Protecting and preparing the economy for negative shocks in an economy where the balance sheets are partially euroized, should be the main concern of all central bankers and authorities, even though the euroization or the partial euroization is not going away.

So, this risk or this vulnerability brought by partial euroization is the main reason I said at the beginning that the concern of the central bankers should be further away from obsession on partial euroization but not all the way to the denial and neglect. You cannot ignore that the balance sheets of an economy partially euroized are weak and are subject to shocks of many types. They will be aggravated by the fact that you have all these mismatches lying on those balance sheets of banks, of the government, and of households. When there is a downturn or a shock, that can take many shapes and forms and has happened in many countries; the outcome is invariably negative, and that is not the time to start preparing to mitigate the effects. You must be prepared beforehand. 
The third takeaway is also related to the discussion of the past two days. We have heard that there are no differences between low interest rates and negative interest rates. The traditional policy rate effects continue unfolding when interest rates turn negative. Everything is fine and smooth. Perhaps, indeed, this is the case for monetary policy, which was the focus of the presentations. One aspect that was not discussed, because it was not the subject of this conference, is that at the same time that negative interest rates have exerted some effects for monetary policy in the euro area and in Switzerland and have had spillovers on monetary policy for all the countries including the Western Balkans, they have also increased systemic risk both in the center, in the euro area, and in the periphery. So, the systemic risk in a low interest rate environment has increased. That's true and there is enough evidence to show that this is the case.

This increased systemic risk is aggravated by two factors that are specific to emerging markets and to the Western Balkans: one is the ownership of the banks and the other is the partial euroization or the mismatch of the balance sheets. I talked about partial euroization so I will not get into that, but let me talk about ownership of the banks. Banking systems in emerging markets, like your region, are very different from the banking systems in advanced economies, not just because of the size or the number of banks, but also because of the ownership structure of the banks. In most advanced economies, all banks are private businesses, private banks, small, medium, large, mostly privately owned. You go to emerging markets and you have three types of ownerships: you have private domestically owned, foreign private banks, and government-owned banks. In addition to that, you have fewer banks. So, the presumption that whatever works in terms of financial stability and resolution and activity in the euro area or in the US applies directly and without a matter of thought to emerging market is a wrong presumption.

The same goes for using and having a false sense of security for traditional indicators such as a small leverage of households, natural hedges, lower NPLs. All these are nice in a crisis; however, in crises, as we have seen, it does matter also what type of relationship exists between the branches of the foreign banks and the parents of the foreign banks. Most countries have found too late that what they 
thought was going to happen didn't happen, especially regarding the expected support that foreign banks would provide to their local subsidiaries. This means that you must not assume, but prepare. Check with your foreign banks what is the exact presumption or agreement, what would happen if the event materializes in your country or the rest of the world. It doesn't have to be your country; it can be a neighbor country, it can be in the region.

Complacency about the risk to financial stability is the biggest risk for a central bank. When it comes to identified tail risk or extreme event risk, there is no middle ground here between a central bank not being indifferent to systemic risk and being obsessed. It must be obsessed to anticipate to the largest possible extent tail risks, and it must prepare a strong resolution framework for extreme events.

I have seen this in other parts of the world in different attempts. I've seen countries come and say: we fully adopted the dollar and this will protect us completely against financial crises, and I saw those countries undoing full dollarization because they had to. In an extreme event, that can happen; the presumption that the reserves were covering all possible events may not hold. When liquidity assistance needs to be provided to banks beyond the level of reserves held, in a foreign currency you cannot issue, you have to issue something else, and if that doesn't contain the damage of the negative shock and the foreign-owned parent banks don't give liquidity to the local banks, then, you have to do something with their banks.

So, you truly must be prepared and, in some cases, I have seen it more than once, financial stability risks materialized because the authorities were adopting not very prudent policies, and in other cases, it was just a bad combination of external shocks. So, the bottom line of all this is to bring the issue of financial stability as an additional dimension to the negative interest rate environment and apply it to your own countries. 
This page intentionally left blank 


\section{SPEAKERS' BIOS}


This page intentionally left blank 


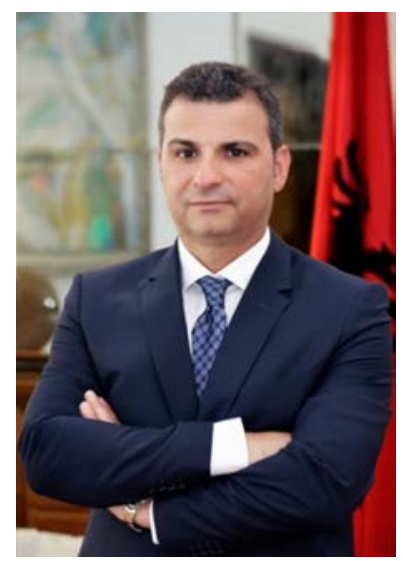

GENT SEJKO

Governor Bank of Albania

Mr. Gent Sejko is the Governor of the Bank of Albania and Chairman of its Supervisory Council as of February 2015. He was voted in as Governor by the Parliament of the Republic of Albania on February 5, 2015, upon the Decree of the President of the Republic of Albania.

Mr. Sejko graduated from the Faculty of Economics, University of Tirana, in 1991, in Industrial Economics. He earned a Master's Degree in International Accounting and Financial Management (MAcc) from the University of Glasgow, Scotland, in 1997, with his thesis on the "Role of banks and privatisation of banks in economies in transition."

Mr. Sejko started his banking career in 1992 as Head of the Credit Division of the National Commercial Bank. Then he worked as an Inspector at the Supervision Department of the Bank of Albania until 1998 while pursuing his post-university studies. During 1998-2000, Mr. Sejko worked for Deloitte \& Touche as Senior Auditor and Consultant, responsible for the management of audit procedures. In the years 2001-2002, he worked for the American Bank of Albania as Head of Internal Audit and Compliance Division, and engaged in extending the branches network of the bank.

During 2002-2004, Mr. Sejko returned to the Bank of Albania's Supervision Department as Head of the Division for on-site examinations.

In the period 2004-2010, he held a number of managent positions at Raiffeisen Bank such as Head of the Division for the Internal Audit, Compliance and Relations with the Government, Director General of Raiffeisen Leasing, and Head of Corporate Banking. He also served as a Member of the Credit Committee, Member of the Assets \& Liabilities Management Committee, Member of the Supervisory Council of Raiffeisen Leasing, and Member of the Supervisory Council of Pension Funds.

From July 2010 to February 2015, Mr. Sejko was the Deputy General Manager and Head of Retail Department and Branches Network for "Société Générale Albania." In addition, he served as a Member of the Assets \& Liabilities Committee, Member of the Supervisory Council of SG Leasing, and Member of the Credit Committee of the Bank. 


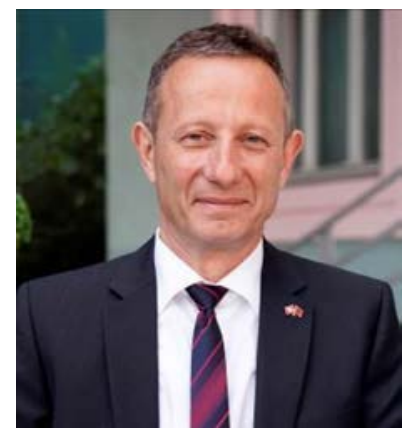

DR. CHRISTOPH GRAF

Ambassador of Switzerland in Albania

Dr. Christoph Graf has been the Swiss Ambassador to the Republic of Albania in Tirana since September 2014. He has 25 years of experience related to international policy and development cooperation.

Before his current assignment in Albania, Dr. Graf served as Deputy Head of the Department Global Cooperation of the Swiss Agency for Development and Cooperation (SDC) in the Swiss Ministry of Foreign Affairs in Berne, Switzerland. He was responsible for development policy issues, the dialogue with multilateral institutions, and the implementation of thematic Global Programmes such as climate change, food security, water, and migration.

Earlier he was posted for the Swiss Government as Regional Director of Cooperation for Central America in Nicaragua. Then he headed the Evaluation and Controlling Unit of SDC, and directed the South Asia Division in Berne, in charge of the cooperation programmes with Afghanistan, Pakistan, India, Nepal, and Bangladesh, and of the policy development in the field of conflict, fragile contexts, and human rights.

Before joining the Swiss Ministry of Foreign Affairs, Dr. Graf studied Geography and Economics at the University of Zurich, worked for the Swiss banking sector, and carried out consultancies for the business sector in Europe. 


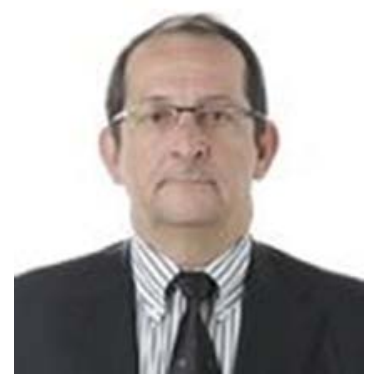

MIGUEL SAVASTANO

Deputy Director

Monetary and Capital Markets Department

International Monetary Fund

Mr. Miguel Savastano is a Deputy Director in the Monetary and Capital Markets Department of the International Monetary Fund (IMF). In this capacity, he oversees the advice provided by the IMF to its member countries on resolution of banking sectorproblems. Prior to this, he was a Deputy Director in the Western Hemisphere Department, and before that, he had assignments in the Middle East and Central Asia Department, the Finance Department, the Policy Development Department, and the Research Department.

Mr. Savastano has published extensively on macroeconomic issues of relevance for developing countries, especially in Latin America. He is a member of the American Economic Association and has been Associate Editor of scholarly journals, including the Journal of Development Economics and IMF staff papers. 


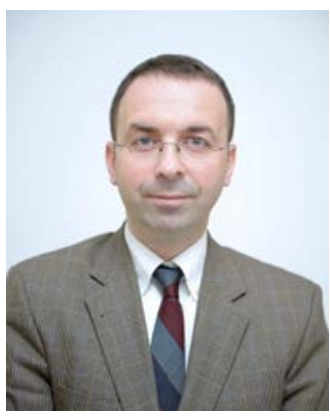

KLODION SHEHU

Director

Financial Stability Department

Bank of Albania

Mr. Klodion Shehu holds a Bachelor's Degree in Finance/Banking from the University of Tirana, and in 2013 he completed an Executive MBA at City College, International Faculty of University of Sheffield.

Mr. Shebu has held various job positions in the Bank of Albania, since November 1995. He first started to work as an on site examiner in the Supervision Department, and then moved into the Monetary Operations Department, where he initially was in charge of foreign currency operations and then was promoted to Deputy Director of the department, monitoring all the monetary operations of the Bank of Albania.

In the summer of 2003, he started to work as the Director of the Supervision Department, in charge of regulation and supervision of banks and some non-bank. financial institutions, licensed by the Bank. of Albania. In September 2007, Mr Shebu was appointed as the Director of the then newly established Financial Stability Department, with the task of organizing the work of the department and developing the necessary methodologies for the assessment of systemic risk, and later on for the design of the macro-prudential framework. in the Bank of Albania.

Since 2012, he has headed the Secretariat of the Financial Stability Advisory Group, an inter-institutional forum that regularly reviews systemic risk. developments in the financial system. From the beginning of 2016, he has also represented the Bank. of Albania on the Board of the Financial Supervision Authority. 


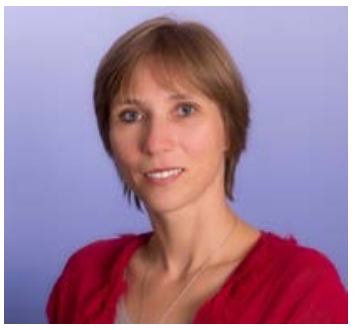

JULIA WOERZ

Head of the Central, Eastern and Southeastern European Analysis Unit

Foreign Research Division

Oesterreische Nationalbank

Dr. Julia Wörz is Head of the Central, Eastern and Southeastern European Analysis Unit at the Foreign Research Division (Economics Analysis and Research Department) of the Oesterreichische Nationalbank (OeNB) and Equalities Officer.

Her main responsibilities are coordinating the OeNB's economic analysis and monitoring activities concerning Central, Eastern and Southeastern European countries and providing in-depth analysis of trade and competitiveness related issues. In addition to her duties at $\mathrm{OeNB}$, she is teacbing international economics at the University of Innsbruck.

Prior to joining the OeNB in May 2008, she had been Staff Economist at the Vienna Institute for International Economic Studies (wiiw) since 2001. At the wiin, she was involved in various research projects and coorganized a range of workshops as well as the biweekly wïw seminar series on "International Economics."

Dr. Wörz holds a Doctoral Degree in Economics from the University of V ienna and received the venia docendi from the University of Innsbruck in 2012. Her main research interests are European economic integration, economic convergence, competitiveness, international trade, globalization and global value chains, long-run determinants of economic growth, and macro-economic forecasting.

She has co-authored numerous scientific articles published in peer-reviewed journals, for example in Economics of Transition, Empirica, Journal of International Economics, Weltwirtschaftliches Archiv / Review of World Economics. Dr. Wörz is a member of the Scientific Committee of the European Trade Study Group and Scientific Coordinator of the Focus on European Economic Integration (FEEI). She was appointed Equal Opportunity Officer at the OeNB in 2014 and has been an elected member of the OeNB's Staff Council since 2013. 


\section{ROMAIN VEYRUNE}

Senior Economist

Monetary and Capital Markets Department International Monetary Fund

Mr. Romain Veyrune is a Senior Economist in the Central Banking Operations division of the Monetary and Capital Market Departments of the International Monetary Fund (IMF). He joined the IMF in 2005. From 2012 to 2014, he was Market Operations Expert in the Money Market and Liquidity Division of the Directorate General Market Operations of the European Central Bank. His main interest is in exchange rate and monetary policy design and implementation. He co-authored the IMF working paper "Dedollarization," WP/10/188. 


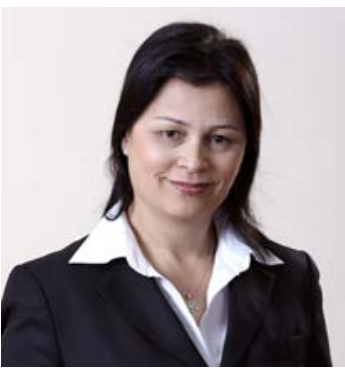

DR. NATASHA AHMETAJ

Second Deputy Governor

Bank of Albania

Dr. Natasha Abmetaj is the Second Deputy Governor of the Bank of Albania since May 6, 2015, and has been a member of the Supervisory Council of the Bank of Albania since December 2014.

She graduated in 1987 from the Faculty of Economics, University of Tirana as an economist for the industry sector. She earned a Master's Degree in Economy in 2000 and Doctor of Sciences in Economy in 2004, from the same faculty.

She started herprofessional carrer in her hometown, initially working as an economist of Plan and Cost during 1987-1994 at the Navy Repair Plant. In 1994, she started her academic career. In the period 1994-2001, she was a Professor/Lecturer of "Macroeconomy," "Microeconomy," "Monetary economy," and held the position of the Head of Business Department and later of the Dean of Trade Faculty, at the Public University "Ismail Qemali," in Vlora.

In 2001, she was appointed Director of the National Commercial Bank. (BKT), Vlora Branch, while she continued to be a part-time lecturer. Since 2001, Dr. Abmetaj has advanced her career, starting with the position of the Head of the Marketing Department of the Head Office of BKT, during 2002-2007, and later as Administrator of the BKT. She held this position from 2008 till her election as a member of the Supervisory Council of the Bank of Albania.

During ber long career, Dr. Abmetaj has received many academic and scientific qualifications and trainings from renowned academic and financial institutions.

Dr. Abmetaj is the author of many scientific research articles and publications focusing on various economic and financial issues. 


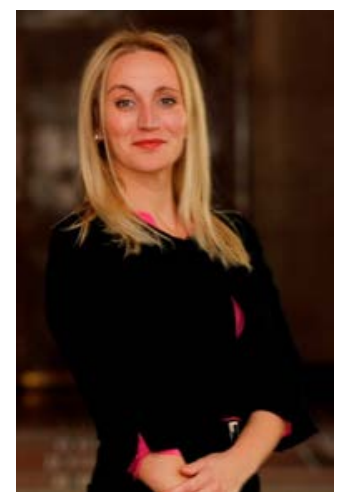

BELMA ČOLAKOVIĆ

Chief Economist

Central Bank of Bosnia and Herzegovina

Dr. Belma Colaković has over 15 years of central banking experience. Dr. Colakovic currently bolds the position of Chief Economist in the Office of the Chief Economist, which she established in 2013. Her earlier posts with the Central Bank of Bosnia and Herregovina (CBBH) included that of Head of the Financial Stability Department, where she developed the first macroeconomic, top down stress testing framework for Bosnia and Herzegovina and wrote the first Financial Stability Report of the CBBH. She was also professionally exposed to academia, both as a lecturer and as an external journal reviewer.

Dr. Colakovic holds a Ph.D. in Economics from the Staffordshire University, an $M A$ in Economics from the University of San Francisco, and a BA in Economics from the University of Sarajevo. 


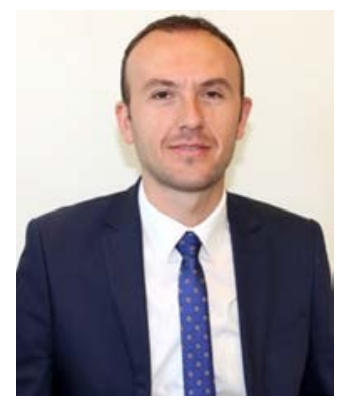

\author{
ARBEN MUSTAFA \\ Advisor to the Governor \\ Central Bank of the Republic of Kosovo
}

Dr. Arben Mustafa graduated in the field of Banking and Finance at the Faculty of Economy of the University of Prishtina in 2005. One year later, he finished his MSc studies in Economics for Business Analysis at the Staffordshire University in the United Kingdom. At the same University, in 2014 he finished his Ph.D. studies on the topic "Banking Sector Competition and Its Impact on Banks' Risk-Taking and Interest Margins in the Central and East European Countries"

Since 2007, Dr. Mustafa has been working at the Central Bank of the Republic of Kosovo, where he joined the Financial Stability and Economic Analysis Department initially as an Economist. In 2009, he was promoted to the position of the Director of the Department and exercised this function until end-2016, when he shifted to the Cabinet of the Governor as Advisor for Financial Stability and Macroeconomic Developments. 


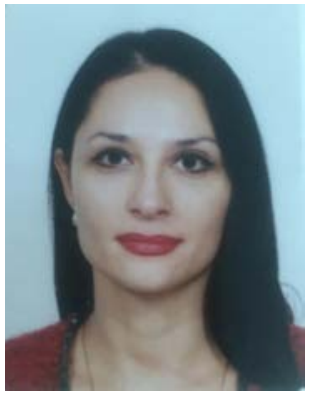

MILENA VUČINIĆ

Special Advisor

Financial Stability Department

Central Bank of Montenegro

Ms. Milena Vucimic graduated in 2007 at the Faculty of Economics of the University of Montenegro in Podgorica, where she is currently enrolled as a Ph.D. student. She earned her Master's of Science in Economics on "Comparative Analysis of Financial Stability of Montenegro and Chosen Countries" at the Faculty for International Economics, Finance and Business, at University of Donja Gorica in Podgorica. She earned an Associate Degree at American College of Management and Technology of the Rochester Institute of Technology in Dubrovnik.

Ms. Vucimic started her professional career in 2004 since she was a student as a full time employee in the Economics Department in the Broadcasting Agency of Montenegro. Over the period July 2007 to February 2011, she was employed as a Project Manager at Montenegrin Investment Promotion Agency (MIPA) of the Government of Montenegro.

From February 2011, she was employed by the Central Bank of Montenegro. Since March 2015, she beld the position of Special Advisor for Financial Stability Issues to the Director of the Department for Financial Stability, Research and Statistics. Prior to this, she was a Director of Directorate for Public Relations (September 2013 to March 2015); Head of Protocol Division (June 2011 to September 2013); Senior Advisor in the Division for Cooperation with International Financial Organizations (February 2011 to June 2011). 


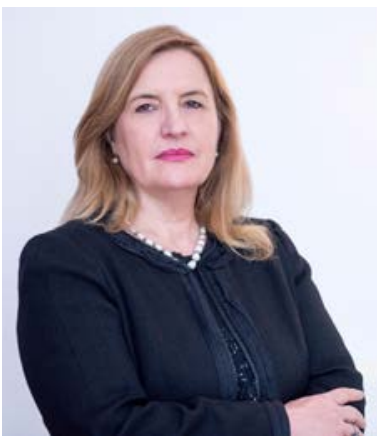

\section{ELISABETA GJONI \\ First Deputy Governor}

Bank of Albania

Mrs. Elisabeta Gjoni is the First Deputy Governor of the Bank of Albania as of January 2012. She is also a member of the Supervisory Council of the Bank of Albania as of November 2011.

Before taking this position, Mrs. Gjoni had an extensive career in the financial sector and in its regulation. She served as Chair of the Albanian Financial Supervisory Authority from the establishment of the institution in 2006 until December 2011. Earlier, she served in the securities sector as Chair of the Albanian Securities Commission. Mrs. Gjoni has been a member of the Supervisory Board of the Bank of Albania for eight years and Deputy Governor of the Bank of Albania during 1995-1997. She acted as Alternate Governor for Albania at the EBRD, Financial Advisor to the President of the Republic of Albania in 1992-1996, and a member of the Negotiation Committee on Foreign Debt. She enriched her already broad experience while working in the private financial sector for the Albanian-American Enterprise Fund.

An extensive academic career followed her graduation as an Economist on Finance from the University of Tirana in 1982. She was a full-time lecturer on financial management during 1982-1992 and is currently a visiting professor of finance and economy at the University of Tirana and other universities in Albania. Mrs. Gjoni is the author of studies, articles, and research papers on finance, economic policies, banking, capital markets, etc.

In addition to her valuable contribution to the financial sector in Albania, Mrs. Gjoni is actively helping people in need, especially children. She is a board member of the Albanian Children Foundation, a not-for-profit organization devoted to poverty reduction and assistance to the Albanian children in need. She is also a member of the Friends of the National Gallery of Arts. 


\section{ROBERTO DE BEAUFORT}

Lead Financial Officer

World Bank

Mr. Roberto de Beaufort joined the World Bank. Treasury in 2003 as Lead Financial Officer of the Reserves Advisory and Management Program (RAMP), responsible for managing the technical assistance program for central banks and sovereign wealth funds of member countries.

Before joining the World Bank, Mr. de Benafort worked at the Banco de la Repuiblica of Colombia during 21 years as a Portfolio Manager, Chief Porffolio Manager, and Director of the Foreign Exchange Reserves Department. He was also responsible for the management of the Oil Stabilization Fund of Colombia.

Mr. de Beaufort holds an MA in International Relations from the Southampton University, United Kingdom. He has also written many articles on reserve management in several central banks' journals and was responsible for the annex on Colombia of the Accompanying Document to the Guidelines for Foreign Exchange Reserve Management of the International Monetary Fund. 


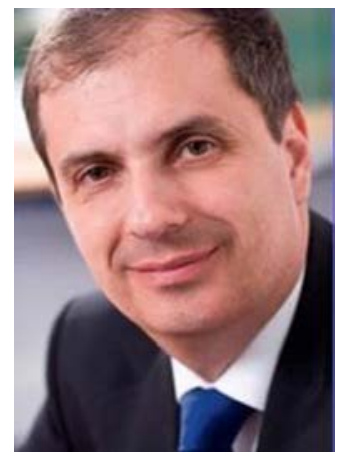

VICTOR ANDREI

Director

Market Operations Department

National Bank of Romania

Mr. Victor Andrei is Director of the Market Operations Department at the National Bank of Romania where he is in charge, among other matters, of the foreign reserves management.

He has more than 20 years' Treasury experience, having held senior positions in both public (Central Bank) and private (Citibank Romania and private equity) companies. 


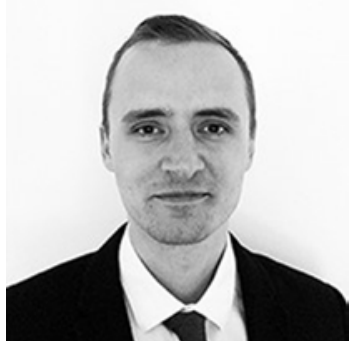

SÁNDOR LADÁNYI

Risk Analyst

Directorate Monetary Policy Instruments,

FX Reserves and Risk Management

Magyar Nemzeti Bank

Mr. Sándor Ladanyi, CFA, is an Investment Strategist at the National Bank of Hungary (MNB). He is currently responsible for the investment strategy of the country's foreign exchange reserve.

He first joined the Risk. Management Department of MNB in 2014 and worked on the development of the risk management framework. Prior to joining the central bank, he worked at Morgan Stanley, performing valuation reviens on interest rate products.

Mr. Ladanyi earned his Master's Degree in Economics at the Corvinus University of Budapest in 2012. After graduation, he completed the CFA Program and was awarded the charter last year. 


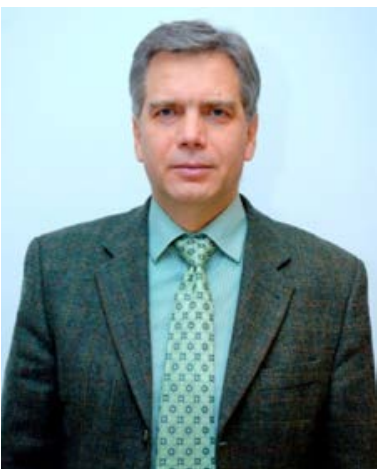

\section{MARIAN GJERMENI}

Director

Monetary Operations Department

Bank of Albania

Mr. Marian Gjermeni started to work at the Bank of Albania since its establishment in 1992. In 1996, he was been appointed the Head of the Monetary Operations Department. In this position, he has overseen a number of issues related to money, exchange rate, and securities market, implementation of the monetary policy, investment of foreign reserves, as well as the relations between the Bank of Albania and the Ministry of Finance. Mr. Gjermeni has been also involved in the negotiation of the foreign debt of the Republic of Albania.

He is currently a member of several committees such as the Committee on the Implementation and Advising of the Monetary Policy, Committee on the Investment of the Foreign Exchange Reserves, Committee on the Liquidity Administration and the Domestic Debt between the Bank of Albania and the Ministry of Finance, as well as a member of the Advisory Committee on Financial Stability.

Mr. Gjermeni holds a Bachelor's Degree in Finance from the University of Tirana and a Master's Degree in European Economic Studies from the University of Tirana and the University of Bamberg. 


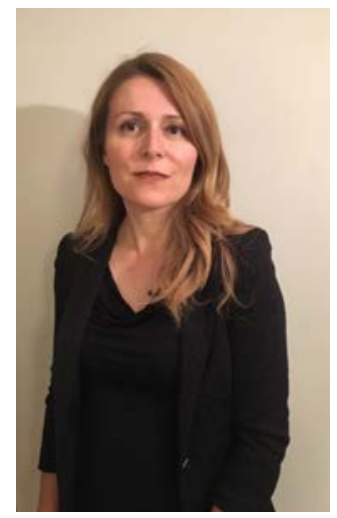

\section{VESNA HRISTOVSKA}

Manager

Financial Market Operations Department National Bank of the Republic of Macedonia

Mrs. Vesna Hristovska has 20 years' experience in banking and has held the position of Manager of the Financial Market Operations Department in the National Bank of the Republic of Macedonia since 2011. She has been involved in foreign exchange reserves management, monetary policy implementation, issuance of government securities, interventions on foreign exchange market, and domestic banks' liquidity management.

Mrs. Hristouska actively participated in many projects in the National Bank of the Republic of Macedonia, focusing on the development of financial markets in Macedonia, the improvement of the monetary policy operational framework, as well as building the institutional capacity for management of foreign exchange reserves. She is project manager for the World Bank RAMP program, where the National Bank has been participating since 2014.

Mrs. Hristovska is a full member of the central bank's Investment Committee, and also of the Asset and Liability Management Committee and of the Committee for Operational Monetary Policy.

Mrs. Hristovska holds a Master's Degree in Instruments of Financial Markets. 


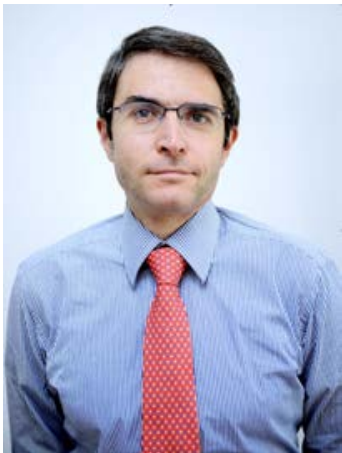

GUIDO DELLA VALLE

Monetary Policy Advisor to Bank of Albania Monetary and Capital Markets Department International Monetary Fund

Mr. Guido Della Valle has been IMF's Monetary Policy Advisor to the Board of the Bank of Albania since January 2016. During this period, he has advised the Bank of Albania on a wide range of monetary policy design and implementation issues, including the estimation of the lower policy rate bound and the development of a de-euroization strategy. Previously Mr. Della Valle worked over 15 years at the European Central Bank as Principal in the Directorate General Market Operations, initially focusing on FX reserve management and thereafter on the monetary policy implementation, where he contributed to the design, implementation, and assessment of several non-standard monetary policy tools.

Mr. Della V alle has co-authored several IMF W orking Papers, including a Working Paper on the estimation of the lower bound in a euroized economy and another Working Paper on the development of a euroization strategy in Albania. He also contributed to several ECB Economic Bulletins articles. He holds lectures at universities, including a recent seminar at the Centre of Excellence in Finance on Deepening Money Markets and Promoting the Use of Local Currency Instruments. He holds a Master's in Business Administration from Hull University and a Bachelor's Degree in Economics from the University of Venice. 


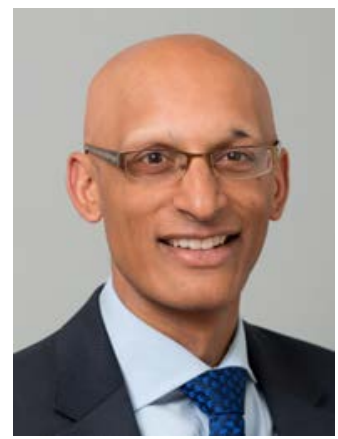

RYAN BANERJEE

Senior Economist

Monetary and Economic Department

Bank for International Settlement

Dr. Ryan Banerjee is a Senior Economist in the Monetary and Economic Department at the Bank for International Settlements, where he has published papers on the effects of unconventional monetary policy and monetary policy spillovers.

Prior to joining the BIS in 2012, he was a senior economist at the Bank of England, with positions in both the Monetary Analysis and Financial Stability directorates. Ryan holds a Ph.D. in economics from the University of Maryland, College Park. 


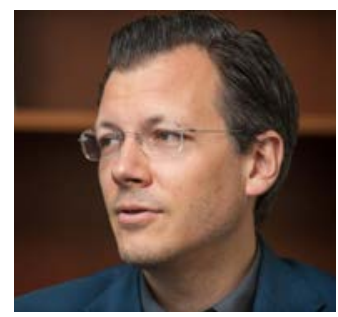

ULRICH BINDSEIL

Director General

Directorate General Market Operations

European Central Bank

Mr. Ulrich Bindseil has been the Director General of the ECB's Directorate General Market Operations since May 2012. Previously, he had been Deputy Director General, head of the ECB's Risk Management Division and the ECB's Liquidity Management Section. The ECB's DG Market Operations is responsible for implementing monetary policy (Eurosystem credit operations, collateral framework, asset purchase programmes, etc.) and for the management of the ECB's foreign reserves and investment portfolios. He chairs the ECB's Market Operations Committee, the ECB's Money Market Contact Group and the ECB's Bond Market Contact Group. He is a member of two BIS committees, the Markets Committee and the Committee on the Global Financial System (CGFS).

Mr. Bindseil has joined central banking in 1994, namely in the Economics Department of the Deutsche Bundesbank, after his Economics studies. His publications include: Monetary policy implementation (Oxford University Press, 2004); Risk Management for Central Banks and Other Public Investors (editor, together with F. González and E. Tabakis, Cambridge University Press, 2009); Monetary Policy Operations and the Financial System (Oxford University Press, 2014). 


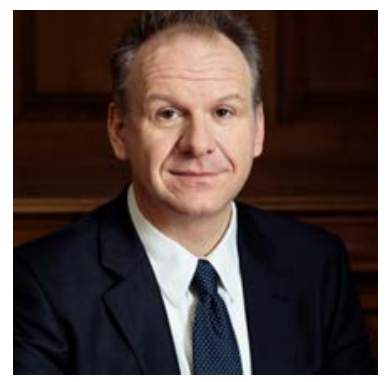

THOMAS MOSER

Alternate Member of the

Governing Board

Swiss National Bank

Dr. Thomas Moser concluded his university studies in 1997 with a Doctorate in Economics from the University of Zurich. From 1994 to 1996, he was employed as a Teaching and Research Assistant at the University of Zurich's Institute for Empirical Research in Economics, and from 1996 to 1999, as an Economist at the KOF Swiss Economic Institute (formerly Swiss Institute for Business Cycle Research) at ETH Zurich.

In 1999, he joined the Swiss National Bank (SNB) as a Senior Economist in the International Monetary Relations unit. He was in W ashington from 2001 to 2004, working first as Advisor to the Swiss Executive Director at the International Monetary Fund (IMF) and then, from 2002, as Senior Advisor. After returning to Switzerland in 2004, be took up a position as Assistant Director and Deputy Head of the International Research and Technical Assistance unit at the SNB in Zurich. From early May 2006 to the end of 2009, he was Executive Director of the IMF constituency in W ashington beaded by Switzerland.

The Federal Council appointed Dr. Moser Alternate Member of the Governing Board in Department I (Economic Affairs, International Affairs, Legal and Property Services, Secretariat General) with effect from the beginning of 2010.

Relevant affiliations in the past five years:

Member of the Board of Directors and the Compensation Committee of Orell Füssli Holding Ltd (since 2014). 


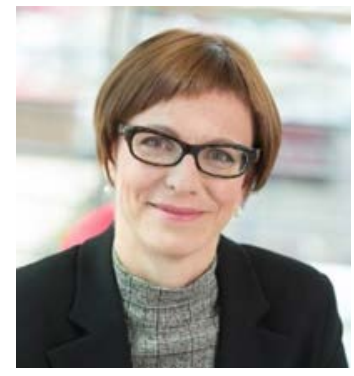

DANA HAJKOVA

Advisor to the Bank Board

Czech National Bank

Dr. Dana Hajkova, Ph.D., is an Adviser to the Bank Board in the Czech National Bank. A graduate from CERGE-EI Prague, she benefited from work experience in the $O E C D$, in the Czech National Bank, as well as in commercial banking, where she beld macroeconomist positions.

She is interested in research in monetary policy and its interaction with other macroeconomic policies, economic growth, and productivity. 


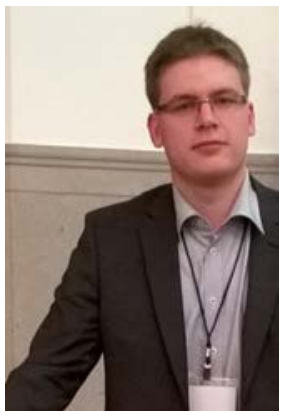

DANIEL FELCSER

Senior Analyst

Monetary Strategy Department

Magyar Nemzeti Bank

Mr. Daniel Felcser is a Senior Analyst in the Monetary Strategy Department at the Magyar Nemzeti Bank (National Bank of Hungary).

Mr. Felcser joined the Bank in 2008 as a member of the monetary policy team. The Department, among other responsibilities, prepares monetary policy analyses, conducts briefings in support of the Bank executive's participation in domestic and international policy meetings, and monitors international monetary policy developments.

He has co-authored research publications in the International Journal of Central Banking, the (Hungarian) Financial and Economic Review, the MNB Bulletin, the MNB Working Paper Series, and other occasional MNB publications. He holds an $M A$ in Economics from Corvinus University of Budapest. 


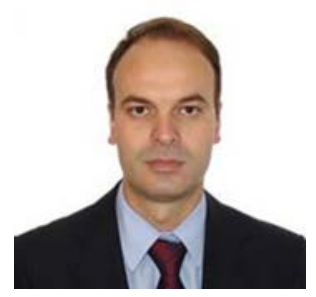

ERALD THEMELI

Director

Monetary Policy Department

Bank of Albania

Mr. Erald Themeli joined the Bank of Albania in 2000. After earning a Bachelor's Degree in Finance and Banking from the University of Tirana, he completed an MSc in European Economic Studies from the University of Tirana and an MSc in Financial Economics from the University of Exeter.

Throughout his employment at the Bo A, Mr. Themeli has worked at various positions in the Monetary Policy Department. Since October 2008, he has served as Director of the Monetary Policy Department.

Mr. Themeli is a member of the Advisory and Implementation Committee of Monetary Policy, of the FX Reserves Investment Committee, of the joint Bo A-MoF Debt and Liquidity Management Committee, etc..

His research interests are in the areas of monetary economics, monetary policy instruments, and macroeconomic projections and forecasting. 


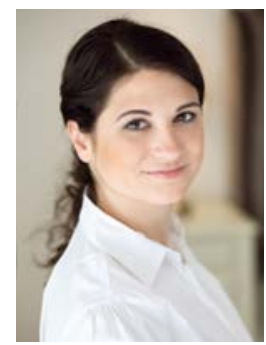

ISABELLA MODER

Economist

External Developments Division

European Central Bank

Ms. Isabella Moder has been working at the European Central Bank. (ECB) since 2015. As an Economist in the External Developments Division, she conducts research in the area of international macroeconomics. Additionally, she is in charge of the country desk. for Albania, Serbia, and Turkey.

Before joining the ECB, Ms. Moder worked in a similar position for the Oesterreichische Nationalbank (OeNB), and for a commercial bank, focusing on large infrastructural projects.

She holds a Master's Degree in Economics and a Bachelor's Degree in International Affairs, both obtained from the University of St. Gallen (Switzerland). 


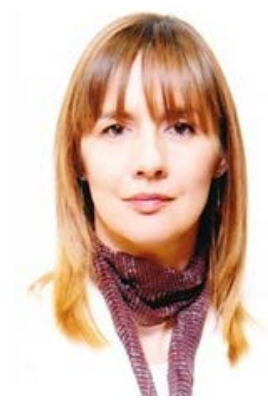

ANITA ANGELOVSKA BEZHOSKA

Vice Governor

National Bank of the Republic of Macedonia

Dr. Anita Angelouska-Bezhoska has 19 years of experience, mostly in the areas of monetary policy, macroeconomic policies in general, fiscal policy, and public finance management.

Currently she holds the position of Vice Governor of the National Bank of the Republic of Macedonia (NBRM), responsible for monetary policy, research, and statistics. She is also a member of the Governing Council of the NBRM and a Deputy Governor of the Republic of Macedonia on the Board of Governors of the International Monetary Fund. Before being appointed as a Vice Governor, she held the position of Chief Economist of the NBRM, involved in the area of design and implementation of the monetary policy, macroeconomic forecasting, analyses, and economic researches.

Dr. Angelovska-Bezhoska worked for the International Monetary Fund (IMF) in Washington as an Economist in the European Department and Fiscal Affairs Department for two years, when she was a member of several negotiating missions for programs between the $I M F$ and the member states, and was also engaged as an expert in the IMF's missions for providing technical assistance to its member states. As a leader of the task. force for establishment of the treasury system in Macedonia, and later on as Head of the Treasury at the Ministry of Finance, she participated in the process of reforming the public finance management system in the Republic of Macedonia, including establishment of a single treasury account, commitment control system, budget liquidity management, and development of the government securities market.

She was awarded by the Embassy of the United States in the Republic of Macedonia for her contribution to the development of the public finance system in the Republic of Macedonia. She also beld the position of State Secretary in the Ministry of Finance, responsible for coordinating the process of macroeconomic forecasting, planning and execution of the budget of the Republic of Macedonia, and for the relations with international financial institutions.

Moreover, she was a member of the Management Board of the Health Insurance Fund and the Deposit Insurance Fund of the Republic of Macedonia. She was a lecturer at the Center of Excellence in Finance in Ljubljana and at the Faculty of Business Economics and Management of the University American College in Skopje. She graduated in 1994, and received an MBA Degree from the Faculty of Economics in Skopje in 1997. She received her Doctorate from the Faculty of Economics in Ljubljana, Slovenia, in 2015. 


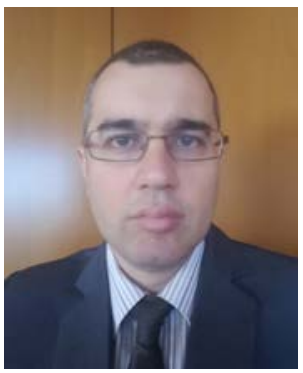

BRANISLAV ZOROJA

General Manager

Monetary Operations Department

National Bank of Serbia

Mr. Branislav Zoroja has been general manager of the Monetary Operations Department at National Bank of Serbia (NBS) since 2012. The Monetary Operations Department of NBS is in charge of monetary policy implementation, market intelligence and research, and public debt issues. Mr. Zoroja duties involve coordination, guidance, and control in implementation of monetary policy instruments and measures (open market operations, required reserves, standing facilities, and NBS foreign exchange interventions, including swap operations). Other duties relate to improvements of instrument design, guidance in research, cooperation with other departments, with state institutions, banks, international financial institutions, investors, and foreign central banks in order to raise the reputation of the NBS.

From 2002 to 2012, Mr. Zoroja held differentpositions at increasing level of seniority in the Monetary Operations Department of NBS (Senior Assistant in the Open Market Operations Division, Director of FX Market Division, and Deputy General Manager for the Monetary Operations Department).

Mr. Zoroja is a member of several working groups regarding budget liquidity, public debt issuance, and ISD A Master Agreement. He is playing a leading role in the context of the Serbia' euro integration effort, focusing on the field of "Monetary and Economic Policy". He contributed to the conclusion of the swap agreement between NBS and the People Bank of China, in order to improve economic cooperation between the two countries and to strengthen financial stability. He also contributed to promote foreign exchange hedging instruments through various initiatives.

In 2004, Mr. Zoroja received his $M A$ in Economics and Finance from the Faculty of Economics of the University of Belgrade. This followed is BSc. in Economics and Finance obtained in 2000 from the Faculty of Economics of the University of Belgrade, where he majored in finance, banking, and insurance. 


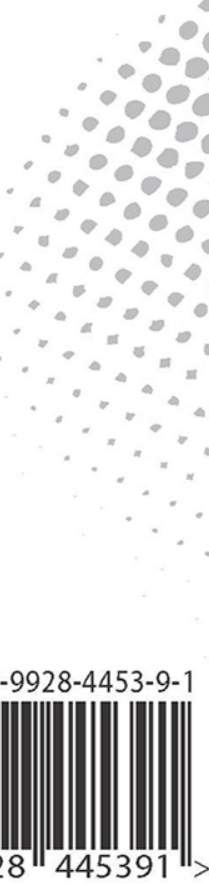

